

\section{DISCLAIMER}

This report was prepared as an account of work sponsored by an agency of the United States Government. Neither the United States Government nor any agency Thereof, nor any of their employees, makes any warranty, express or implied, or assumes any legal liability or responsibility for the accuracy, completeness, or usefulness of any information, apparatus, product, or process disclosed, or represents that its use would not infringe privately owned rights. Reference herein to any specific commercial product, process, or service by trade name, trademark, manufacturer, or otherwise does not necessarily constitute or imply its endorsement, recommendation, or favoring by the United States Government or any agency thereof. The views and opinions of authors expressed herein do not necessarily state or reflect those of the United States Government or any agency thereof. 


\section{DISCLAIMER}

Portions of this document may be illegible in electronic image products. Images are produced from the best available original document. 


\section{NOTICE}

This report was prepared as an account of work sponsored by the United States Government. Neither the United States nor the United States Department of Energy, nor any of their employees, nor any of their contractors, subcontractors, or their employees, makes any warranty, express or implied, or assumes any legal liability or responsibility for the accuracy, completeness or usefulness of any information, apparatus, product or process disclosed, or represents that its use would not infringe privately owned rights.

This report has been reproduced directly from the best available copy.

Available from the National Technical Information Service, U.S. Department of Commerce, Springfield, Virginia 22161.

Price: Paper Copy $\$ 9.25$

Microfiche $\$ 3.00$ 


\section{GEOPRESSURED GEOTHERMAL FAIRWAY EVALUATION AND TEST-WELL SITE LOCATION FRIO FORMATION, TEXAS GULF COAST}

By

D. G. Bebout

R. G. Loucks

A. R. Gregory

Research Assistants
V. J. Gavenda
W. M. Haggard
H. J. Han
M. G. Moseley
J. E. Loocke
P. E. Luttrell
D. R. Prezbindowski
M. E. Rusk
J. H. SeO

This seport whs prepured 25 in eccount of work sponsored by the United States Govemment. Neither the United States nor the United States Departson of their Energy, nor any of their omployecs, nor ary of theikes contractors, mubcontractors, or their enployen, makes any warrenty, express or implied, or asumes any ley liability or responsibility for the sccuracy, completenes or wefulness of any th formation, appantus, product or process disclosed, of represents that the use would not infringe privately owned rights.

\section{MASTER}

Prepared for

The U.S. Department of Energy. Division of Geothermal Energy

in partial fulfillment for

CONTRACT NO. AT-E(40-1)-4891 (EY-76-S-05-4891)

January 1978

\section{Bureau of Economic Geology}

The University of Texas at Austin

W. L. Fisher, Director 


\section{CONTENTS}

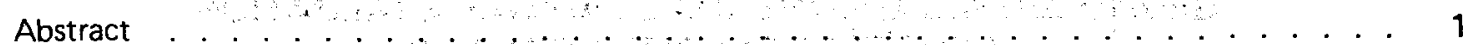

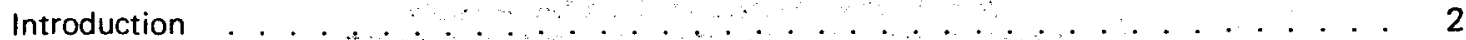

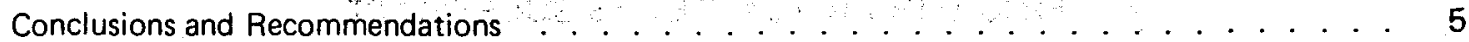

Tertiary Depositional and Structural Style . . . . . . . . . . . . . . . . . . . . . . . . . 9

Regional Geologic Investigation Based on Grid of Frio Correlation Sections . . . . . . . . . . . 15

Interpretation of Depositional Environments from Sandstone Percent Maps . . . . . . . . . . 20

Hidalgo Fairway . . . . . . . . . . . . . . . . . . . . . . . . . . . . . . . . . . . 28

The Armstrong Fairway . . . . . . . . . . . . . . . . . . . . . . . . . . . . . . . . 32

The Corpus Christi Fairway . . . . . . . . . . . . . . . . . . . . . . . . . . . . . . 36

Matagorda Fairways . . . . . . . . . . . . . . . . . . . . . . . . . . . . . . . 41

Brazoria Fairway-Structure . . . . . . . . . . . . . . . . . . . . . . . . . . . . . . 46

Brazoria Fairway-Depositional Style . . . . . . . . . . . . . . . . . . . ... . . . . 49

Sandstone Consolidation History - The Key to Origin of Porosity and Permeability . . . . . . . 55

Summary .. . . . . . . . . . . . . . . . . . . . . . . .......... . 59

Vertical Distribution of Depositional Sequences Within A Single Depositional Episode _. . . . 63

Areal Distribution of Lobate Deltas _. . . . . . . . . . . . . . . . . . . . . . . . . . 70

Porosity and Permeability-Core Analysis . . . . . . . . . . . . . . . . . . . . . . . . . 78

Permeability-Well Production Flow Tests . . . . . . . . . . . . . . . . . . . . . . . . . 85

Permeability-Reservoir Fluid Deliverability . . . . . . . . . . . . . . . . . . . . . . . . 90

Salinity and Methane Content . . . . . . . . . . . . . . . . . . . . . . . . . . . . 92

Temperature and Pressure _. . . . . . . . . . . . . . . . . . . . . . . . . . . . . . . . . . . . . 96

Reservoir Pressure Decline and Hydrocarbon Production Histories . . . . . . . . . . . . . . . 99

Disposal of Geothermal Waste Water . . . . . . . . . . . . . . . . . . . . . . . . . . 106

Predicted Reservoir Performance . . . . . . . . . . . . . . . . . . . . . . . . . . . . 109

Acknowledgments . . . . . . . . . . . . . . . . . . . . . . . . . . . . 117

References . . . . . . . . . . . . . . . . . . . . . . . . . . . . . . . . 118

Appendix-List of Wells in the Frio Formation . . . . . . . . . . . . . . . . . . . . . . . . 120 


\title{
GEOPRESSURED GEOTHERMAL FAIRWAY EVALUATION AND TEST-WELL SITE LOCATION \\ FRIO FORMATION, TEXAS GULF COAST
}

\author{
D. G. Bebout, R. G. Loucks, A. R. Gregory
}

\section{Abstract}

Tertiary strata of the Texas Gulf Coast comprise a number of terrigenous depositional wedges, some of which thicken abruptly at their downdip ends as a result of contemporaneous movement of growth faults and underlying salt. The Frio Formation, one of these wedges, has been studied regionally by means of a grid of correlation cross sections aided by micropaleontological control. By means of these sections, the Frio was subdivided into six map units; maps of sandstone distribution within these units delineate principal elongate sandstone trends parallel to the Gulf Coast composed of deltaic, barrier-bar, and strandplain sandstones.

These broad regional studies, followed by detailed local investigations, were pursued in order to delineate prospective areas for production of geopressured geothermal energy. A prospective area must meet the following minimum requirements: reservoir volume of 3 cubic miles, minimum permeability of 20 millidarcys (md), and fluid temperatures of $300^{\circ} \mathrm{F}$. Several geothermal fairways were identified as a result of this Frio study.

The Hidalgo Fairway is located in Hidalgo, Cameron, and Willacy Counties, and contains many thick, laterally-extensive deltaic sandstone bodies with fluid temperatures greater than $300^{\circ} \mathrm{F}$, but with extremely low permeabilities. The Armstrong Fairway, located in Kenedy County, contains a number of thick sandstones which extend over an area of 50 square miles and have probable core permeabilities of 20 millidarcys, but fluid temperatures of less than $300^{\circ} \mathrm{F}$. The Corpus Christi Fairway, located primarily in Nueces County, contains sandstones with temperatures greater than $300^{\circ} \mathrm{F}$, but the sandstone beds are thin and are limited in lateral extent and low in permeability. The Matagorda Fairways contain sandstones which have high fluid temperatures but are thin and extremely limited in area. In the Brazoria Fairway the section deeper than 13,500 feet contains several hundred feet of sandstone with fluid temperatures greater than $300^{\circ} \mathrm{F}$ and permeabilities between 40 and 60 millidarcys. The major limiting factor in each of the above fairways is the scarcity of adequate permeability in reservoirs with fluid temperatures of $300^{\circ} \mathrm{F}$. Only the Brazoria Fairway meets all of the specifications for a geothermal prospect.

In the Brazoria Fairway, located in Brazoria and Galveston Counties, contemporaneous deltaic sedimentation, movement along growth faults, and mobilization of deep salt into domes resulted in the accumulation of several hundred feet of sandstone with fluid temperatures greater than $300^{\circ} \mathrm{F}$. Permeabilities within these reservoirs are greater than 20 millidarcys; this high permeability is related to secondary leached porosity; which developed in the moderate to deep sübsurface.

A prospective geothermal well site has been located within the Austin Bayou Prospect, Brazoria Fairway, which will have 250 to 350 feet of reservoir sandstone with core permeabilities between 40 and 60 millidarcys, and fluid temperatures from $300^{\circ}$ to $350^{\circ} \mathrm{F}$. The sandstone-shale section within the Austin Bayou area is represented by seven progradational depositional sequences. Each sequence is composed of a gradational vertical succession, characterized by lowporosity prodelta and distal delta-front shale and sandstone at the base, to porous distributary-mouth bar and delta-plain sandstone and shale at the top. The older depositional sequences represent the distal half of a lobate delta, and the later events represent the entire deltaic complex.

Effective gas permeabilities, determined from production flow tests, are estimated to range from 1 to 6 millidarcys, and absolute permeabilities lie between 2 and 10 millidarcys for selected wells in the Chocolate Bayou field, Brazoria County, Texas. In a reservoir with a permeability of 10 millidarcys, a sandstone thickness of 380 feet, and a drawdown pressure of 5,000 psia (pounds per square inch absolute), a flow rate of 40,000 barrels of water per day can be 
achieved. Salinity of this water will range from 40,000 to 80,000 ppm (parts per million), and methane content may range from 25 to 45 cubic feet per barrel. The average geothermal gradient is $1.8^{\circ} \mathrm{F}$ per 100 feet, and reservoir fluid pressures lie between 0.465 and 0.98 psia per foot for depths below 10,000 feet in the Chocolate Bayou field.

In summary, detailed geological, geophysical, and engineering studies conducted on the Frio Formation have delineated a geothermal test well site in the Austin Bayou Prospect which extends over an area of 60 square miles. A total of $\mathbf{8 0 0}$ to $\mathbf{9 0 0}$ feet of sandstone will occur between the depths of 13,500 and 16,500 feet. At least 30 percent of the sand will have core permeabilities of 20 to 60 millidarcys. Temperature at the top of the sandstone section will be $300^{\circ} \mathrm{F}$. Water, produced at a rate of 20,000 to 40,000 barrels per day, will probably have to be disposed of by injection into shallower sandstone reservoirs.

More than 10. billion barrels of water are in place in these sandstone reservoirs of the Austin Bayou Prospect; there should be approximately 400 billion cubic feet of methane in solution in this water. Only 10 percent of the water and methane ( 1 billion barrels of water and 40 billion cubic feet of methane) will be produced without reinjection of the waste water into the producing formation. Reservoir simulation studies indicate that 90 percent of the methane can be produced with reinjection.

\section{Introduction}

For more than $2 \frac{1}{2}$ years the Bureau of Economic Geology and the Department of Petroleum Engineering, University of Texas at Austin, have been conducting a study to evaluate production of potential geothermal energy from the geopressured Tertiary sandstones along the Texas Gulf Coast. The objective of the geothermal project is to locate several prospective reservoirs which will meet the following specifications: reservoir volume of 3 cubic miles, minimum permeability of 20 millidarcys, ${ }^{\prime}$ and fluid tem-

\footnotetext{
' It should be emphasized that this permeability is to salt water at subsurface pressures and temperatures. Core-analysis permeabilities referred to in this report, on the other hand, are based on air in unconfined cores at surface pressures and temperatures. Subsurface permeabilities are expected to be considerably lower than equivalent core-analysis permeabilities.
}

perature of $300^{\circ} \mathrm{F}$ or greater. Water to be produced is expected to have a salinity of 20,000 to $80,000 \mathrm{ppm}$ total dissolved solids and to be saturated with methane (40 to 50 cubic feet per barrel of water). The initial bottom-hole pressure will be greater than 10,000 psi. A broad-based survey indicated that three formations-the Frio, Vicksburg, and Wilcox-have potential to meet these specifications (figs. 1 and 2 ).

A successful geothermal well should produce hot water at a rate of 20,000 to 40,000 barrels per day. Thermal and physical energy will be used to run turbines to produce electricity at the site, and the methane will be stripped off and routinely processed as natural gas. Salinity of the water is expected to be too high to use on the surface for agricultural purposes and probably will have to be reinjected through disposal wells into a shallower reservoir.

This investigation was subdivided into two major phases: regional resource assessment and detailed site selection. The objective of the regional studies was to outline geothermal fairways in which thick sandstone bodies have fluid temperatures higher than $300^{\circ} \mathrm{F}$. Actually, $250^{\circ} \mathrm{F}$ uncorrected bottom-hole temperatures recorded on well logs were mapped for convenience; because bottomhole conditions were not stable at the time of the recordings, the $250^{\circ} \mathrm{F}$ recording will correct to near $300^{\circ} \mathrm{F}$. Subsurface control was based on a grid of wells spaced 5 to 10 miles apart. Fairways resulting from the regional study, then, became areas which warranted additional work through the site selection phase in order to determine reservoir size, relationship to major and minor growth faults, porosity and permeability, and nature of the porosity (diagenetic fabric). From this site selection study favorable sites for the location of geothermal wells were identified.

Regional assessment and site selection studies of the Frio Formation have been completed, and reports summarizing the regional studies of this formation along the Lower, Middle, and Upper Texas Gulf Coast have been published earlier by the Bureau of Economic Geology (Bebout, Dorfman, and Agagu, 1975; Bebout, Agagu, and Dorfman, 1975; and Bebout, Loucks, Bosch, and Dorfman, 1976) (fig. 3). More detailed information concerning the regional distribution of Frio sandstones is available from these reports; a summary is included in this report. Results of the detailed site selection study of the Austin Bayou Prospect are also described here. 


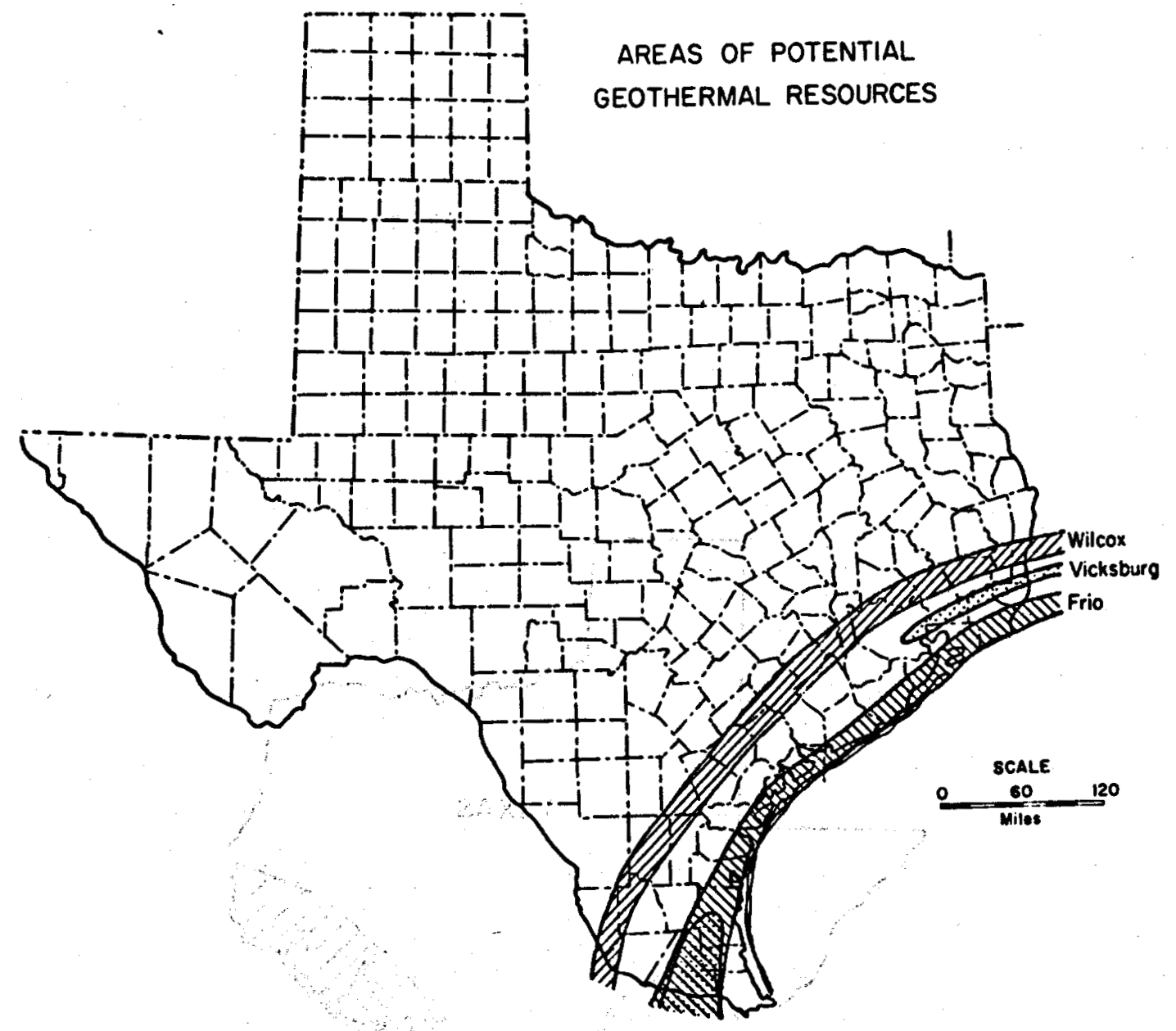

Figure 1. Geothermal corridors of potentlal fairways (Bebout, 1976).

\section{CENOZOIC - TEXAS GULF COAST}

\begin{tabular}{|c|c|c|}
\hline AGE & SERIES & GROUP/FORMATION \\
\hline Quaternary & $\begin{array}{l}\text { Recent } \\
\text { Pleistocene }\end{array}$ & $\begin{array}{l}\text { Undifferentiated } \\
\text { Houston }\end{array}$ \\
\hline \multirow{7}{*}{ Tertiary } & Pliocene & Goliad \\
\hline & \multirow{2}{*}{ Miocene } & Fleming \\
\hline & & Anahuac \\
\hline & \multicolumn{2}{|l|}{ Oligocene } \\
\hline & \multirow[b]{2}{*}{ Eocene } & Jackson \\
\hline & & Claiborne \\
\hline & & Midway \\
\hline
\end{tabular}

Figure 2. Tertiary formations, Gulf Coast of Texas. Prospective formations are shown with stipple and line patterns which correspond with those in figure 1 . 


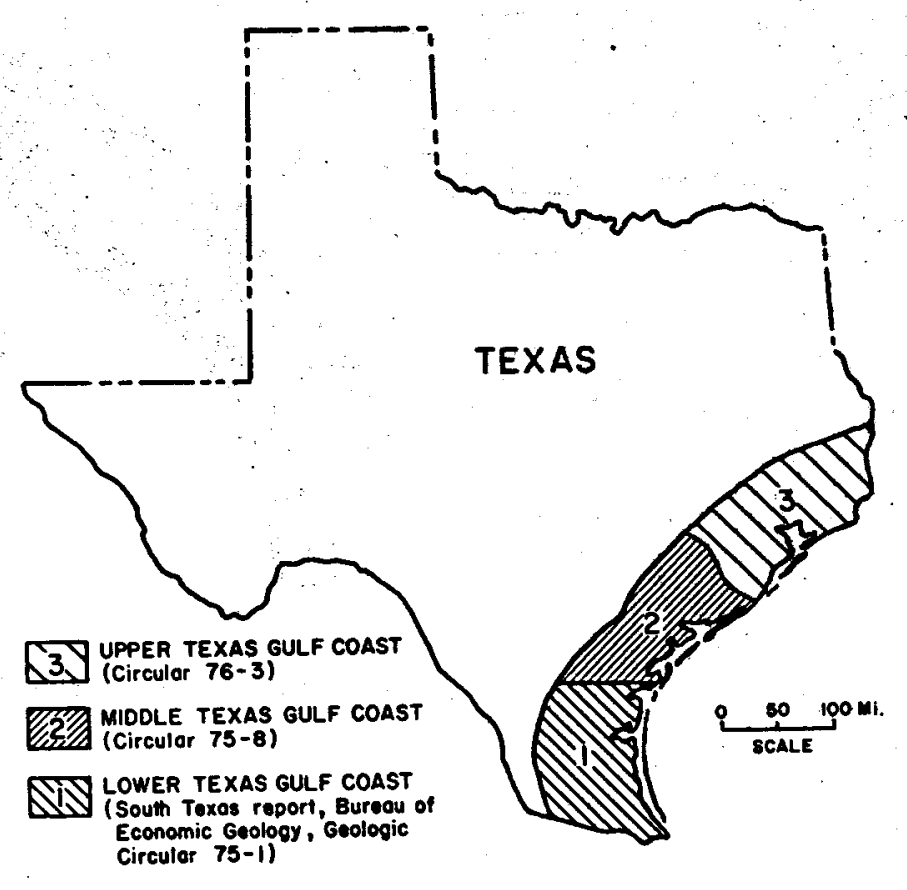

Figure 3. Areas of previously published Frio studies. 


\section{Conclusions and Recommendations}

Broad regional and detailed local subsurface studies have resulted in the delineation of a prospect area, the Austin Bayou Prospect of the Brazoria Fairway, which meets the minimum requirements for a geopressured geothermal test well.

Regional studies of sandstone distribution within the Frio Formation have outlined areas of thick sandstone accumulation. In general, the Frio consists of a gulfwardthickening and dipping wedge of sandstone and shale. A high-sand depocenter consisting of deltaic, strandplain, and barrier-bar sandstone facies occurs near the center of the wedge. Thin, fluvial-plain sandstones occur within a dominantly shale section updip of this depocenter. Sandstone bodies downdip in the shelf and prodelta environments are also thin and occur in a thick shale section. Sandstone distribution maps combined with isothermal maps permit the delineation of areas in which thick sandstone bodies are expected to contain fluid temperatures greater than $300^{\circ} \mathrm{F}$. These areas, termed "geothermal fairways," have been studied in detail in order to determine their potential for producing geopressured geothermal energy. Five geothermal fairways have been identified along the Frio trend-Hidalgo, Armstrong, Corpus Christi, Matagorda, and Brazoria (fig. 4).

Three depositional-structural models represent the five fairways (fig. 4). The most simple model, Model.I, is developed in the Corpus Christi and Matagorda Fairways along the Middle Texas Gulf Coast. Massive sandstones occur between 6,000 and 9,000 feet below sea level; the top of the zone of geopressure occurs just beneath these sandstones where the subsurface fluid temperature is approximately $200^{\circ} \mathrm{F}$. Thin tongues of sandstone reach gulfward from the main sand depocenter and become increasingly more thinly bedded and finer grained. Fluid temperature reaches $300^{\circ} \mathrm{F}$ near the distal end of these tongues; growth faults which developed later during post-Frio deposition separate these distal sand bodies from their updip equivalents. The potential geothermal reservoirs of the Corpus Christi and Matagorda Fairways are inferred to be distal sandstones.

The Hidalgo and Armstrong Fairways along the Lower Texas Gulf Coast are represented by Model II (fig. 4). During deposition of thick deltaic sands of the lower part of the section, contemporaneous growth faults developed which allowed for the vertical accumulation of thick sands on the gulfward side of the faults. As a result of rapid downward movement along the faults, the sandstones subsided into the deep subsurface. Top of geopressure occurs near the top of the thick deltaic wedge, and the fluid temperature is approximately $200^{\circ} \mathrm{F}$. Thick sandstone bodies occur several thousand feet below the top of geopressure and, in many cases, contain fluid temperatures in excess of $300^{\circ} \mathrm{F}$. The Hidalgo and Armstrong Fairways both contain thick deltaic sandstone reservoirs of this type.

The Brazoria Fairway along the Upper Texas Gulf Coast is represented by Model III (fig. 4), in which extensive progradation occurred during deposition of the lower part of the formation, and large quantities of sand were transported far gulfward of the normal trend of main sand deposition. Thick deltaic sands accumulated in a large salt-withdrawal basin bounded on the updip side by growth faults which developed contemporaneously with deposition. Fluid temperatures within this thick sandstone mass are higher than $300^{\circ} \mathrm{F}$. After deposition of this lower progradational part of the section, a transgression of the shoreline caused the main sand depocenter to shift updip, where progradation resumed. However, the upper main sand trend of the Frio never again reached gulfward to the position of the lower depocenter. Top of geopressure occurs just beneath these updip massive sandstones where the fluid temperature is approximately $200^{\circ} \mathrm{F}$. The reservoir sandstones of the Brazoria Fairway are deltaic in origin and accumulated on the downdip side of growth faults initiated by salt movement.

The above models illustrate that reservoirs of adequate sand volume and high fluid temperature occur in at least two fairways, Hidalgo and Brazoria. However, permeability is a third major limiting factor which must be considered. Along the Lower Texas Gulf Coast from Aransas County south to the Rio Grande, very low permeability has been recognized for many years in sandstones occurring deeper than 12,000 feet. Sandstones in the Corpus Christi Fairway have 
recorded sidewall-core permeabilities ranging from 1.2 to 14.0 millidarcys at depths greater than 14,000 feet; sidewall-core permeabilities are known to be greater than the core permeability. In the Armstrong Fairway, analyses of cores from deeper than 17,000 feet exhibit permeabilities that range from 0.0 to 73.0 millidarcys; core is not available from the shallower reservoir of this fairway, but cores from nearby fields indicate that permeability is very low at the shallower depth as well. In the Hidalgo Fairway, thousands of core analyses show average permeability of slightly greater than 1 millidarcy. In contrast, to the north in the Matagorda and Brazoria Fairways, permeability is considerably higher and, in many sandstones, it ranges from the tens to hundreds of millidarcys. Because of the high permeability, in addition to the thick sandstone and high temperature, the Brazoria Fairway is considered a prospective geothermal fairway, and the Austin Bayou Prospect has been located within this area.

Detailed geological, geophysical, and engineering studies conducted in Austin Bayou Prospect have delineated a geothermal test well site (fig. 5). These studies indicate that the top of the sand section will occur at a depth of 13,500 feet, and the base, at 16,500 feet. A total of 800 to 900 feet of sandstone should occur in this section of 3,000 feet (at least 30 percent of the sand will have core permeabilities of 20 to 60 millidarcys). Temperature at the top of the sand section will be $300^{\circ} \mathrm{F}$. The entire prospect extends over an area of 60 square miles; however, information about the depositional environments in which these sandstones were deposited indicates that each individual sandstone should not be expected to be continuous for more than 2 miles in a strike direction.

The test well should penetrate 840 feet of prospective reservoir sandstone. Average porosity of 20 percent or higher is predicted for 250 feet of the sandstone and 5 to 20 percent for the remainder. Provided that a maximum drainage area of 16 square miles is present and that all pore space is filled with water, the aquifer will contain more than 10 billion barrels of water. The total resource should be more than 400 billion cubic feet of methane in place. 

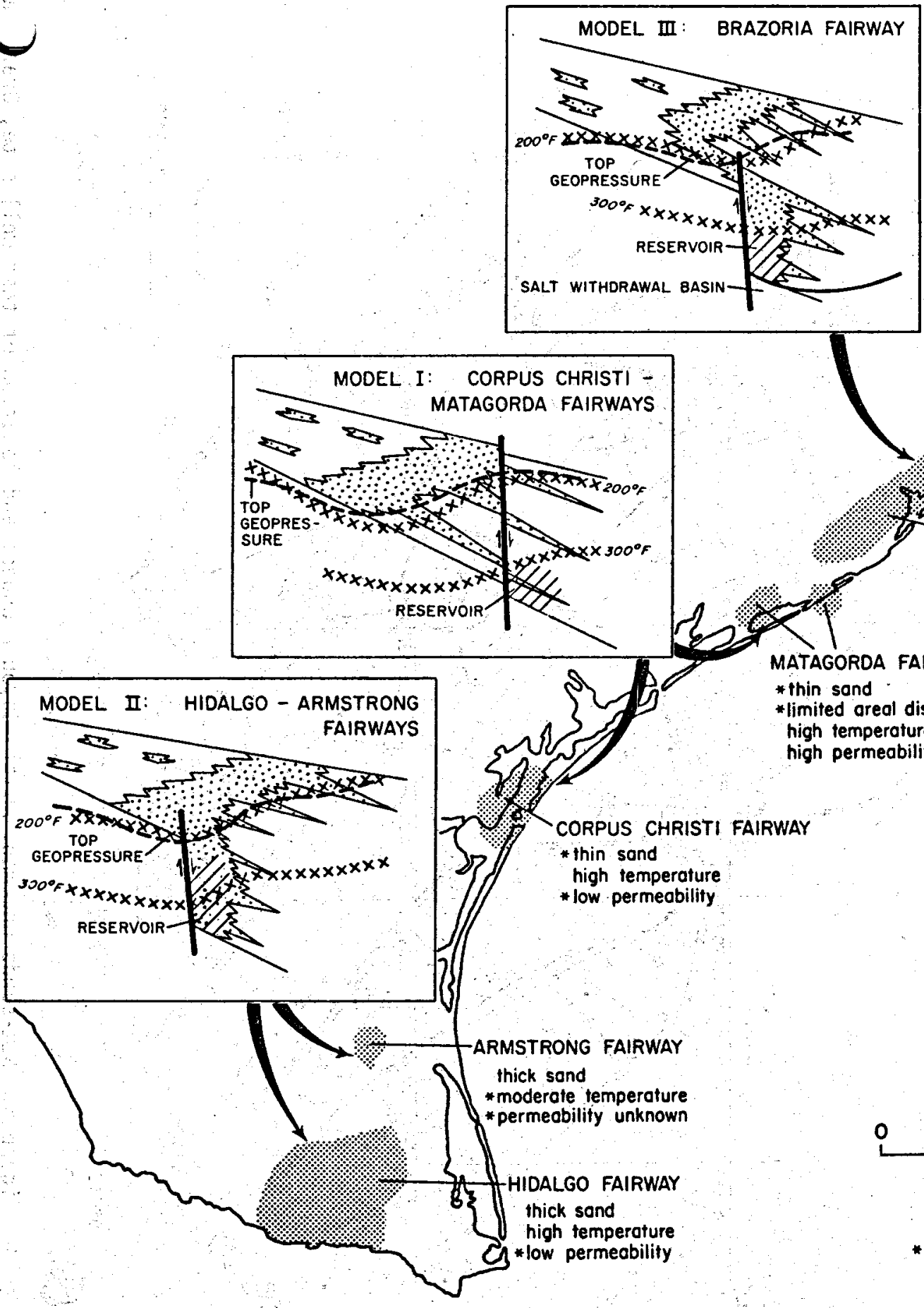

\section{MATAGORDA FAIRWAYS \\ * thin sand \\ * limited areal distribution \\ high temperoture \\ high permeability}

BRAZORIA FAIRWAY

thick sand

high temperature

high permeability

Figure 4. Frio geothermal fairways, depositional models, and reservoir quality. For actual examples of these models see figures 13 (Model II), 14 (Model I), and 15. (Model III). 


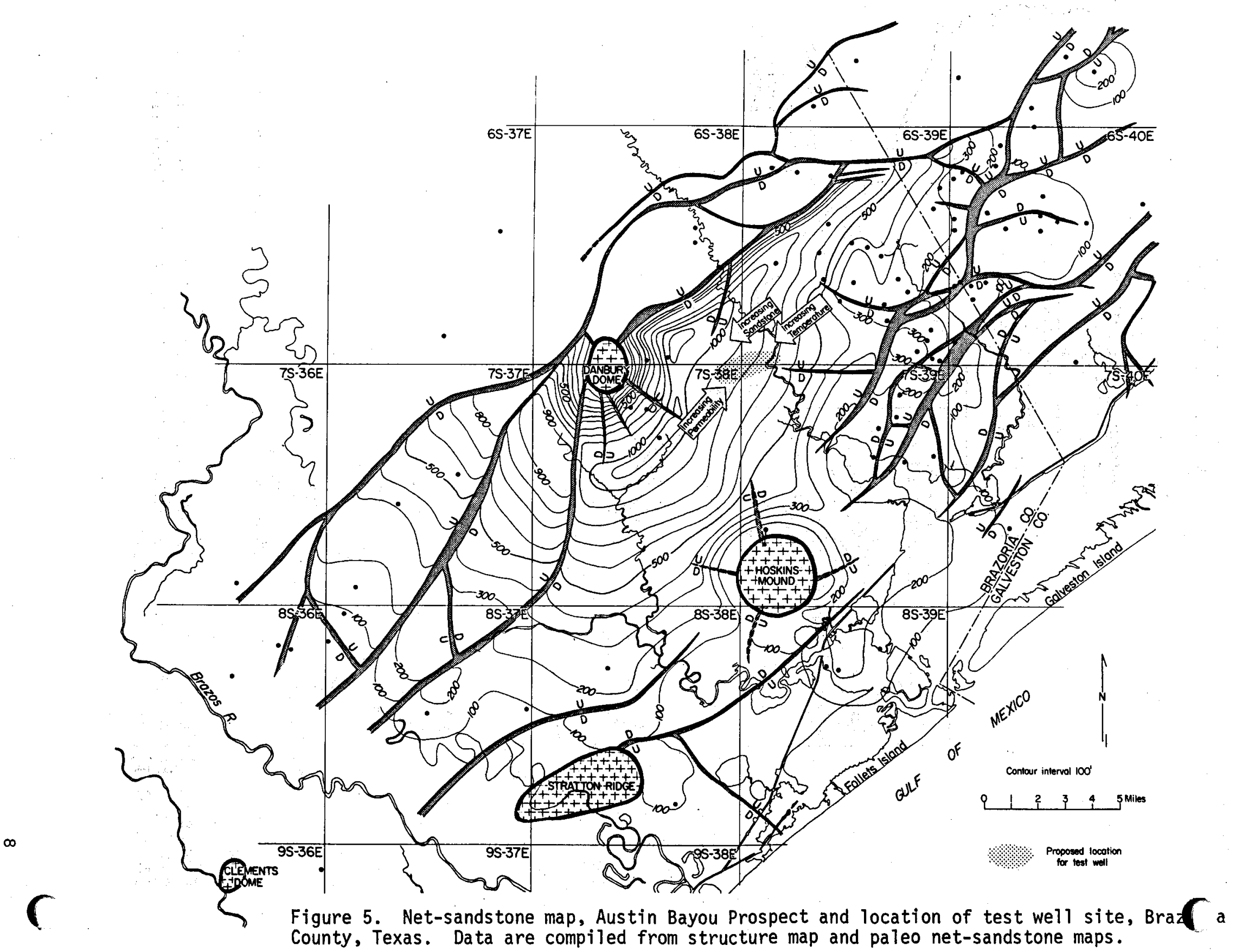




\section{Tertiary Depositional and Structural Style}

Tertiary strata of the Texas Gulf Coast comprise a number of terrigenous depositional wedges, some of which thicken abruptly at their downdip ends as a result of contemporaneous movement of growth faults or underlying salt or both.

During the Tertiary Period large quantities of sand and mud were transported across a broad fluvial plain and were deposited along the margins of the Gulf of Mexico. These sediments accumulated in the form of a number of wedges which thicken and dip gulfward (fig. 6). The overall trend is one of gulfward progradation so that each younger sedimentary wedge is shifted basinward of the previous wedge. Large growth fault systems formed near the downdip edge of each wedge within the area of maximum deposition (fig. 7). Faults developed as a result of rapid loading of large quantities of sand and mud on thick, low-density shale of previously deposited wedges. Deeper, thick Jurassic salt was also mobilized into a series of ridges and troughs because of this loading; linear trends of salt domes resulted. Movement of growth faults provided space for the accumulation of abnormally thick sections of sand and mud and also for isolation of porous downdip sandstones from porous updip sandstones. Because of this isolation, fluids within the sandstone reservoir were trapped, and on further loading and burial, geopressured reservoirs were developed (Bruce, 1973).

At least eight of these sandstone-shale wedges are recognized along the Texas Gulf Coast (Hardin, 1961). Each wedge is com- posed of sand and mud which was transported across a broad fluvial plain and either deposited in deltaic complexes or reworked by marine processes into strandplains and barrier bars. The Frio Formation is one of the thickest of these wedges. Consequently, the Frio is very similar to both the underlying and overlying wedges. Because of this similarity, identification in many cases is dependent upon the recognition of marker foraminifers. The Frio Formation contains a number of diagnostic foraminifers (fig. 8), and the base of the formation is identified by the occurrence of Textularia warreni, and the top, by Marginulina vaginata.

The time-equivalent strata of the subsurface Frio Formation are sandstone, shale, and volcanic ash of the outcropping $\mathrm{Ca}$ tahoula Formation. Catahoula strata are less than 500 feet thick and occur a few hundred feet above sea level (figs. 9 and 10). Outcropping Catahoula and shallow subsurface Frio deposits (down to 3,000 feet below surface) are the targets for extensive uranium exploration (Galloway, 1977). The Frio of intermediate depths (down to 10,000 feet) has produced a large proportion of the Texas Gulf Coast oil and gas, and the deep sandstones (deeper than 13,000 feet) are being studied as potential geopressured geothermal reservoirs. 


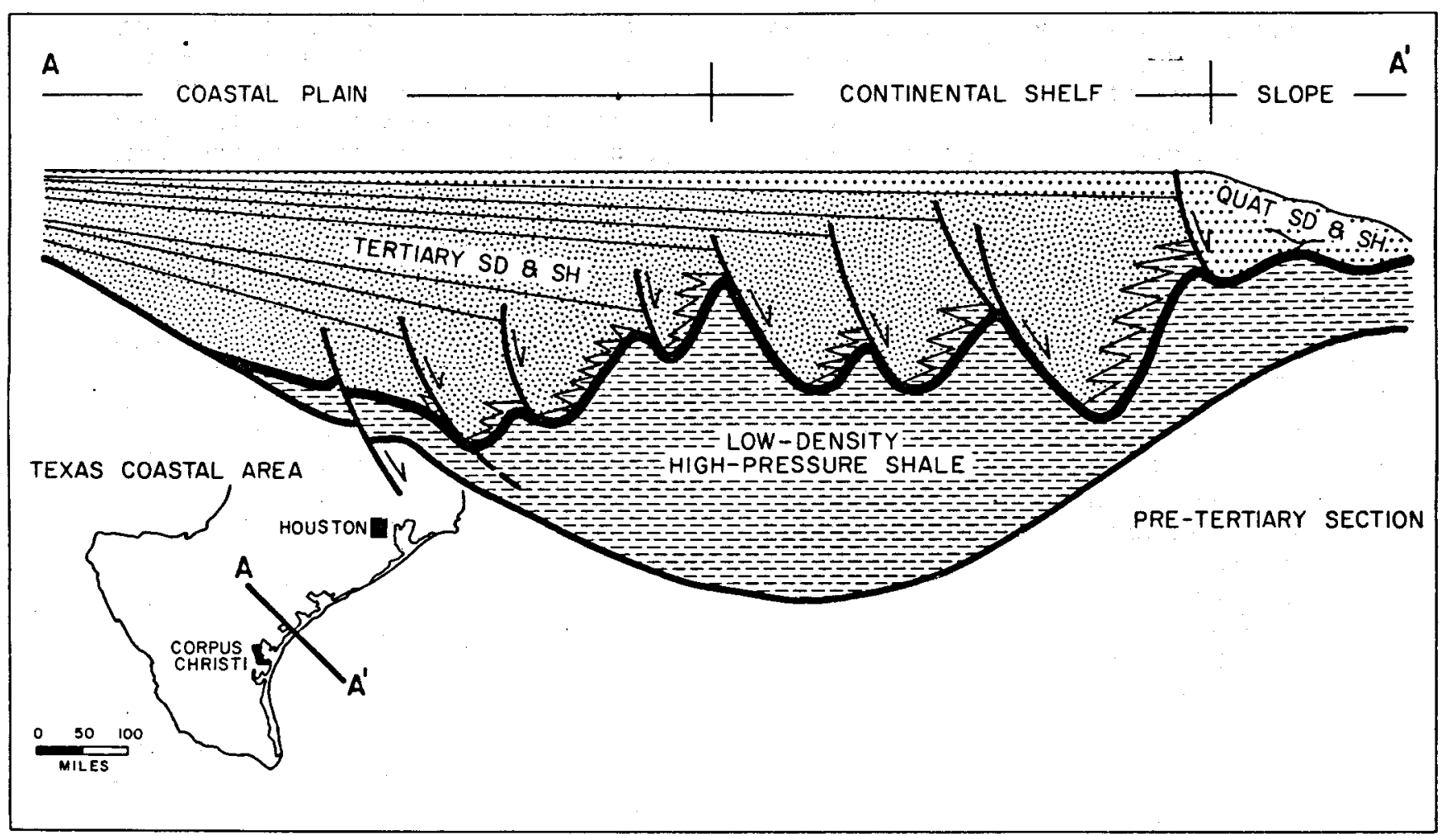

Figure 6. Depositional style of Tertiary strata along the Texas Gulf Coast (Bruce, 1973). 

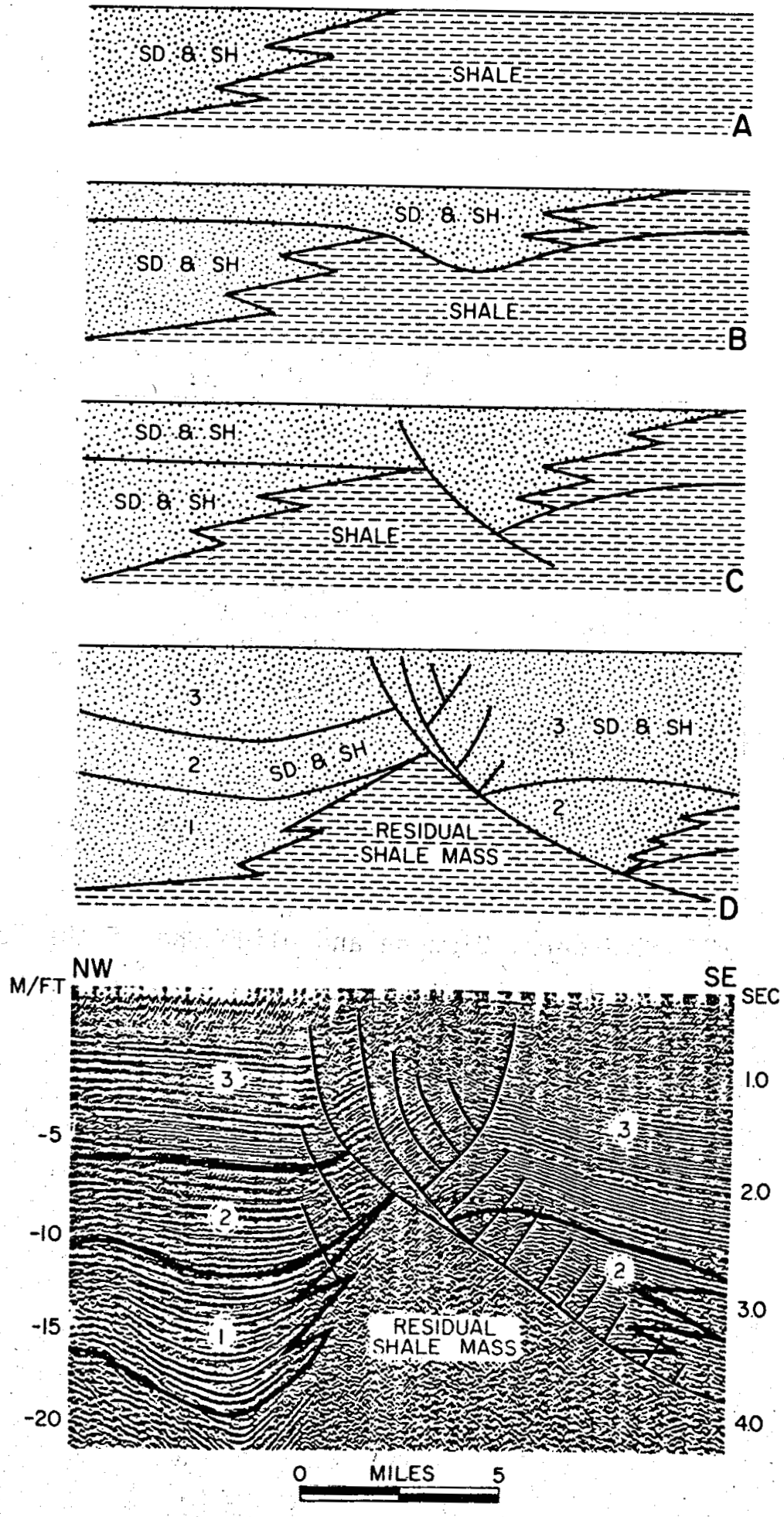

Figure 7. Growth fault development interpreted from a seismic section (Bruce, 1973). 


\begin{tabular}{|l|l|l|}
\hline SERIES & GROUP/FORMATION & \\
\hline Miocene & Anahuac & $\begin{array}{l}\text { Discorbis nomada } \\
\text { Heterostegina texana }\end{array}$ \\
\hline Oligocene & Frio & $\begin{array}{l}\text { Marginulina vaginata } \\
\text { Cibicides hazzardi } \\
\text { Nonion struma } \\
\text { Nodosaria blanpiedi } \\
\text { Textularia mississippiensis } \\
\text { Anomalia bilateralis }\end{array}$ \\
\hline & Vicksburg & \begin{tabular}{l} 
Textularia warreni \\
\hline
\end{tabular} \\
\hline
\end{tabular}

Figure 8. Foraminifer markers, Miocene and 0ligocene of the Texas Gulf Coast. 


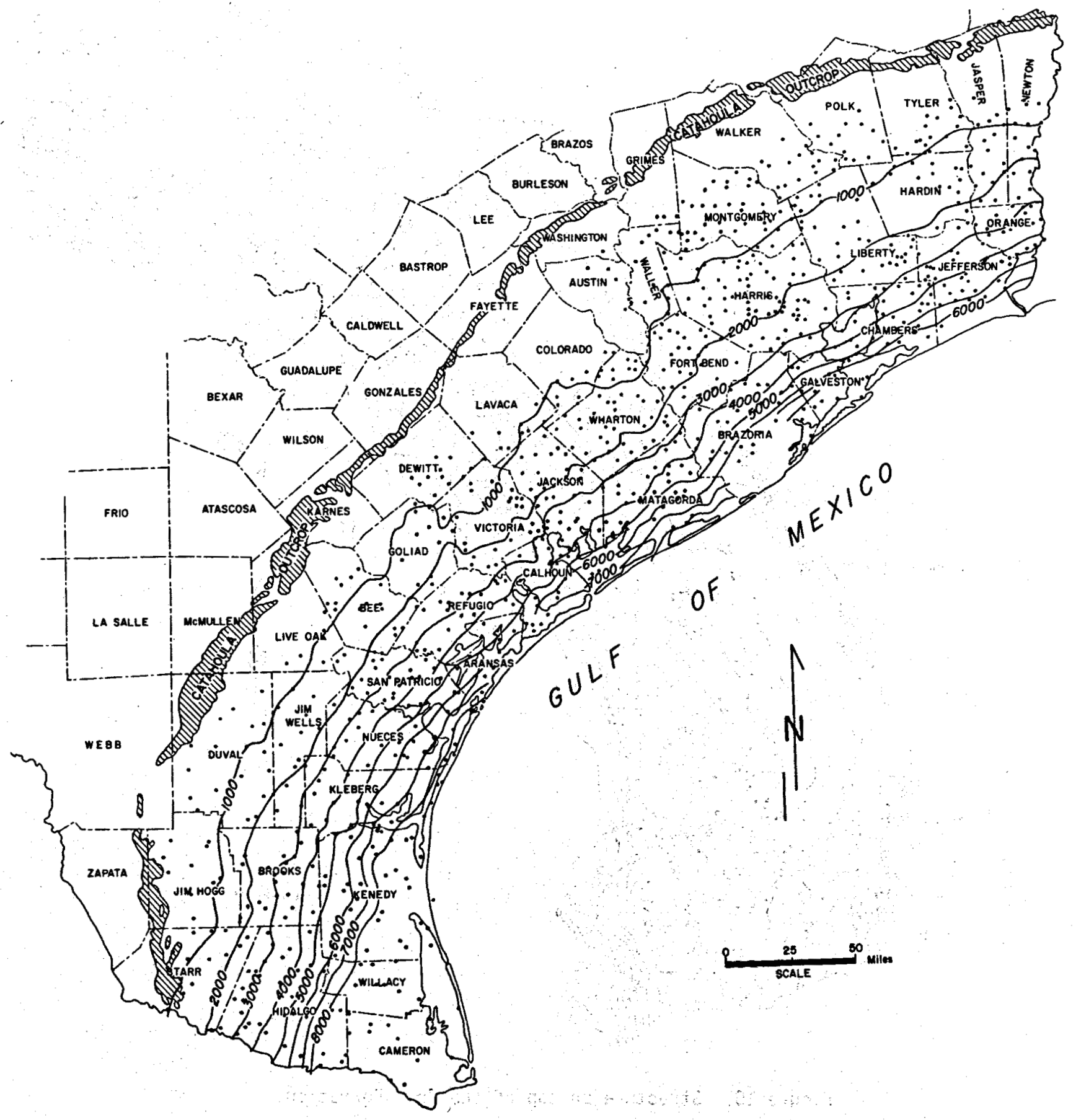

Figure 9. Total thickness, Frio Formation, Texas Gulf Coast. 


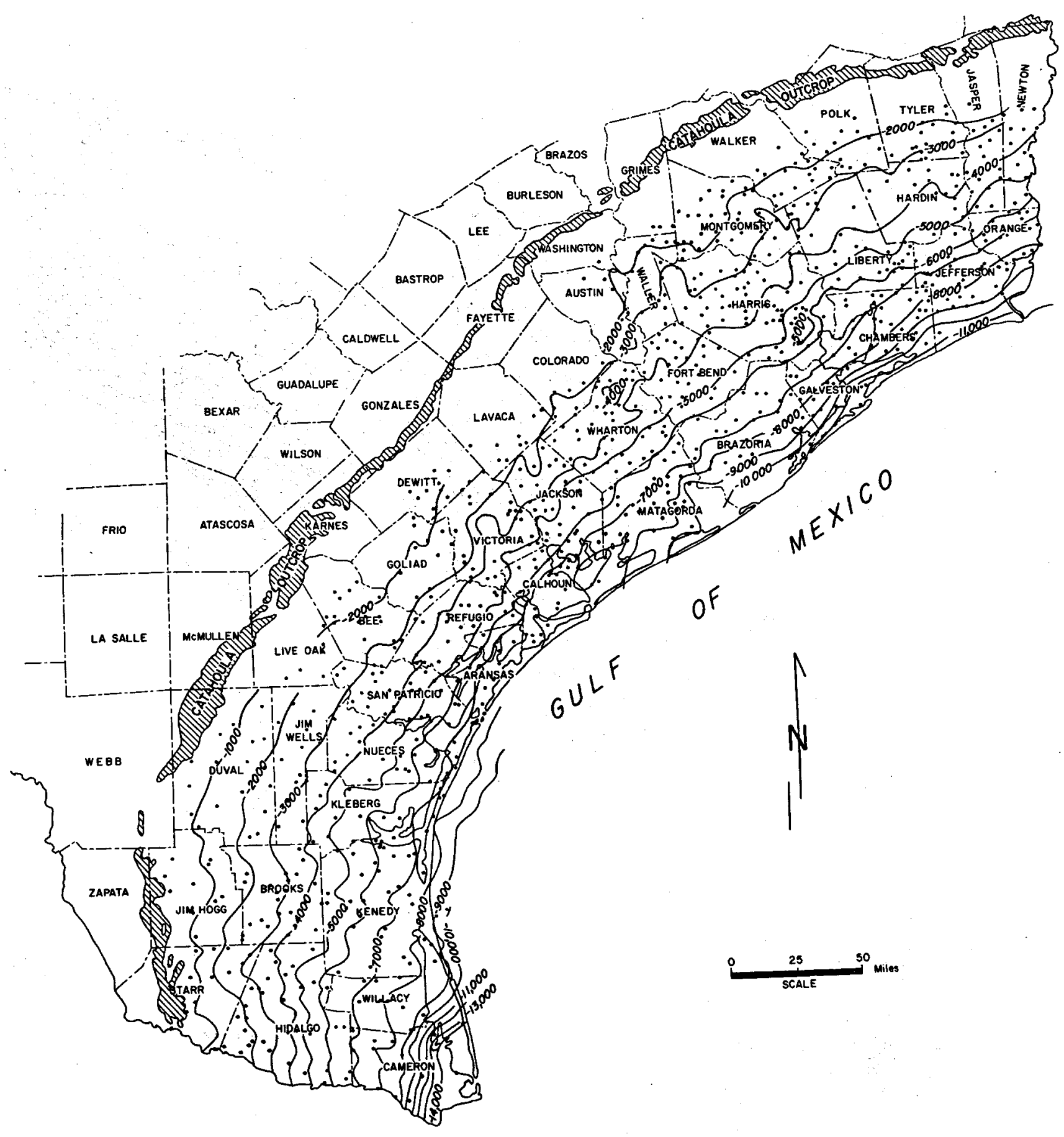

Figure 10. Structure on top of the Frio Formation. 


\section{Regional Geologic Investigation Based on Grid of Frio Correlation Sections}

To facilitate the study of the regional sandstone distribution, the Frio Formation has been subdivided into six units by means of a grid of correlation cross sections and micropaleontological control.

Regional assessment employs a data base of electrical logs from widely spaced wells, approximately 5 to 10 miles apart (fig. 1.1). Correlation of the well logs is accomplished by means of a grid of dip and strike cross sections. Foraminifer markers (fig. 12) have been used extensively in order to establish the correlation fabric on the sections, but they have not been used for detailed correlation from well to well. Correlation lines, " $T$ " markers, were established within the Frio using the micropaleontology and pattern correlation of the electricallogs: This resulted in the subdivision of the formation into six thinner and thus more meaningful mapping units (figs. 13 to 15). Growth faults, which are abundant in the Frio, have been omitted from these regional correlation cross sections in order that the depositional patterns and regional changes in sandstone distribution may be more readily recognized.

Regional cross sections (figs. 13 to 15 ) show that the main sand depocenter, located approximately in the center of the section and outlined by the stippled pattern, occurs fron! 6,000 to 9,000 feet below sea level. The main sand depocenter shifts gulfward in successively younger units with local exceptions as shown in the lower unit on the WW' section (fig. 15). Amount of progradation varies along the trend. Top of the geopressure zone occurs within or just below these massive sandstones. Isothermal lines indicate that fluids in these thick sandstones have temperatures lower than $200^{\circ} \mathrm{F}$. Thick sandstones were deposited as high-constructive lobate deltas along the Lower and Upper Texas Gulf Coast (figs. 13 and 15), and as barrier bars along the Middle Texas Gulf Coast (fig. 14). Updip of the main sand depocenter, the section thins and is composed dominantly of shale with thin, discontinuous sandstone beds, typical of fluvial sequences. Down dip of the main sand depocenter, the section thickens but is composed dominantly of shale with thin, local sandstone beds deposited in prodelta and shelf environments. The $300^{\circ} \mathrm{F}$ isotherm occurs within these prodelta and shelf facies except where movement along enormous growth faults has resulted in the subsidence of thick deltaic sandstones to similar depths (figs. 13 and 15). 


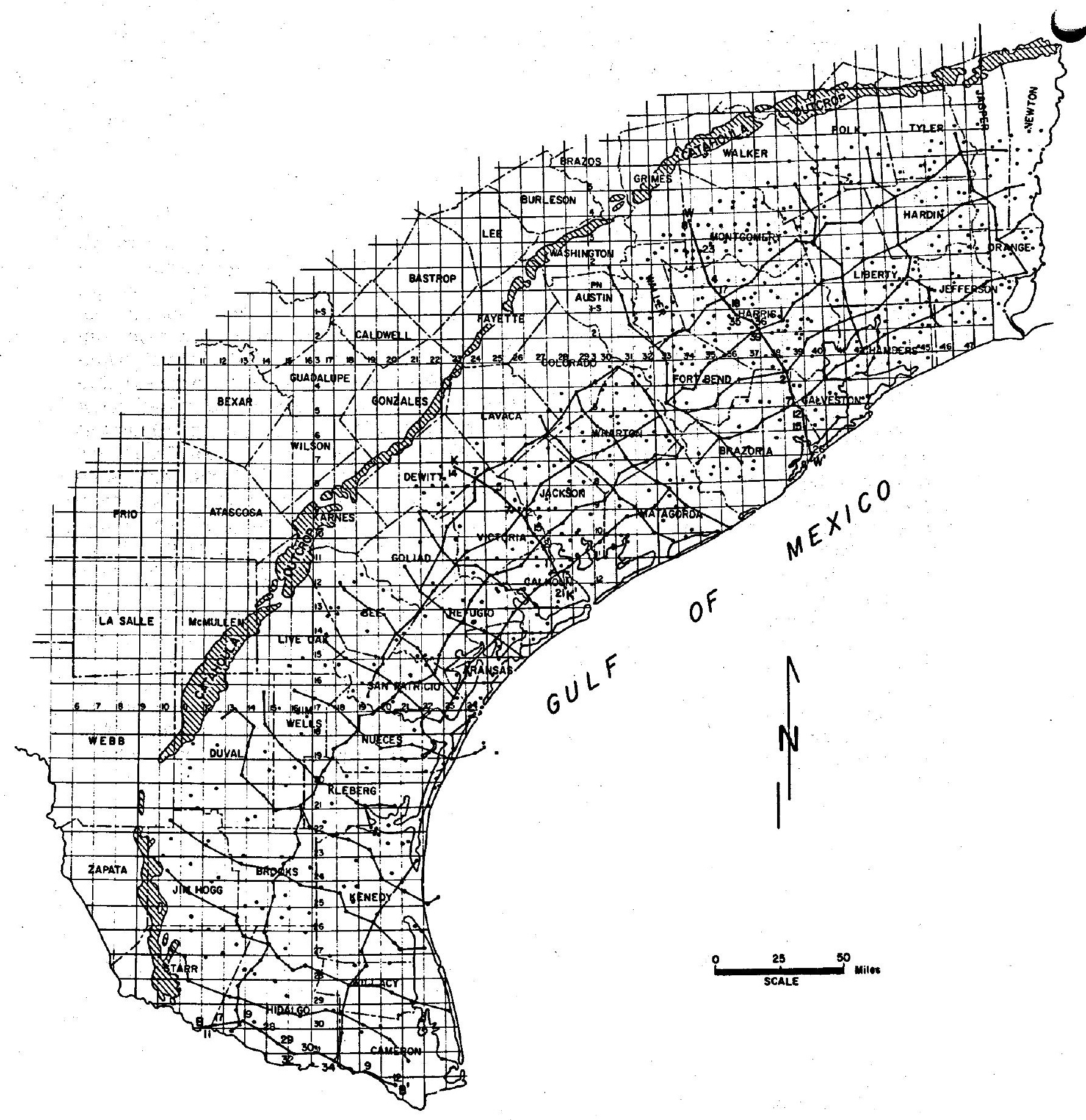

Figure 11. Well-log control and cross sections constructed for regional study of the Frio Formation. Dip sections $B B^{\prime}, K K^{\prime}$, and $W W^{\prime}$ are included in this report. 


\begin{tabular}{|l|l|l|}
\hline SERIES & GROUP/FORMATION & \\
\hline Miocene & Anahuac & $\begin{array}{l}\text { Discorbis nomada } \\
\text { Heterostegina texana }\end{array}$ \\
\hline Oligocene & Frio & $\begin{array}{l}\text { Marginulina vaginata } \\
\text { Cibicides hazzardi } \\
\text { Nonion struma } \\
\text { Nodosaria blanpiedi } \\
\text { Textularia mississippiensis } \\
\text { Anomalia bilateral is }\end{array}$ \\
\hline & Vicksburg & Textularia warreni \\
\hline
\end{tabular}

Figure 12. Foraminifer markers, Miocene and 01igocene of the Texas Gulf Coast.

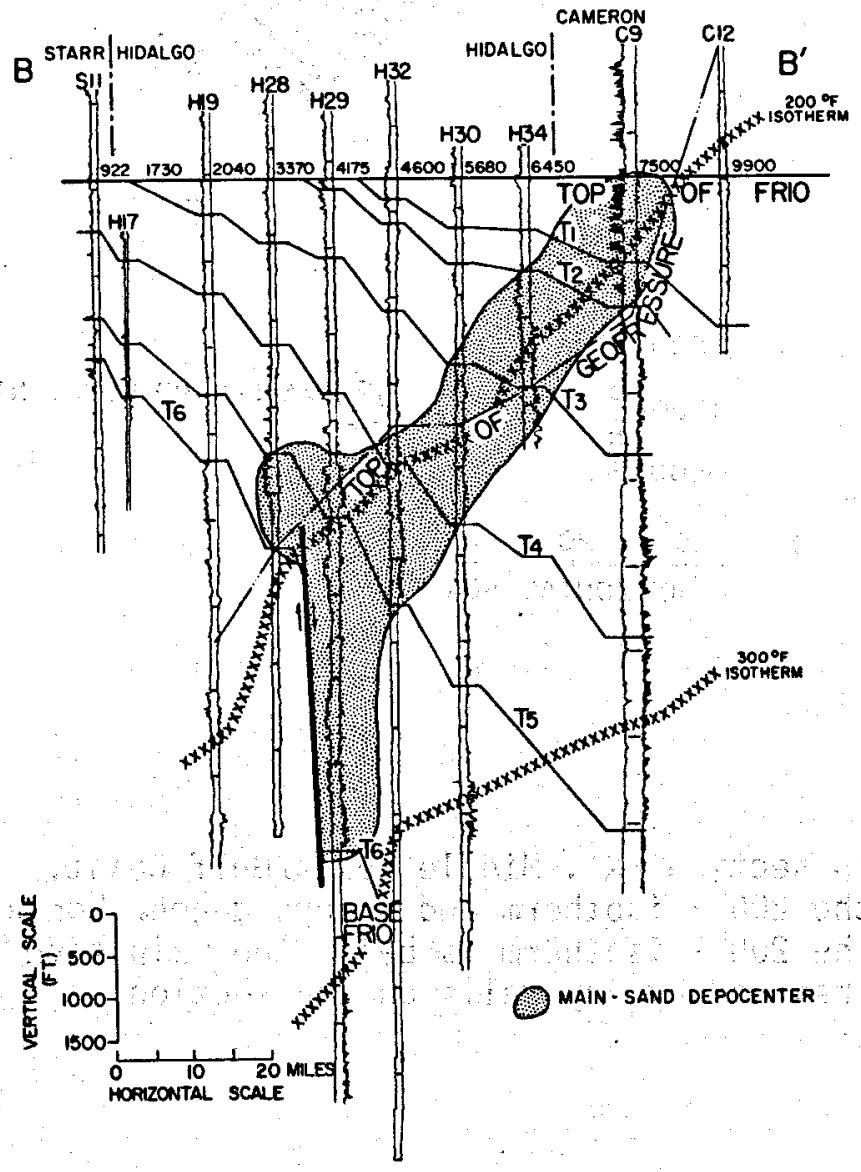

Figure 13. Dip section BB', Lower Texas Gulf Coast. Top of geopressure occurs approximately at the $200^{\mathrm{F}}$ isotherm. The $200^{\circ} \mathrm{F}$ isotherm falls within and the $300 \mathrm{~F}$ isotherm is below the main sand depocenter. Potential geothermal reservoirs must lie beneath the $300 \mathrm{~F}$ isotherm. 


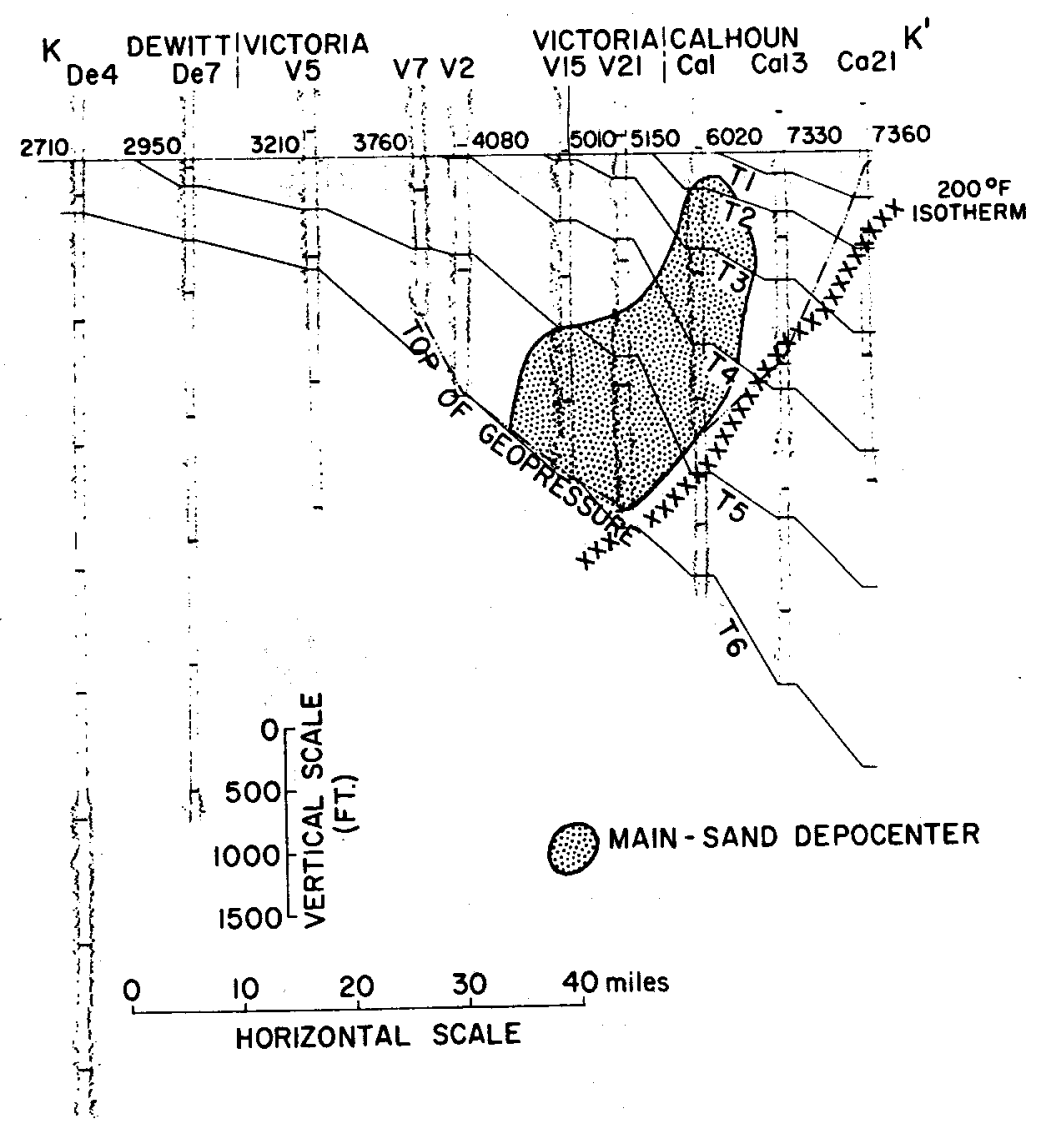

Figure 14. Dip section KK', Middle Texas Gulf Coast. Top of geopressure occurs above the $200 \mathrm{~F}$ isotherm and occurs deeper beneath the main sand depocenter. The $200^{\circ} \mathrm{F}$ isotherm is below the main sand depocenter and $300 \mathrm{~F}$ was not reached by any wells on the section. 


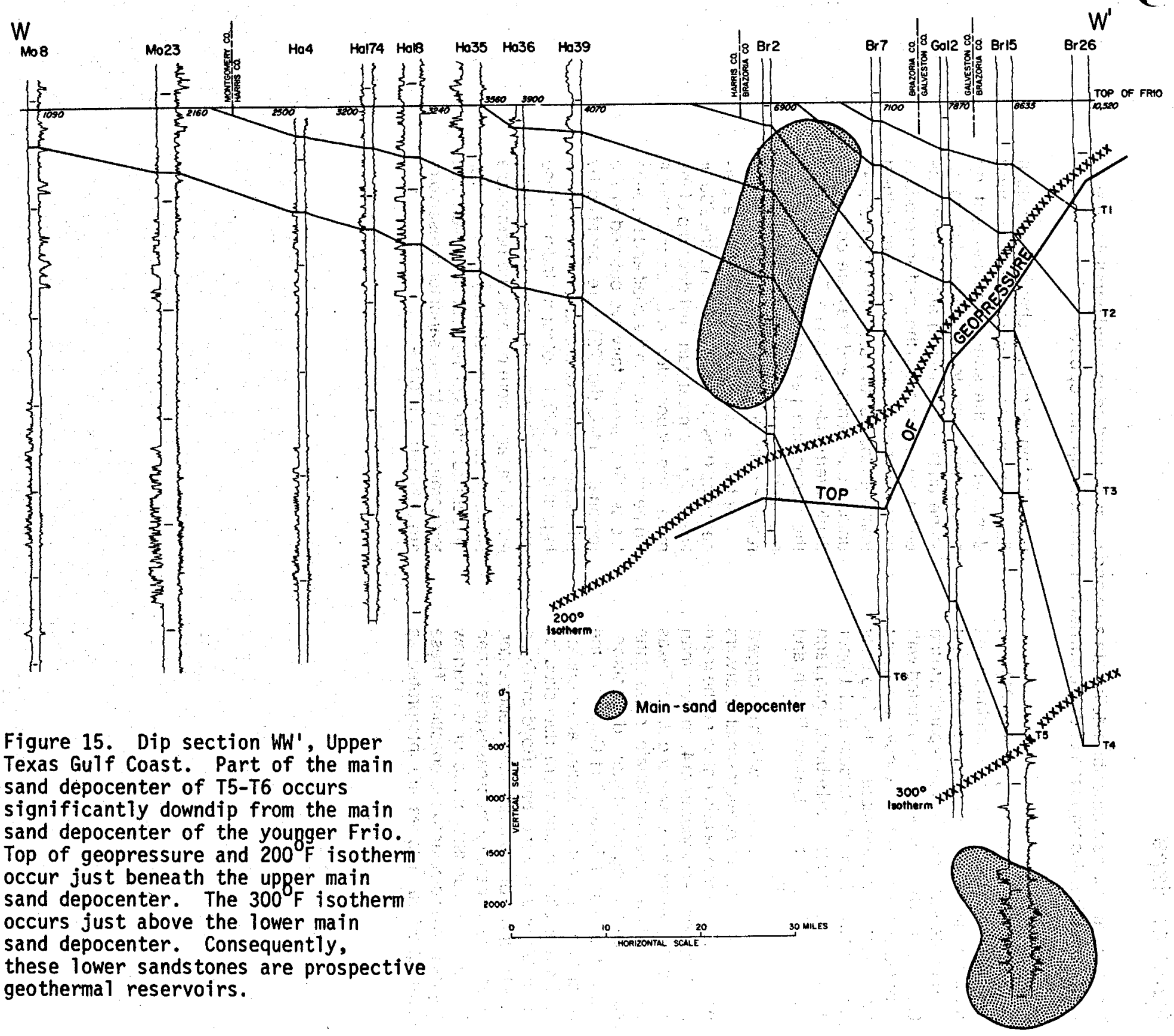




\section{Interpretation of Depositional Environments from Sandstone Percent Maps}

Maps of sandstone distribution delineate an elongate main sandstone trend parallel to the Gulf Coast that is composed of delta, barrier bar, and strandplain deposits.

Sandstone percent (figs. 16 to 21) and net-sandstone maps of each correlation unit on the regional sections define main sand depocenters as elongate trends parallel to the Gulf Coast. These trends are illustrated with stippled patterns on the sandstone percent maps. Net-sandstone maps of the Frio units are available from the Middle and Upper Texas Gulf Coast reports (Bebout, Agagu and Dorfman, 1975; Bebout, Loucks, Bosch, and Dorfman, 1976).

In unit T5-T6, the unit in which the largest number of prospective geothermal reservoirs occur, the sandstone percent along the main sand depocenter ranges from 40 to more than 60 (fig. 16). Along the Lower and Upper Texas Gulf Coast the somewhat lobate shape of the sandstones suggests deltaic deposition; along the Middle Texas Gulf Coast, on the other hand, sandstone bodies are elongate and strike aligned and were deposited as strandplains and barrier bars (Boyd and Dyer, 1964). Updip of the main sand depocenter. sandstone percentage decreases to less than 30 , and the sandstones occur as narrow bands perpendicular to the coastline. These dip-aligned sandstones are interpreted as representing relict river channels across a fluvial plain. Downdip of the main sand depocenter, the sandstone percentage rapidly decreases to zero. Individual sandstone units are of limited areal extent. The units were deposited in the shelf and prodelta environments. In addition, they are farthest from the source and are finer grained than updip equivalents, and they are commonly thinly interbedded with shale. This pattern on the sandstone percent map of T5-T6 is repeated on the maps of the other correlation units (figs. 17 to 21 ).

Isothermal lines on the sandstone percent map (figs. 16 to 18 ) show that the $200^{\circ} \mathrm{F}$ line is, for the most part, just downdip of the main sand depocenter, and that the $300^{\circ} \mathrm{F}$ isotherm occurs within the shelf and prodelta facies. Geothermal fairways outlined in the regional studies (fig. 22) were identified by this superposition of the sandstone percentage and the $300^{\circ} \mathrm{F}$ isotherm. Updip of these geothermal fairways, much thicker, more extensive, and more porous and permeable sandstones occur which may contain significant quantities of methane; however, fluid temperatures in these sandstone reservoirs are only $150^{\circ}$ to $200^{\circ} \mathrm{F}$. 


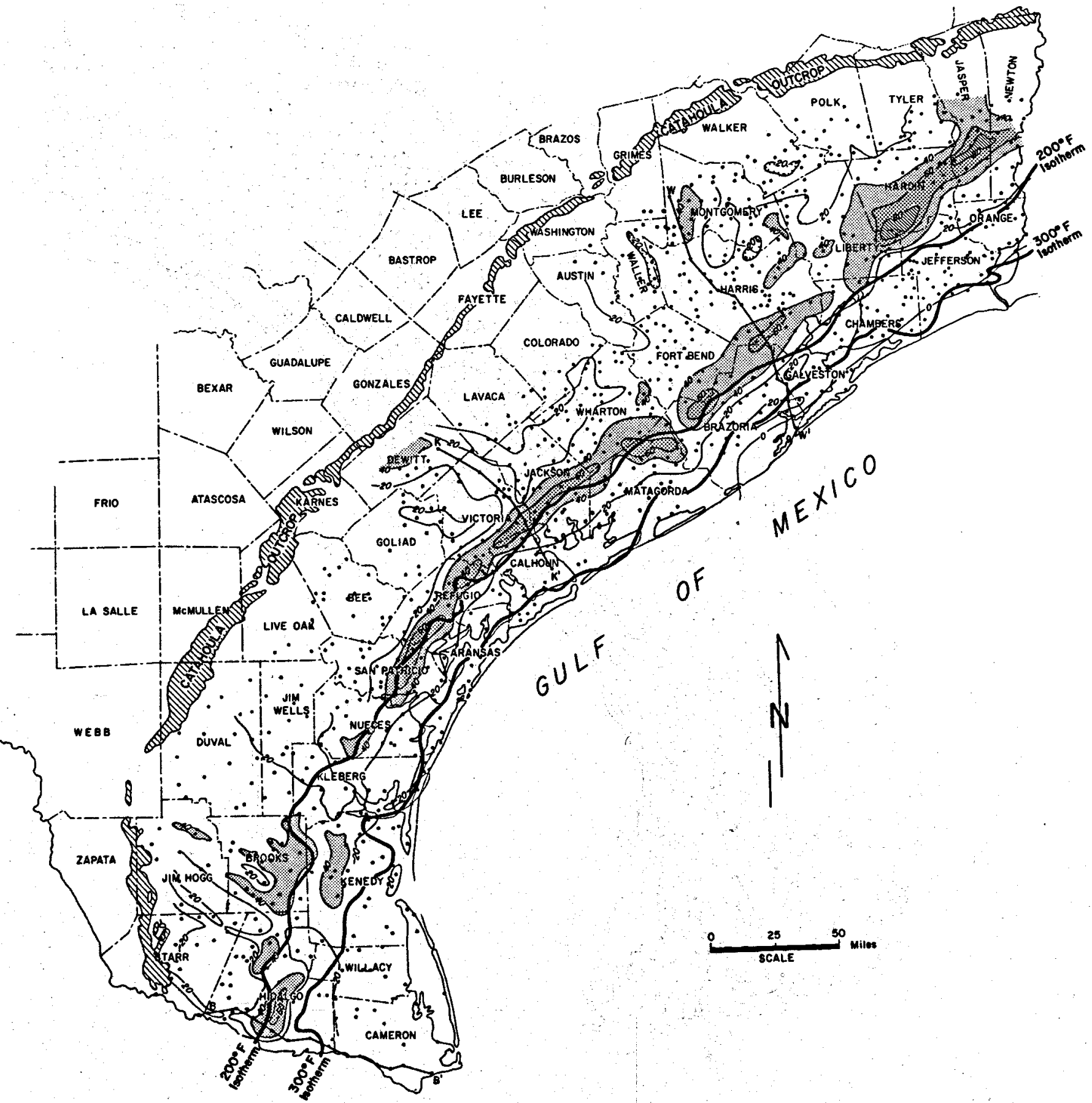

Figure 16. Sand percentage in unit T5-T6. The $200^{\circ} \mathrm{F}$ isotherm occurs within or just downdip of the main sand depocenter. 


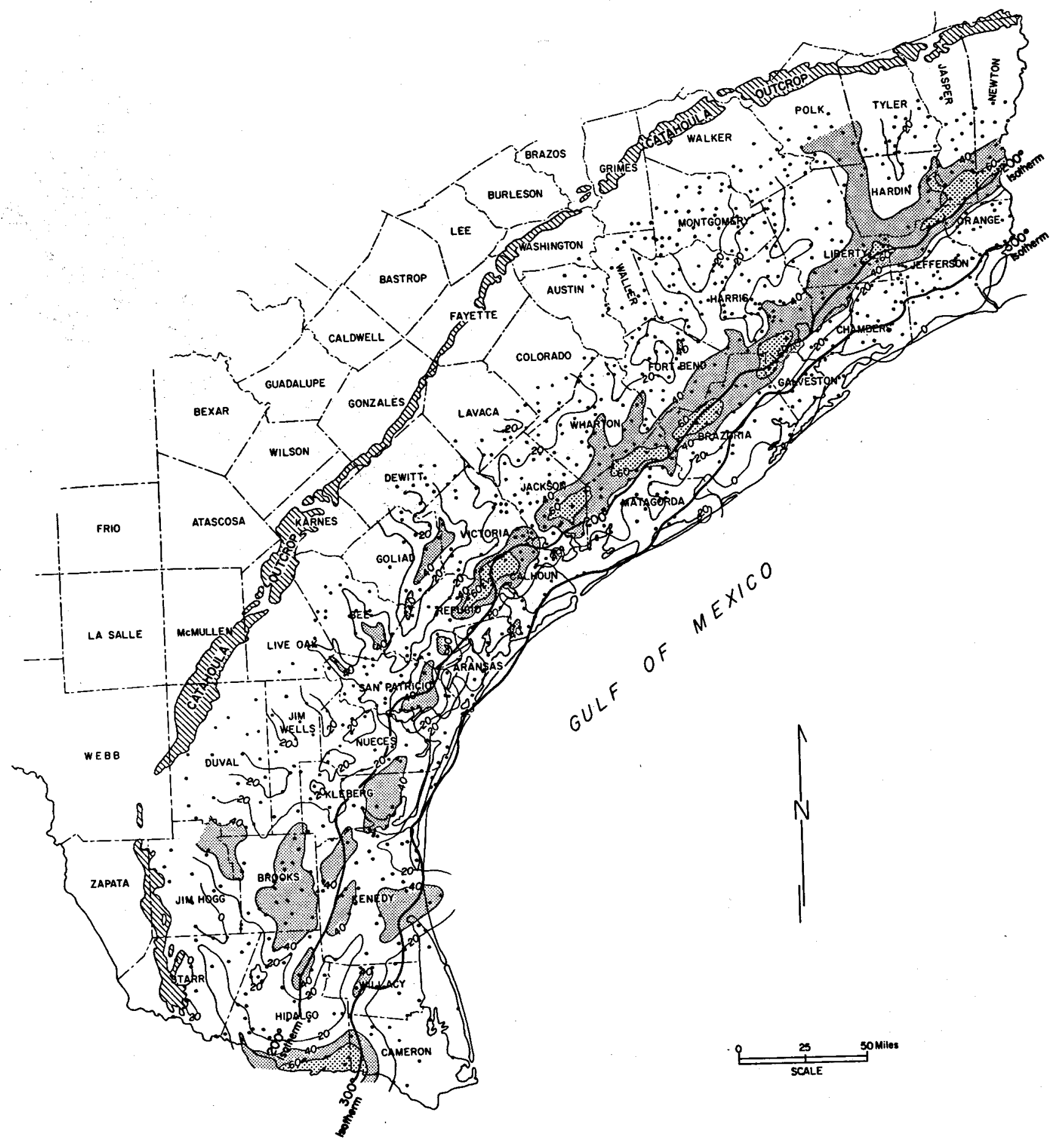

Figure 17. Sand percentage in unit T4-T5. The $200^{\circ} \mathrm{F}$ isotherm occurs within or just downdip of the main sand depocenter. 


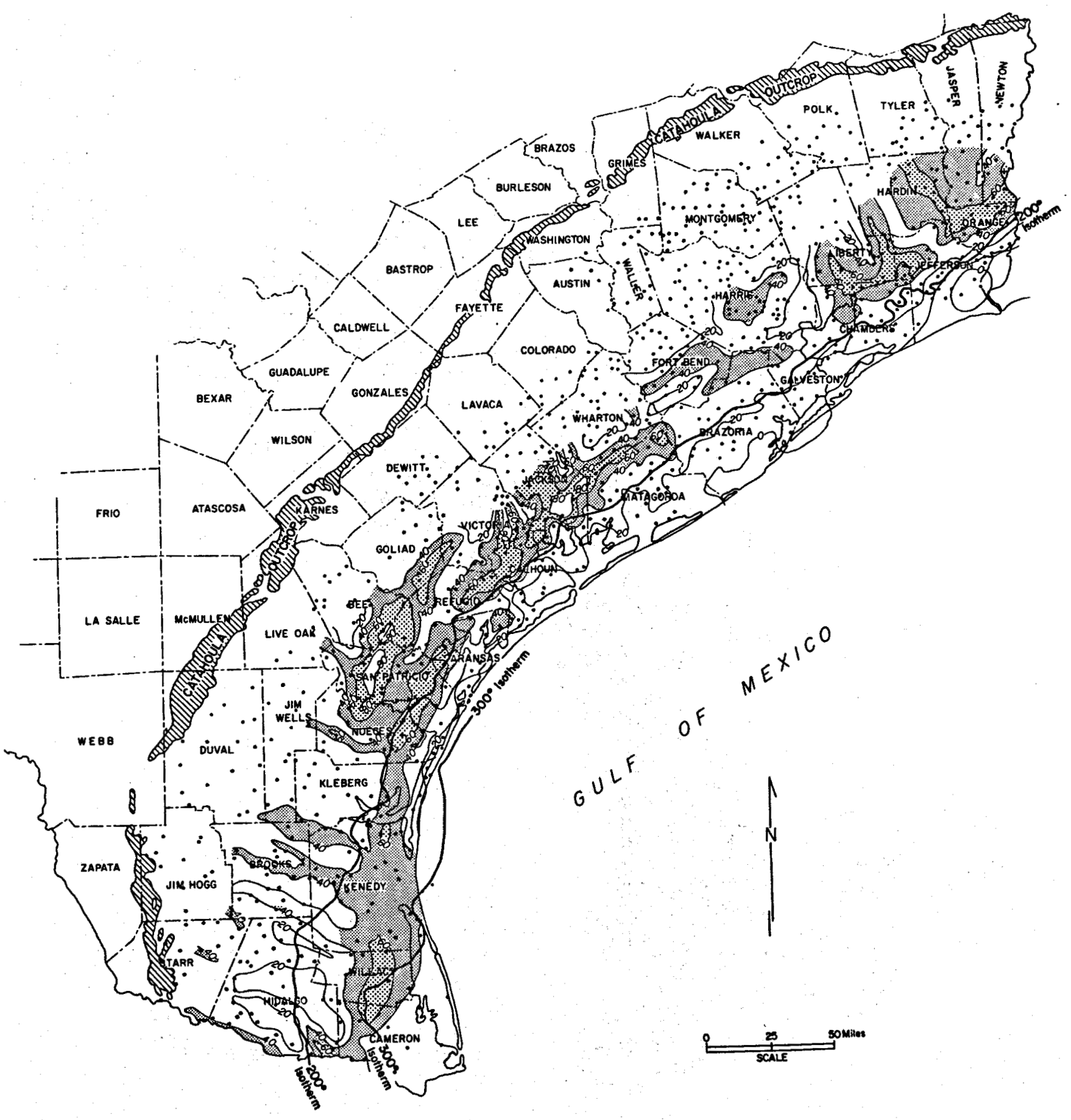

Figure 18. Sand percentage in unit T3-T4. The $200^{\circ} \mathrm{F}$ isotherm occurs within or just downdip of the main sand depocenter. 


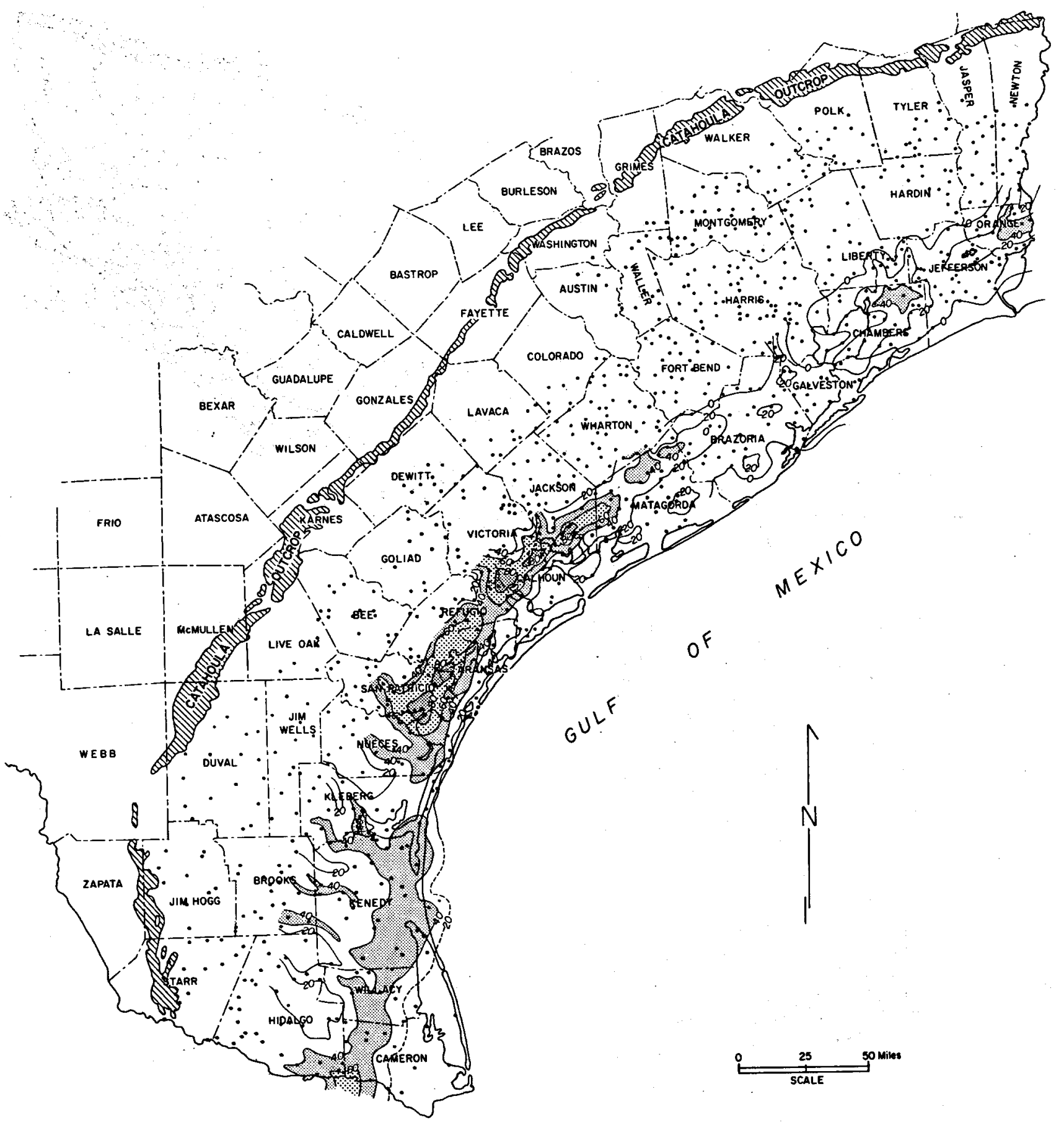

Figure 19. Sand percentage in unit T2-T3. 


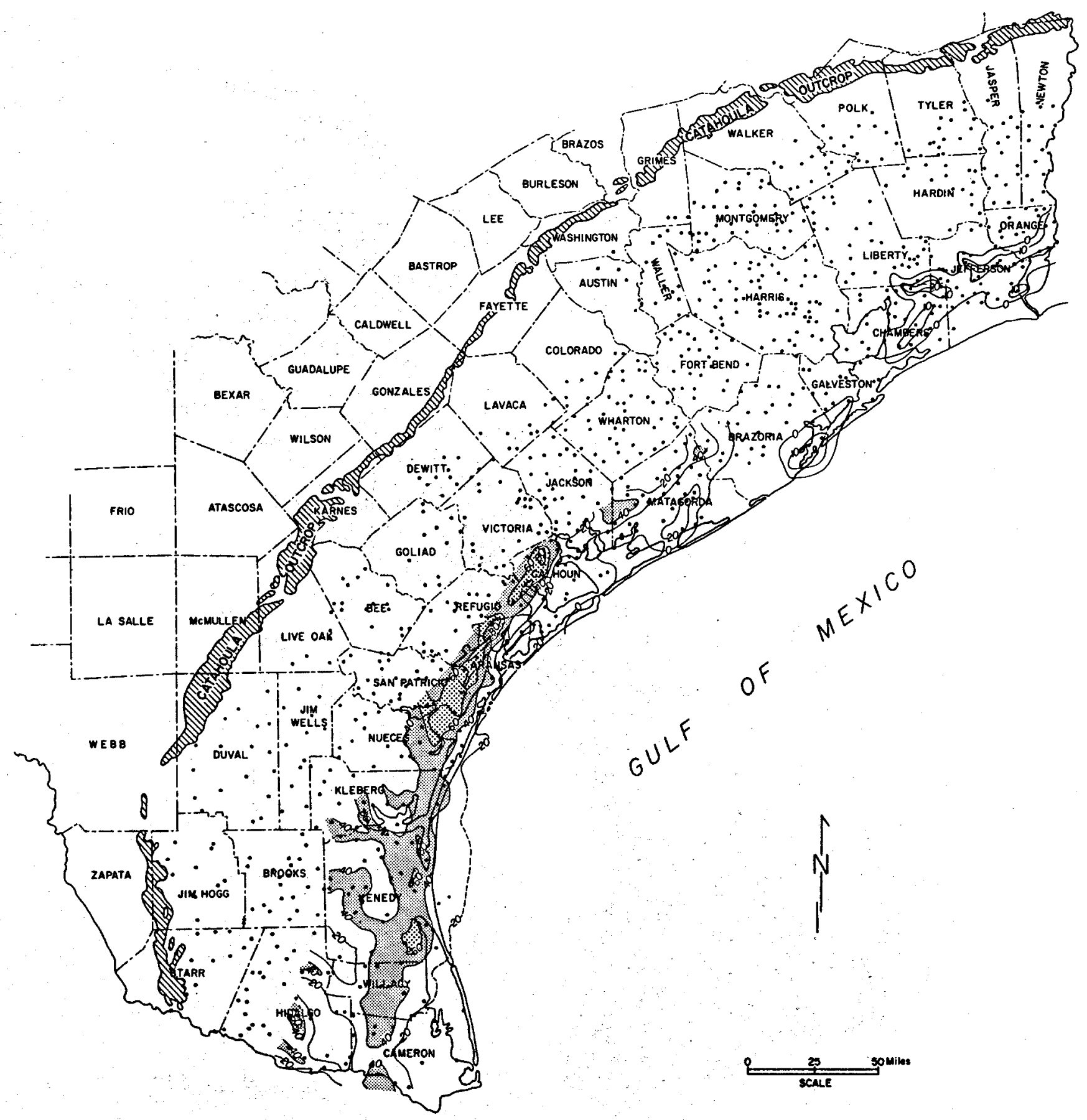

Figure 20. Sand percentage in unit T1-T2, 


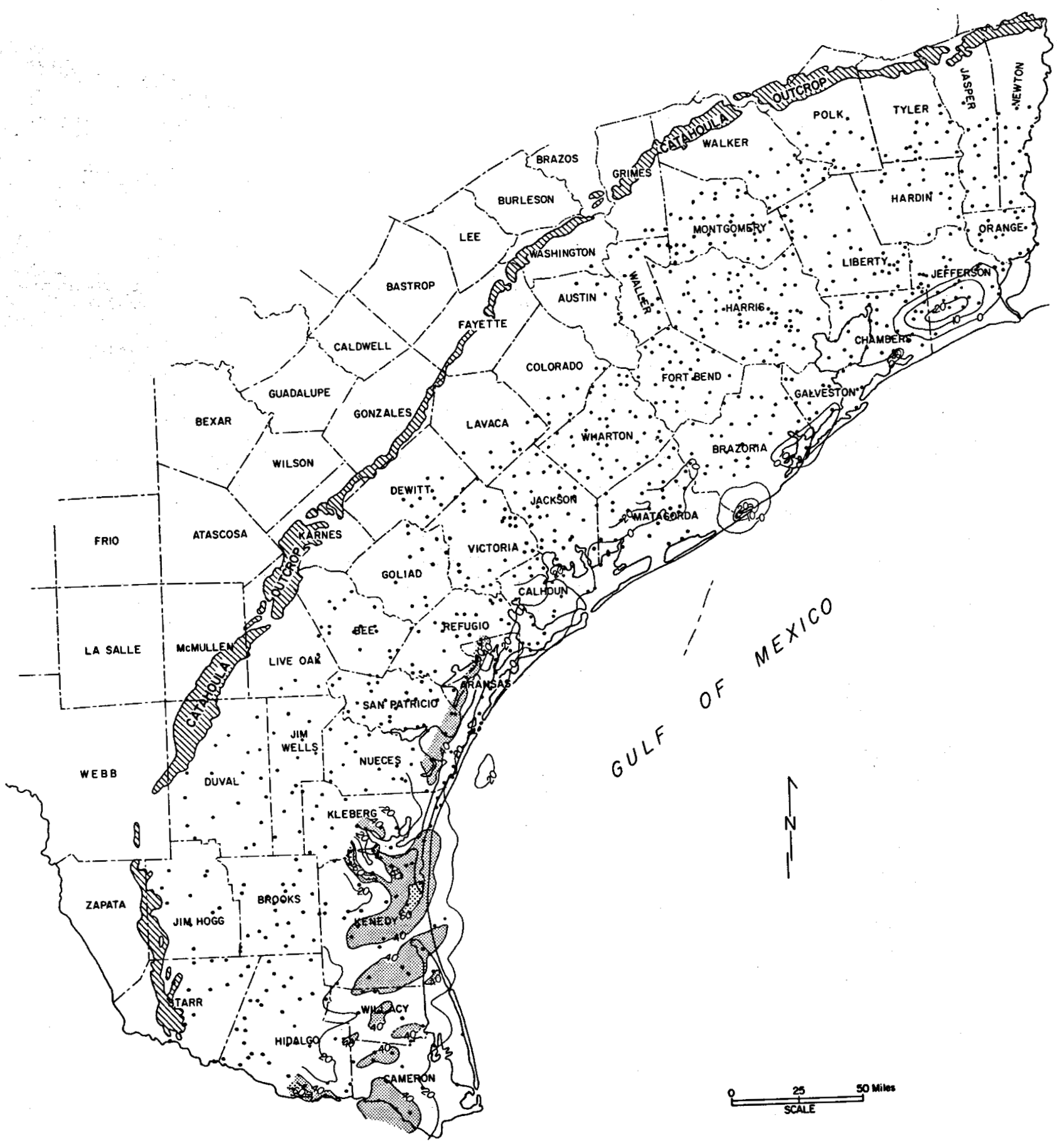

Figure 21. Sand percentage in unit TO-TI. 


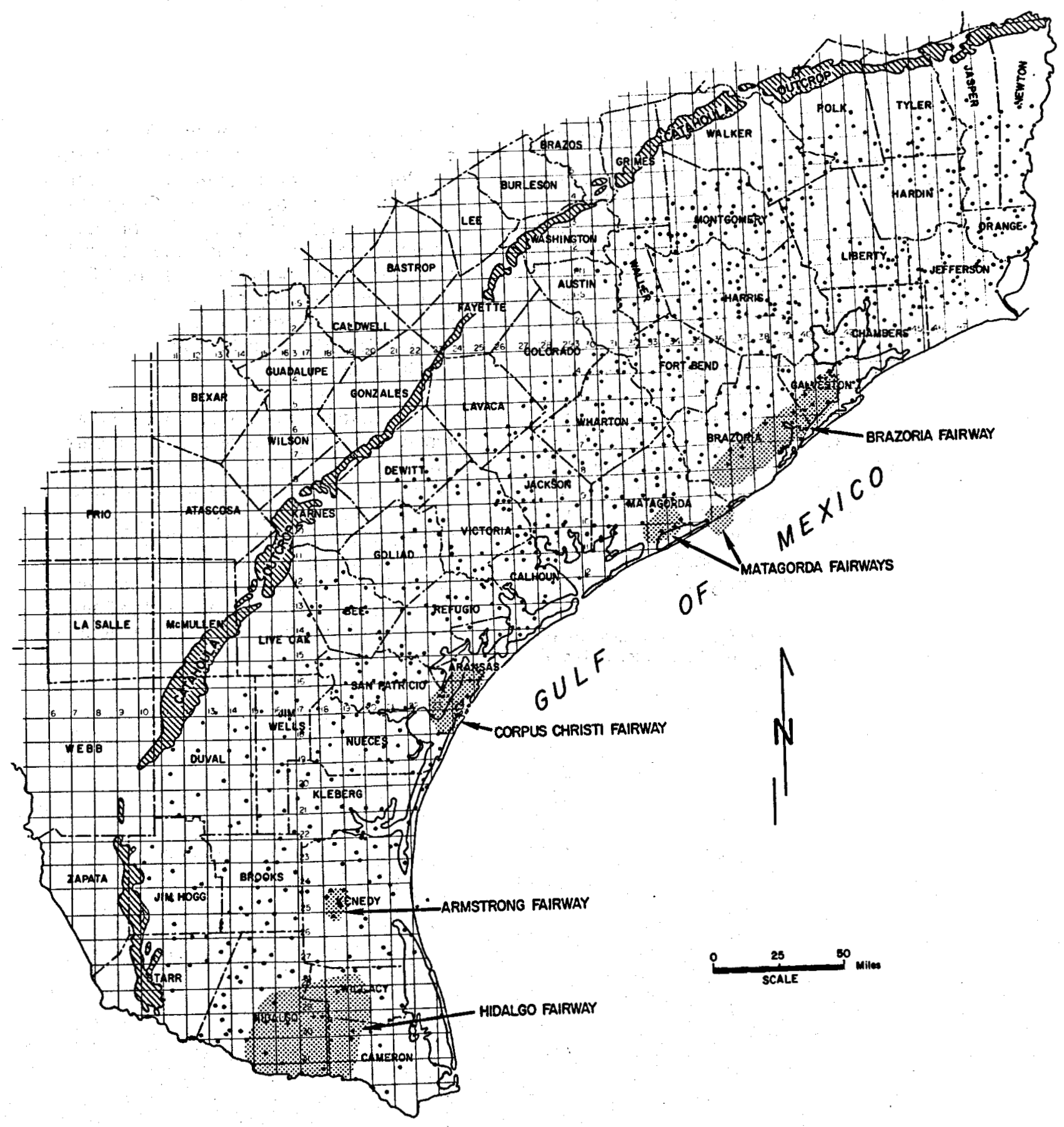

Figure 22. Potential geothermal fairways, Frio Formation, Texas Gulf Coast. 


\section{Hidalgo Fairway}

The Hidalgo Fairway is located in Hidalgo, Cameron, and Willacy Counties and contains many thick, laterally extensive deltaic sandstone bodies with fluid temperatures greater than $300^{\circ} \mathrm{F}$, but with extremely low permeabilities.

The Hidalgo Fairway (fig. 23) was identified by the presence of a very thick sandstone section which occurs between depths of 10,000 and 14,000 feet within the geopressured zone in Hidalgo, Cameron, and Willacy Counties (fig. 24). The Vicksburg and lower Frio section occurs as a series of numerous offlapping deltaic wedges (Bosch, 1975), each of which is considerably smaller in size than the entire fairway. Many of these sandstones have fluid temperatures higher than $300^{\circ} \mathrm{F}$.

Core ${ }^{2}$ analyses of porosity and permeability have been obtained for many wells from this fairway. Below 10,000 feet, porosity is commonly less than 20 percent, and permeability averages less than 1.5 millidarcys (fig. 25). This trend was substantiated by Swanson, Oetking, Osaba, and Hagens (1976) in a study which focused on

2 In this report "core" is synonymous with diamond core, full-diameter core, whole core, and conventional core. the Lower Texas Gulf Coast area from Brooks and Kenedy Counties south to the Mexican border. They concluded that finding adequate permeability was the greatest problem. In their study of fields producing from the geopressured zone, they found that most sandstone permeabilities are 1.0 millidarcy or less. No sandstones with permeabilities of greater than 10 millidarcys were observed deep enough to have temperatures of $300^{\circ} \mathrm{F}$ (fig. 26).

In summary, numerous thick sandstone reservoirs of adequate size occur at depths greater than 13,000 feet in the Hidalgo Fairway, some with fluid temperatures of $300^{\circ} \mathrm{F}$ or higher. An overwhelming number of core analyses with extremely low permeabilities suggests, however; that finding adequate permeability is a major problem in the area. Consequently, the Hidalgo Fairway is not recommended as a potential geothermal prospect. 


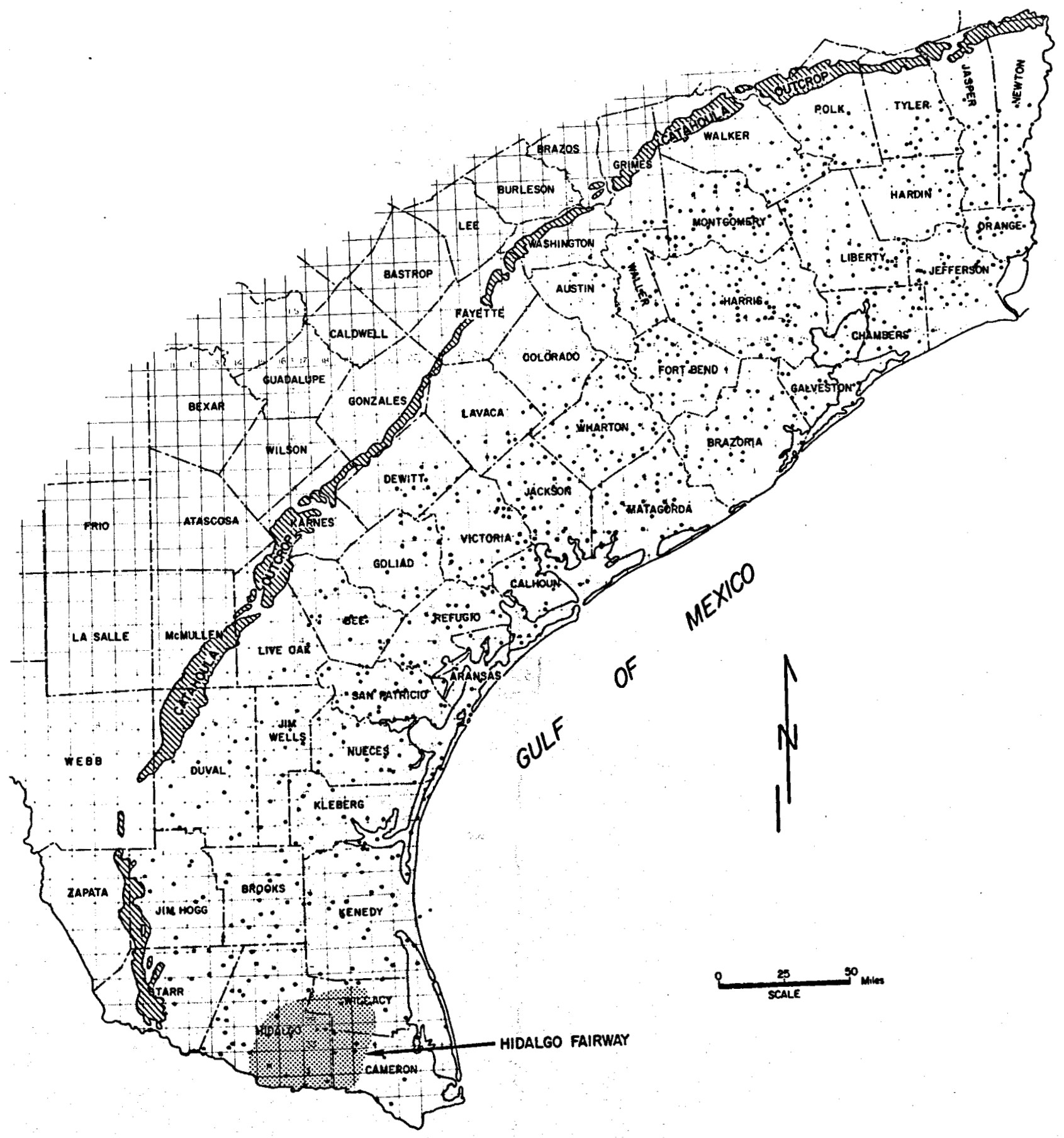

Figure 23. Hidalgo Fiarway. 


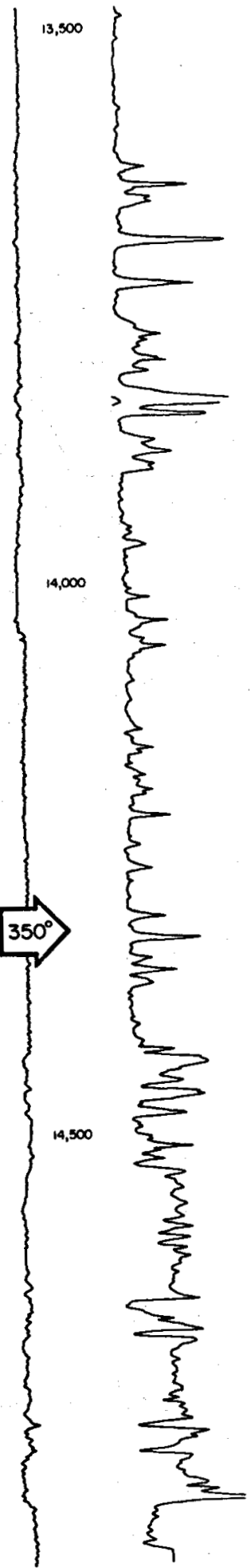

Figure 24. Typical electrical log from the Hidalgo Fairway showing presence of thick sandstone beds below 14,000 feet. 
DEPTH

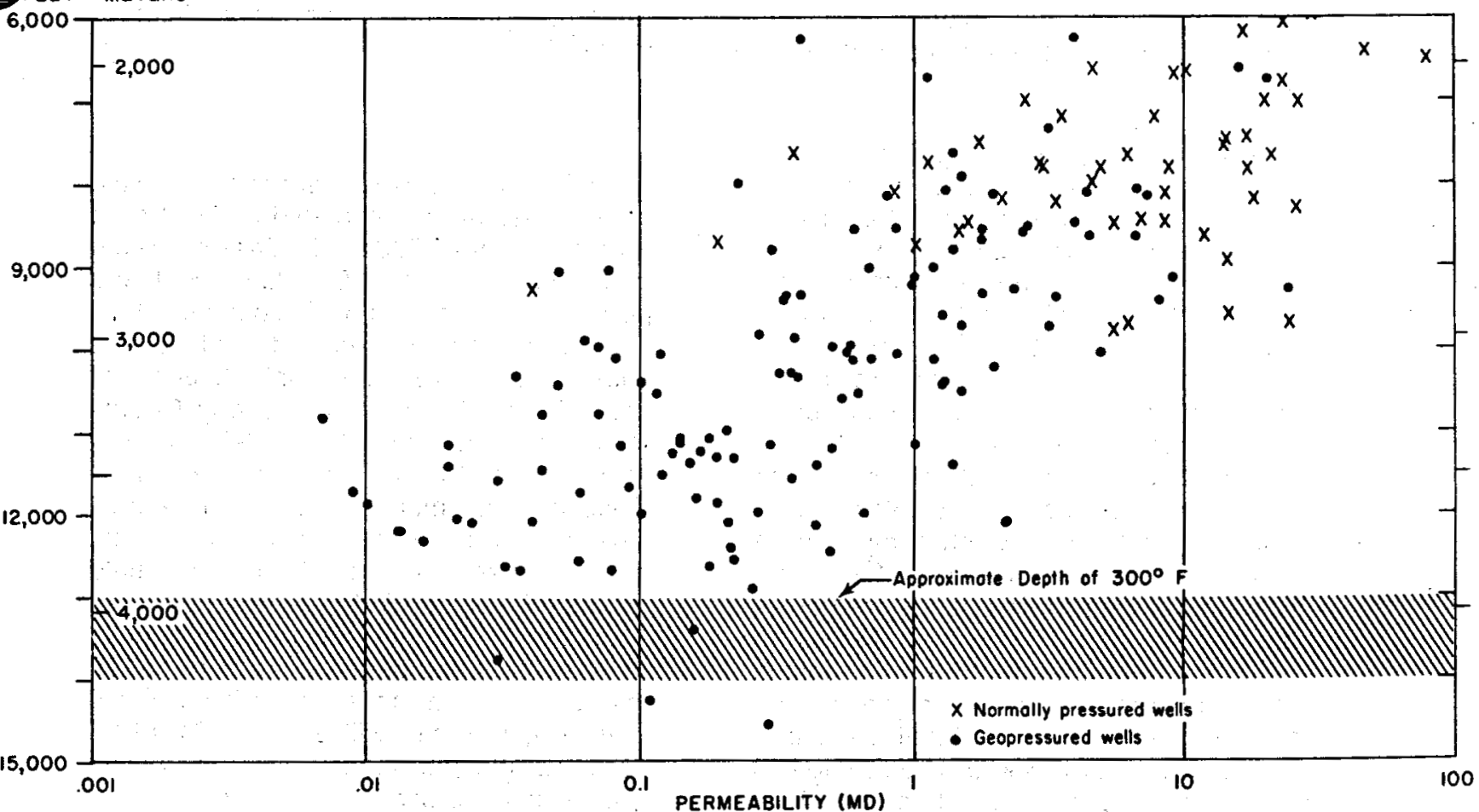

Figure 25. Effective permeability versus depth in gas wells in Hidalgo, Brooks, Cameron, and Kenedy Counties, Lower Texas Gulf Coast (after Swanson, Oetking, Osaba, and Hagins, 1976). At temperatures of $300^{\circ} \mathrm{F}$ and greater permeability is less than 1 millidarcy.

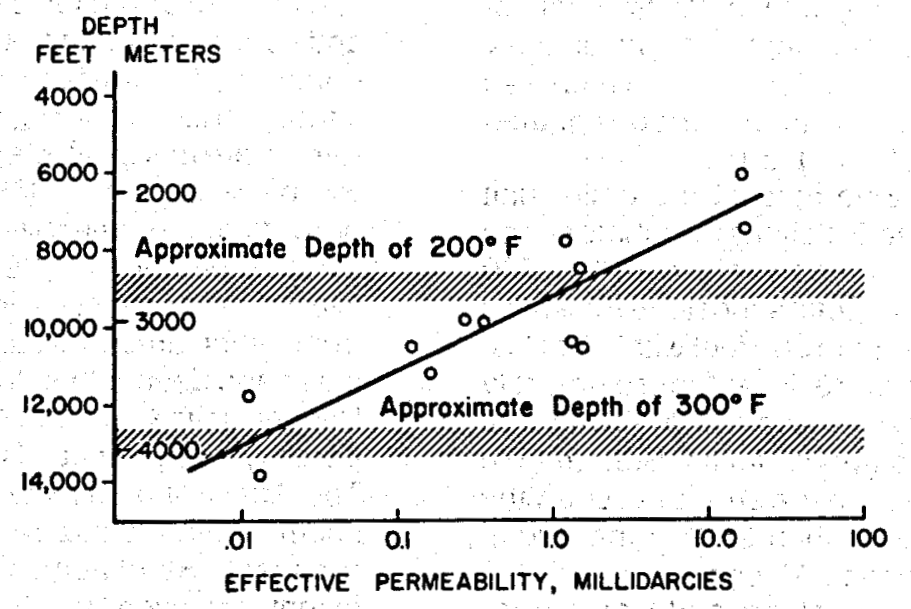

Figure 26. Effective permeability versus depth in gas wells from McAllenPharr area (after Swanson, Oetking, Osaba, and Hagins, 1976). 
The Armstrong Fairway, located in Kenedy County, contains a number of thick sandstone units which extend over an area of 50 square miles and have probable core permeabilities of 20 millidarcys, but fluid temperatures of less than $300^{\circ} \mathrm{F}$.

The Armstrong Fairway (fig. 27) is located in west-central Kenedy County and is coincident with the Candelaria field. Sandstone beds of interest here are upper Vicksburg and basal Frio in age and were identified from the regional study of the Frio of the Lower Texas Gulf Coast (Bebout, Dorfman, and Agagu, 1975). The net-sandstone map of the fairway (fig. 28) outlines a lobate area composed of up to 40 percent sandstone.

A cross section through the immediate field area (fig. 29) defines a series of sandstone and shale beds which comprises an interval approximately 1,100 feet thick updip of the field area; sandstone bodies here range from 10 to 50 feet thick. Across the major growth fault and into the Candelaria field (Armstrong wells), the same section thickens to more than 1,500 feet, and sandstone beds range in thickness from 10 to 200 feet. The thickest sandstone body occurs in the center of the field in the Humble No. 21 Armstrong well. Gulfward, and particularly across the next growth fault, the saridstone thins significantly. Thinning is best documented by the Humble No. 1 S. K. East " $G$ " at the downdip end of the cross section where sandstone beds are only 10 to 50 feet thick. The potential geothermal reservoir lies between these two growth faults, each of which has a displacement of approximately 1,000 feet. The high-sand section has been further subdivided into three parts designated "A", "B", and "C" (fig. 29).

A net-sandstone map of the entire unit (fig. 28) more clearly defines the lobate shape and outlines two areas where more than 700 feet of sand occur. Total sandstone thickness decreases to less than 300 feet within 3 miles. Top of geopressure is at approximately 11,000 feet below sea level in the fairway area between the two growth faults. Bottom-hole temperature readings are erratic but show the " $\mathrm{C}$ " unit to be less than $250^{\circ} \mathrm{F}$; the $300^{\circ} \mathrm{F}$ lines lie beneath the " $A$ " unit.

Core analyses of porosity and permeability are unavailable in the Armstrong Fairway from the depths of interest between
11,000 and 13,000 feet subsea. Sidewallcore analyses from Humble No. 20 Armstrong from depths of 17,280 to 17,774 feet indicate porosity ranging from 15 to 25 percent, and permeability from 0 to 30 millidarcys. However, permeability from sidewall core is known to be high and unreliable. Analyses of cores from other wells in Kenedy County show that, deeper than 13,000 feet, porosity ranges from 11 to 18 percent, and permeability is commonly less than 1 millidarcy. One mile north of the Armstrong Fairway, core analyses from the Sarita East field (HumbleS.K. East " $B$ ". No. 18) from depths of 11,622 to 11,663 feet indicate porosity of 21 to 30 percent and permeability of 10 to 126 millidarcys. From these data it is estimated that core porosity will average 21 to 25 percent, and permeability will be 20 millidarcys in the prospective reservoir.

In summary, reservoir size is adequate in the Armstrong Fairway. Total net sandstone of more than 300 feet occurs over an area of 50 square miles. Thinner sandstones to the north and south of the outlined area will also be in continuity with the thicker sands but the reservoir is probably limited to the east and west by major growth faults. Maximum thickness of unbroken sandstone is $200 \mathrm{feet}$, and sandstones 30 to 50 feet thick are more common. Subsurface fluid temperatures, although quite variable, indicate that temperatures are marginal. Maximum temperatures will be less than $300^{\circ} \mathrm{F}$. Interpolated core porosity and permeability of the " $\mathrm{C}$ " unit are 21 to 25 percent and 20 millidarcys, respectively. These estimates are based on analyses from other areas of sandstones both shallower and deeper than the section of interest. Deeper units (" $B$ " and " $A$ ") will have lower porosity and permeability than the " $C$ " unit. The Armstrong Fairway does not meet minimum requirements as a potential geothermal prospect. Sandstone thickness and areal extent are excellent; low fluid temperature and probable low permeability are the major problems. 


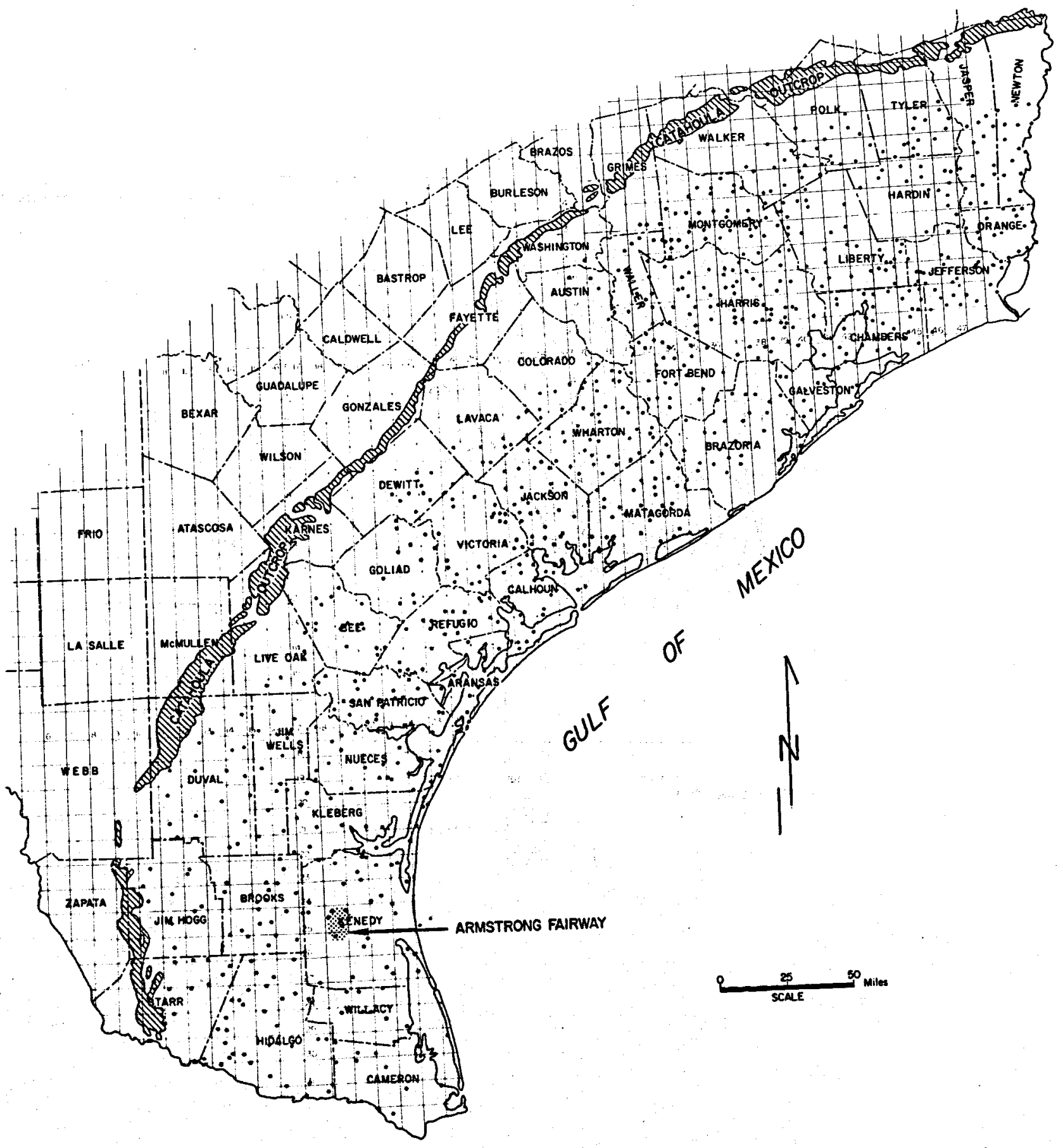

Figure 27. Armstrong Fairway. 


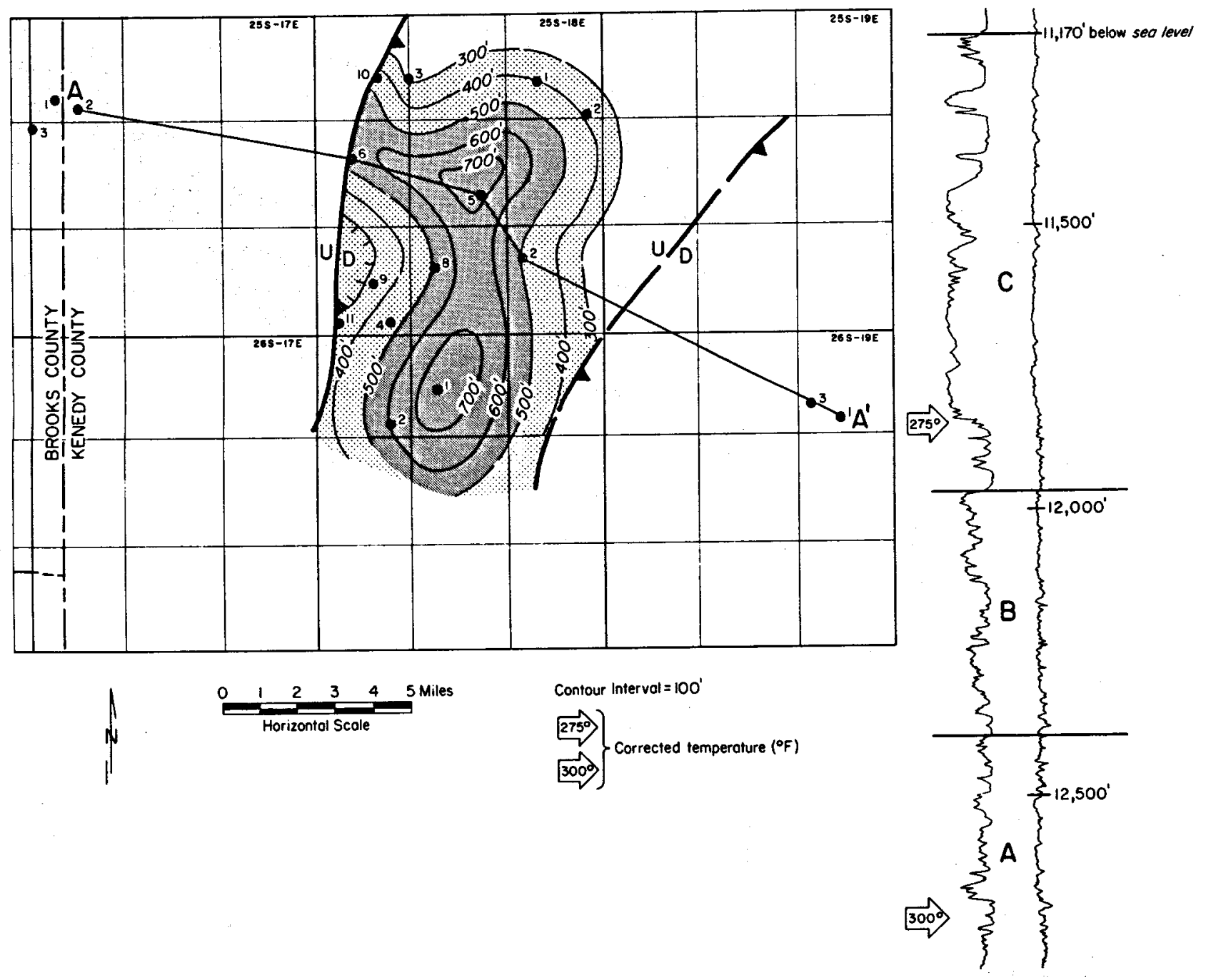

Figure 28. Frio net sandstone, Armstrong Fairway. Also shown are growth faults, isothermal lines, and line of dip section $A A^{\prime}$. Electrical log from the Humble No. 22 Armstrong well shows typical sandstone bodies and correlation units on figure 29. 
A

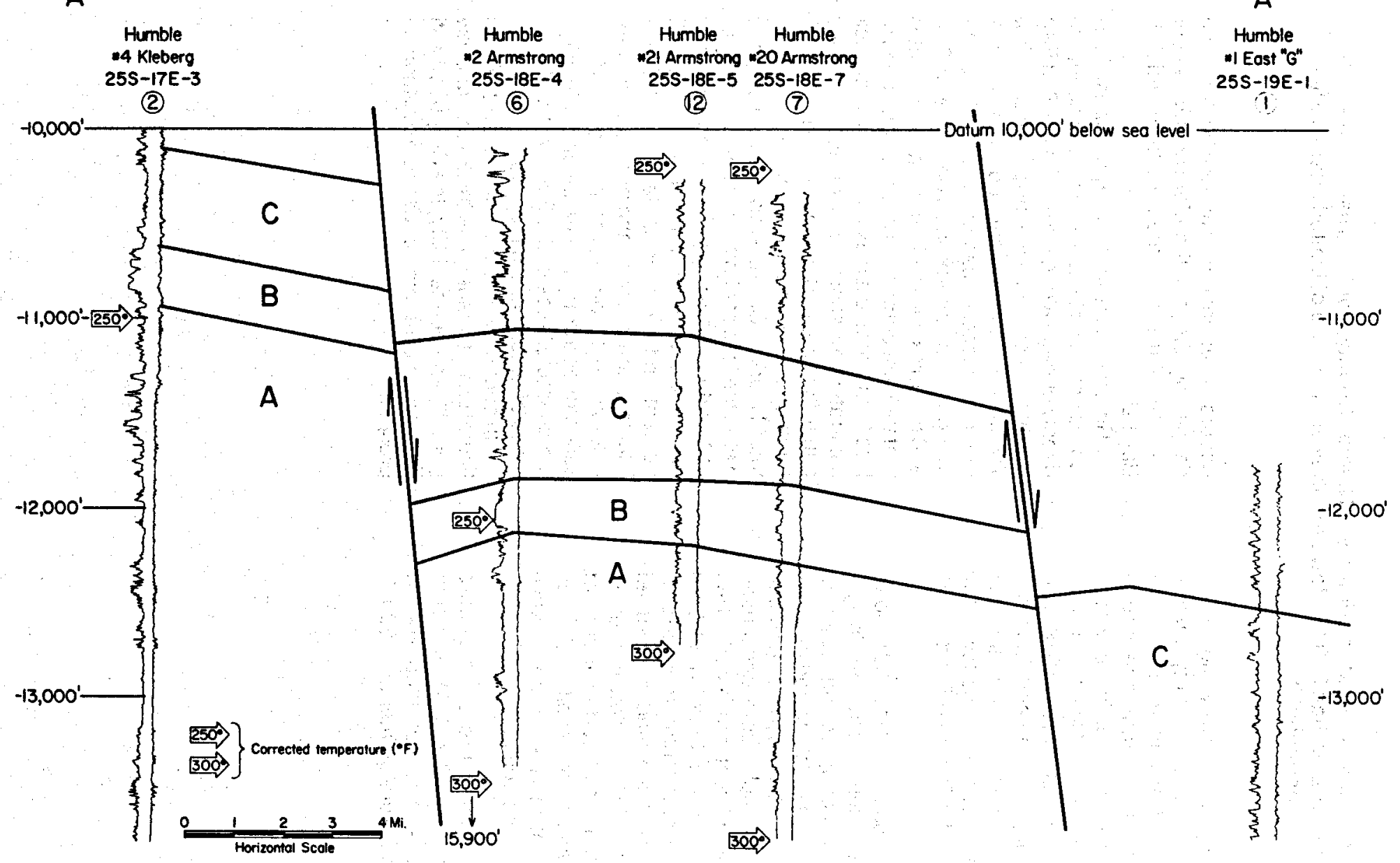

Figure 29. Dip section $A A^{\prime}$ across the Armstrong Fairway. Although temperatures are erratic from well to well, they indicate that all of the sandstone reservoirs have fluid temperatures lower than $300 \% \mathrm{~F}$. 


\section{The Corpus Christi Fairway}

The Corpus Christi Fairway, located primarily in Nueces County, contains sandstone units with temperatures greater than $300^{\circ} \mathrm{F}$. However, they are thin and of limited lateral extent, and they exhibit low permeability.

The Corpus Christi Fairway (fig. 30) is located primarily in Nueces County but also extends into San Patricio and Aransas Counties. Prospective sandstone bodies were identified on a regional cross section from the Middle Texas Gulf Coast Frio study (Bebout, Agagu, and Dorfman, 1976); the best known development of sandstone is in Shell's Red Fish Bay field in Corpus Christi Bay (fig. 31), and it occurs in the lower two correlation units of the Frio (T4-T5 and T5-T6) (fig. 32).

A structural cross section (fig. 32) shows the main sand depocenter (strandplain system) at the upper left or updip end. Downdip to the lower right, the sandstone bodies break up into thin sandstone beds separated by thin shale beds. For example, core description from 14,500 to 14,568 feet from a well in Red Fish Bay field (Shell \# 1 State Tract 346) shows that the sand section is composed of 5to 7-foot-thick beds of fine sand interbedded with shale (fig. 33). These downdip units, composed of thin interbedded layers of sandstone and shale, are shelf and slope deposits equivalent in time to the massive strandplain sandstone updip.

Top of the geopressure zone occurs between 8,500 and 9,000 feet. At this depth the fluid temperature is less than $200^{\circ} \mathrm{F}$. Subsurface temperature greater than $300^{\circ} \mathrm{F}$ occurs at approximately 12,500 feet and deeper (fig. 32), and therefore occurs deeper than the T4 marker in the wells from Red Fish Bay field.

Reservoir size in the Corpus Christi Fairway is unknown because few wells penetrate deeply enough along strike with the Red Fish Bay field. Those wells that do penetrate below T5 are commonly separated from one another by closely spaced growth faults. Although sandstone-prone zones are 400 to 900 feet thick, detailed examination indicates that they are composed of sandstone beds of less than 1 foot to a maximum of 10 feet thick separated by shale beds of approximately equal thickness. Subsurface fluid temperatures of $300^{\circ} \mathrm{F}$ and higher occur just below the T4 marker. Core is available from only one well in the area at depths of interest-the Shell \# 1 State Tract 346 (fig. 33). Analyses of this core show porosity ranging from 9 to 22 percent and permeability less than 5.3 millidarcys. Low porosity and permeability were determined to be representative of all the sandstones through comparison of electrical $\log$ characteristics of the Shell \#1 well with those of other wells in the field.

In summary, because of probable limited lateral extent, inadequate thickness, and low porosity and permeability, the Corpus Christi Fairway is not recommended as a geothermal prospect. 


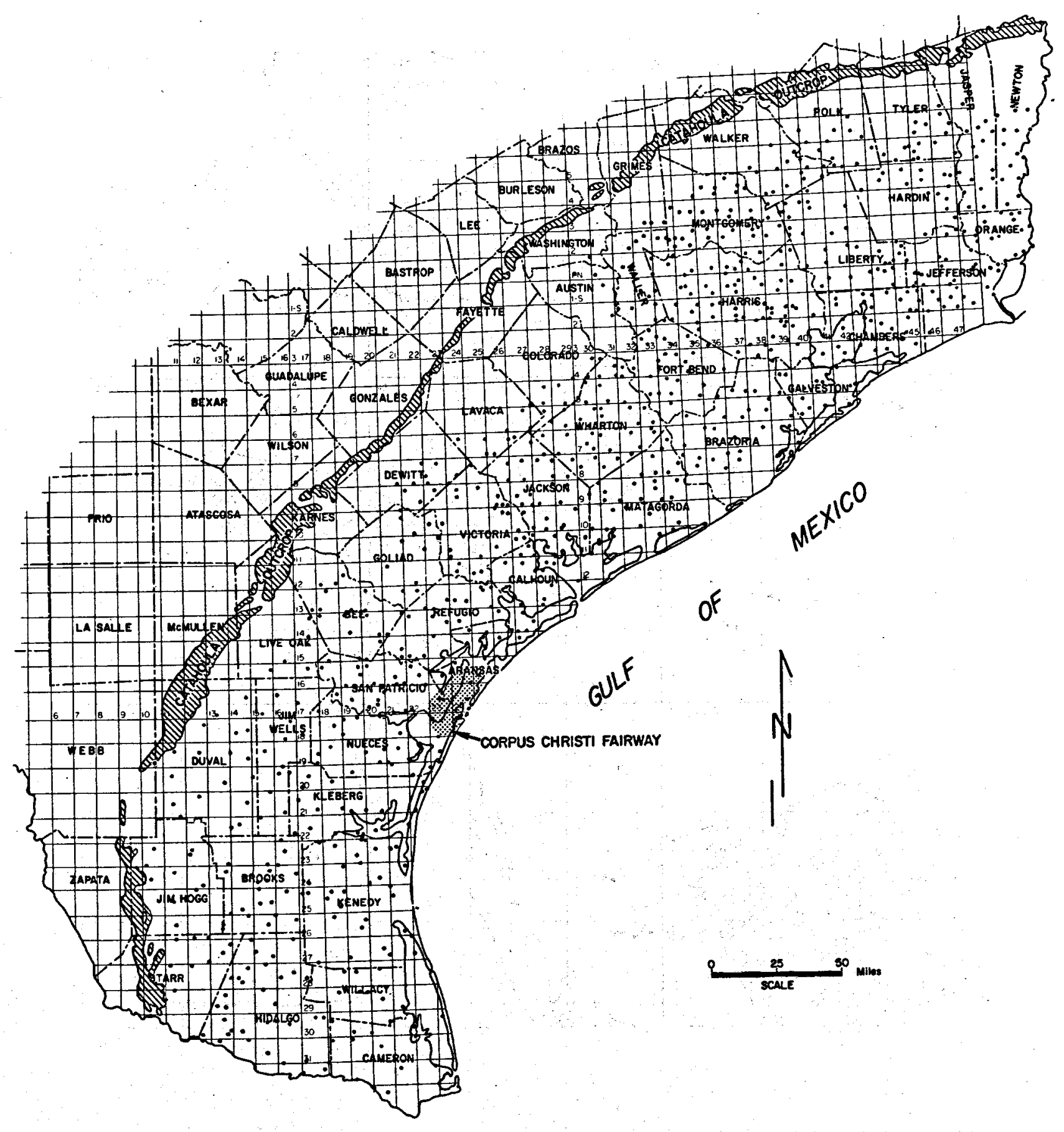

Figure 30. Corpus Christi Falrway. 


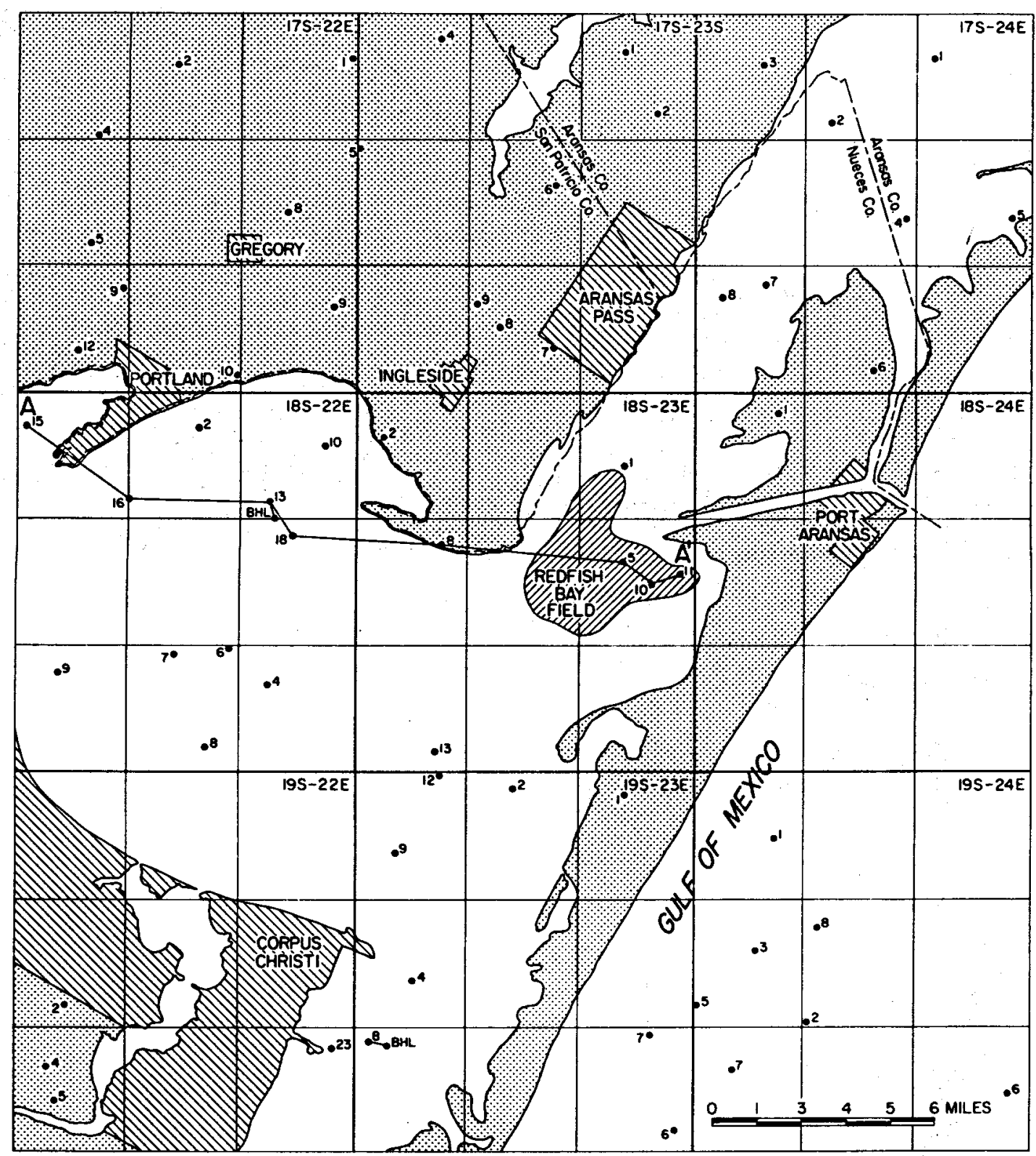

Figure 31. Well locations, Corpus Christi Fairway. Prospective sandstones in this fairway are within the Redfish Bay field which is transected by the dip section $A A^{\prime}$. 


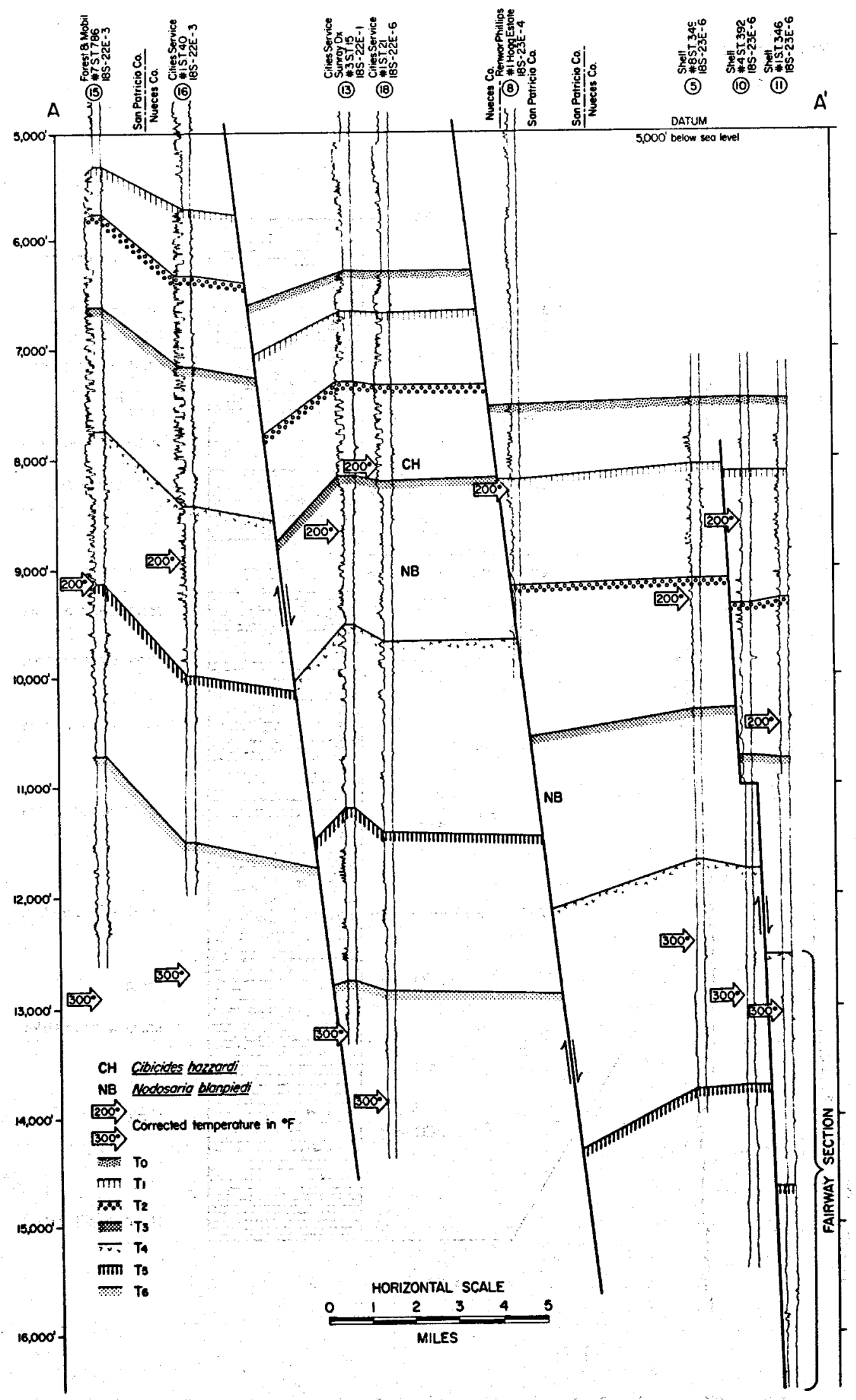

Figure 32. Dip section AA' across Corpus Christi Fairway. The $200^{\circ} \mathrm{F}$ isotherm occurs at the base of the main sand depocenter in the updip section. The $300 \mathrm{~F}$ isotherm occurs near the base of the section just above the T5 marker on the downdip end of the section. 
SHELL

No.I State Tract 346

18-23-6

(11)

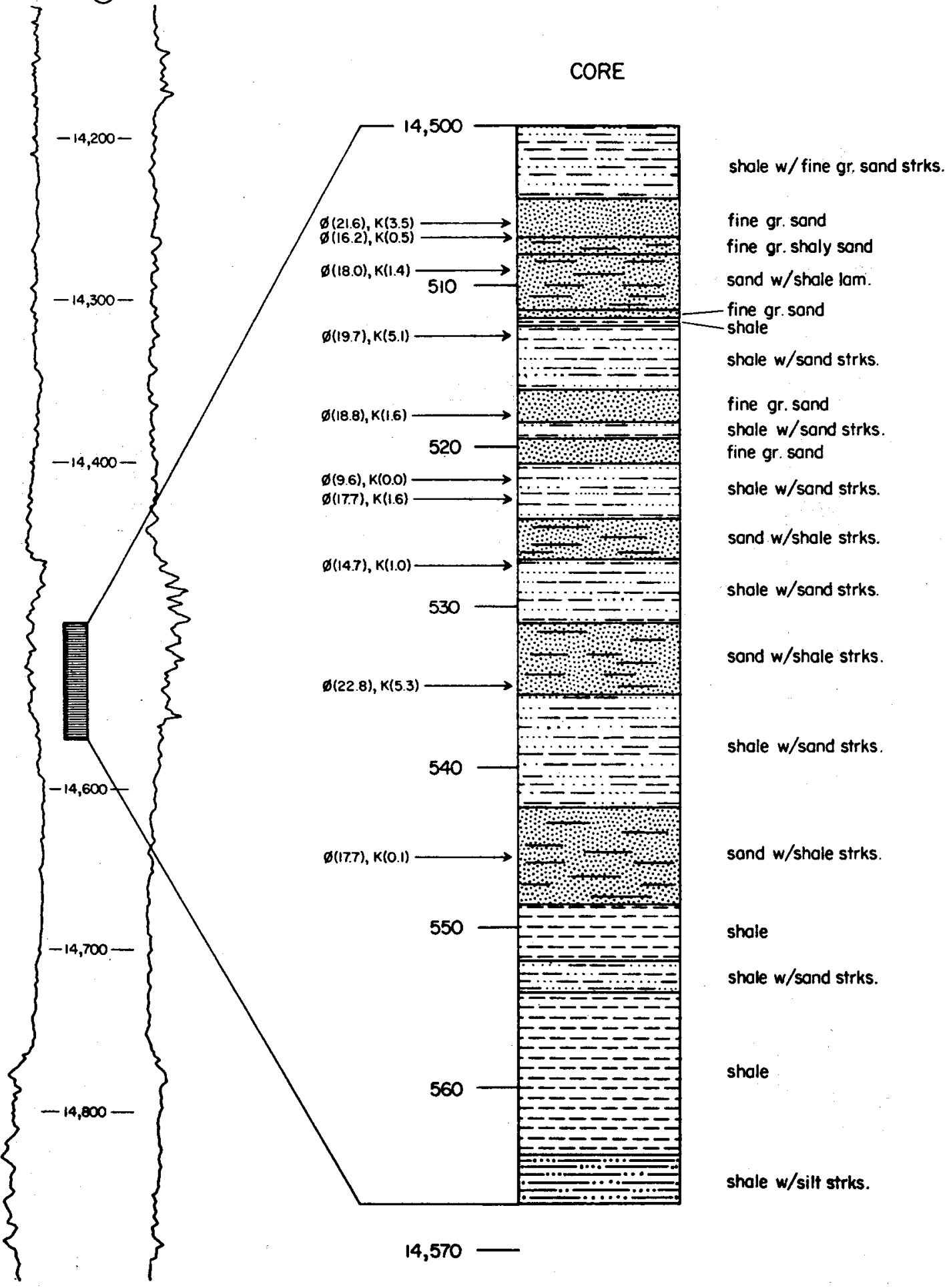

Figure 33. Electrical $\log$, core description, and core analysis from a sandstone unit in the Corpus Christi Fairway. 


\section{Matagorda Fairways}

The Matagorda Fairways contain sandstone beds with high fluid temperature, but reservoirs are thin and extremely limited in areal extent.

The Matagorda Fairways (fig. 34) were identified through the Middle Texas Frio study (Bebout, Agagu, and Dorfman, 1975) primarily as a result of high bottom-hole temperatures recorded from deep wells. It was recognized that the sandstones in this area are of less than adequate thickness, and that areal extent is unknown. However, more detailed correlation with dense well control in the Baer Ranch area (figs. 35 and 36) indicates that three sandstone units collectively are locally more than $\mathbf{4 0 0}$ feet thick. Sandstones $A, B$, and $C$ (fig. 36 ) from the Falcon Seaboard $A-1$ can be correlated to those of the Falcon Seaboard A-3, less than half a mile away; in this short distance the cumulative thickness of sandstone diminishes from 410 feet in A-1 to 260 feet in A-3. About 100 feet of sandstone is faulted out in A-3. Approximately 1 mile away in A-4, these sandstones constitute only 125 feet as a result of depositional thinning.

Several small growth faults cut the section of interest. Two faults cut the Falcon Seaboard Baer Ranch A-3 well (fig. 36)-one at 14,400 feet and the other at 15,140 feet. Displacements, 300 and 270 feet, respectively, are sufficient to cause significant disruption of thin, prospective reservoirs. Both faults cut the A-1 well shallower than the interval shown.
Bottom-hole temperatures recorded on well logs indicate that subsurface fluid temperature is significantly higher than $300^{\circ} \mathrm{F}$ in all three sandstone units (figs. 36 and 37 ).

Both the $A$ and $B$ sandstone units were extensively cored in the Falcon Seaboard Baer Ranch A-2 well (fig. 36). The 242 feet of core was analyzed at intervals of 0.5 to 1 foot. Core porosity of less than 20 percent and permeability of zero are most common; exceptions are shown on figure 36 . The top 4 feet of sandstone $A$ has permeabilities of 80 to 300 millidarcys: Twenty-five feet of sandstone $B$ has permeabilities of 15 to 700 millidarcys. In all cases, the most porous sandstone appears to be at the top of thin sandstone units.

In summary, the size of the reservoirs in the Matagorda Fairways is very limited both by . original distribution of the sands and by contemporaneous and later growth faults. Laterally, sandstone beds cannot be expected to persist with sufficient thickness for more than a few miles. Subsurface fluid temperatures are excellent and are higher than $340^{\circ} \mathrm{F}$ in all three sandstones. Core analyses indicate very high permeability in very thin intervals-commonly 1 to 10 feet thick. Because of limited lateral extent of reservoirs and lack of sufficient thickness of permeable sandstones, the Matagorda Fairways are not recommended as geothermal prospects. 


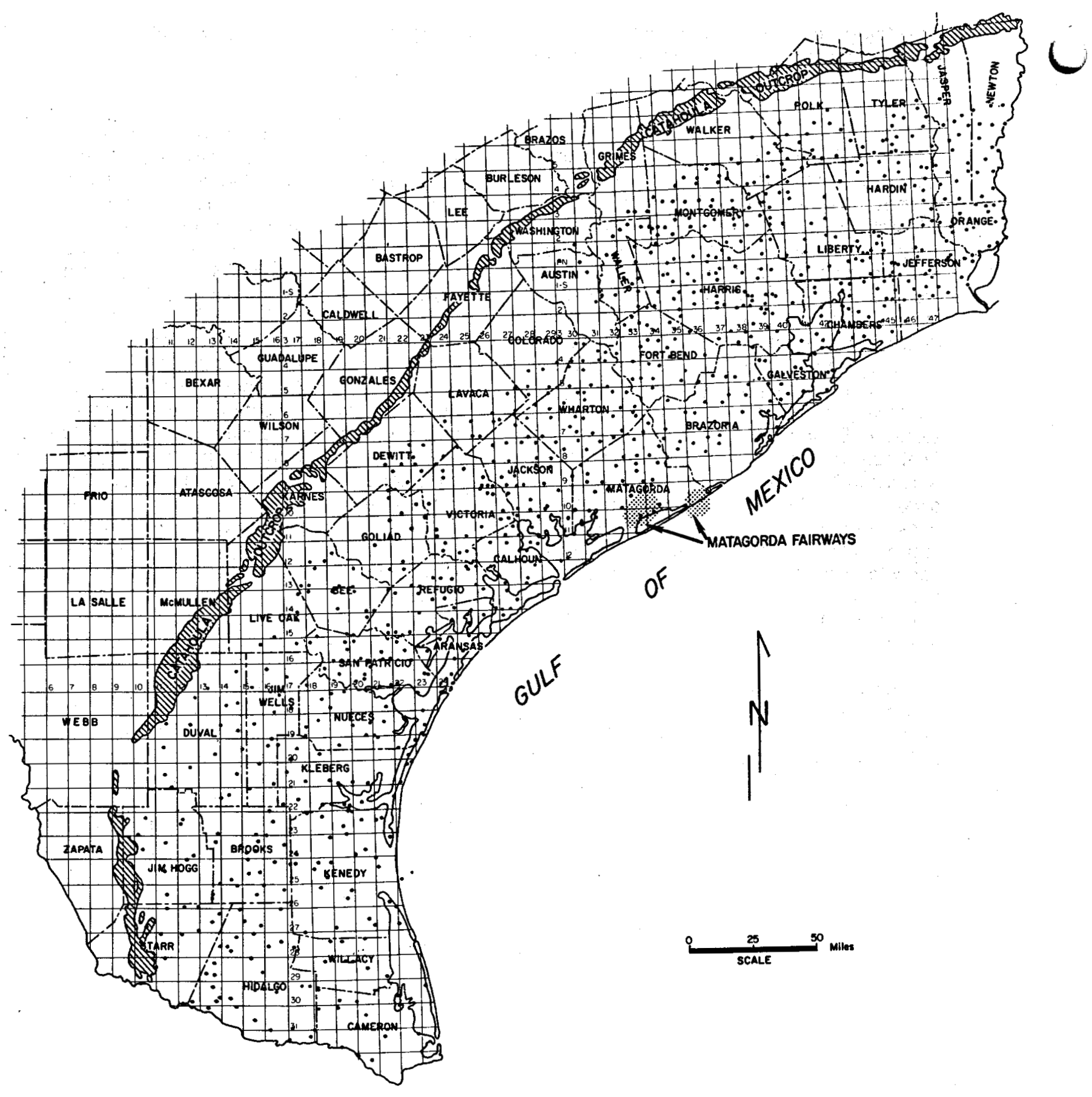

Figure 34. Matagorda Fairways. 


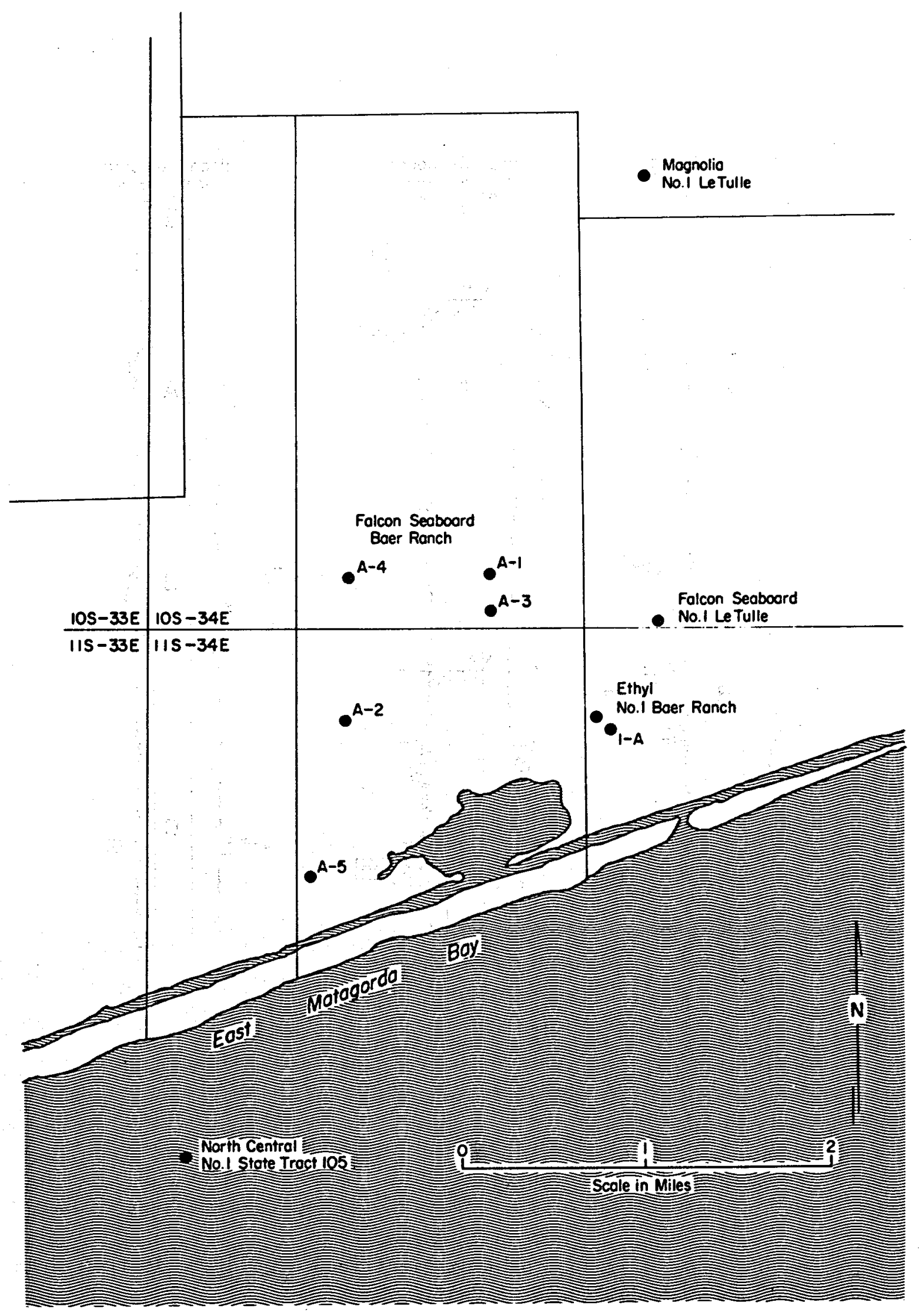

Figure 35. We11 locations, Baer Ranch field, Matagorda Fairway. 


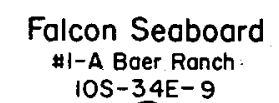

(7)

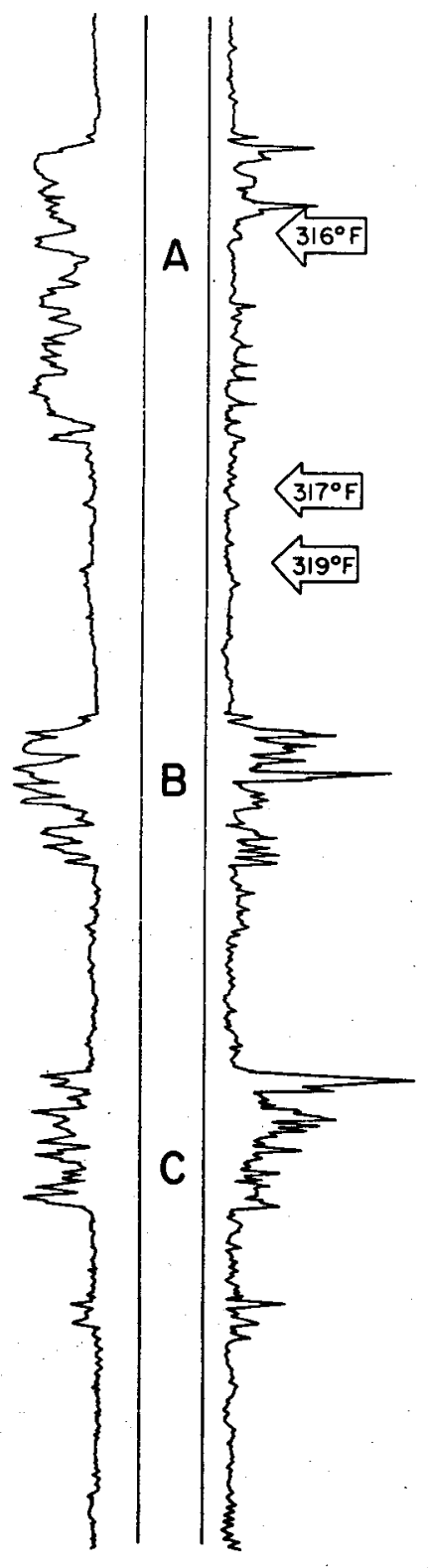

Falcon Seaboard

*3-A Baer Ranch

IOS-34E-9

(5)

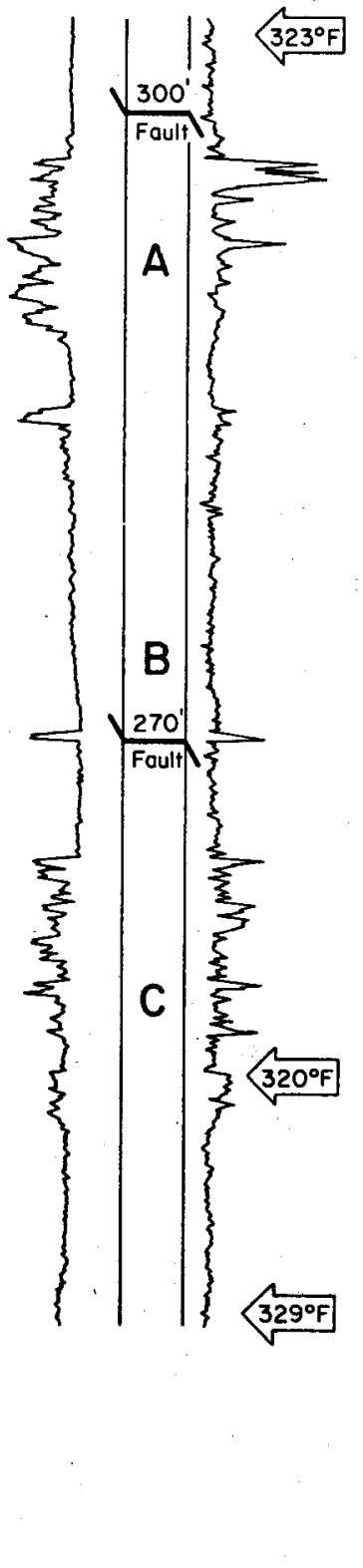

Falcon Seaboard

44-A Boer Ranch

$10 S-34 E-9$

(6)

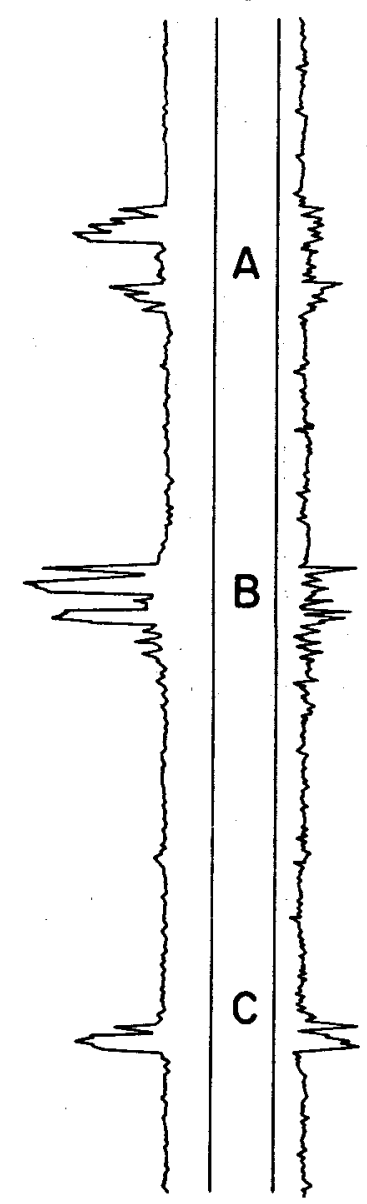

Figure 36. Sand distribution from electrical logs of wells from the Baer Ranch field, Matagorda Fairway. 


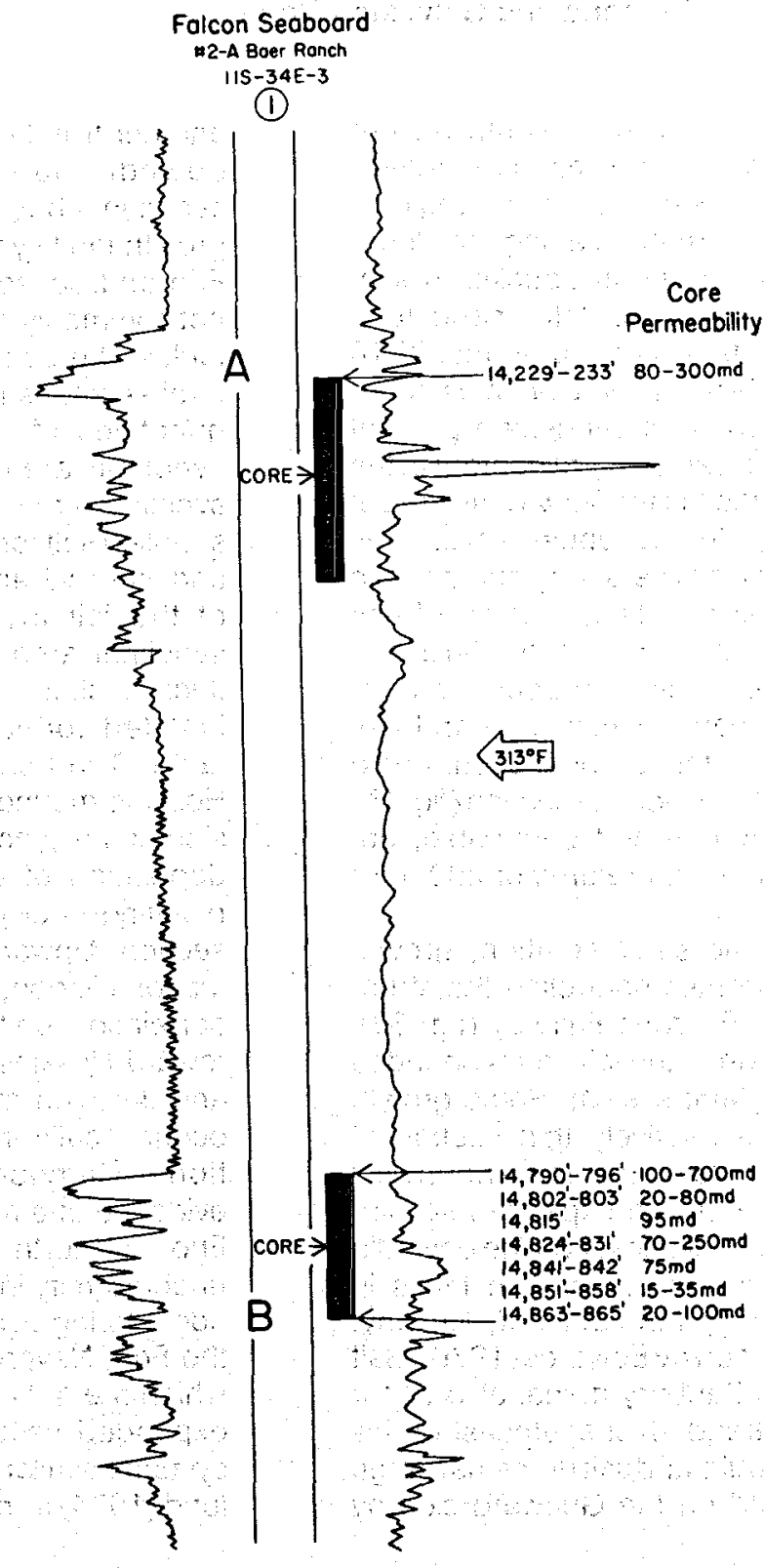

Figure 37. Core analyses from Falcon Seaboard No. 2-A Baer Ranch, Matagorda Fairway. 


\section{Brazoria Fairway-Structure}

Contemporaneous deltaic sedimentation, movement along growth faults, and salt dome formation resulted in accumulation of thick, permeable sandstone units in the Brazoria Fairway, located in Brazoria and Galveston Counties.

The Brazoria Fairway in southwestern Galveston and southern Brazoria Counties (fig. 38) was identified through the regional study of the Frio Formation along the Upper Texas Gulf Coast (Bebout, Loucks, Bosch, and Dorfman, 1976). Potential sandstone reservoirs in this fairway occur in the T5-T6 correlation unit (Anomalina bilateralis zone) and are indicated on a sandstone percent map (fig. 16) by the 20-percent contour in the north-central portion of the fairway, an area of thick sandstone. In the Upper Texas Gulf Coast report, correlative sandstone beds in two wells were misidentified, because of lack of control, as occurring in the T4-T5 and T1-T2 correlation units (Bebout, Loucks, Bosch, and Dorfman, 1976, figs. 47 and 48). Massive Frio sandstones which occur updip and shallower on the regional section (fig. 15) are extremely porous and permeable, but they contain fluid temperatures of $200^{\circ} \mathrm{F}$ or less (fig. 16).

Massive deltaic sedimentation, growth faults, and salt domes controlled the structural style in the Brazoria Fairway (fig. 39). The northwest side of the fairway is bounded by an extensive fault system. Some growth faults separate a relatively thin section of sandstone and shale on the updip northwest side of the fault from an expanded section several thousand feet thicker on the downdip or southeast side. Similar growth faults in spectacular outcrops in Svalbard, Norway, have been described by Edwards (1976). Salt domes, such as Danbury dome, also occur along this fault trend. Just southeast of this trend of growth faults and salt domes is a large syncline bounded on the Gulfward side by another trend of faults and salt domes. This downdip fault system displaces Frio sediments but, for the most part, was not a growth fault system during deposition of the Frio, and, consequently, the Frio section does not commonly expand on the downdip side of faults. The complex depositional and structural setting is the result of loading by large quantities of shale and sandstone in the synclinal area. Salt withdrawal from the synclinal area, as a result of this loading, supplied salt for the growth of Danbury dome and other salt anticlines on the northwest side of the fairway. Rapid subsidence in the synclinal area allowed accumulation of a thick section of shale and sandstone and initiated formation of associated growth faults. The trend of salt anticlines, such as Hoskins mound, and faults on the downdip side of the syncline, probably formed during deposition of post-T5 Frio deposits, thus resulting in displacement of only the T5-T6 section. Upwarp of the Frio and older formations is documented by the fact that Frio correlation units occur shallower downdip toward Hoskins mound, and that Vicksburg and Jackson micropaleontological markers occur locally in anomalously shallow positions. Campbell (1941) offered seismic evidence of a major unconformity within the Frio just north of the Hoskins Mound. This unconformity indicates movement of the salt ridge during deposition of the post-T5 part of the Frio. Nevertheless, many of these faults which are not accompanied by downthrown expanded sections may be collapse-fault systems similar to those described by Seglund (1974) from the Gulf Coast of Louisiana. 


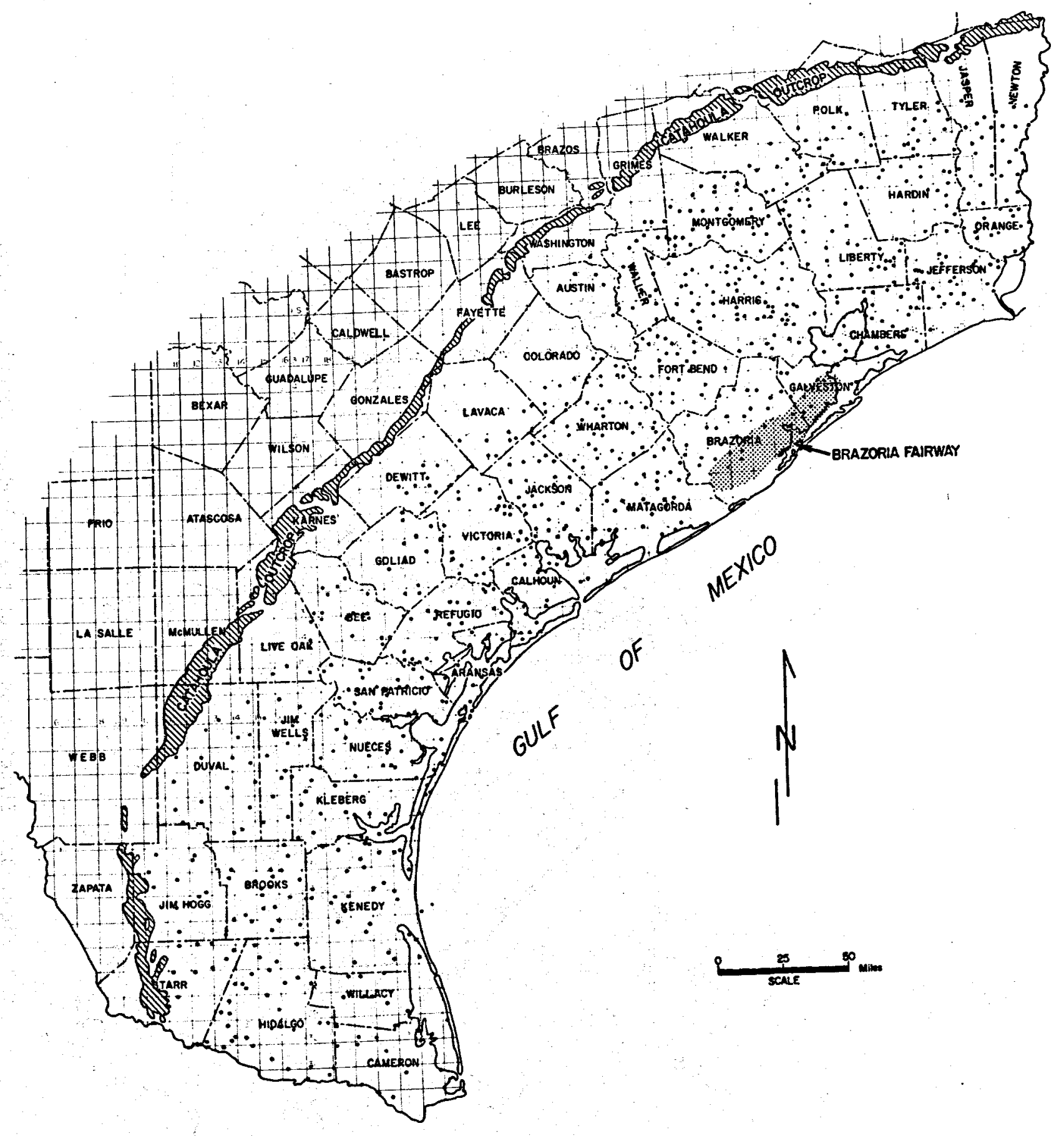

Figure 38. Brazoria Fairway. 


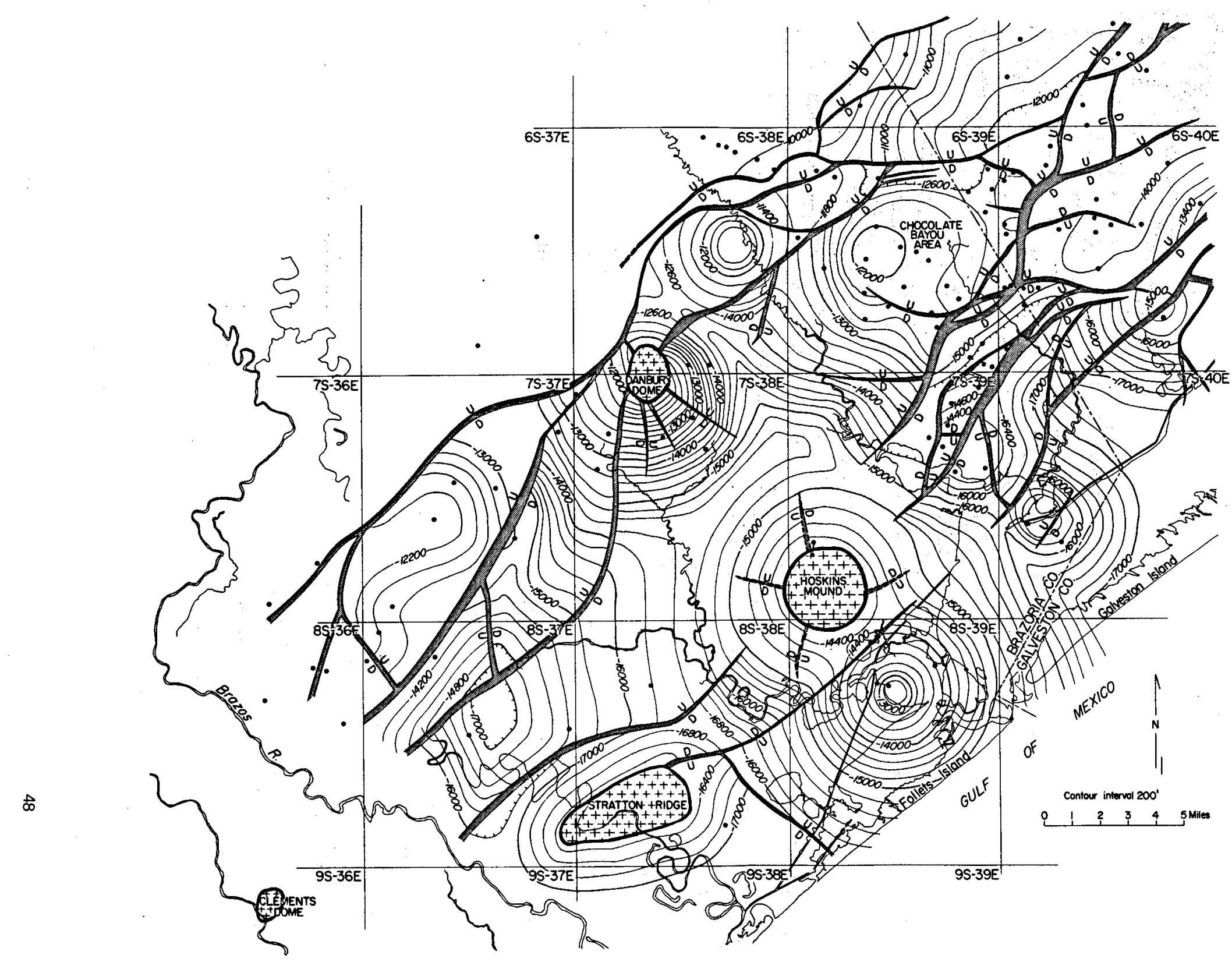

Figure 39. Structure on top of the T5 marker, Brazoria Fairway. 


\section{Brazoria Fairway-Depositional Style}

Repetition of thick permeable sandstone units in the upper part of seven depositional sequences in the Brazoria Fairway resulted in the accumulation of several hundred feet of potential geothermal reservoir sandstone displaying fluid temperature greater than $300^{\circ} \mathrm{F}$.

Structural sections across the fairway (figs. 40 to 43 ) show the complexity resulting from the formation, contemporaneously with deposition, of growth fault and salt dome trends. Correlation of individual sandstone beds within fault blocks is considered extremely good; however, correlation across major growth faults is difficult and, in some cases, possible only using micropaleontological markers. The micropaleontological zones are very reliable and occur uniformly throughout the fairway. The fault and salt dome trend along the southeast side of the fairway is shown on the downdip third of section $A A^{\prime}$ (fig. 41) and on the downdip half of section BB' (fig. 42). The Brazoria Fairway lies between these structurally complex zones (between the Humble No. 1 Vieman well updip and Hoskins mound downdip on section $A A^{\prime}$ ) in the large salt-withdrawal syncline (fig. 41 ). $\cdots$

Prospective reservoirs occur below the T5 marker where there is a marked increase in thickness of the section and in sandstone percentage: Maximum sand thickness occurs in seven major shale-sandstone depositional sequences (Frazier, 1974) in the Humble No. 1 Skrabanek just south of Danbury dome (fig. 41). These cyclic sequences are recognizable, but they are considerably thinner northeastward in the Texas Company and Fort Bend No. 2 Houston Farms Development well and in Chocolate Bayou field (fig. 43). Shallower Frio correlation units, To to the top of T5, are characterized by dominant shale with scattered, thin sand- stone beds. Thus, the Frio deposits in the Brazoria Fairway reflect two major depositional episodes (Frazier, 1974) (fig. 44)-one from the top of the Frio (TO) downward to the top of T5, and the other from T5 downward to the base of the formation. The top of the Frio is marked by a very distinctive, thin, resistive zone which can be easily picked on electrical logs, and which probably is either a glauconite or volcanic ash layer.

The top of the geopressure zone is at approximately 10,000 feet below sea level. The $200^{\circ} \mathrm{F}$ isotherm occurs in the fairway area at a depth of 8,200 feet. The $300^{\circ} \mathrm{F}$ isotherm occurs in the prospect at a depth of 13,500 feet, just above the T5 marker. Massive sandstones occur below this isotherm in the Humble No. 1 Skrabanek, south of the Danbury dome, and in wells of the Chocolate Bayou field.

In summary, the Brazoria Faırway is 20 miles long and 10 miles wide. Reservoir thickness varies from more than 1,200 feet southwest in the Danbury dome area to less than 200 feet northeast at Chocolate Bayou. Prospective sandstone reservoirs all occur with the T5-T6 unit, which to the southwest contains temperatures in excess of $300^{\circ} \mathrm{F}$. To the northeast, this unit is structurally shallower, however, and the $300^{\circ} \mathrm{F}$ isotherm occurs lower within the T5-T6 unit.

The Brazoria Fairway is recommended as the prime area within the Frio Formation for the location of a geothermal test well site, and the Austin Bayou Prospect has been developed within this fairway. 


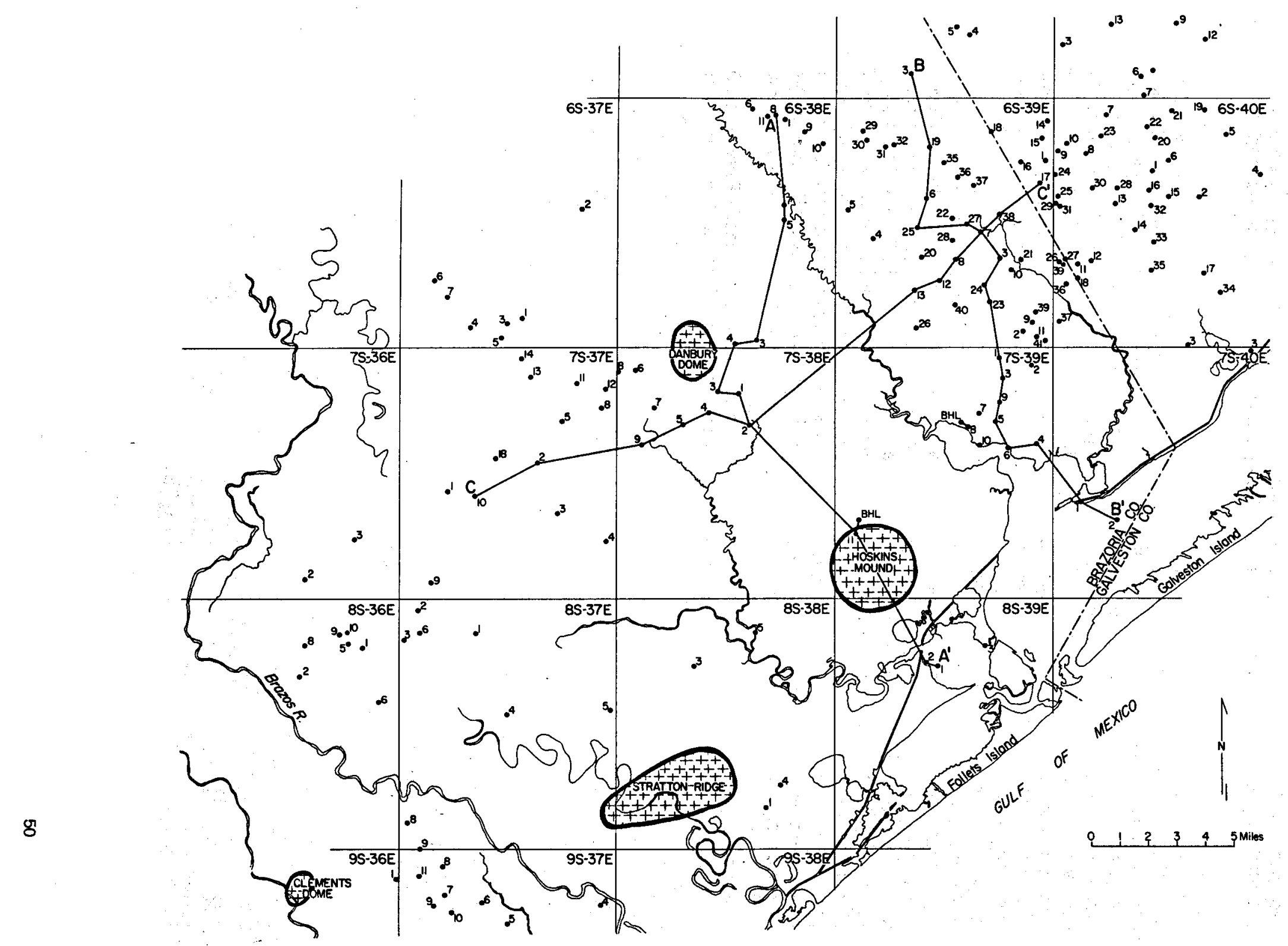

Figure 40. Location of Frio wells and structural sections $A A^{\prime}, B^{\prime} B^{\prime}$, and $C C^{\prime}$. 


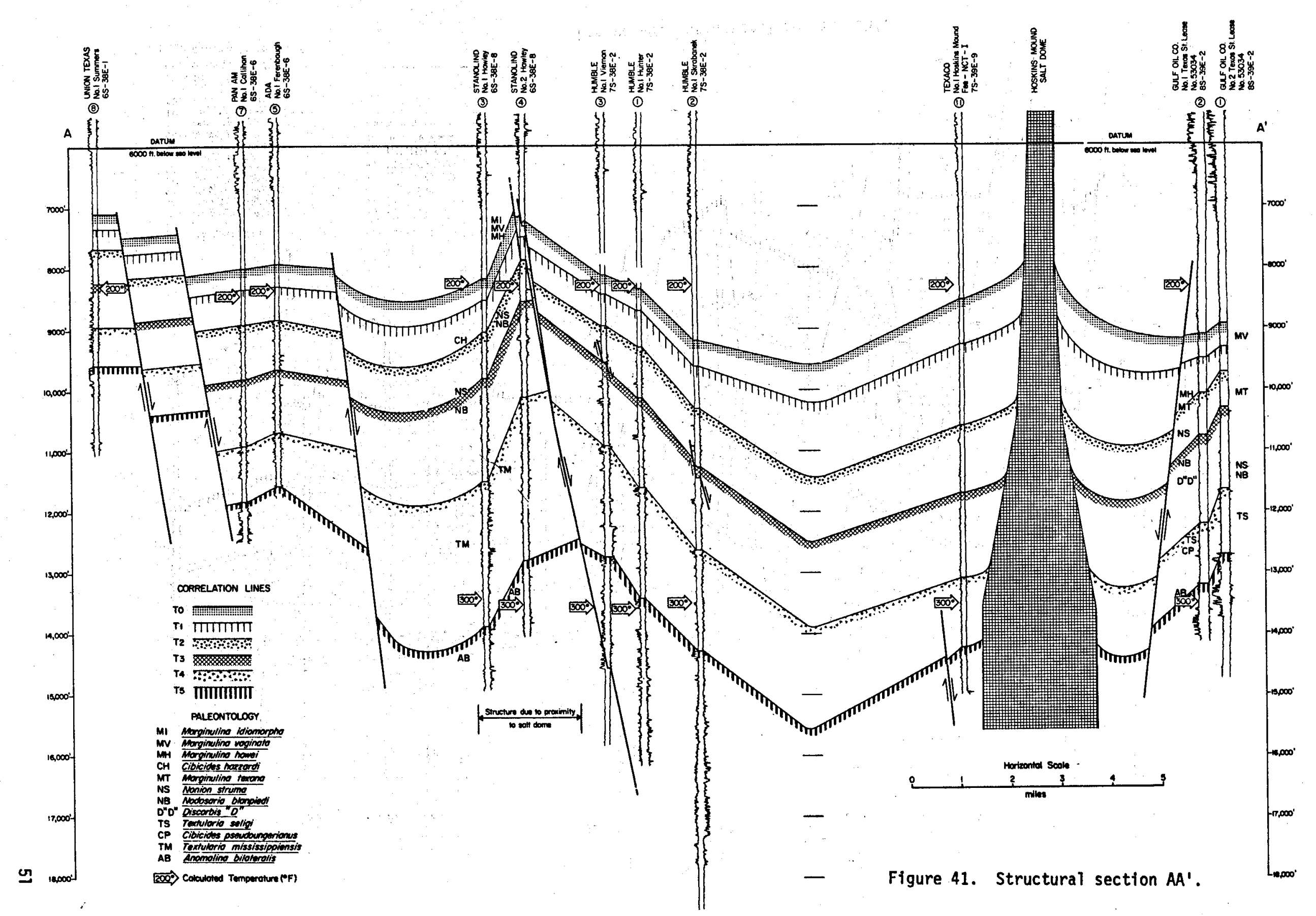




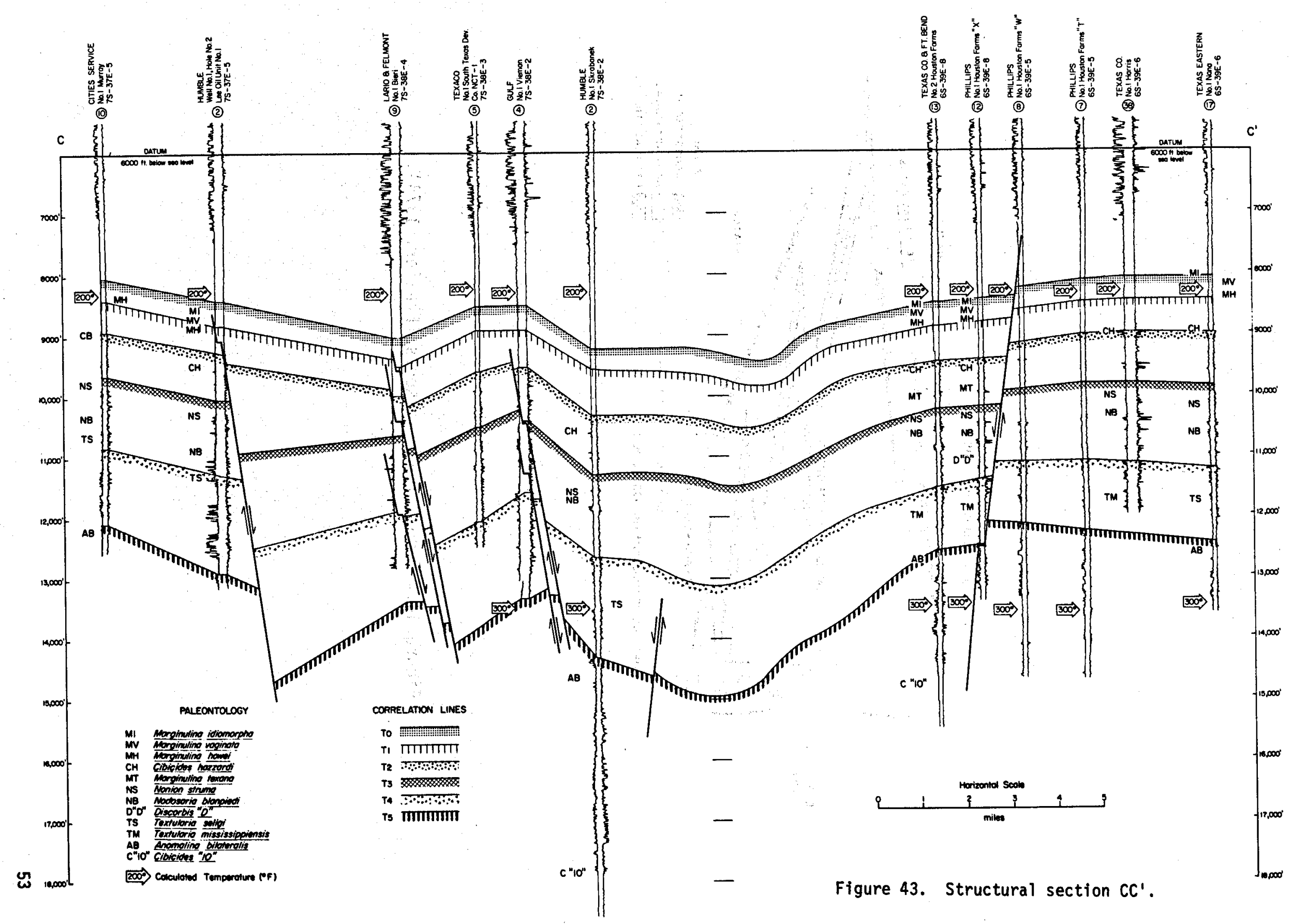




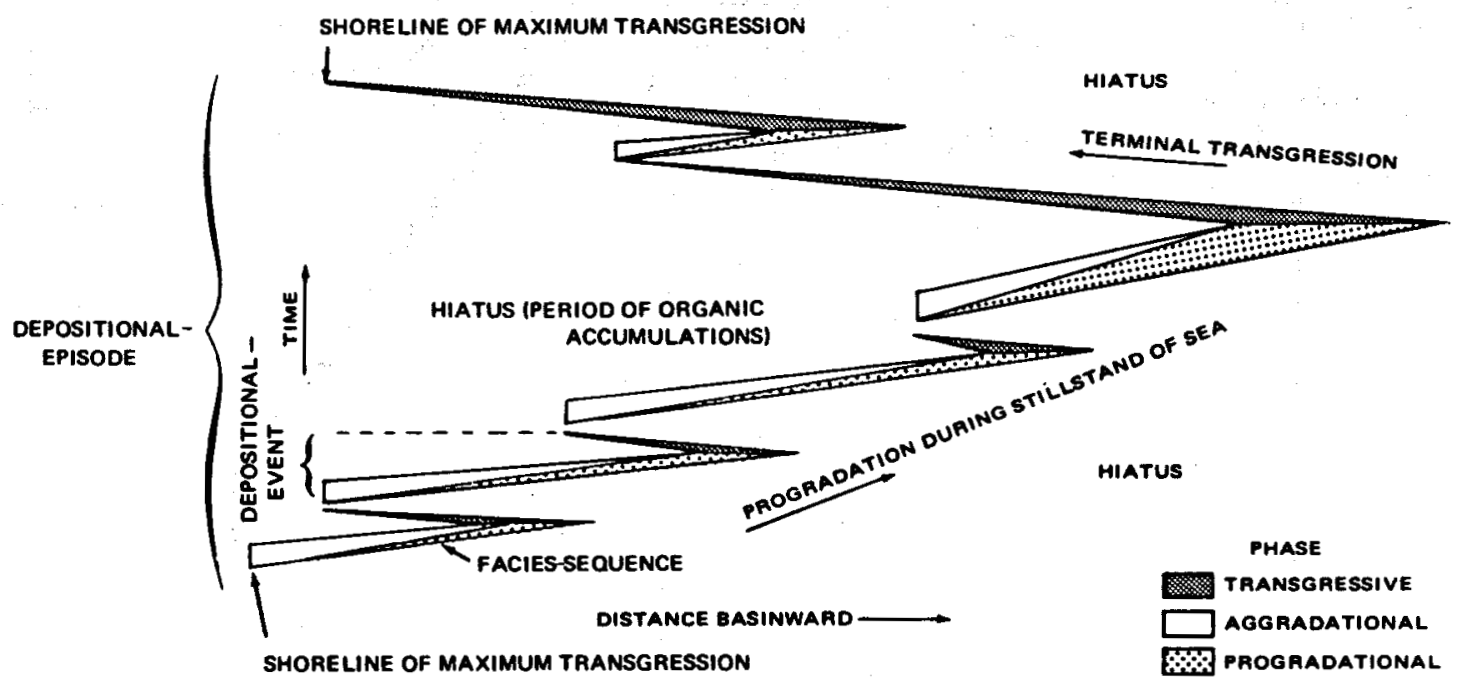

Figure 44. Depositional episodes (Frazier, 1974). 


\section{Sandstone Consolidation History-The Key to Origin of Porosity and Permeabllity}

The Frio sandstone consolidation history consists of a number of stages of cementation and leaching which ultimately controlled the final porosity and permeability within the deep sandstone reservoirs.

Preliminary studies of sandstone consolidation stages (compaction, cementation, and leaching) of deep-subsurface Frio reservoirs along the Texas Gulf Coast indicate that sandstone reservoirs have undergone a complex history. Pores in deep sandstone reservoirs are not simply the result of preservation of primary interparticle porosity but actually consist dominantly of secondary leached-grain porosity. Sandstones in these deep reservoirs are composed of quartz, feldspar (plagioclase and orthoclase), and volcanic and carbonate rock fragments. Relative proportions of these rock components vary from the Upper to the Lower Texas Gulf Coast (fig. 45). Frio sandstones of the Upper Texas Gulf Coast contain more quartz and less feldspar and volcanic rock fragments (quartzose feldspathic volcanic litharenite), and those of the Lower Texas Gulf Coast are higher in volcanic rock fragments and feldspar than in quartz (feldspathic litharenite). Carbonate rock fragments are more common along the Lower Texas Gulf Coast and decrease in abundance northward (Lindquist, 1976). Composition of Frio sandstones of the Middle Texas Gulf Coast is intermediate between those of the Lower and Upper Texas Gulf Coast. This regional change in composition is independent of grain size (fig. 46). The Catahoula Formation, the updip outcropping equivalent of the Frio, exhibits this same regional compositional change (Galloway, 1977).

Several stages of cementation and leaching contributed significantly to development of deep sandstone reservoirs (figs. 47 and 48). Most stages of consolidation at shaallow to moderate depths result in destruction of the porosity through compaction and precipitation of calcite and quartz cements. Extreme examples of this destruction are poikilotopic calcite and massive quartz cements which reduce porosity to less than 5 percent. At depths of approximately 9,000 to 11,000 feet, the major stage involving leaching of feldspar, volcanic and carbonate rock fragments, and calcite cement occurs. Consequently, the porosity destruction stage of shallower sections is reversed to a porosity development stage; this is the deep stage of reservoir development. Below approximately 11,000 feet, leached porosity is reduced by precipitation of kaolinite and Fe-rich carbonate cements.

Reservoir quality of the Frio sandstones also varies on a regional scale. Along the Lower Texas Gulf Coast, core permeability in sandstone beds deeper than 13,000 feet averages 1 to 2 millidarcys. Lindquist (1976) concluded that most of the deep reservoirs are cemented with late-forming kaolinite and Fe-rich calcite and dolomite (fig. 47). Northeastward along the Upper Texas Gulf Coast, on the other hand, permeability in deep sandstones ranges up to hundreds of millidarcys. This higher permeability is interpreted as the result of the less well-developed late carbonate cementation stage. Compositional variation is inferred to be a major factor controlling reservoir quality of the Frio sandstones. For example, abundant carbonate rock fragments along the Lower Texas Gulf Coast probably provided nuclei for deep carbonate cement which destroyed much of the porosity of these sandstones, whereas this type of cement is less well developed northeastward along the Upper Texas Gulf Coast where carbonate rock fragments are rare. This relationship suggests positive correlation between carbonate rock fragments and carbonate cement.

Preliminary rock consolidation studies of the Chocolate Bayou field area, Danbury dome area, and Lower Texas Gulf Coast show variations in intensities of the various diagenetic stages (fig. 47).

Chocolate Bayou field area-In the shallow and intermediate subsurface, to a depth of approximately 9,000 feet, normal compaction and systematic early stages of cementation reduced porosity to less than 15 percent. At depths of 8,000 to 11,000 feet, the leaching stage increased porosity up to 30 percent. Much of the secondary porosity was preserved at greater depths, but some kaolinite and Fe-rich carbonate cement were deposited, reducing average porosity to 25 percent or less. 
Danbury dome area-Early rapid subsidence prevented early stage cementation and resulted in greater than normal burial compaction. During later stages of compaction at intermediate depths, massive quartz cementation aided in reducing porosity to less than 10 percent. Massive quartz cementation probably hindered development of secondary porosity at greater depths. The final result is the absence of porous reservoirs in these compacted and cemented sandstones.

Lower Texas Gulf Coast (Lindquist, 1976)-Normal compaction and abundant early sparry calcite cementation occurred in the intermediate depth zone and resulted in reduction of porosity to less than 10 percent. In contrast to the less soluble quartz cement of the Danbury area, the sparry calcite and feldspars were leached, and up to 30-percent porosity resulted during the deeper leaching stage. Following this leaching stage, kaolinite and Fe-rich carbonate and zeolite cements drastically reduced porosity to less than 15 percent. The higher content of carbonate rock fragments in this area, compared to areas to the north, may be the reason for this greater cementation.

Further investigations are needed to determine the factors which control local and regional development of porosity and permeability in deep subsurface geopressured geothermal reservoirs. A study of sandstone consolidation history from cores throughout the Texas Gulf Coast is essential to any continued search for geothermal reservoirs. Such studies are required to determine whether reservoirs of sufficient quality to produce large quantities of water for substantial periods of time do exist at depths necessary to reach $300^{\circ} \mathrm{F}$ temperatures.

*Figure 48, containing full-color photomicrographs, is not included in this report. 


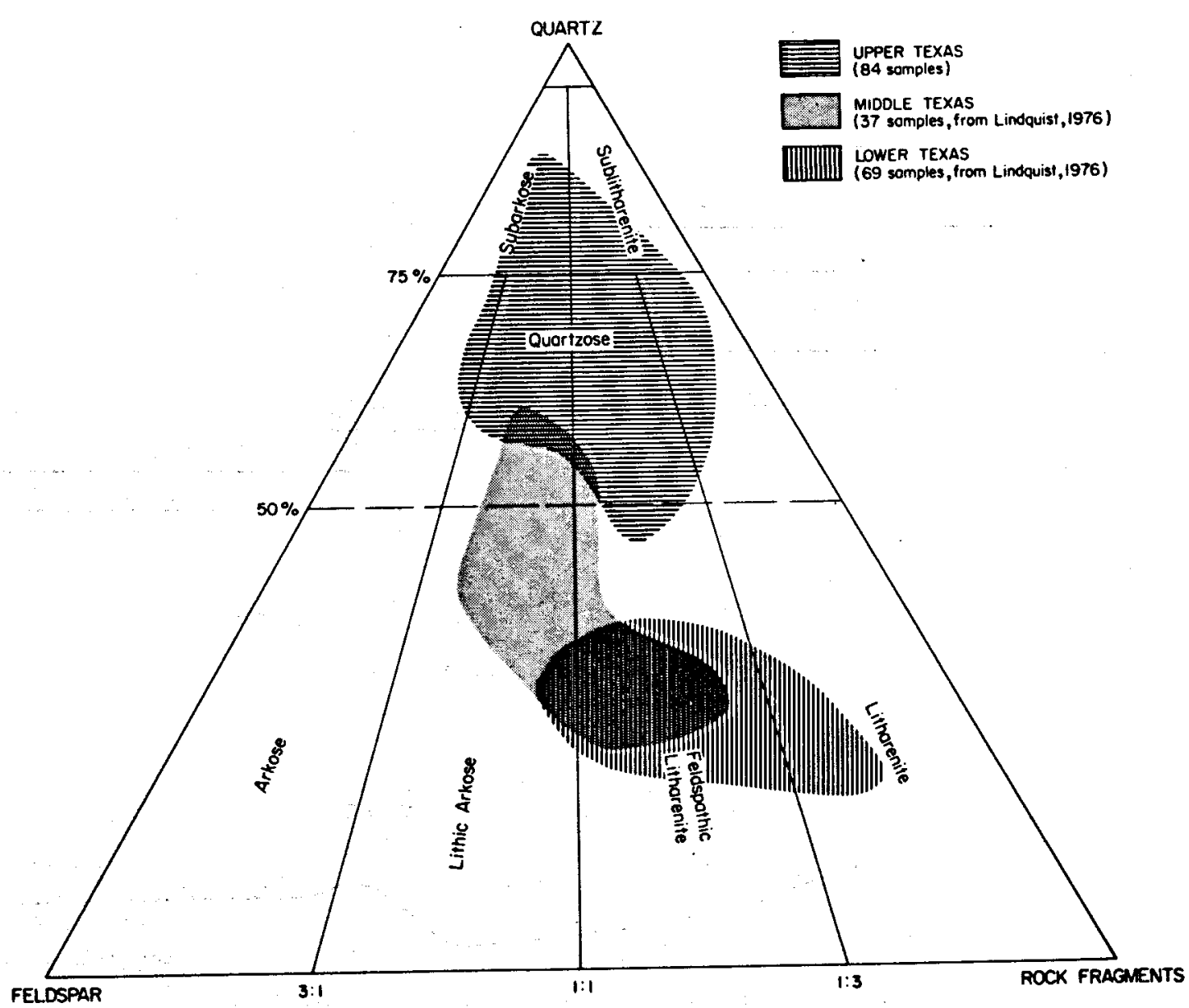

Figure 45. Sandstone composition. Sandstone classification after Folk, 1968.

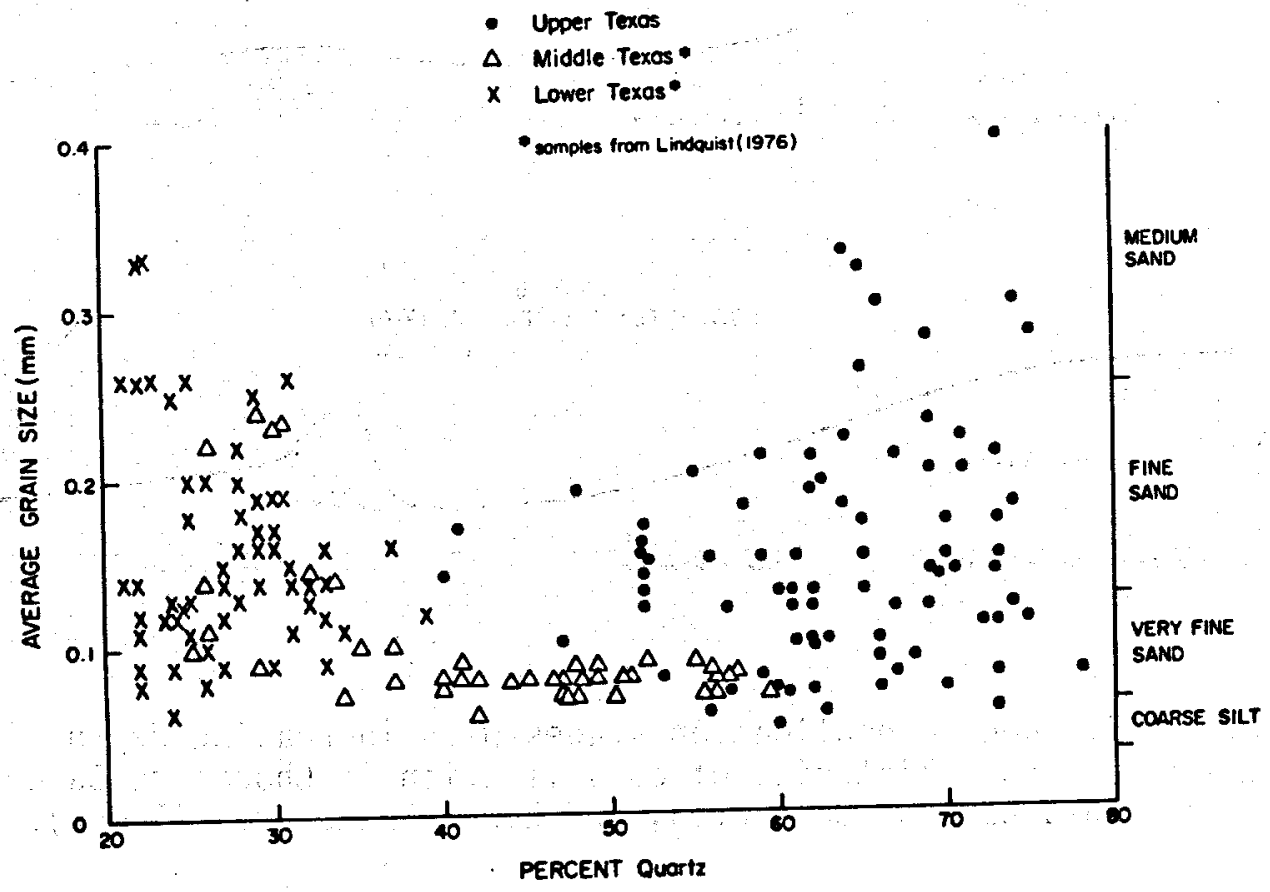

Figure 46. Relationship of percentage of quartz to average grain size between Lower, Middle, and Upper Texas Gulf Coast. 


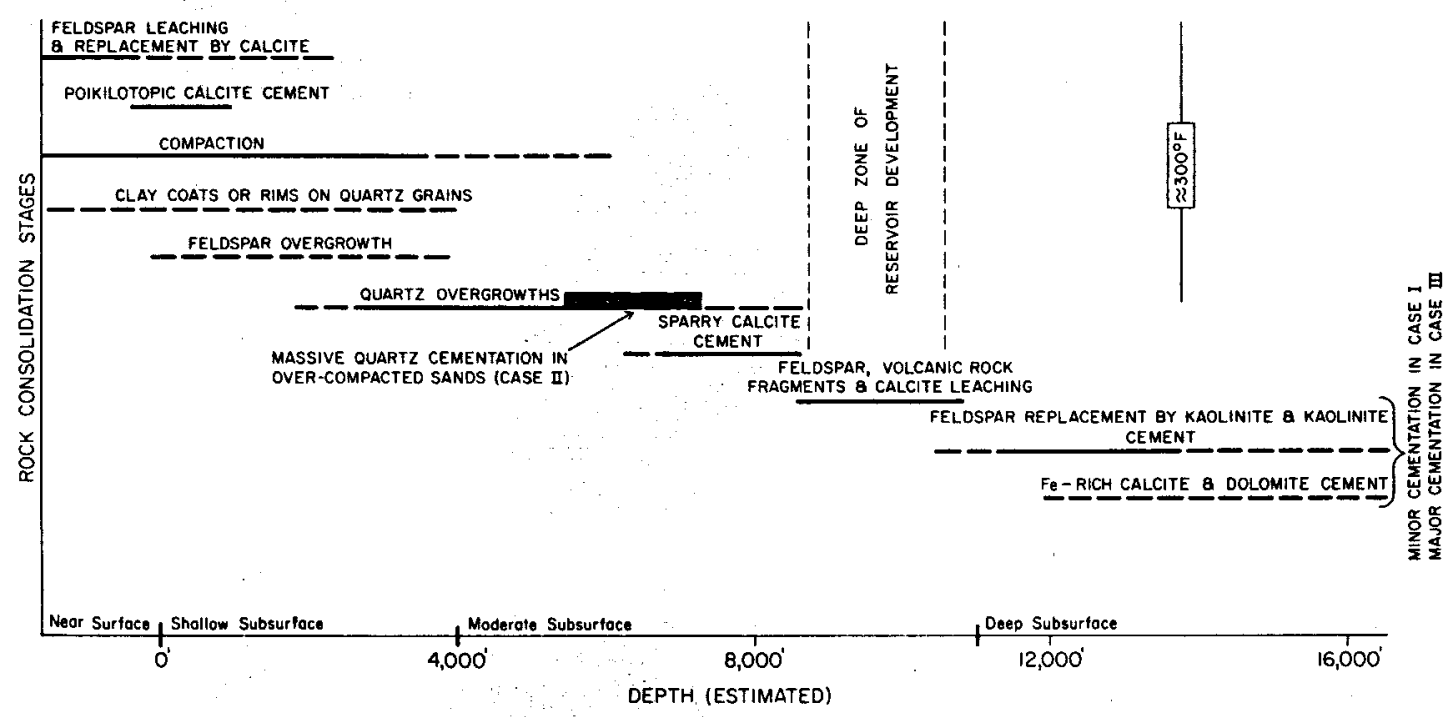

CASE I

UPPER TEXAS - CHOCOLATE BAYOU / ALTA LOMA FIELD AREA

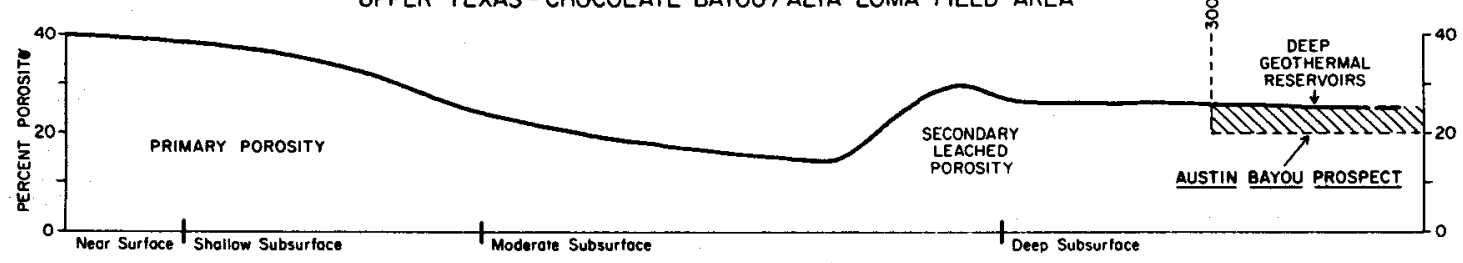

CASE II

UPPER TEXAS - DANBURY DOME AREA

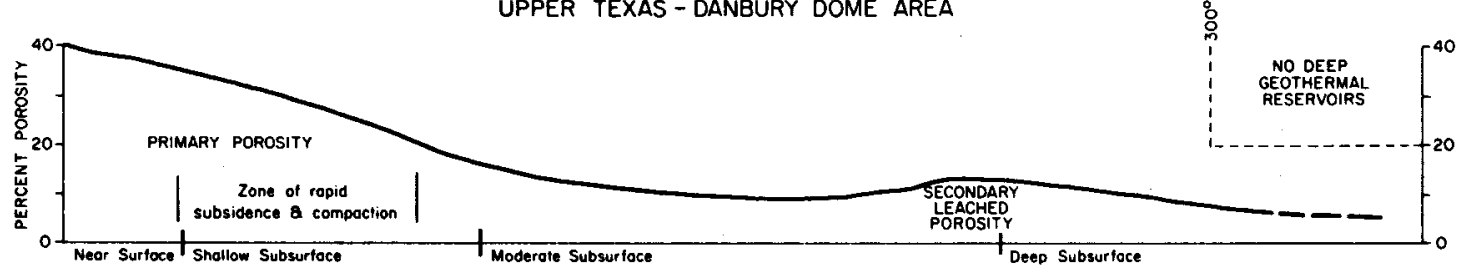

CASE III

LOWER TEXAS (LINDQUIST, 1976)

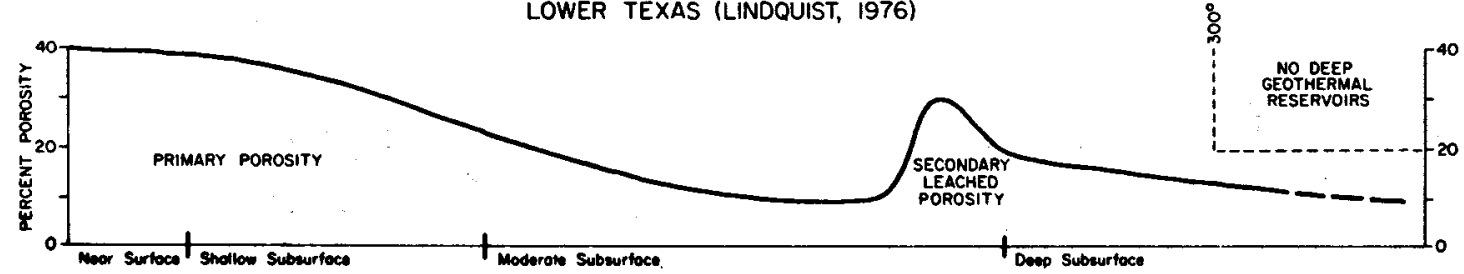

Figure 47. Rock consolidation stages with increasing depth of burial (upper) and case histories of consolidation in Chocolate Bayou/Alta Loma field areas, Danbury dome area, and Lower Texas area (lower). 


\section{Summary}

A prospective geothermal well site which will have $\mathbf{2 5 0}$ to $\mathbf{3 5 0}$ feet of reservoir sandstone with core permeabilities between 40 and 60 millidarcys and fluid temperatures from $300^{\circ}$ to $350^{\circ} \mathrm{F}$ has been located within the Austin Bayou Prospect.

The Austin Bayou Prospect is located within the Brazoria Fairway in a syncline between Chocolate Bayou field on the northeast and Danbury dome on the southwest (fig. 49). The prospective reservoirs lie within the T5-T6 correlation unit (Anomalina bilateralis zone) at depths greater than 12,000 feet in the Chocolate Bayou field, and deeper than 15,000 feet between Danbury dome and the Hoskins mound along the axis of the syncline (fig. 49). Major faults occur on either side of the syncline, and small radial faults extend from the domes into the syncline. The few wells which have been drilled along the edge of the syncline do not show evidence of faulting. Apparent lack of faulting is supported by a seismic line that crosses the prospect area in a strike (northeast) direction (fig. .50). Furthermore, a model of salt-withdrawal basins by Seglund (1974) predicts a lack of large-scale faults in this type of basin (fig. 51).

Maximum thickness of sand (fig. 52) accumulated approximately 2 to 3 miles from the south and east side of Danbury dome about 1 mile updip from the axis of the syncline. The sandstone beds thin rapidly to the northwest onto the dome and against a complex of growth faults. The sandstones thin and grade into a thick, dominantly shale section downdip to the southeast. Along strike to the northeast, the entire section thins onto the Chocolate Bayou structure, a more positive area during deposition of the T5-T6 section. The area of sandstone pinchout onto this structure should be considered prospective for hydrocarbon stratigraphic traps.

Core porosity and permeability are highest northeastward in Chocolate Bayou field (20- to 25-percent porosity, hundreds of millidarcys permeability) and decrease to the southwest where 10- to 15-percent porosity and less than 10 millidarcys permeability occurnear Danbury dome. Rapid subsidence near the salt dome prevented the formation of early fabric-freezing cement and thus allowed considerable compaction during burial; consequently, porosity is very low in this thick sandstone section. To the northeast, on the other hand, deposition occurred on a more positive area and sands were reworked and partially cemented very early in their burial history.

Temperature of the reservoir interval increases southwestward as a result of southwest dip of the T5-T6 unit in the syncline. Approximately midway between the Chocolate Bayou field and Danbury dome. the T5 marker is deeper than 13,500 feet, the depth at which fluid temperatures are greater than $300^{\circ} \mathrm{F}$.

The prospective well site (fig. 52) has been located on the basis of the best possible combination of sand thickness, permeability, and temperature. Near Danbury dome, the cumulative sandstone thickness is high, individual sandstone beds are relatively thin, and the fluid temperatures are high; however, permeability is very low. Northeastward, in the Chocolate Bayou field, the net sandstone is low, individual sandstone units are thick, temperatures are low, and permeability is high. The prospective well site has been located between the areas where net sandstone thickness reaches 800 to 900 feet. Thirty to 35 percent of the net sandstone will have adequate permeability; average core permeability should be between 40 and 60 millidarcys. Fluid temperature is expected to be $300^{\circ} \mathrm{F}$ at the top of the sand interval, 13,500 feet, and $350^{\circ} \mathrm{F}$ at the base, 16,500 feet. 


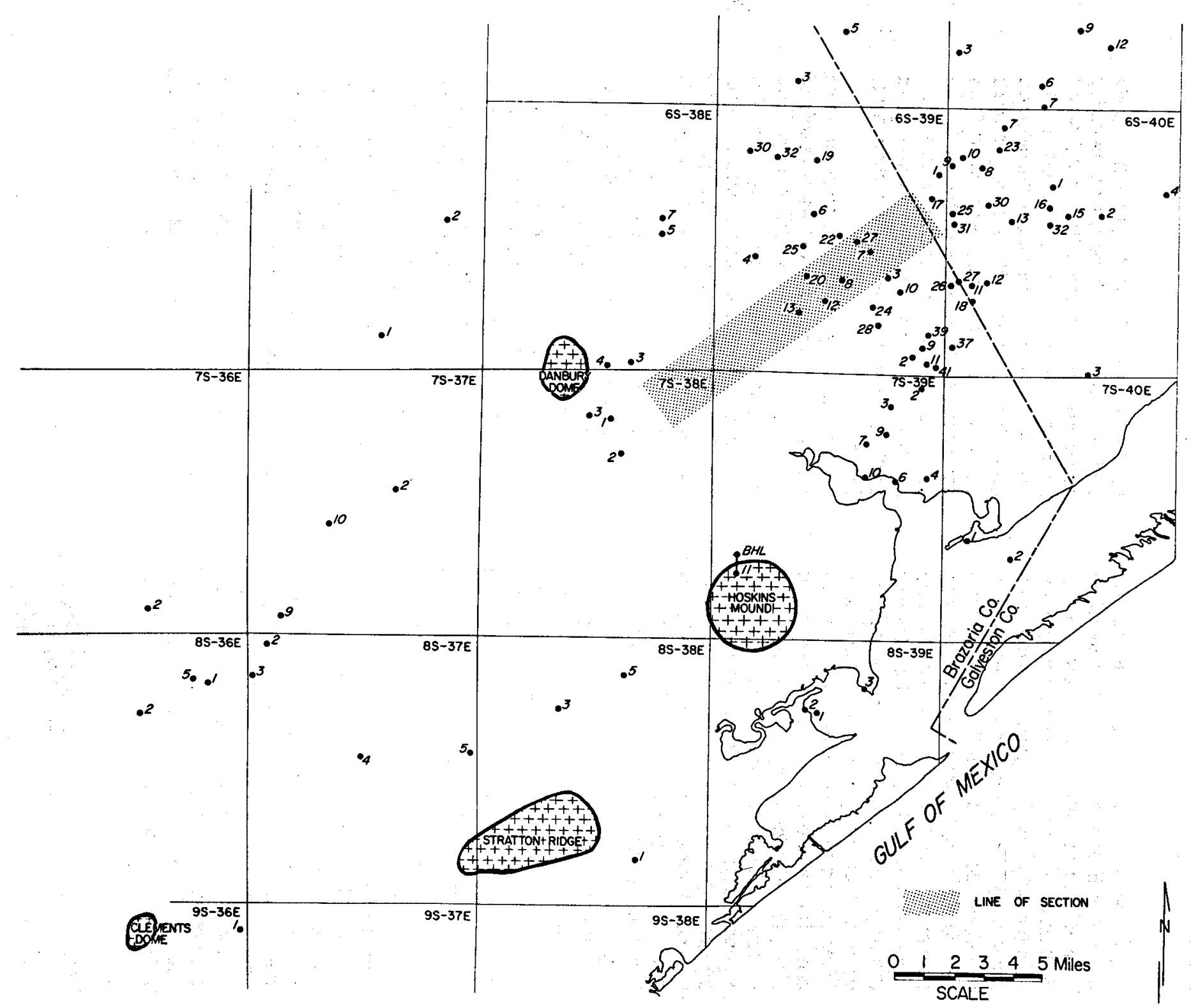

Figure 49. Location of wells which penetrate deeper than the is horizon, Austin Bayou Prospect. Location of the seismic line (fig. 50) is indicated by the dot pattern. 
SOUTHWEST

\section{TOP ANAHUAC \\ SHALE}

APPROXIMATE TOP OF FRIO

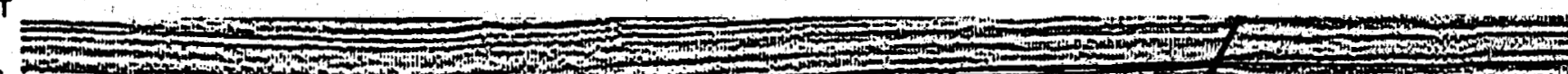

\section{5}

\section{T2}

\section{$T 4$}

5

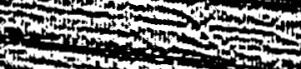

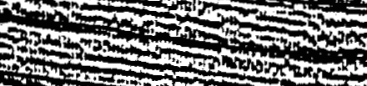

-

$\sin$

$x=0,10$

sinte

\section{$-20-205$}

$=\ln _{2}$

Figure 50. Seismic line across the Austin Bayou Prospect (courtesy of Teledyne Exploration Company).

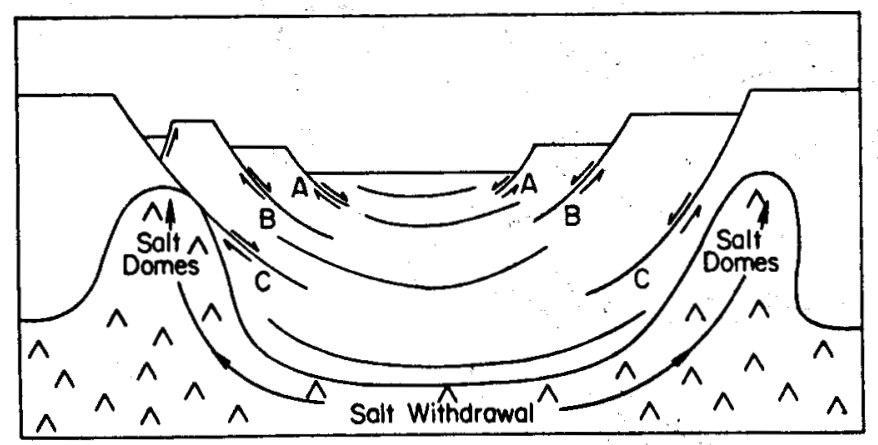

Figure 51. Collapse faults along margins of a salt-withdrawal basin as interpreted by Seglund (1974). 


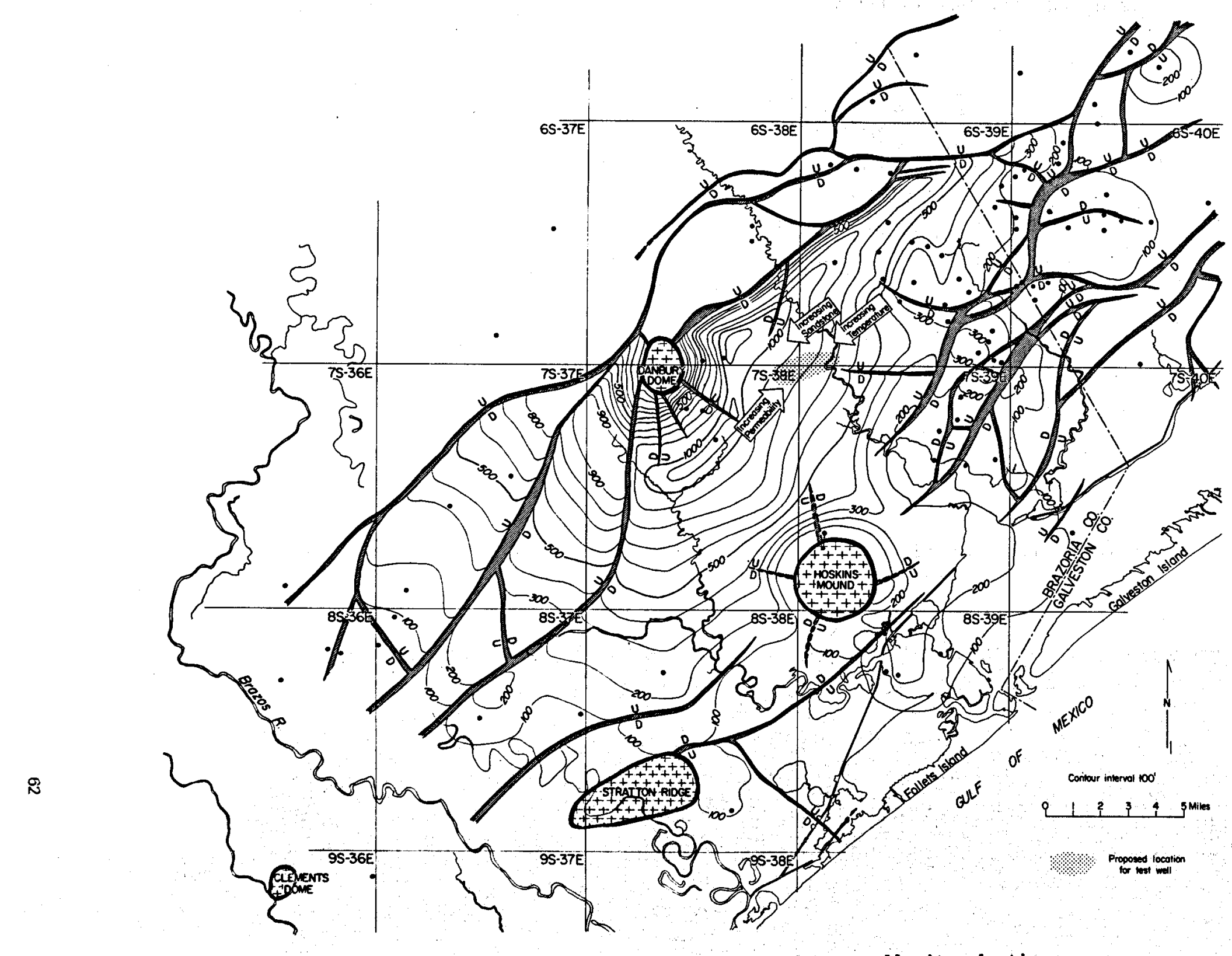

Figure 52. Sandstone percentage and location of test well site, Austin Bayou Prospect, Brazoria County, Texas. 


\section{Vertical Distribution of Depositional Sequences Within A Single Depositional Episode}

The prospective section within the Austin Bayou area is composed of seven progradational depositional sequences, several of which are characterized by low-porosity prodelta and distal delta-front shale and sandstone at the base, and by porous distributary-mouth bar and delta-plain sandstone and shale at the top.

The T5-T6 unit in the Austin Bayou Prospect is composed of a number of depositional sequences (shale-sandstone cycles) similar to those described by Fisher (1969). Ideally, these depositional sequences consist of prodelta shale at the base, delta-front shale and sand in the middle, and delta-plain sandstone and shale at the top (fig. 53). Several depositional sequences were deposited during a single depositional episode. Normally, depositional sequences (fig. 54) are incomplete, and several of the units of the ideal model may be lacking. A general increase in the amount of sandstone, accompanied by an increase in the porosity of the sandstones within individual depositional events, occurs upward in the cycle. This increase in the amount of sandstone and in its porosity is well demonstrated on the stratigraphic cross sections (figs. 55 to 58 ).

The base of each depositional sequence is represented by a thin shale unit with an extremely low resistivity (fig. 57, Phillips No. 1 Houston Farms "U," 12,680 to 12,700 feet). Low resistivity reflects shale purity and low content of silt-sized material. This basal shale is interpreted as representing the transgressive phase of the cycle (Galloway, personal communication). Just above the basal transgressive shale is a thick section of higher resistivity shale containing rare, very thin, intercalated siltstone beds. This shale is interpreted as prodelta in origin. Overlying the prodelta deposits is the delta-front section characterized by upward-increasing amounts of sandstone and corresponding coarsening of the sand grain size.

The base of the T5-T6 progradational cycle consists of distal delta-front deposits characterized by thin, fine-grained sandstones interbedded with thick shale (fig. 57. Phillips No. 1 Houston Farms "JJ," 15,290 to
15,910 feet). Distal delta-front deposits grade upward into very-fine- to fine-grained sandstones of the delta-front slope intercalated with thin shale units. Most of the thick sandstone-shale section from 15,020 to 17,335 feet in the Humble No. 1 Skrabanek is interpreted as having been deposited on a deltafront slope (fig. 56). The depositional event was culminated by deposition of thick, fine- to medium-grained sandstones of the distributary-mouth bars (fig. 58, Texas Co. and Ft. Bend No. 2 Houston Farms, 13,820 to 13,930 feet): These distributary-mouth bar sands are the most coarse grained, porous, and thick of the delta-front facies and constitute the most favorable reservoirs in the Austin Bayou Prospect area. Thicker sandstone bodies also occur laterally to this delta-front sequence where sands were reworked by marine processes into bars and spits; these reworked sands accumulated on the marginal part of the delta front. Thick, blocky sandstones, particularly of the " $A$, " "B," and " $C$ " sequences, represent relict distributary channel-fill deposits on the Frio delta plain; interbedded shale was deposited in interdistributary areas.

Deltaic sedimentation dominated Frio (T5-T6) deposition in the Austin Bayou Prospect area. Sandstones of the lower sequences were deposited on the distal delta-front slope and the delta-front slope. Uppermost sandstone facies were deposited as distributary-mouth bars and in distributary channels on the Frio delta plain. This vertical progradational sequence pattern resulted from early, rapid subsidence of the saltwithdrawal basin, followed by later stability, during which time delta-plain sediments accumulated. Younger, deeper-water prodelta strata overlie the T5 marker. 


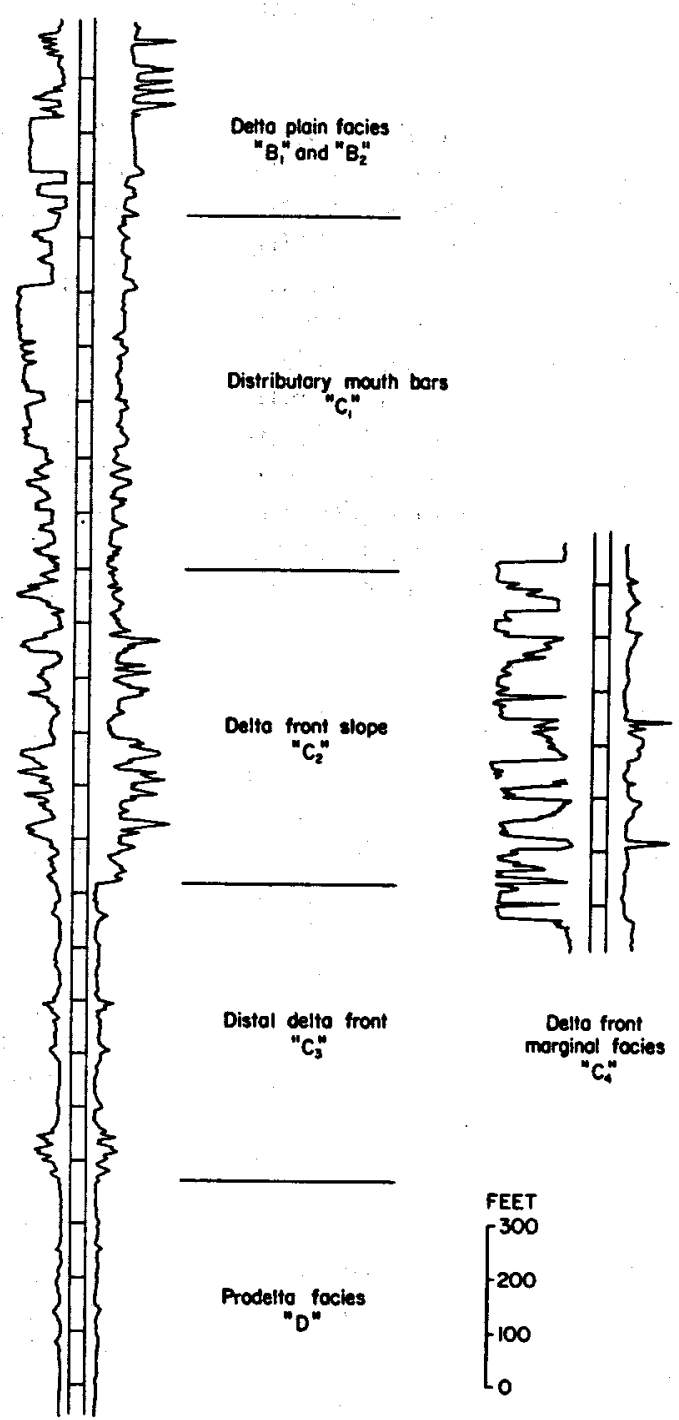

Figure 53. Depositional environments of a high-constructive lobate delta system interpreted from electrical log patterns (after Fisher, 1969). 
PHILLIPS

No.1 Houston "JJ"

BRAZORIA COUNTY

$65-39 E-7$

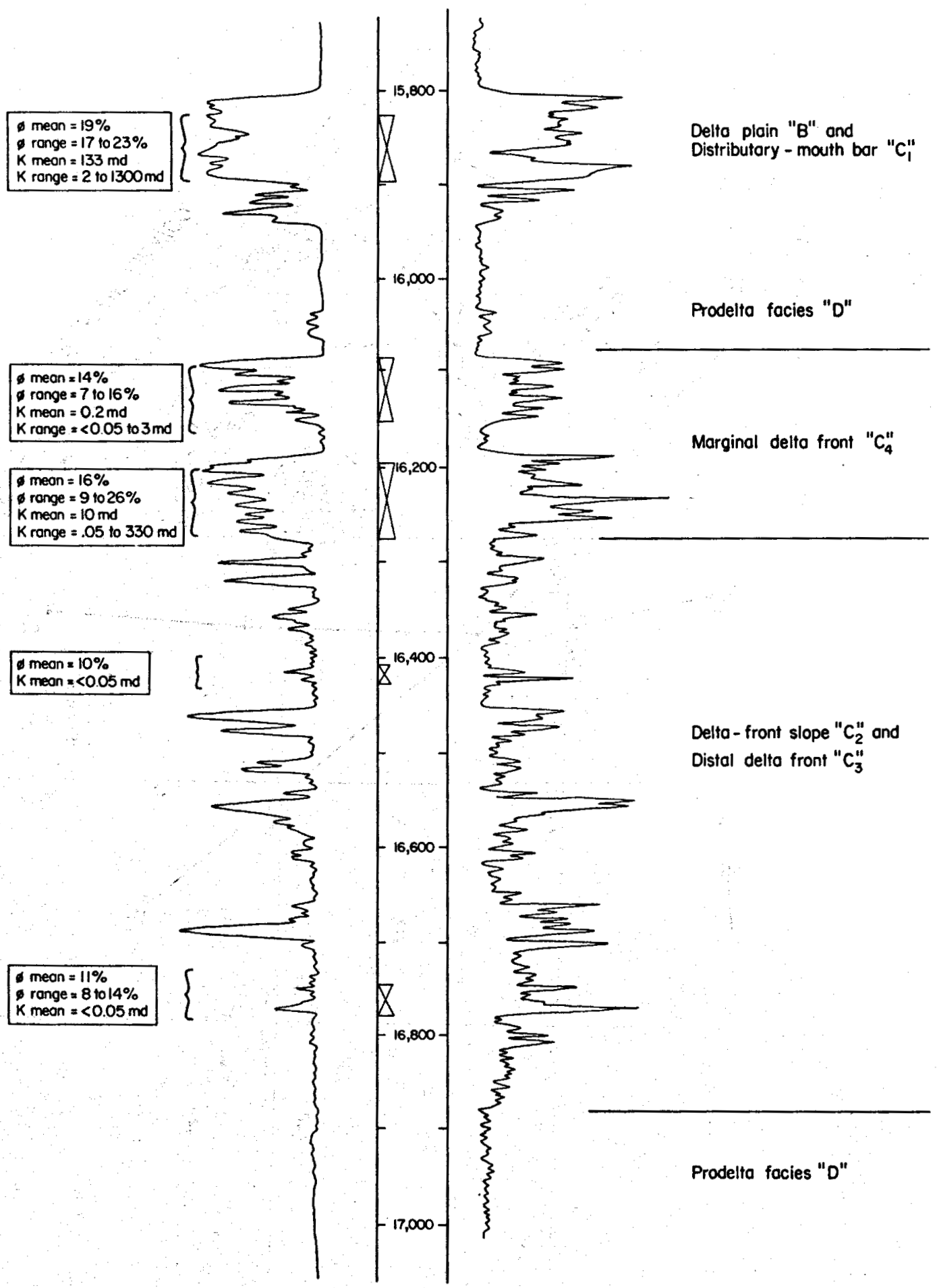

Figure 54. Depositional environments of high-constructive lobate delta systems interpreted from electrical log of the Phillips No. 1 Houston "JJ." Highest porosity and permeability occur at top of deltaic cycles in distributary channel-fill and distributary-mouth bar deposits. 


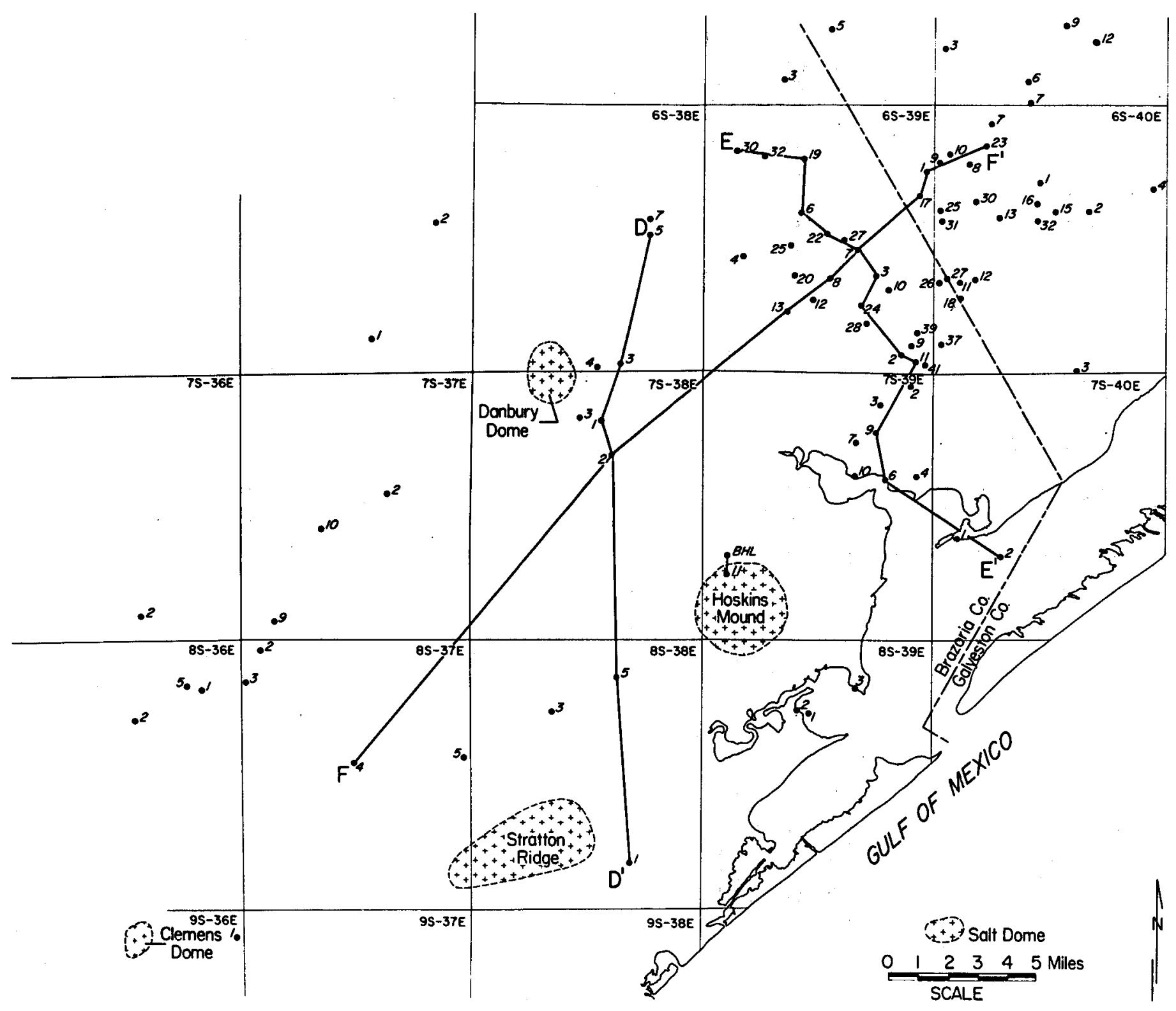

Figure 55. Location of wells which penetrate deeper than T5 horizon, Austin Bayou Prospect, and locations of stratigraphic sections $D D^{\prime}, E^{\prime}$, and $F F^{\prime}$. 


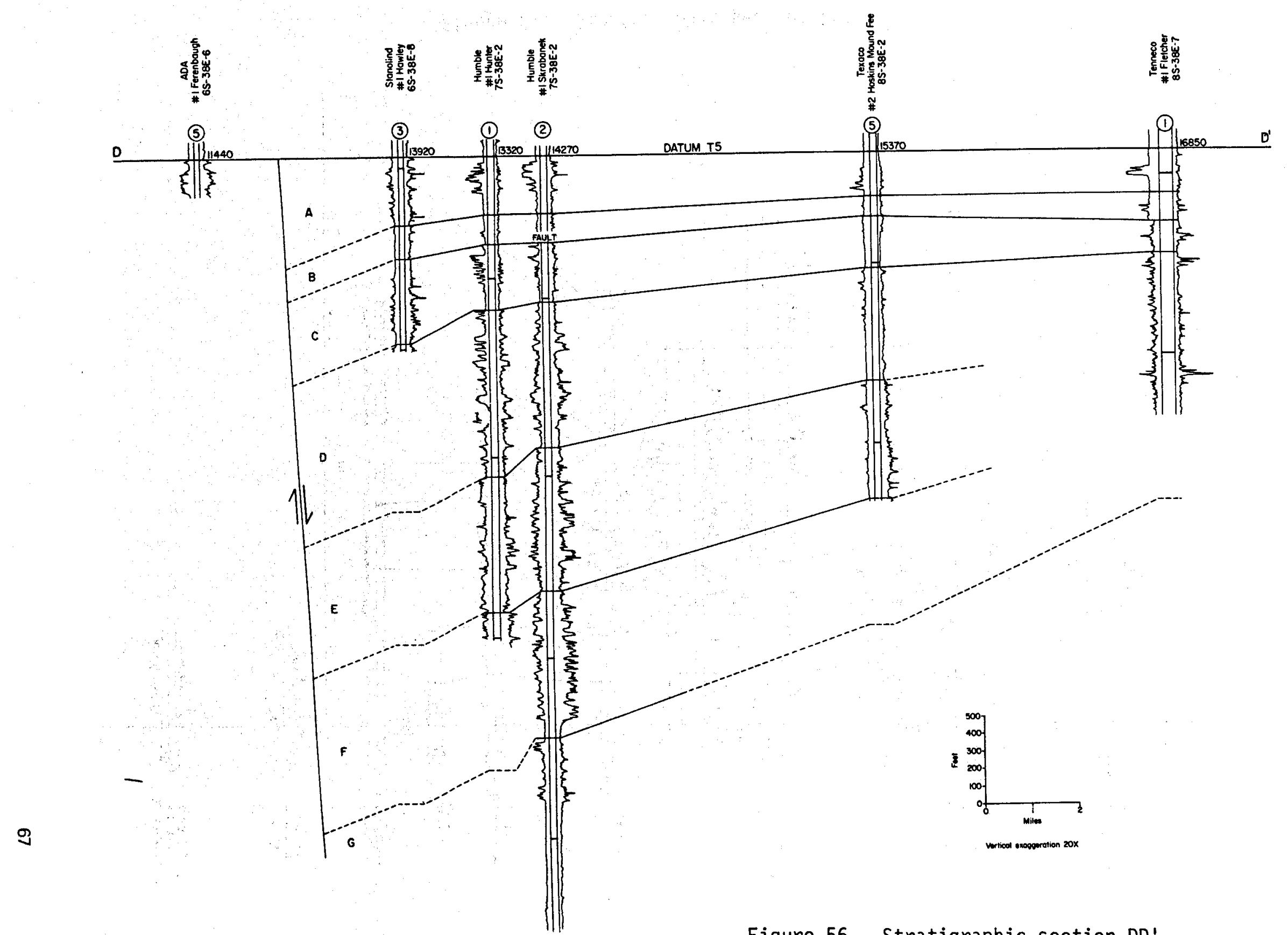

Figure 56. Stratigraphic section DD'. 


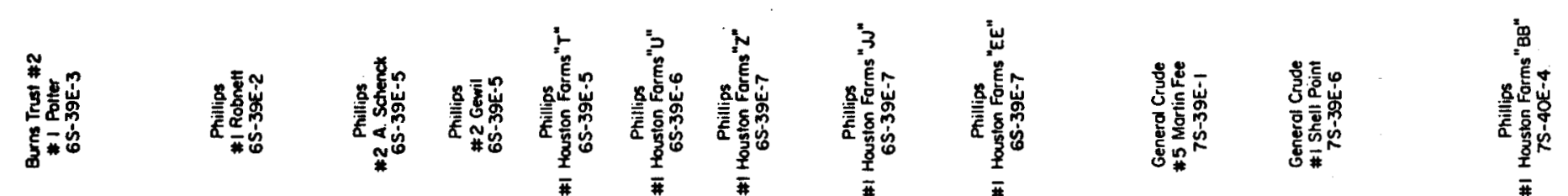

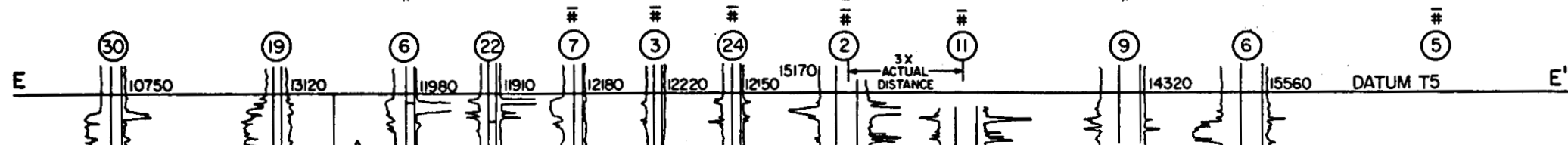
,

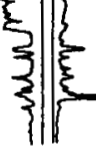

Figure 57. Stratigraphic section EE'. 


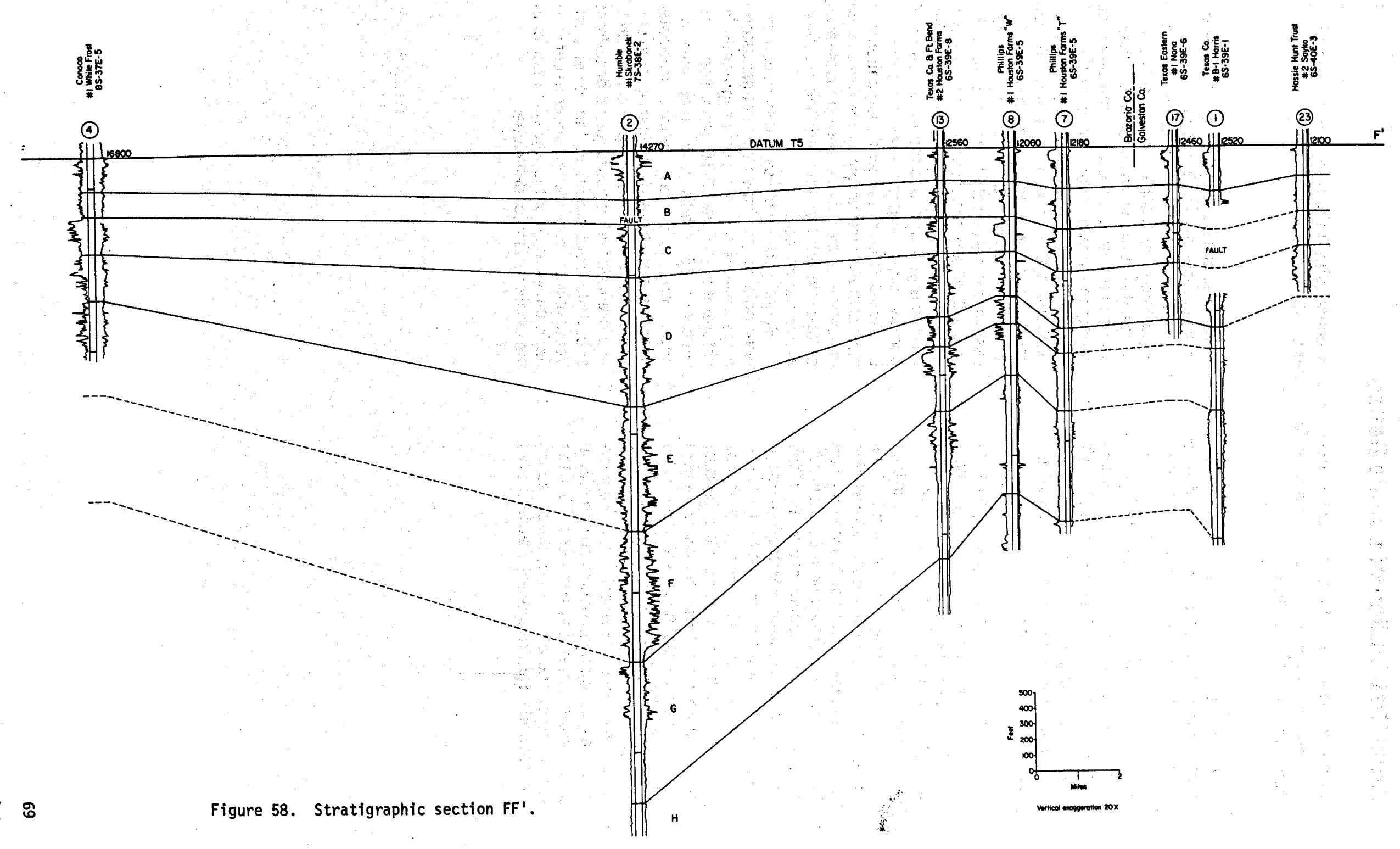




\section{Areal Distribution of Lobate Deltas}

Paleo net-sandstone maps of each depositional sequence within the reservoir section of the Austin Bayou Prospect indicate that these sands were deposited as highconstructive lobate deltas.

Paleo net-sandstone maps (figs. 59 to 62) illustrate the interpreted distribution of sand prior to penetration of the Frio by salt structures and cutting by growth faults. These paleo net-sandstone maps, therefore, show original sand volume. A model by Fisher (1969) of a high-constructive delta (fig. 63) best represents the distribution of sandstone and shale within the T5-T6 interval of the Austin Bayou Prospect.

The paleo net-sandstone map of sequences $D-F$ (fig. 59) outlines a large lobate delta 24 miles wide (strike direction) and at least 30 miles long (dip direction). The sandstone bodies downdip of the growth fault system represent only the Gulfward or distal half of the entire lobate delta. Correlation across the large number of growth faults on the northwest side of the map area is difficult; therefore, the configuration of the sandstone units which are equivalent to those mapped here are not shown northwest of the faults. The main axis of sediment transport was across this fault zone very near the Danbury dome. More than 1,000 feet of sediment accumulated locally near the dome. This section is well illustrated in the D-F sequences of the Humble No. 1 Skrabanek and No. 1 Hunter wells (fig. 64) where sands are interpreted as having been deposited primarily in delta-front slope environments. To the northeast, on the other hand, deltaic sands were reworked and redeposited as delta-front marginal sand bodies in the more stable area of the Chocolate Bayou structure.

The paleo net-sandstone maps of the upper three depositional sequences $\mathrm{C}, \mathrm{B}$, and $A$ (figs. 60 to 62 ) show a considerably thinner section and more elongate shape of the sandstone bodies than those of the D-F sequences. Three depocenters occur in sequences $C$ and $B$ : one which extends across Danbury dome as in the previous D-F sequences; a second which occurs northeastward in the area of Chocolate Bayou field, and a third which occurs between the two areas. In sequence $A$, the three delta lobes have merged into a continuous band of narrow, dip-elongated sandstone bodies. Blocky spontaneous potential log patterns of most of the sandstone units of the A sequence indicate that the sands were deposited as delta-plain, channel-fill, and distributarymouth bar deposits.

Superimposing the sand distribution patterns obtained from the paleo net-sandstone maps reveals the obvious progradational nature of the entire T5-T6 depositional episode (fig. 65). Wells in the map area will encounter proximal deltaic deposits (marginal delta front, distributary-mouth bar, and delta plain) in the upper part and prodelta and distal deltaic deposits (distal delta-front and delta-front slope) in the lower part. Variations are expected to occur depending upon the location of the well with respect to the location of major delta lobes. 


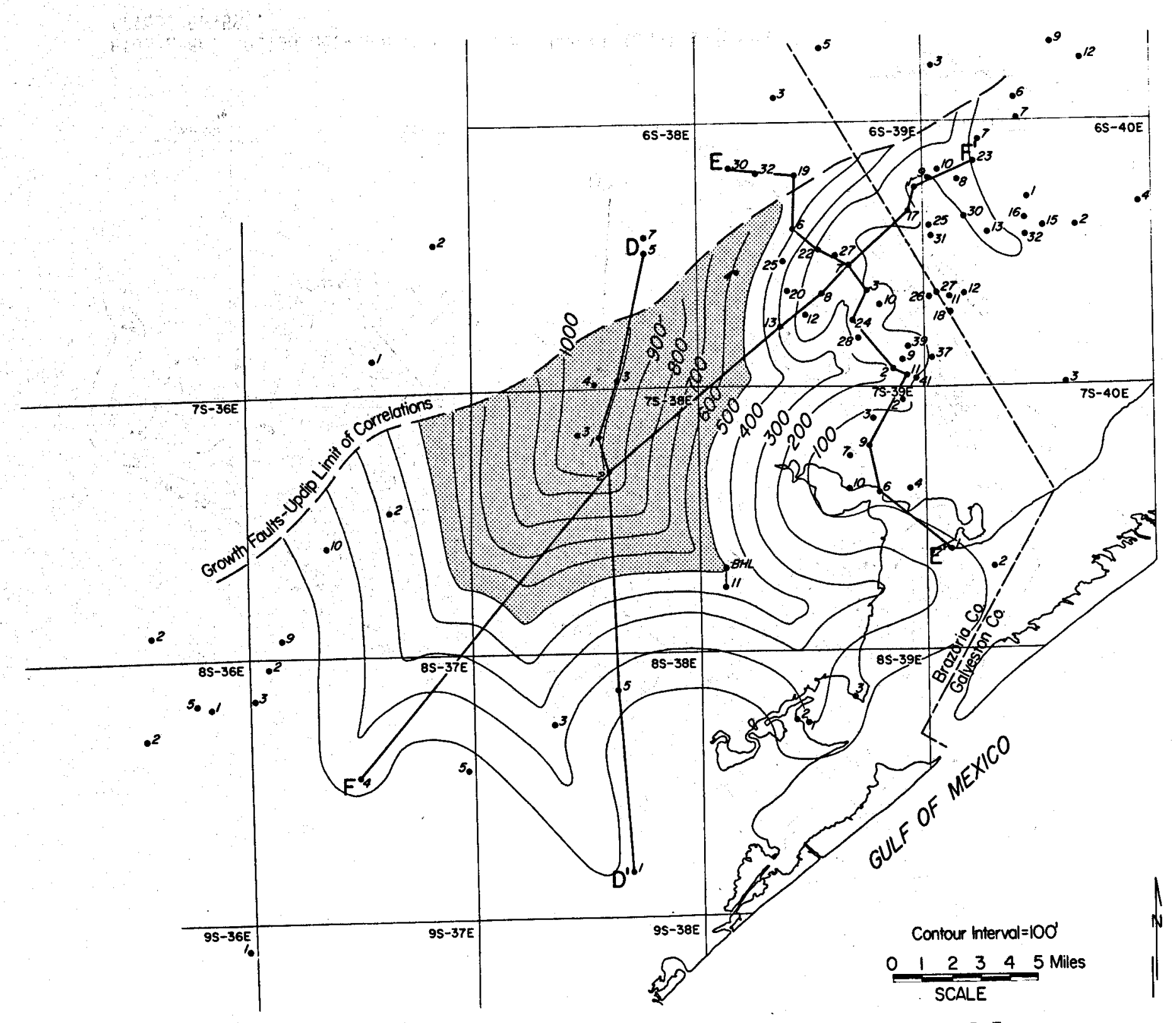

Figure 59. Paleo net-sandstone map of depositional sequences $D-F$ (figs. 56-58). 


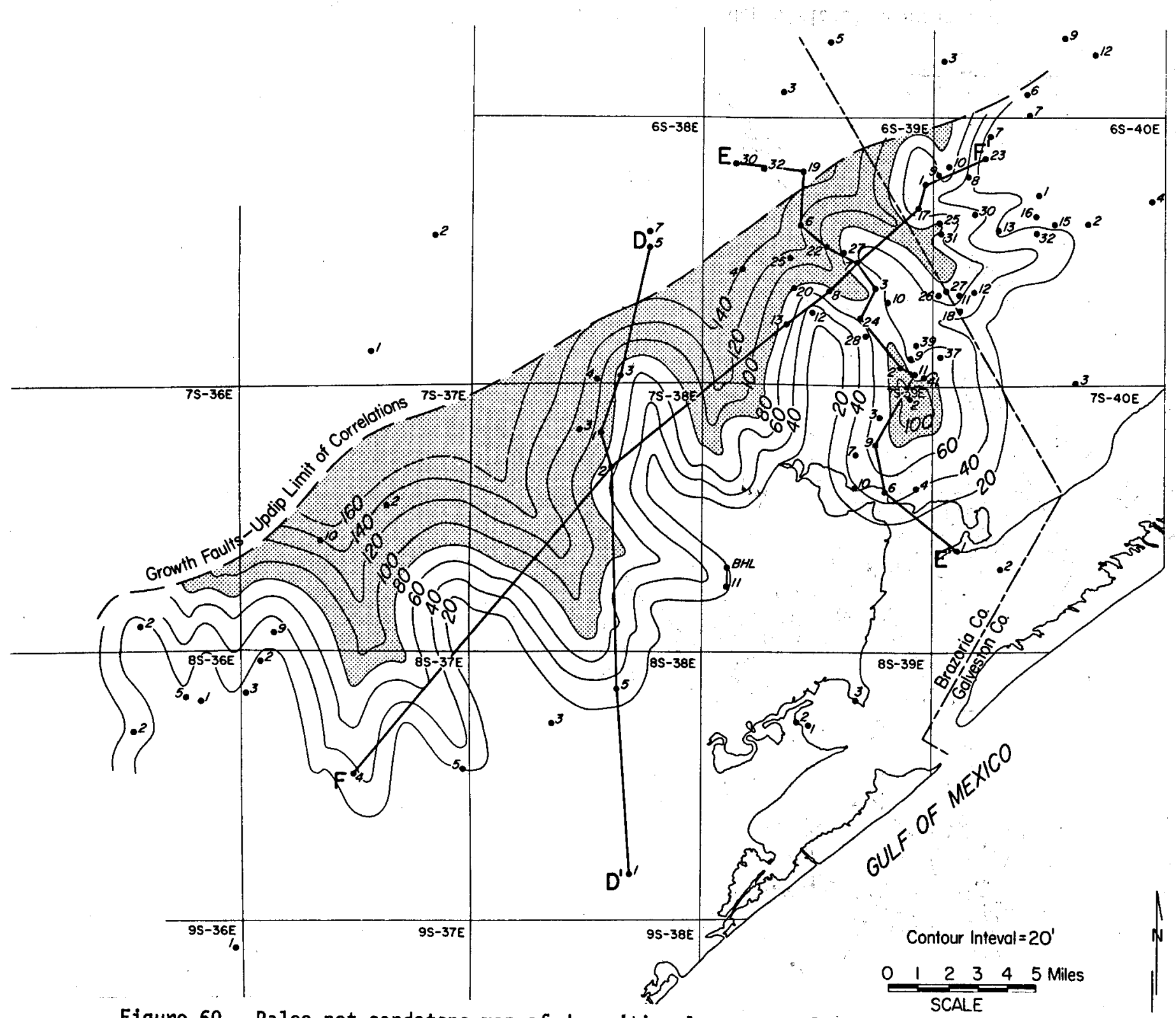

Figure 60. Paleo net-sandstone map of depositional sequence $C$

(figs. 56-58). 


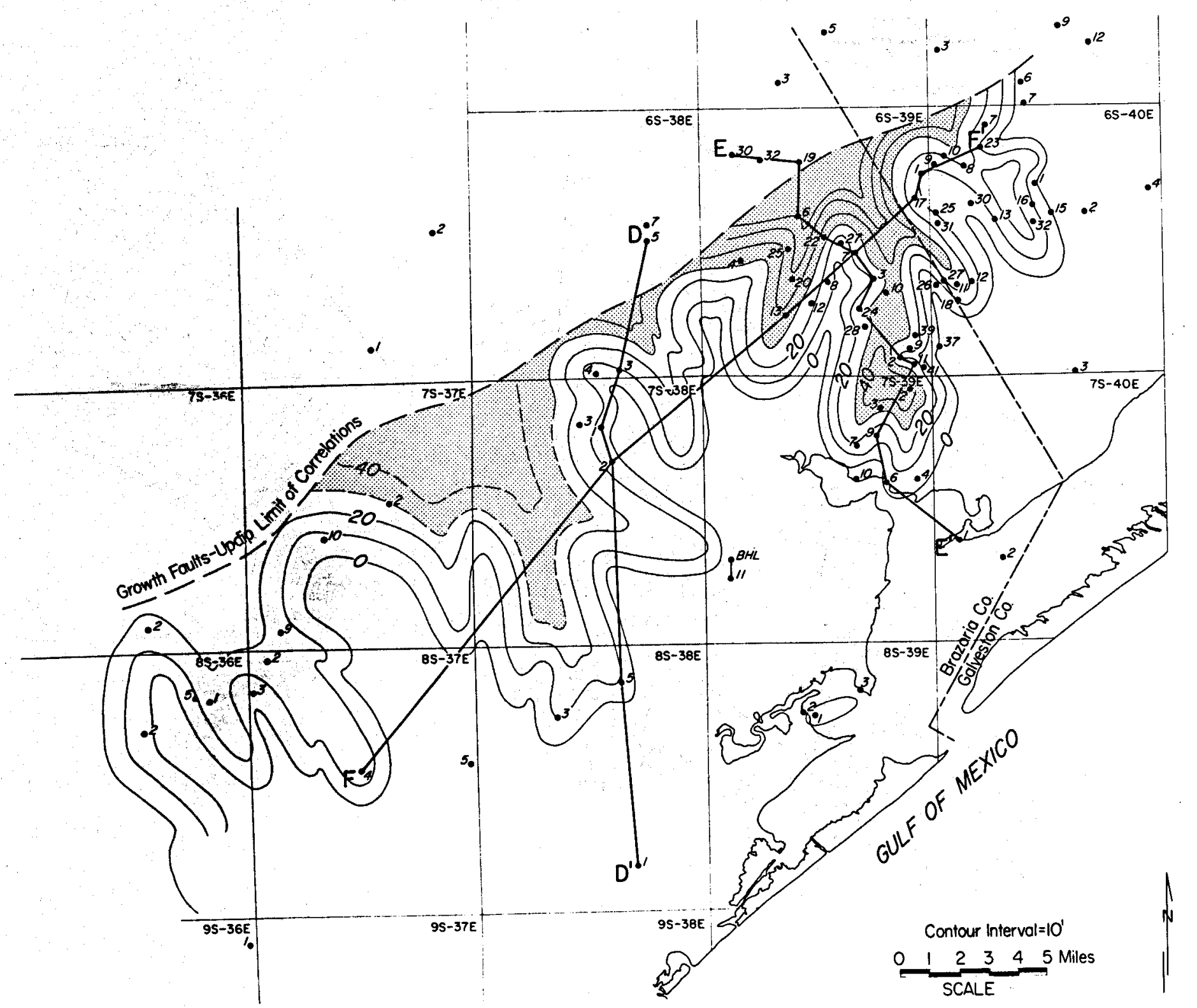

Figure 61. Paleo net-sandstone map of depositional sequence $B$ (figs. 56-58). 


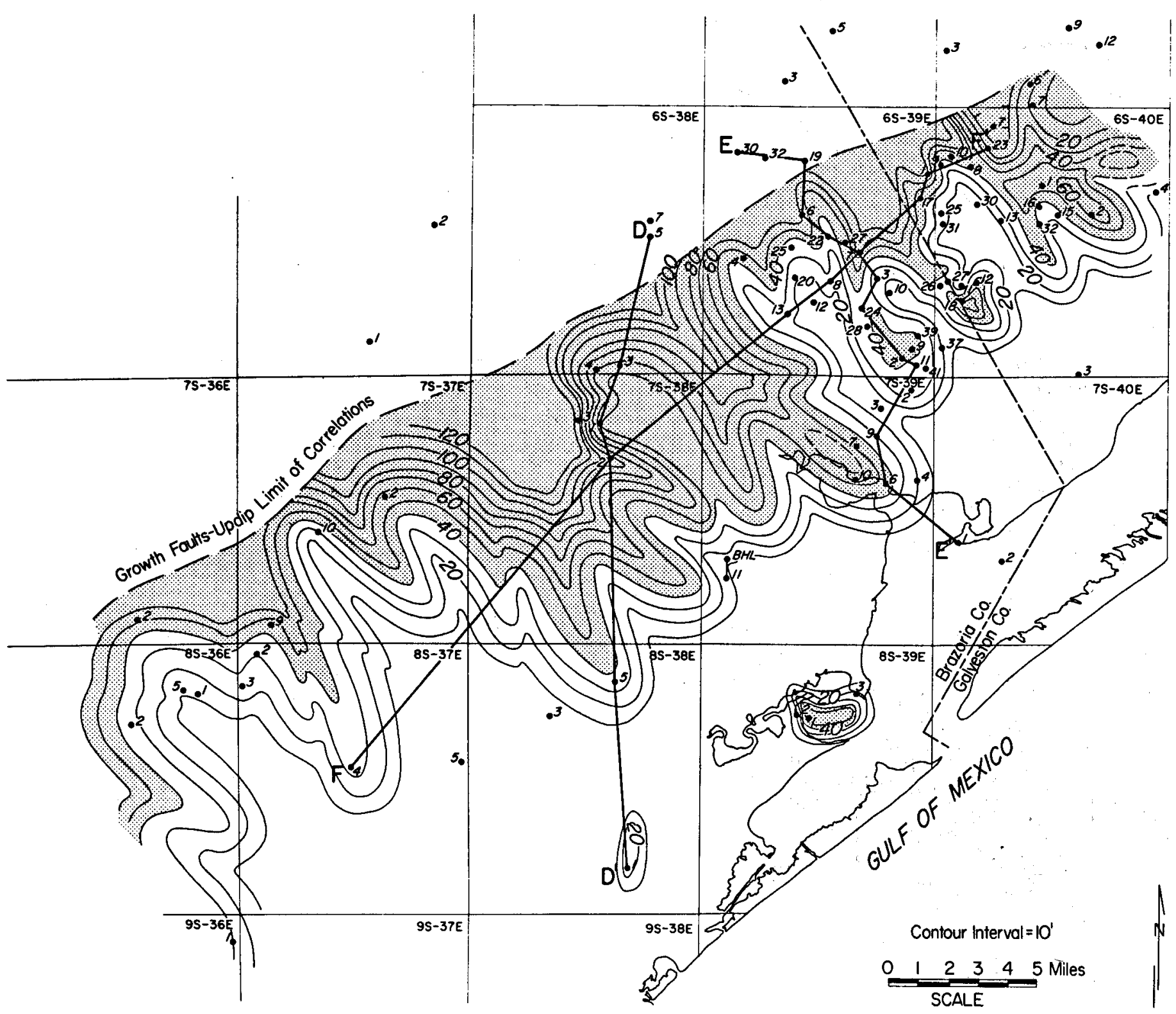

Figure 62. Paleo net-sandstone map of depositional sequence $A$ (figs. 56-58). 


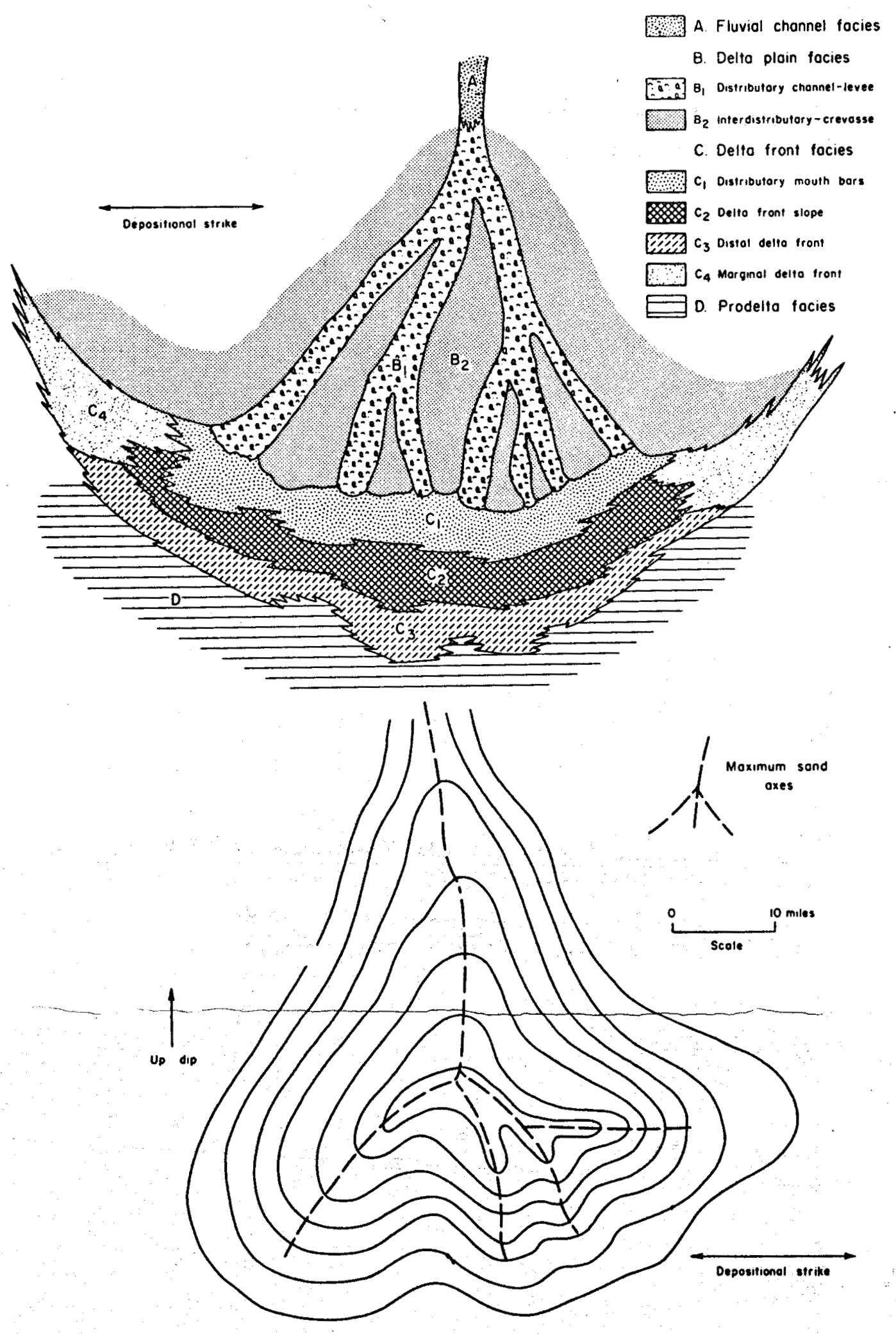

Figure 63. Principal depositional environments and sand patterns, highconstructive lobate delta systems, Gulf Coast basin (Fisher, 1969). 


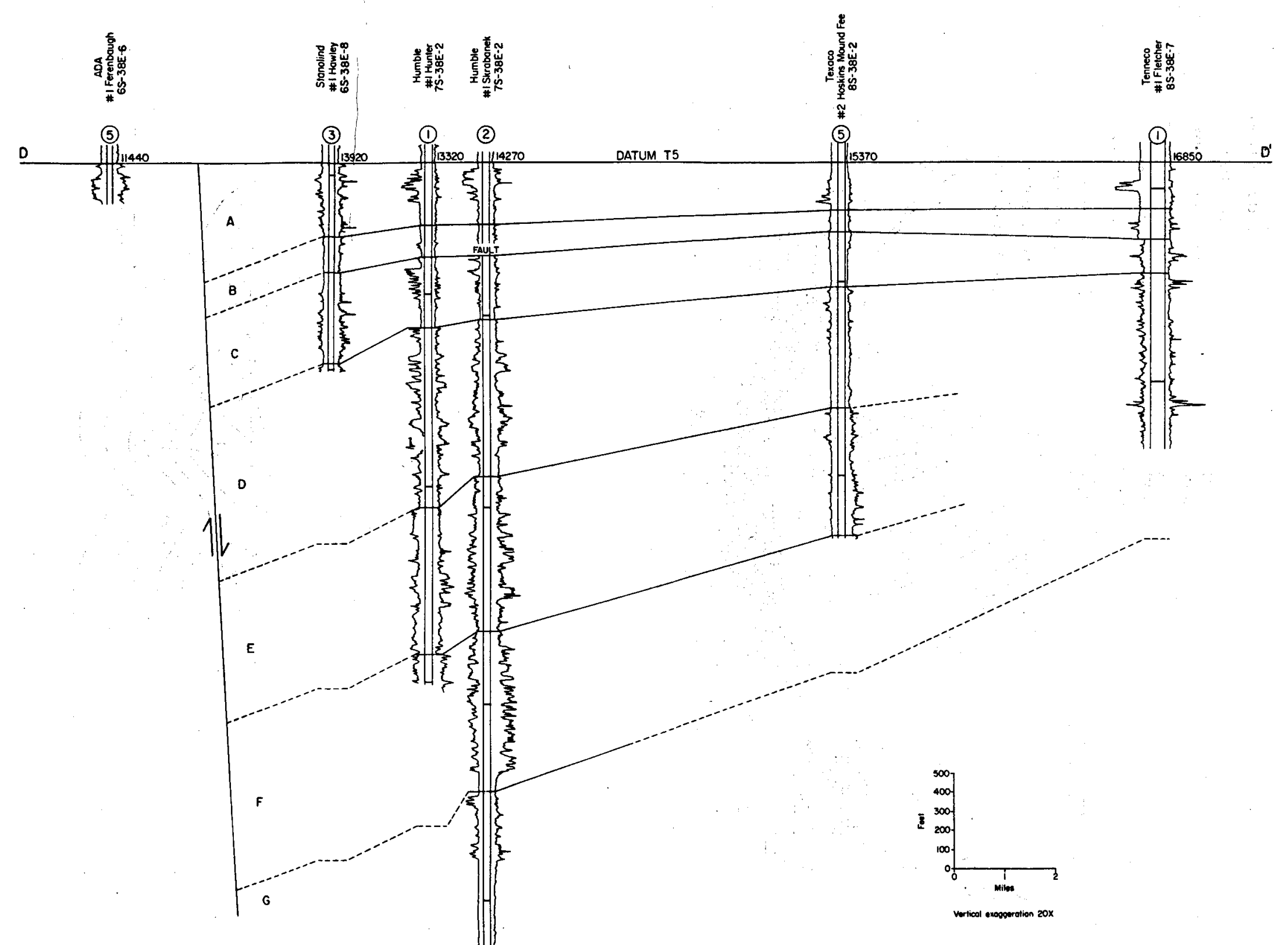

Figure 64. Stratigraphic section DD'. 
C

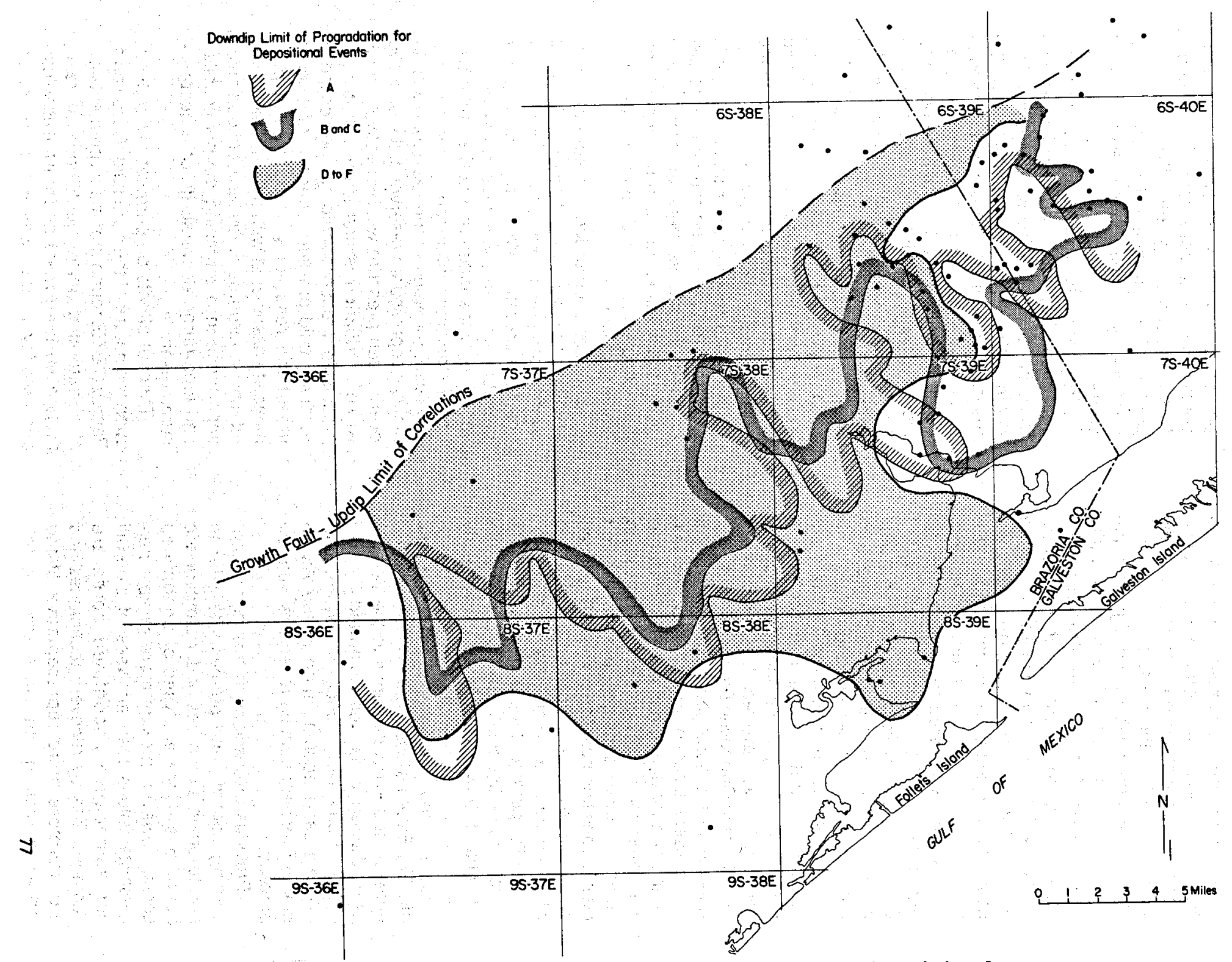

Figure 65. Composite map, progradational limits of depositional sequences $D-F, C$, and $A$ (figs. 59,60 and 62 ). 


\section{Porosity and Permeability-Core Analysis}

Porosity and permeability vary considerably both vertically and laterally within each depositional sequence in the Austin Bayou Prospect.

Porosity and permeability in the Austin Bayou Prospect vary both vertically within each depositional sequence and also laterally from one part of the Prospect to another. Porosity and permeability are highest in the Chocolate Bayou field, where porosity ranges from 2 to 27 percent, and permeability, up to thousands of millidarcys. Vertically, the best reservoir sandstones are at the top of deltaic progradational sequences-distributary-mouth bar and distributary channel-fill sandstones (fig. 66) - and the worst are in the delta-front slope and distal delta-front deposits. Southwest of Chocolate Bayou field, porosity and permeability from sidewall cores decrease to between 9 and 34 percent and to less than 100 millidarcys, respectively. In this area, sandstone units in the Humble No. 1 Skrabanek are tightly cemented with quartz and calcite and have less leached porosity than those in Chocolate Bayou field (fig. 67). Analysis of the sonic log indicates that the entire reservoir section in the Skrabanek well, near Danbury dome, has porosity similar to that determined from both sidewall cores and cuttings. Rapid subsidence accompanied rapid deposition near the dome and resulted in limited early cementation and later leaching while the sands were still shallow and, subsequently, permitted more compaction with burial. In the Chocolate Bayou area, on the other hand, slower subsidence allowed early cementation which, in turn, prevented significant compaction during subsequent burial (fig. 67). Extreme loss of porosity with burial of uncemented Pliocene sands in the Ventura field, California, is well illustrated by $\mathrm{Hsu}$ (1977). Hsu's work suggests that areas of thickest sand accumulation in the Austin Bayou Prospect contain reservoirs with low porosity.

Previous discussions in this report concerning porosity and permeability refer to measurements on cores under atmospheric conditions. Core analyses of unconfined cores, however, provide more reliable permeability values than analyses of sidewall cores, because unconfined cores are damaged less by recovery techniques and are therefore more representative of the formation rock in situ. An example is the porosity-permeability relationships for both cores and sidewall cores for a well located in Nueces County (fig. 68). Porosities and permeabilities of sidewall cores are substantially higher than those determined for cores.

Permeability data from unconfined specimens may be satisfactory for predicting the deliverability of shallow reservoirs. As the depth of the reservoir increases, and as the reservoir pressure declines, the reduction of permeability caused by the effective overburden pressure and temperature becomes increasingly significant. Consequently, permeability from core analysis data can be expected to overestimate the deliverability of deep geopressured geothermal reservoirs.

Alterations of permeability, porosity, and elastic properties caused by pressure and heat can have a substantial influence on the bulk volume, pore fluid volume, and deliverability of a reservior. For this reason, it is important to understand the causes of discrepancies that exist between porosity and permeability values measured on unconfined cores and those measured on in situ sandstone reservoirs.

Effective overburden pressure of a reservoir is the difference between the total overburden pressure and the internal reservoir fluid pressure. When both overburden pressure and reservoir fluid pressure are varied, only the difference between the two has a significant influence on the dynamic physical properties of the reservoir rock. In highly geopressured reservoirs, the effective overburden pressure will be relatively small when production is first started, but it increases in direct proportion to the decline in reservoir fluid pressure over the producing life of the reservoirs. Reduction in permeability associated with an increase in the effective overburden pressure is of particular importance in determining the permeability and long-range deliverability of a geopressured reservoir.

Thermal effects on permeability depend upon the nature of the pore fluid. Casse and Ramey (1976) found that the oil permeability of oil-saturated Berea sandstone was relatively insensitive to heat, and that the absolute permeability to gas was independent of 
temperature. In water-saturated Berea sandstone, however, aqueous permeability was very sensitive to temperature because of the combined influence of thermal expansion of grains into pores and pore throats, mechanical stresses caused by differential expansion of different minerals along different crystallographic axes, and fluid-rock surface interactions. Determination of absolute permeability to water can be seriously affected by the swelling of certain types of clay particles, such as montmorillonite. However, increasing the salinity of water tends to reduce the swelling potential of the clays. The deactivation of the swelling potential of clays by heat (Grim, 1962) is an interesting phenomenon which might be detectable in deep reservoirs that have been exposed to high temperatures. In a flowing water well, clay particles can be dislodged from the rock, obstruct or plug flow channels, and reduce permeability. Gas released from solution in a pressurereduced reservoir will decrease the effective permeability to water in the same manner.

Empirical relationships show that permeability normally increases as porosity increases. The type of porosity has an influence on permeability; for example, isolated pore spaces (vugs) which are not interconnected with flow channels, microcracks in cement, pores within kaolinite clay, and pore fillings do not contribute to effective permeability.

Permeability values for unconfined cores from geopressured formations penetrated by a well in Brazoria County range from less than 0.1 millidarcy for cores with low porosities of less than 15 percent to several hundred millidarcys in the porosity range from 20 to 30 percent (fig. 69). In the No. 1 Houston "JJ" well (fig. 69) initial effective overburden pressure was $3,870 \mathrm{psi}$ at a depth of 15,244 feet (just above the cored interval). The value of the effective overburden pressure is based on a bottom-hole pressure of 11,375 psi recorded in 1965 (fig. 70); a bottom-hole temperature of $321^{\circ} \mathrm{F}$ was recorded at the same time. One year later (in 1966) a bottom-hole pressure of 5,600 psi was measured at the same depth. Hence, during this 12-month period the reservoir pressure declined by 5,775 psi, and the effective overburden pressure increased from 3,870 to 9,644 psi. Although incomplete information is available on the effect of overburden pressure and temperature on gas and liquid permeabilities, Casse and Ramey
(1976) noted that absolute permeability to water in Berea sandstone (fig. 71) decreased by over 30 percent when subjected to a confining pressure of $4,000 \mathrm{psi}$ at a temperature of $300^{\circ} \mathrm{F}$. These pressure and temperature conditions are roughly the same as those previously described in the No. 1 Houston " $J \mathrm{~J}$ " well when production was started in 1965. The additional reduction in permeability, caused by pressure decline and resulting buildup of effective overburden pressure to 9,644 psi, cannot be determined from figure 71. However, extrapolation of the trend of the relationship shown in figure 71 indicates that total reduction in permeability will exceed 50 percent. Data from McLatchie, Hemstock, and Young (1958) show that rocks with low permeability are more sensitive to changes in effective overburden pressure than rocks with high permeability (fig. 72). Reductions in permeability approach 90 percent when low-permeability rocks are subjected to effective overburden pressures of 5,000 psi or more.

Even if a 50-percent reduction of coreanalysis permeabilities (fig. 69) is allowed to account for effective overburden pressures observed in deep geopressured reservoirs, the resultant permeabilities remain much higher than those obtained from production flow tests. For example, a comparison of original and late-time performance curves (fig. 73) for (1) a highly geopressured reservoir, the " $S$ " Sandstone in the Phillips No. 1 Houston "FF." and (2) a slightly geopressured reservoir, the upper Weiting sandstone in the Phillips No. 1 Rekdahl, indicates that a much greater reduction of permeability occurs in the reservoir that was originally highly geopressured. Curves for the No. 1 Houston "FF" show that the flow rate q decreased substantially at a constant value of the pressure drawdown parameter $\bar{P}^{2}-P^{2} w f / \mu z$ during production time interval between original and late flow tests. Similar curves for the Rekdahl well show that $q$ changed little but increased somewhat for a constant value of the pressure drawdown parameter. The angle between the original and late-time performance curves should provide a qualitative estimate of how much the $\mathrm{Kh}$ product diminished during the production time interval. Clearly, largest reduction in the $\mathrm{Kh}$ product occurred in the highly geopressured reservoir. Quantitative methods for calculating permeability from well-production tests are discussed in detail in the next section. 
PHILLIPS

No.I Houston "JJ"

BRAZORIA COUNTY

6S-39E-7

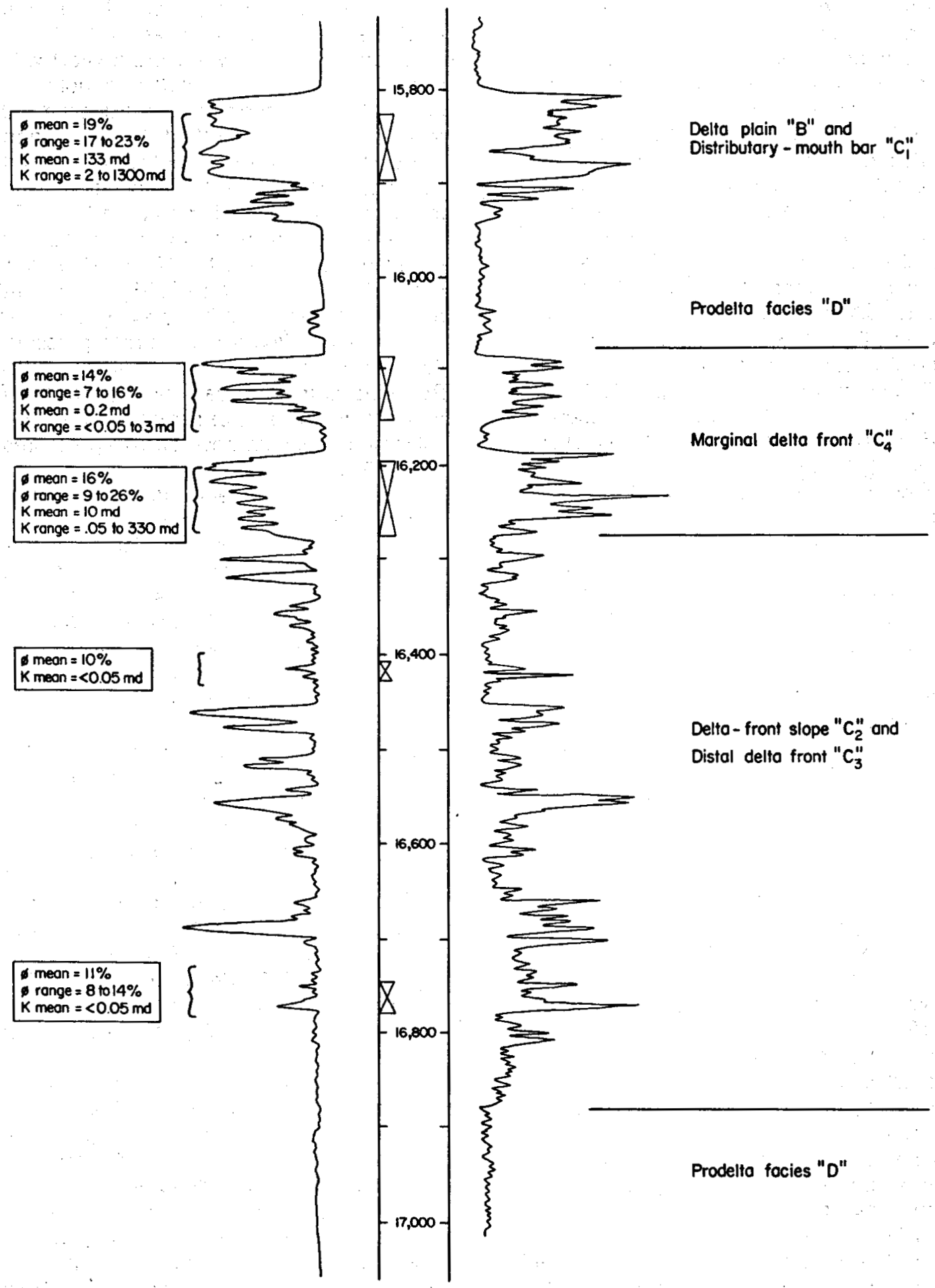

Figure 66. Depositional environments of high-constructive lobate delta systems interpreted from electrical log of Phillips No. 1 Houston "JJ." Highest porosity and permeability occur at top of deltaic cycles in distributary channel-fill and distributary-mouth bar deposits. 


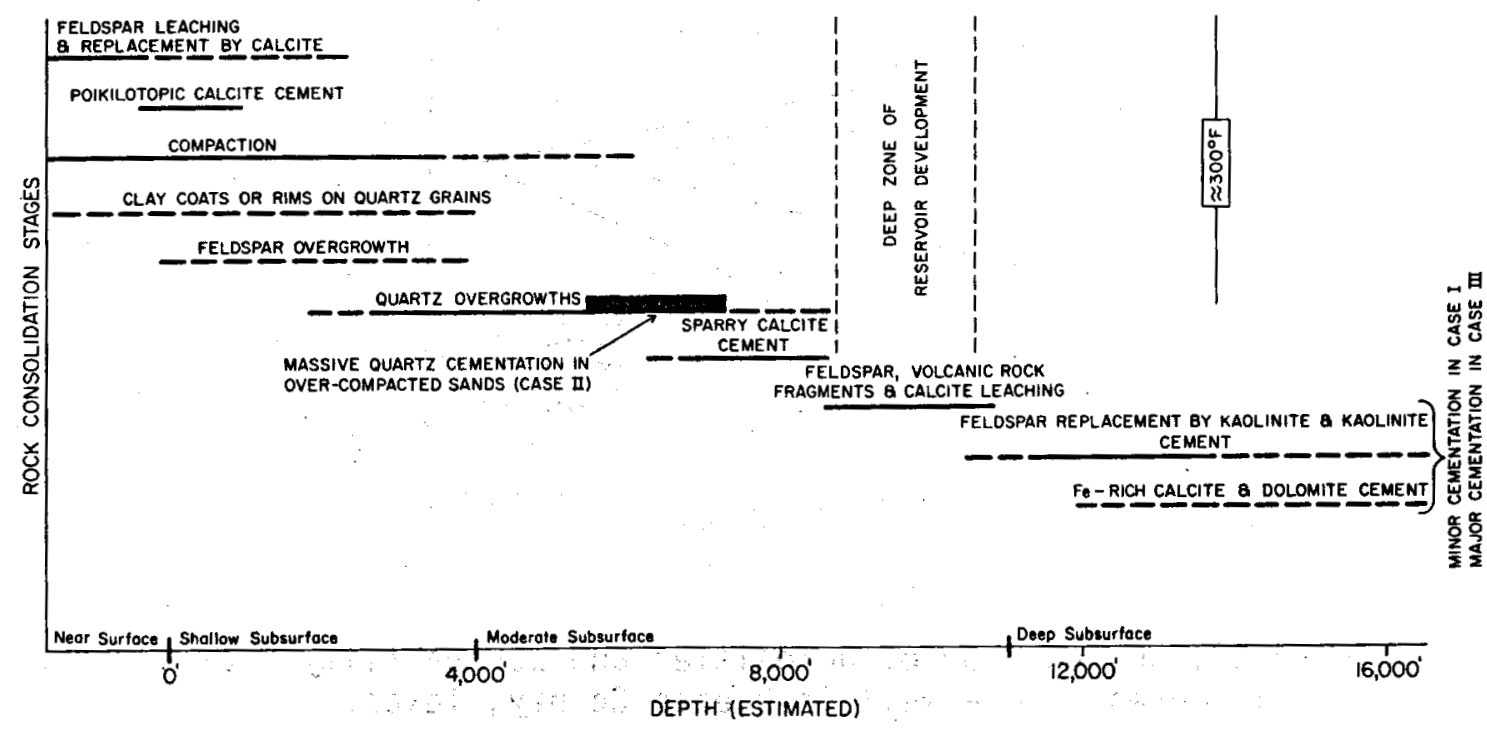

CASE I

UPPER TEXAS - CHOCOLATE BAYOU/ALTA LOMA FIELD AREA

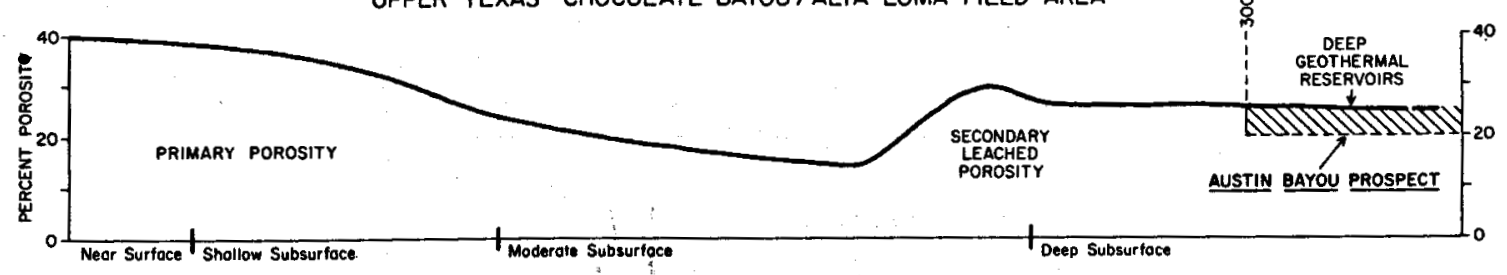

CASE II

UPPER TEXAS - DANBURY DOME AREA

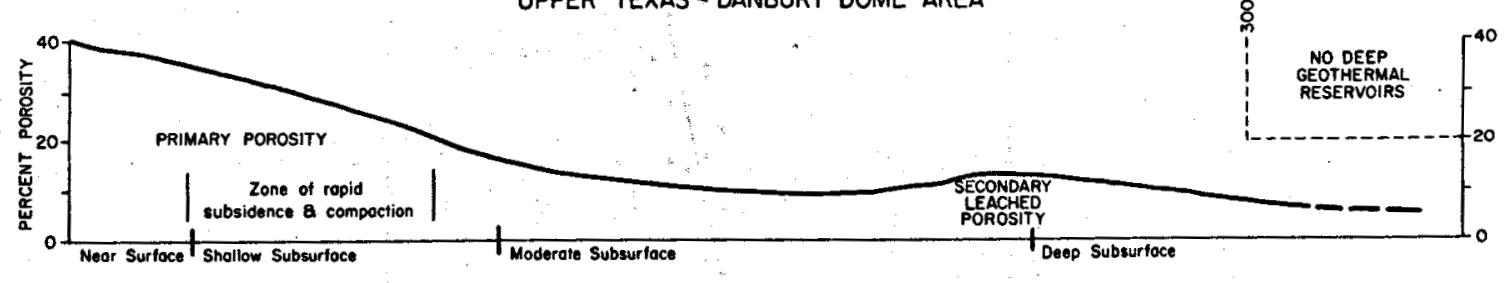

CASE III LOWER TEXAS (LINDQUIST, 1976)

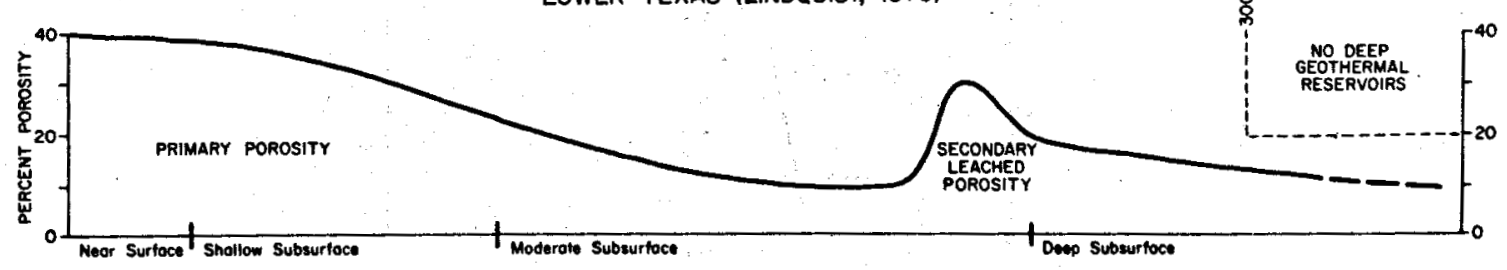

Figure 67. Rock consolidation stages with increasing depth of burial (upper) and case histories of consolidation in the Chocolate Bayou/Alta Loma field areas, Danbury dome area, and Lower Texas area (10wer). 


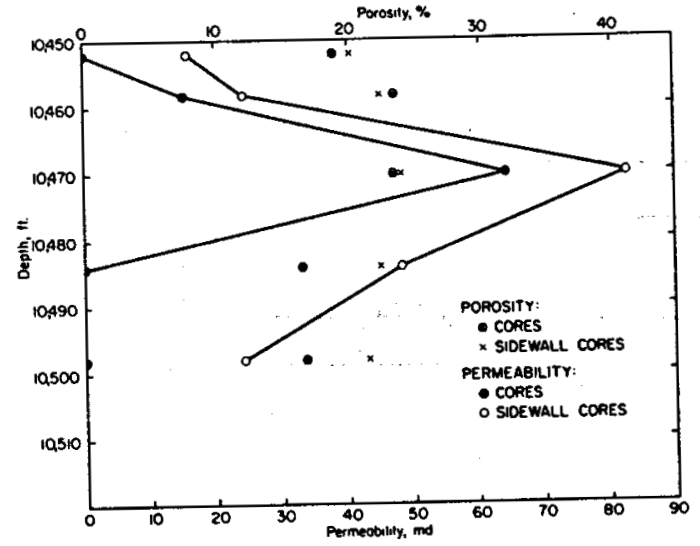

Figure 68. Comparison of porosities and permeability from cores and sidewa11 cores from a well in Nueces County, Texas.

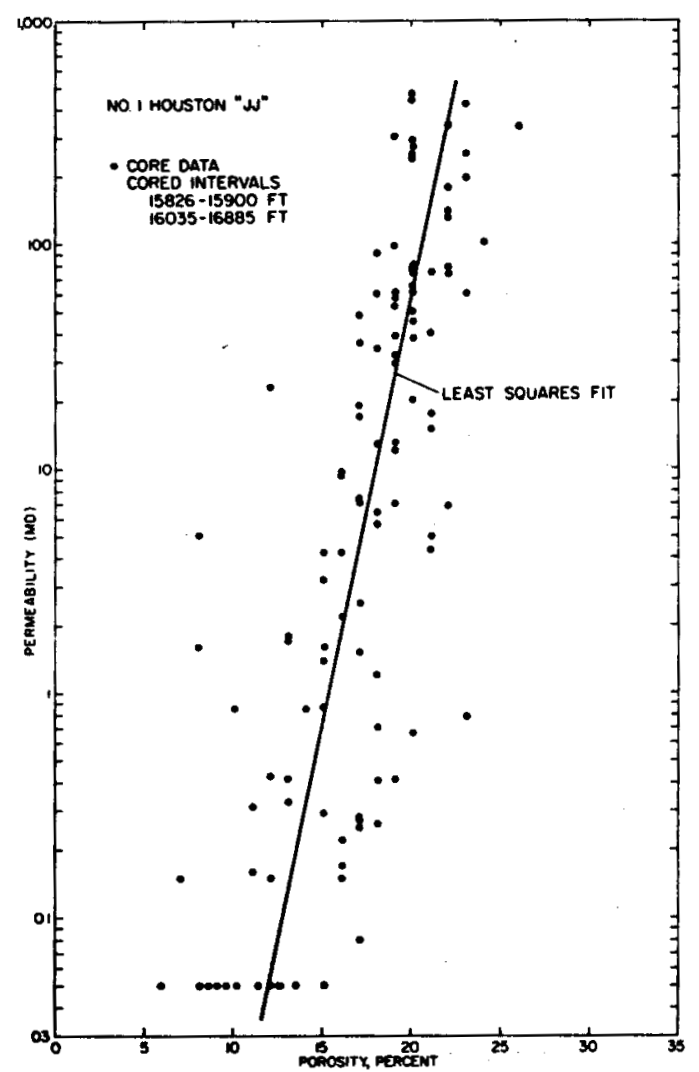

Figure 69. Porosity-permeability relationship from core measurements made at atmospheric pressure for Phillips No. 1 Houston "JJ," Chocolate Bayou field, Brazoria County, Texas. 


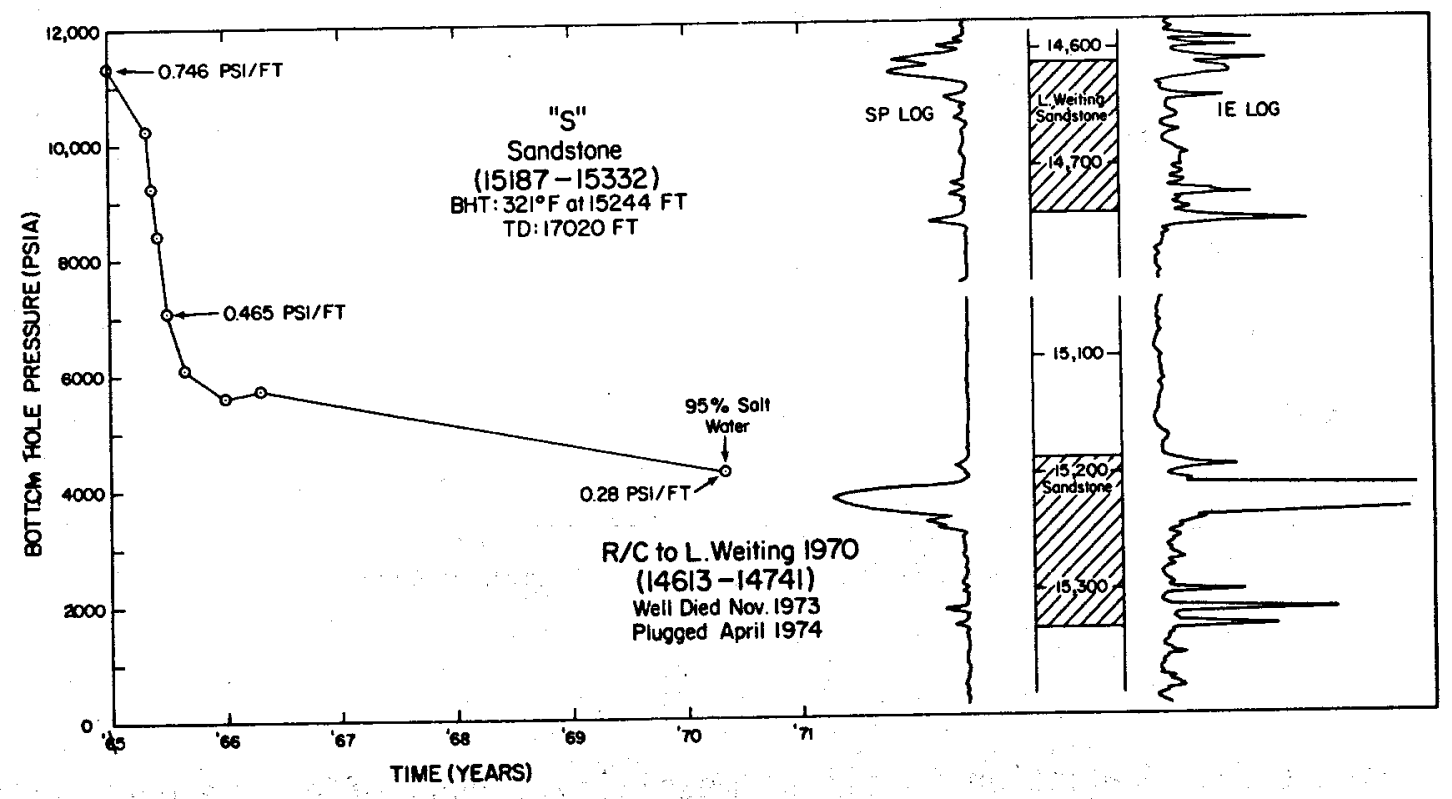

Figure 70. History of decline in bottom-hole pressure for No. 1 Houston "JJ," Chocolate Bayou field, Brazoria County, Texas.

Figure 71. Absolute permeability to water versus temperature for Berea sandstone under confining pressures up to 4,000 psi (Casse and Ramey, 1976). 


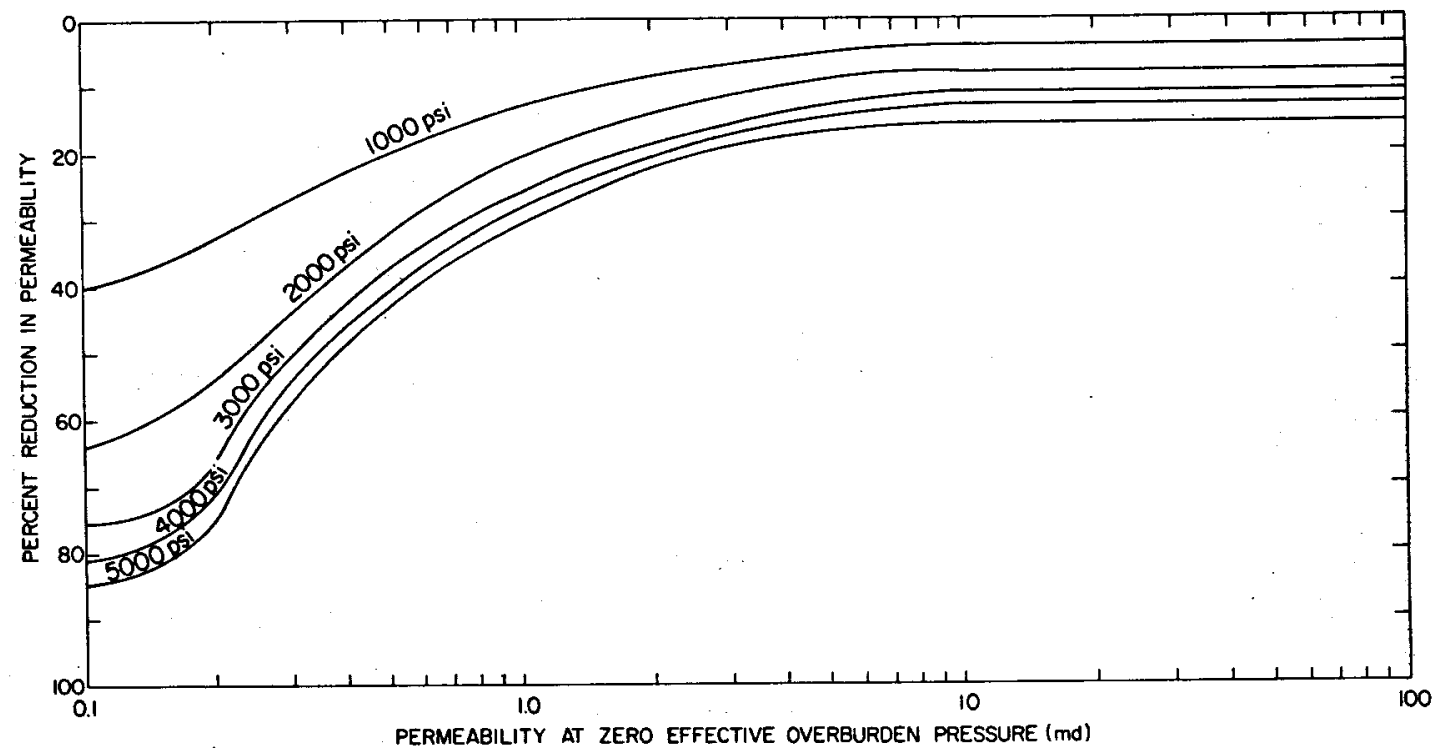

Figure 72. Reduction in oil permeability versus effective overburden pressure (McLatchie, Hemstock, and Young, 1958).

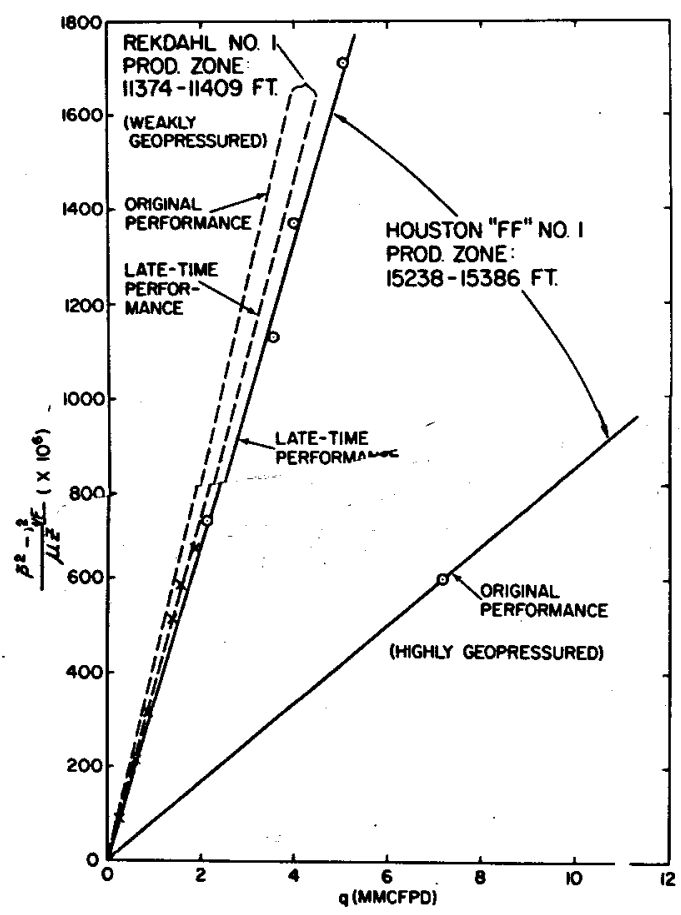

Figure 73. Comparison of original and late-time performance curves for highly geopressured and slightly geopressured reservoirs in Chocolate Bayou field, Brazoria County, Texas (Farina, 1976). 


\section{Permeability-Well Production Flow Tests}

The effective gas permeabilities determined from production flow tests are estimated to range from 1 to 6 millidarcys, and absolute permeabilities lie between 2 and 10 millidarcys for selected wells in the Chocolate Bayou field, Brazoria County, Texas.

Many of the sandstone reservoirs producing gas and condensate in the Chocolate Bayou field have pay thicknesses from 10 to 30 feet. Methods used for evaluating gas permeability from pressure buildup data and for converting gas permeability to absolute permeability are explained below. A method for computing permeability and skin factor from absolute open-flow potential tests (AOFPT) is also discussed. Agreement between permeabilities obtained from pressure buildup tests and from AOFPT is not always good, as shown by comparative data for several wells located in the Chocolate Bayou field (table 1). Permeability values from pressure buildup data range from 1.6 to 16.5 millidarcys and those from AOFPT vary from 1.4 to 131 millidarcys. The general quality and scatter of data from AOFPT for gas wells in Brazoria County make the validity of these permeabilities questionable. The general performance characteristics of gas wells suggest that a conservative interpretation of permeability data should be made. Hence, it is concluded that the effective permeabilities probably lie between 1 and 6 millidarcys, and absolute permeabilities are estimated to range from 2 to about 10 millidarcys. It is important to note that these permeability data are for relatively tight, thin, gas-bearing reservoirs. It is expected that the thicker and more porous water reservoirs in the Austin Bayou Prospect will have higher permeabilities.

Pressure buildup analysis-Effective permeability of a reservoir can be estimated from the rise in bottom-hole pressure (BHP) when a producing well is shut in. The method is valuable because effective permeability is based on actual performance of a well and represents average reservoir properties of a major portion of the drainage area, rather than the limited area around the well bore. Excessive pressure drop in the vicinity of the well bore (skin effect) detracts from the producing capability of the well. Skin effect is commonly the result of damages sustained by drilling, completion, and production practices and probably extends a distance of less than 20 feet from the well. The method for evaluating effective permeability involves equations which define the buildup characteristics for the shut-in well as functions of time, production rate prior to shut-in, radius of drainage of the well, compressibility and viscosity of the reservoir fluid, and porosity and permeability of the drainage area.

Table 1. Examples of effective permeabilities and skin factors computed from flow tests made early in life of wells in Chocolate Bayou field, Brazoria County, Texas.

\begin{tabular}{|c|c|c|c|c|c|c|c|c|c|}
\hline Well Name & Perforated Zone & $\begin{array}{l}\text { BHP } \\
\text { (psia) }\end{array}$ & $\underset{\text { (feet) }}{\mathrm{H}}$ & $\begin{array}{c}\underset{K h}{\mathrm{BH}} \\
(\mathrm{md}-\mathrm{ft})\end{array}$ & $\begin{array}{l}\text { Buildup } \\
K \\
\text { (md) }\end{array}$ & S & $\begin{array}{c}(4-p t \\
K h \\
(m d-f t)\end{array}$ & $\begin{array}{l}\text { t. Tests } \\
\mathrm{K} \\
(\mathrm{md})\end{array}$ & s) $s$ \\
\hline $\begin{array}{l}\text { Houston "FF" No. } 1 \\
\text { Houston "X" No. } 1 \\
\text { Banfield No. } 1 \\
\text { Gardiner No. } 1 \\
\text { Houston "W" No. } 1 \\
\text { Rekdahl No. } 1 \\
\text { Houston "EE" No. } 1 \\
\text { Millington No. } 1 \\
\text { Houston "M" No. } 2\end{array}$ & $\begin{array}{l}15,239-15,384 \\
12,099-12,110 \\
10,540-10,550 \\
11,722-11,786 \\
12,089-12,108 \\
11,376-11,397 \\
14,641-14,724 \\
11,015-11,022 \\
11,396-11,404\end{array}$ & $\begin{array}{r}12,420 \\
8,623 \\
5,630 \\
7,575 \\
5,730 \\
5,290 \\
12,422 \\
4,515 \\
2,572\end{array}$ & $\begin{array}{l}29 \\
10 \\
10 \\
25 \\
14 \\
8 \\
12 \\
25 \\
8\end{array}$ & $\begin{array}{l}113 \\
128^{* *} \\
165 \\
148 \\
- \\
14 \\
40 \\
-\end{array}$ & $\begin{array}{c}3.9 \\
12.8^{* *} \\
16.5 \\
5.2 \\
-\overline{7} \\
1.7 \\
-6 \\
-\end{array}$ & $\begin{array}{c}0 \\
3 \\
11 \\
3 \\
- \\
8 \\
- \\
- \\
-\end{array}$ & $\begin{array}{c}1430^{*} \\
12 \\
31 \\
34 \\
1840 \\
225^{*} \\
18^{*} \\
- \\
20\end{array}$ & $\begin{array}{l}49^{*} \\
1.2 \\
3.1 \\
1.4 \\
131 \\
28^{*} \\
1.5^{*} \\
- \\
2.5\end{array}$ & $\begin{array}{r}65 \\
-5 \\
0 \\
-2 \\
49 \\
14 \\
-2 \\
- \\
-\end{array}$ \\
\hline
\end{tabular}


The method of Horner (1951) involves plotting the buildup of reservoir pressure $P_{r}{ }^{2}$ as a function of a time ratio $(T+\Delta t / \Delta t)$, where $T$ is the length of the producing time before shut in, and $\Delta t$ is the shut-in period of time. A semilog plot of this pressure buildup data should result in a straight line with slope $M$ that is inversely proportional to the mean formation permeability as indicated by the relation:

$$
K h=\frac{1637 T_{r} q \mu z}{M}
$$

Equations for the skin factor (S) and Estimated Damage Ratio(EDR)also make use of slope M.

$$
\begin{aligned}
S= & 1.151\left[\frac{\bar{P}_{r}^{2} 1 \text { hour }-P_{w f}^{2}}{M}\right. \\
& \left.-\log \left[\frac{q T_{r} z \bar{P}_{r}}{1.033 M h \phi r_{w}^{2}}\right)\right] \\
E D R= & \frac{P_{r}^{2}-P_{w f}^{2}}{M(\log T+2.65)}
\end{aligned}
$$

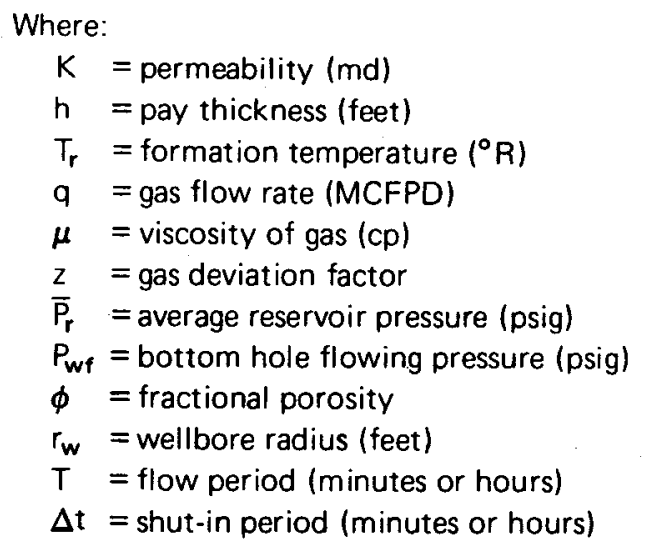

As an example, a pressure buildup plot for the No. 1 Gardiner, Chocolate Bayou field, Brazoria County, gives a slope $M=0.58 \times$ $10^{6}$ psig per cycle (fig. 74). The effective permeability for this well was computed to be 5.2 millidarcys, and the EDR was 1.3. Values of formation parameters used for these calculations are given below: flow time $(T) \ldots \ldots \ldots \ldots \ldots 60$ minutes flow rate $(q) \ldots \ldots \ldots \ldots$ 1,765.MCFPD depth of producing sand ... 11,779 feet sand thickness $(h) \ldots \ldots \ldots \ldots 25$ feet bottom-hole temperature ....... $260^{\circ} \mathrm{F}$ gravity of gas ................ 0.654 viscosity of gas $(\mu) \ldots \ldots \ldots .0 .03 \mathrm{cp}$ gas deviation factor $(z) \ldots \ldots \ldots \ldots 1.21$ reservoir pressure $\left(P_{r}\right) \ldots \ldots$. . 575 psig formation flowing pressure in well bore $\left(P_{w 1}\right)$ 7,347 psig

Multipoint open-flow potential tests-An important source of flow data is from absolute open-flow potential tests (AOFPT), commonly called four-point open-flow potential tests. The AOFPT are a series of measurements of flowing bottom-hole pressures made with the well flowing at different rates. The Texas Railroad Commission requires that AOFPT be made in gas wells; the results aid in determining the allowable flow rate. The data can be used to determine the Kh product and skin factor by analytical procedures described by Odeh and Jones (1965). Usefulness of the technique is highly dependent on the accuracy of the pressure measurements.

The $\mathrm{Kh}$ product and skin factor are determined from:

$$
K h=\frac{28,958 \mu_{g} B_{g}}{m^{\prime}}
$$

and

$$
\begin{aligned}
S & =1.151\left[\frac{b^{\prime}}{m^{\prime}}\right. \\
& \left.-\log \frac{k_{g}}{\phi \mu_{g} c_{g} r_{w}^{2}}+3.23\right]
\end{aligned}
$$

Where:

$$
\begin{aligned}
& \mu_{g}=\text { viscosity of gas }(\mathrm{cp}) \\
& \mathrm{k}_{0}=\text { permeability to gas }(\mathrm{md}) \\
& \phi=\text { fractional porosity } \\
& \mathrm{C}_{g}=\text { compressibility of gas }\left(\mathrm{psi}^{-1}\right) \\
& \mathrm{r}_{w} \quad=\text { radius of well (feet) } \\
& \mathrm{B}_{\mathrm{g}} \quad=\text { formation volume factor }
\end{aligned}
$$

$m^{\prime}$ is the slope and $b^{\prime}$ is the intercept of versus $\sum_{j=1}^{n}\left(\frac{q_{j}-q_{j-1}}{q_{n}}\right) \log \left(t_{n}-t_{j-1}\right)$ 
Details of calculations required in the analysis of multi-point open-flow potential test data are given by Matthews and Russell (1967). Results from AOFPT analysis of data for the Phillips No. 1 Gardiner give a permeability of 1.4 millidarcys and a skin factor of -2 (fig. 75). These results agree fairly well with those from pressure buildup data given earlier where $\mathrm{K}$ was 5.2 millidarcys and $\mathrm{S}$ was 3 .

Calculation of absolute permeability-Absolute permeability is determined by flow tests on rocks that are fully saturated by a single fluid. Presence of other fluids within the rock reduces the ability of the first fluid to flow. This reduced permeability is called the effective permeability to the first fluid. Relative permeability is the ratio of the effective permeability to the absolute permeability and varies from 0 to 1 . Relative permeability is influenced by the portion of the pore volume occupied by each fluid and by how the fluids are distributed and segregated within the rock. Segregation is a function of saturation levels and the wetting characteristics of the rock and the respective fluids. Most reservoir rocks are considered to be water wet because they were originally laid down in a water environment. Where gas and water are the predominant reservoir fluids, gas is the nonwetting phase and, of course, water is the wetting phase.

The effective gas permeability $(\mathrm{Kg})$ determined from pressure buildup tests was estimated to lie between 1 and 6 millidarcys for wells in Chocolate Bayou field. Relative permeability to the non-wetting phase (Krn) was calculated from the relationship below (Rose, 1949).

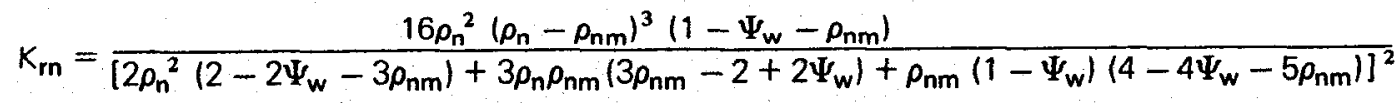

$$
\begin{aligned}
& \text { where } \\
& K_{r n}=K_{r g}=\text { relative permeability } \\
& \text { to gas } \\
& \rho=\text { fluid saturation } \\
& \text { (fractional) } \\
& \Psi \quad=\text { immobile phase } \\
& \text { saturation (fractional) } \\
& n \quad=\text { non-wetting phase } \\
& \text { w = wetting phase } \\
& m=\text { minimum saturation } \\
& \text { values attained } \\
& \text { under dynamic } \\
& \text { flow conditions } \\
& \text { (fractional). }
\end{aligned}
$$


It is assumed that the immobile wetting phase saturation $\Psi w$ is 30 percent, and $\rho n$ is 60 percent since some water production (about 10 percent) is observed. The value of 0.18 for $\rho n m$ is based on a gas recovery efficiency of 70 percent assumed for Gulf Coast wells, that is, $\rho n m=(1-0.7)(.6)=$ 0.18 . Numerical evaluation of $\mathrm{Krg}$ in equation (6) gives a value of 0.66 .

$$
\begin{aligned}
& \text { Absolute permeability } \mathrm{K}=\frac{\mathrm{K}_{\mathrm{g}}}{\mathrm{K}_{\mathrm{rg}}}, \\
& \text { hence } \mathrm{K}_{1}=\frac{1}{0.66}=1.5 \mathrm{md} \text { and } \\
& \mathrm{K}_{2}=\frac{6}{0.66}=9.1 \mathrm{md}
\end{aligned}
$$

where $K_{1}$ and $K_{2}$ are the low and high values of absolute permeability based on the range of effective gas permeabilities determined from production flow tests. 


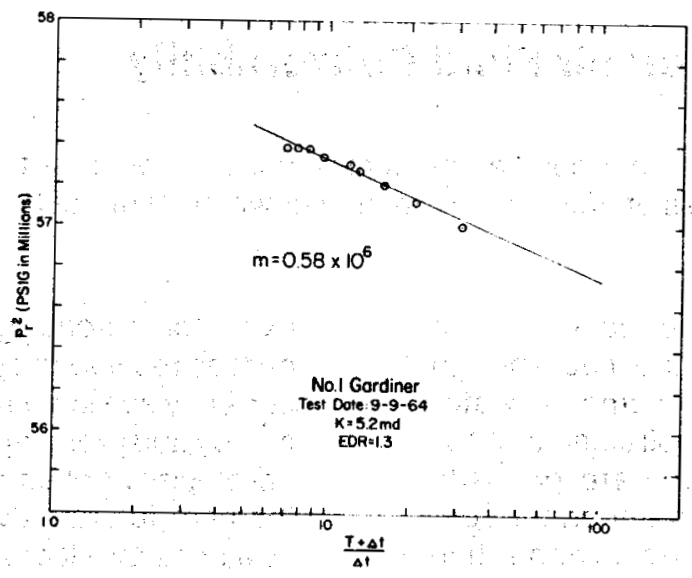

Figure 74. Pressure buildup for gas produced from lower Weiting sandstones Phillips No. 1 Gardiner, Chocolate Bayou field, Brazoria County, Texas.

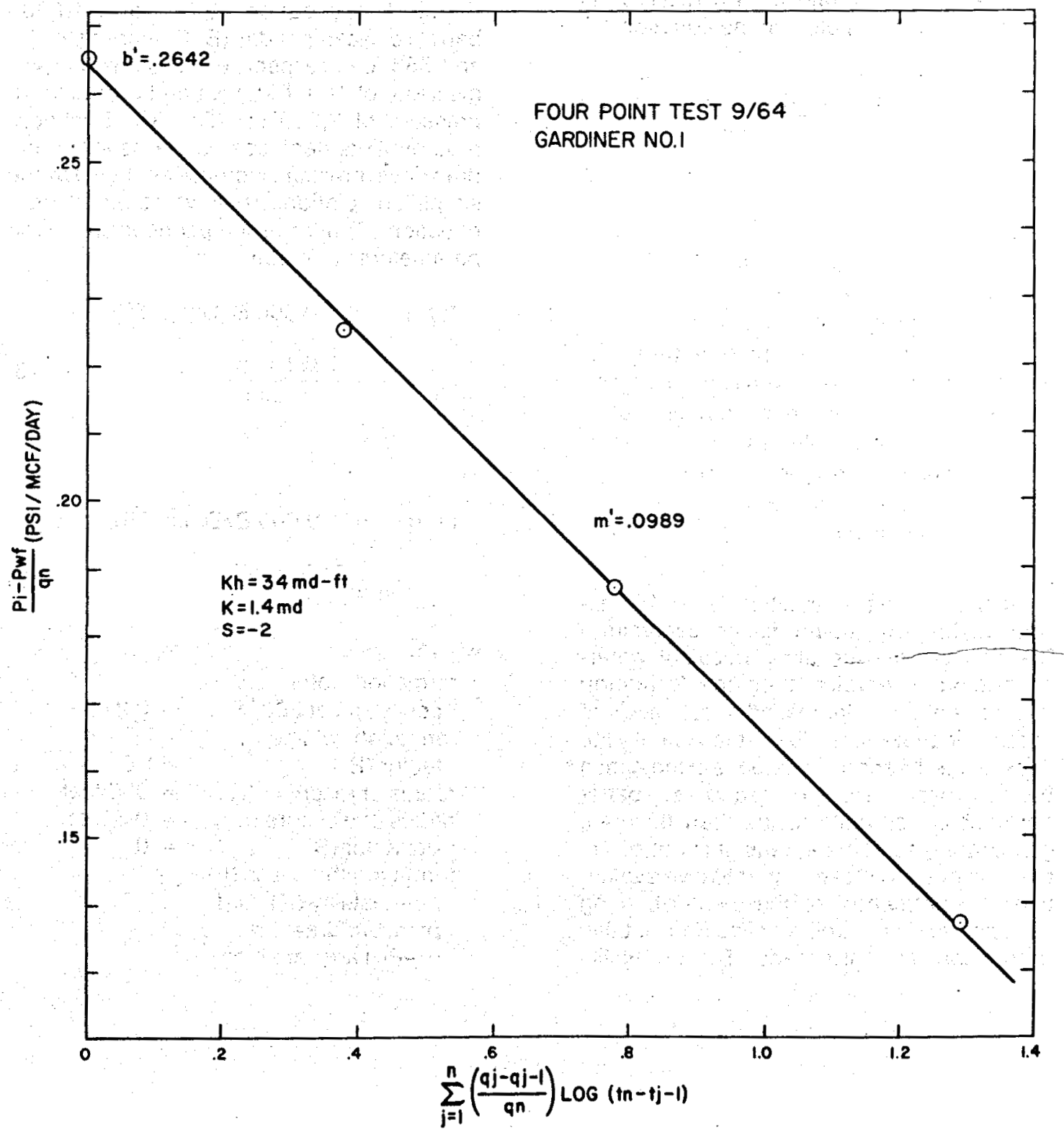

Figure 75. Data from open-flow potential tests used to calculate Kh and $\mathbf{S}$ for Phillips No. 1 Gardiner, Chocolate Bayou field, Brazoria County, Texas. 


\section{Permeability-Reservoir Fluid Deliverability}

A flow rate of 40,000 barrels per day can be achieved in a reservoir with a permeability of 10 millidarcys, a sand thickness of 383 feet, and a drawdown pressure of $2,000 \mathrm{psi}$.

It is assumed that the geopressured reservoir selected for testing has enough porosity to contain the volume of water required for long range requirements of the geothermal project. Adequate porosity (about 20 percent) was an important consideration in selecting the prospective geothermal test-well site. However, permeability is the most critical factor affecting fluid production rates.

The water flow rate from a reservoir is controlled by parameters in the equation.

$$
q=\frac{K h\left(\bar{P}_{r}-P_{w f}\right)}{141.2 \mu B\left(\ln r_{e} / r_{w}-.75+S\right)}
$$

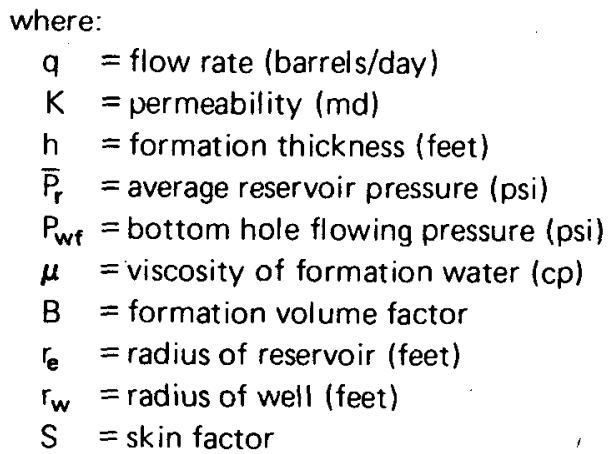

If the low permeabilities ( 2 to 10 millidarcys) found in gas-producing reservoirs in Brazoria County are also typical of waterproducing reservoirs, then the formation thickness must be increased substantially to obtain adequate water flow rates. Actually the thick, water-bearing sandstones in the Austin Bayou Prospect are expected to have better permeability characteristics than the thin, gas-bearing sandstone beds. It is not possible, however, to make a quantitative evaluation of the permeability of these water-bearing sandstones until a well is drilled and suitable production tests are made. The possibility exists for increasing the producing capacity of deep reservoirs by a factor of 1 to $1 \frac{1}{2}$ using currently available hydraulic fracturing technology and propping materials. The expected development of stronger propping agents in the near future may result in increasing the flow rates by a factor of $2 \frac{1}{2}$ to 3 (Podio, Gray, Isokrari, Knapp, Silberberg and Thompson, 1976).

Estimates of sandstone thickness required to produce 20,000 and 40,000 barrels of water per day $(B / D)$ amount to 191 and 383 feet, respectively, assuming a permeability of 10 millidarcys and a drawdown pressure of 2,000 psi (fig. 76). Thickness requirements decrease as permeability and drawdown pressure increase as shown by the simplified relations (below) obtained from equation (7) after assumptions for reservoir parameters are made.

$$
\begin{aligned}
\text { for } \mathrm{q} & =20,000 \mathrm{~B} / \mathrm{D} \text { (fig. 76): } \\
h & =\frac{3.828 \times 10^{6}}{K(\Delta P)} \\
\text { for } \mathrm{q} & =40,000 \mathrm{~B} / \mathrm{D} \text { (fig. 76): } \\
h & =\frac{7.656 \times 10^{6}}{K(\Delta P)}
\end{aligned}
$$

where:

$$
\begin{aligned}
& \text { formation water vis- } \\
& \operatorname{cosity}(\mu) \text { at } 300^{\circ} \mathrm{F} \quad=0.2 \mathrm{cp} \\
& \text { formation volume } \\
& \text { factor }(B) \quad=1.0 \\
& \text { radius of reservoir }\left(r_{e}\right)=930 \text { feet } \\
& \text { radius of wellbore }\left(r_{w}\right)=0.5 \text { feet } \\
& \text { skin factor (S) } \quad=0 \\
& \text { formation thickness }(h) \text {, } \\
& \text { permeability }(K) \text {, and } \\
& \text { pressure drawdown } \\
& (\bar{P}-\mathrm{Pw}) \text { are variables. }
\end{aligned}
$$



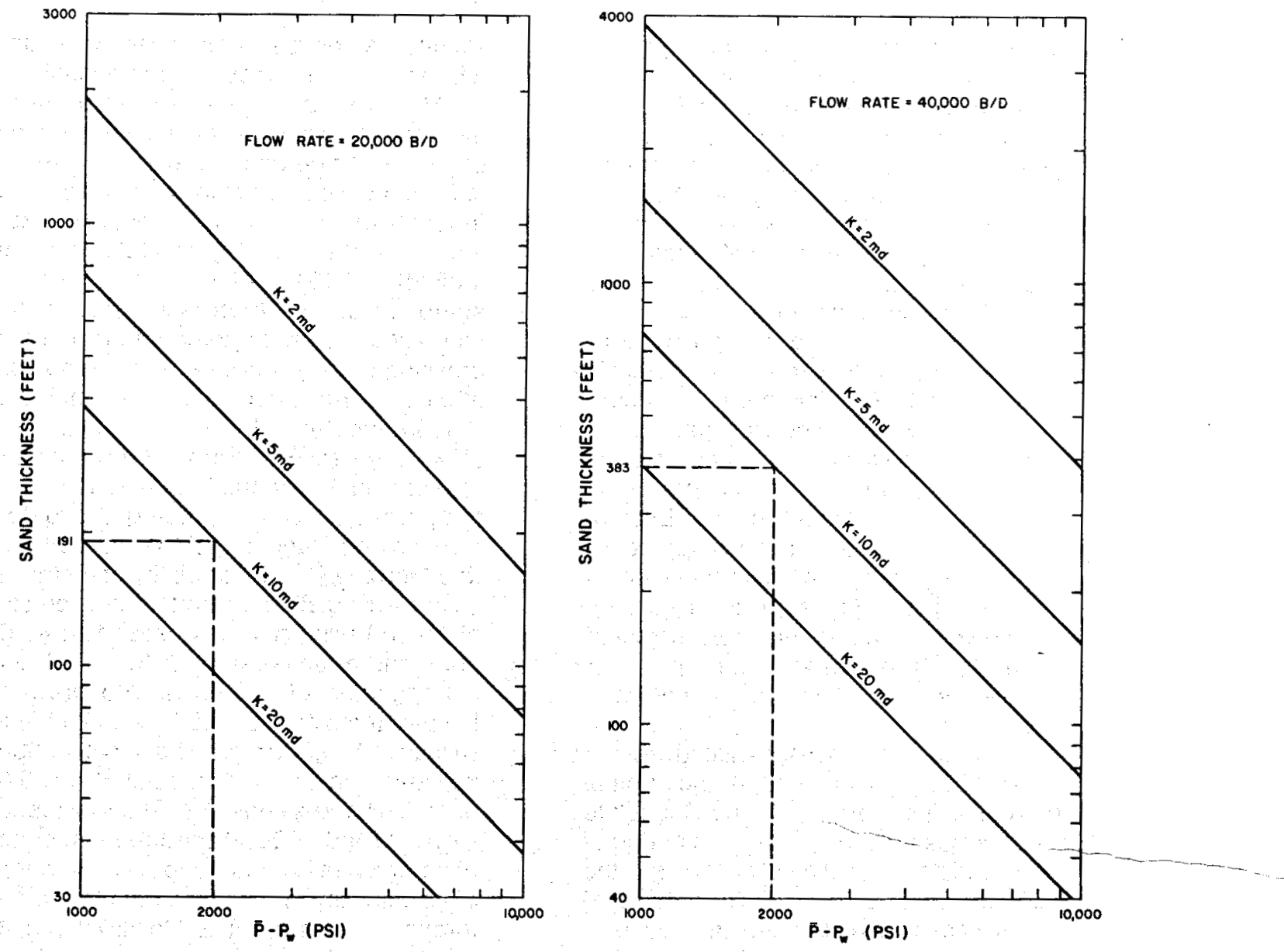

Figure 76. Sand thickness required to produce (a) 20,000 and (b) 40,000 barrels of water per day as a function of drawdown pressure for permeabilities from 2 to 20 millidarcys. 


\section{Salinity and Methane Content}

Salinities vary from 40,000 to $80,000 \mathrm{ppm}$, and methane content may range from 25 to 45 cubic feet per barrel for formation waters commonly found in the Chocolate Bayou field, Brazoria County, Texas.

Salinity of formation waters - Salinity variations observed in formation waters of Chocolate Bayou field, Brazoria County, Texas, are dependent on the history of water movement in the reservoir and are influenced by the following processes (Fowler, 1970).

1. Selective retention of ions by compacting shales acting as membranes may dilute original formation waters as reservoir pressures decline.

2. Dilution may also be caused by condensation of water vapor from gas that is being produced. This normally occurs when gas-water ratios are high.

3. Increases in salinity may occur in a reservoir when more saline waters break through from adjacent aquifers. Entry of water from other aquifers can occur when permeability barriers break down as a result of pressure decline in the reservoir. If the waters from adjacent aquifers are fresher than reservoir water, salinity of the produced water decreases.

As a result of processes listed above, Fowler (1970) observes that the typical pattern of salinity variation in the Chocolate Bayou field is one of dilution over a period of time. The history of salinity variations in the area, however, is complex, and exceptions to the above observation are known to occur.

Fowler (personal communication) selected salinities that he believed were typical of the connate waters of a number of formations at depths ranging from 8,600 to 12,833 feet. These salinities average about $40,000 \mathrm{ppm}$ at depths of 8,600 to 10,000 feet, then increase sharply to values ranging from 50,000 to $87,000 \mathrm{ppm}$ at depths of 11,000 to 12,800 feet (fig. 77 ). The observed increase in salinity with depth in the geopressured formations of the Chocolate Bayou field is at variance with the strong dilution of salinity noted by Schmidt (1973) in the geopressured zone of the Manchester field, Calcasieu Parish, Louisiana (fig. 78). These variations in salinity values between different fields in different locations may not be unusual.

Methane content-The solubility of methane in formation water is influenced by pressure, temperature, and salinity. At constant temperature, solubility increases as a function of pressure, as shown by experimental data (fig. 79) of Culberson and McKetta (1951). At constant pressure, solubility at first decreases slowly, then increases rapidly as temperature rises. Increasing salinity reduces methane solubility at different rates depending on temperature (fig. 80), as shown by Dodson and Standing (1944). For salinities up to $40,000 \mathrm{ppm}$, the rate of solubility reduction decreases as the temperature rises. By using the data of Dodson and Standing (1944) and Culberson and McKetta (1951), solubility of methane is estimated (fig. 81) for a bottom-hole pressure of 10,000 psia, salinities exceeding 40,000 $\mathrm{ppm}$, and a temperature of $300^{\circ} \mathrm{F}$. A linear extrapolation of curves is also drawn for temperatures of $100^{\circ}, 200^{\circ}$, and $250^{\circ} \mathrm{F}$ to a salinity of $100,000 \mathrm{ppm}$. The curve for $300^{\circ} \mathrm{F}$ is also estimated and extrapolated to 100,000 ppm. Brill and Beggs (1975) show that at a salinity of $300,000 \mathrm{ppm}$ the aqueous solubility of natural gas is reduced to 20 to 30 percent of its solubility in pure water in the temperature range from about $90^{\circ}$ to $250^{\circ} \mathrm{F}$ (fig. 82).

Although the solubility of methane decreases as salinity rises, an increase in temperature in the geopressured zone (fig. 77) causes a small net increase in solubility in spite of the higher salinity. For example, in the hydropressure zone at a depth of 9,600 feet, the temperature is about $225^{\circ} \mathrm{F}$, the salinity is about $40,000 \mathrm{ppm}$, and the solubility. of methane (fig. 81) is about 29 standard cubic feet per barrel of water. In the geopressured zone at a depth of 12,500 feet, the salinity has increased to about $70,000 \mathrm{ppm}$, but the temperature has also increased to $275^{\circ} \mathrm{F}$, and the solubility of methane rises to 33 standard cubic feet per barrel of water. 


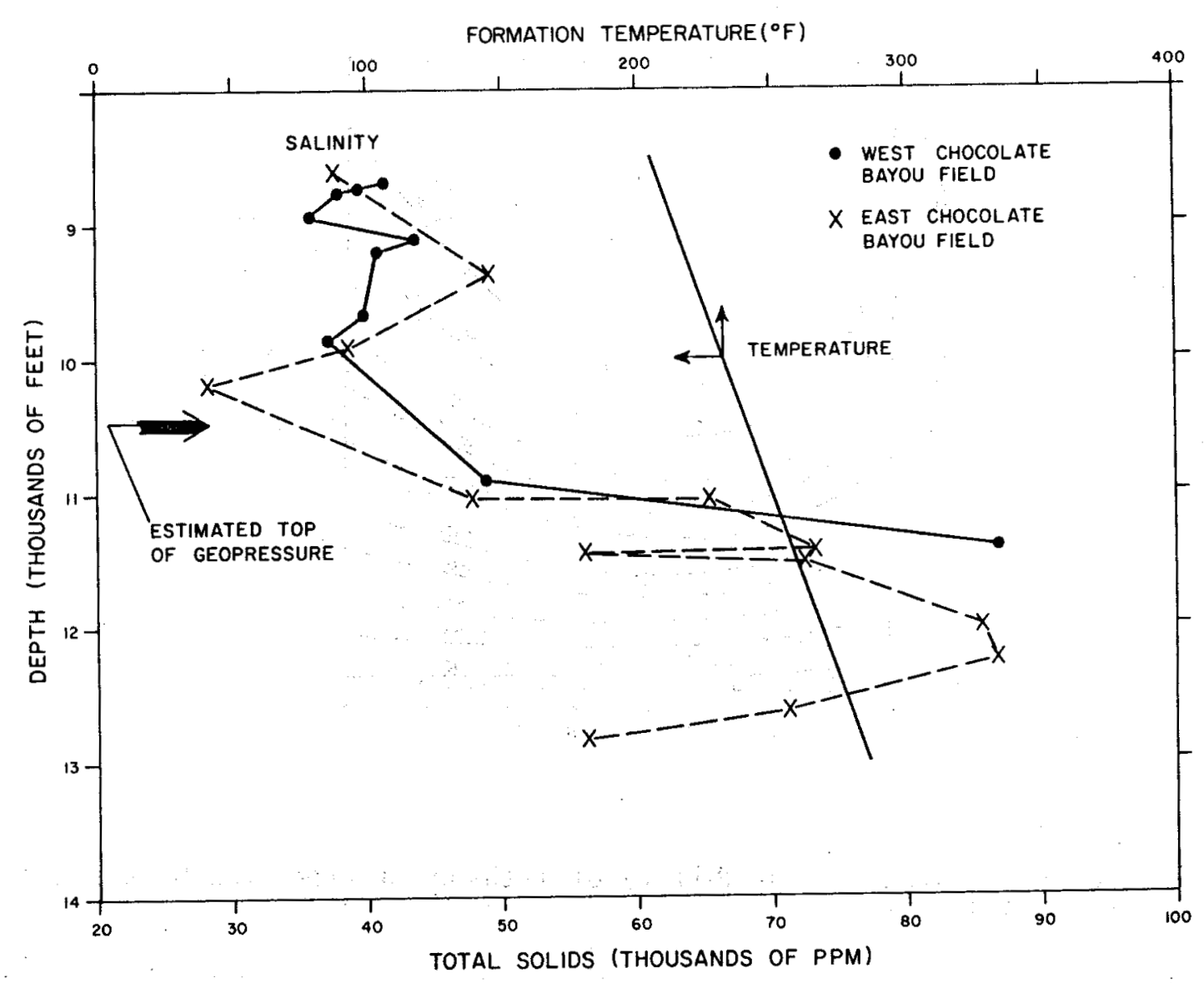

Figure 77. Salinity and temperature of formation waters, Chocolate Bayou field, Brazoria County, Texas.

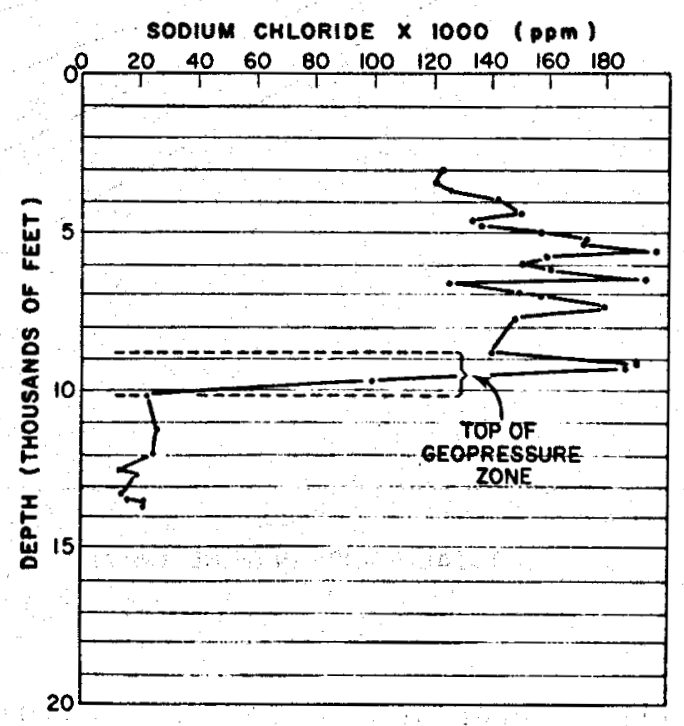

Figure 78. Change in formation water salinity with depth related to occurrence of the geopressured zone, Manchester Field, Calcasieu Parish, Louisiana (Schmidt, 1973). 


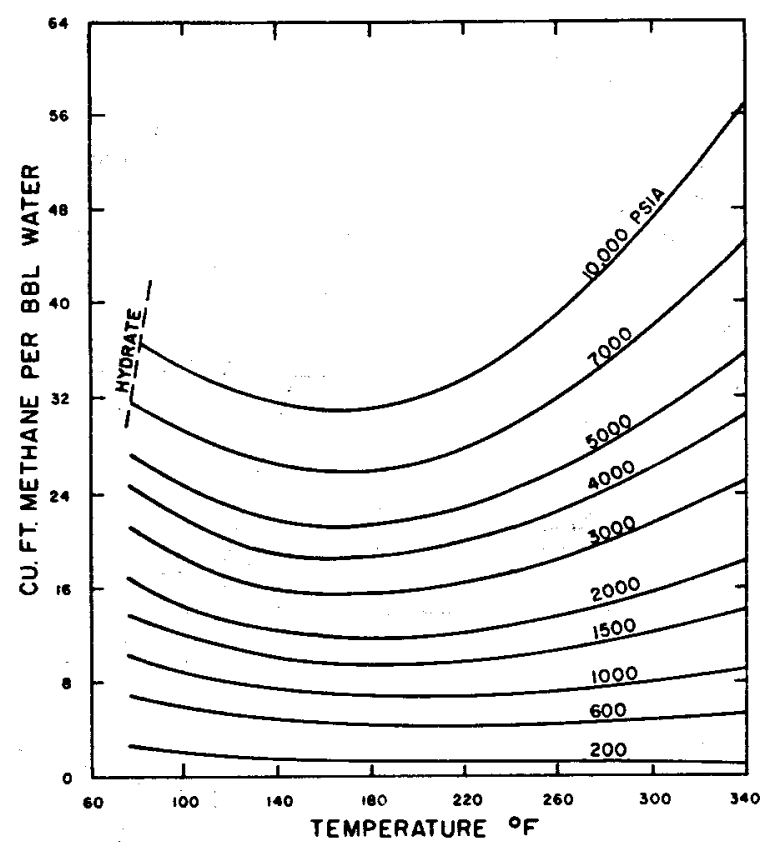

Figure 79. Volumetric solubility of methane in water (Cuiberson and McKetta, 1951).

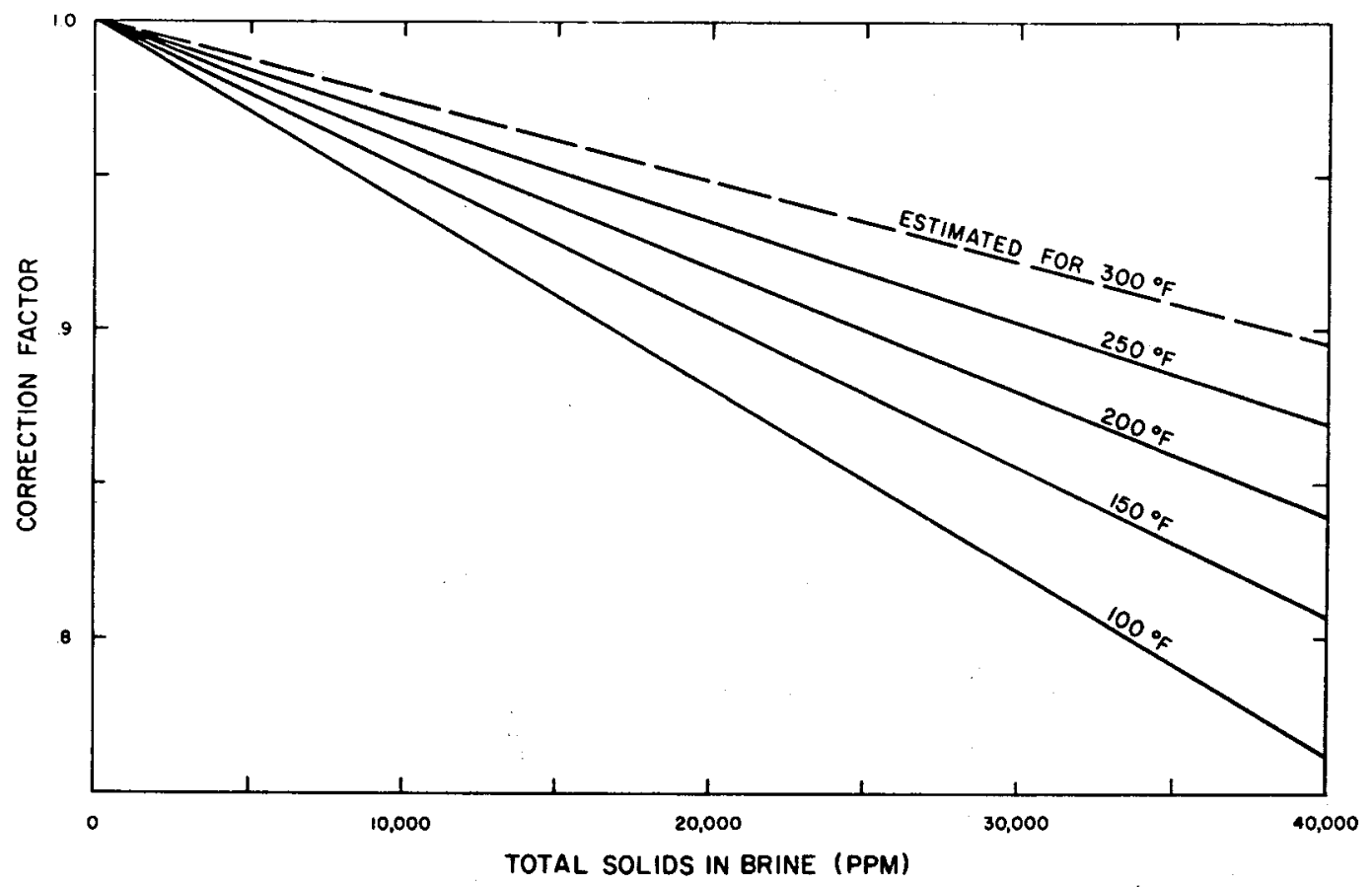

Figure 80. Solubility correction factor for salinity of formation water (Dodson and Standing, 1944). 


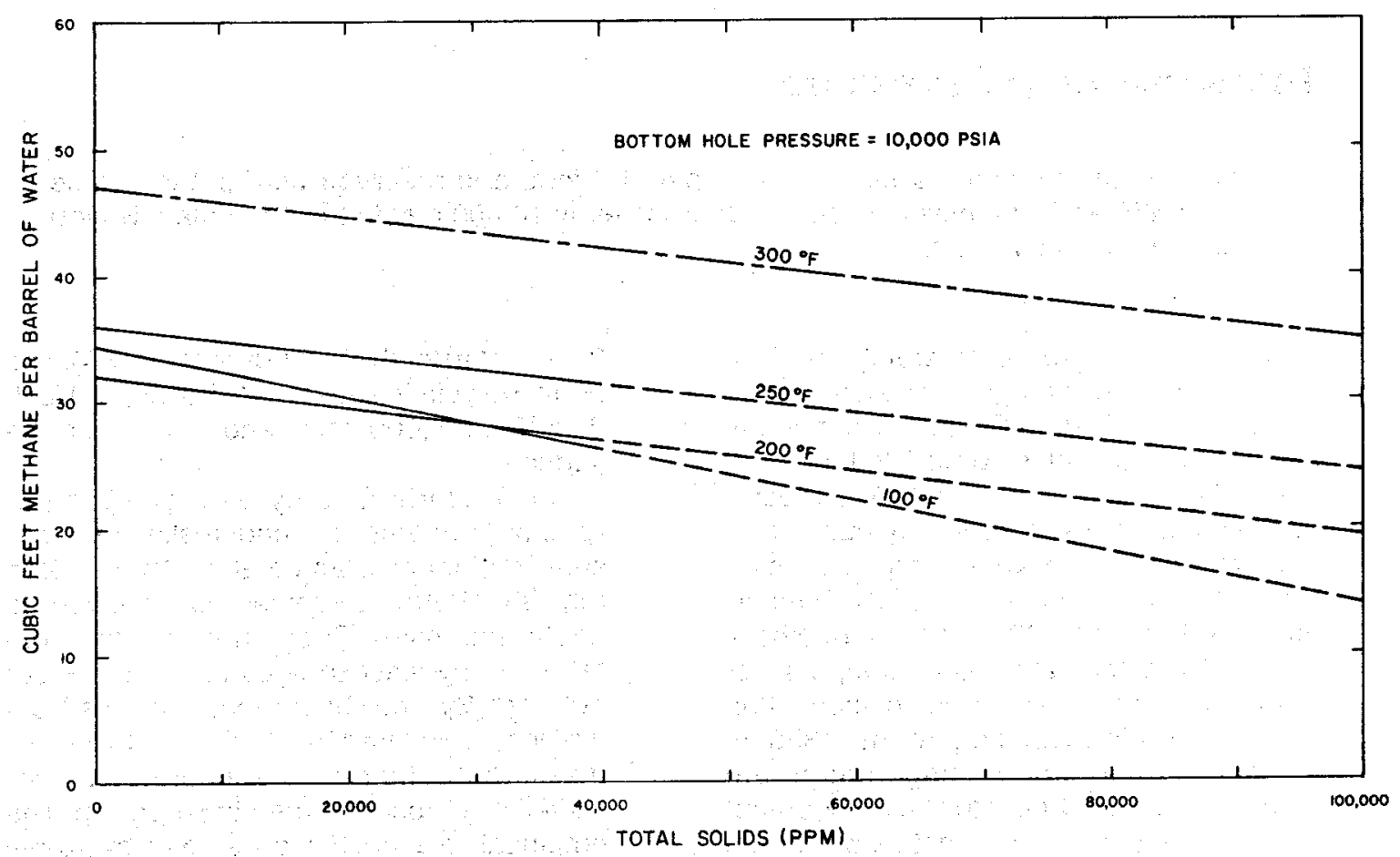

Figure 81. Effect of salinity and temperature on solubility of methane in water at constant pressure of 10.000 psi.

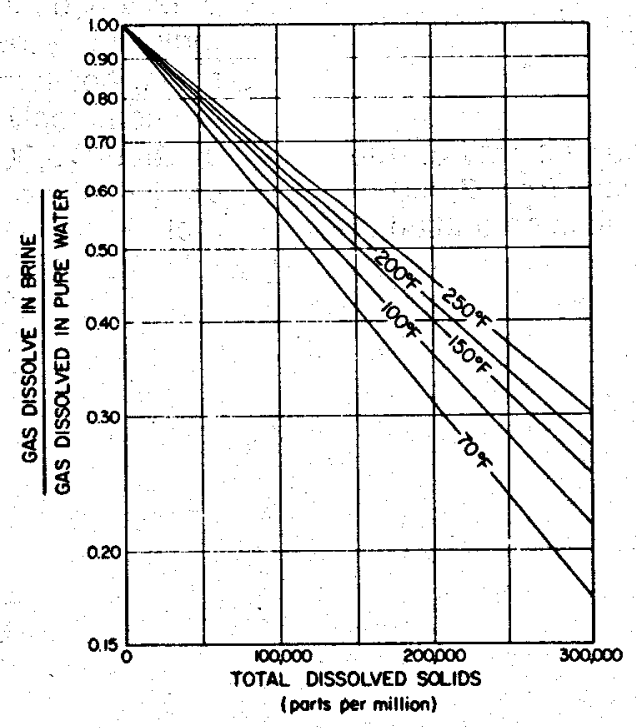

Figure 82. Effect of salinity on the amount of gas in solution when brine is fully saturated with gas (Brill and Beggs, 1975). 


\section{Temperature and Pressure}

The average geothermal gradient is $1.8^{\circ} \mathrm{F}$ per 100 feet, and reservoir fluid pressures lie between 0.465 and 0.98 psia per foot for depths below 10,000 feet in the Chocolate Bayou field, Brazoria County, Texas.

Geothermal gradients along the Gulf Coast are known to range from about $1.4^{\circ}$ to $2.4^{\circ} \mathrm{F}$ per 100 feet. In Brazoria County, the geothermal gradient is about $1.8^{\circ} \mathrm{F}$ per 100 feet, as indicated by bottom-hole temperatures measured just prior to production flow tests for a number of wells at depths ranging from 8,500 to 18,000 feet (fig. 83). Temperatures of $250^{\circ}$ and $300^{\circ} \mathrm{F}$ occur at depths of about 11,000 feet and 13,800 feet, respectively. Wells must be drilled to more than 16,000 feet to find temperatures near $350^{\circ} \mathrm{F}$. Measured bottom-hole temperatures are higher than those obtained from well logs that are corrected to approximate equilibrium temperatures according to the relation developed by Kehle (1971).

$$
\begin{aligned}
T_{E}= & T_{L}-8.819 \times 10^{-12} D^{3}-2.143 \\
& \times 10^{-8} D^{2}+4.375 \times 10^{-3} D-1.018
\end{aligned}
$$

where

$$
\begin{aligned}
T_{E} & =\text { equilibrium temperature }\left({ }^{\circ} \mathrm{F}\right) \\
T_{L} & =\text { Bottom-hole temperature from well } \\
& \text { logs }\left({ }^{\circ} \mathrm{F}\right) \\
D= & \text { depth (feet) }
\end{aligned}
$$

A plot of temperature corrections from the Kehle relationship for depths from 7,000 to 20,000 feet shows a maximum correction of $32.9^{\circ} \mathrm{F}$ at a depth of 13,000 feet (fig. 84). The correction diminishes to $7.4^{\circ} \mathrm{F}$ at 20,000 feet, $25.5^{\circ} \mathrm{F}$ at 7,000 feet, and zero near the surface.

In Brazoria County, computed equilibrium temperatures underestimate measured bottom-hole temperatures by $6^{\circ}$ to $20^{\circ}$ (fig. 83). Better agreement is observed as depth increases. Geothermal gradient established by least-squares fit is $1.98^{\circ} \mathrm{F}$ per 100 feet for equilibrium temperatures from well logs compared to $1.8^{\circ} \mathrm{F}$ per 100 feet for measured bottom-hole temperatures. Observed discrepancies are not surprising. The empirical relationship developed by Kehle (1971) is based on a statistical study of many wells over a wide area along the Gulf Coast and will not always agree with temperatures in local areas.

Reservoir-fluid pressures are an important aspect of geopressured aquifers because they control the primary driving forces that produce the geothermal waters. The effective overburden stress on the reservoir rock is controlled by fluid pressure; when this stress becomes excessive, compression occurs, the bulk volume of the formation is reduced, and subsidence may set in. Aquifers in the Chocolate Bayou field are commonly geopressured below a depth of about 10,000 feet (fig. 85). Geopressure gradients lie between 0.465 and 0.98 psia per foot. 


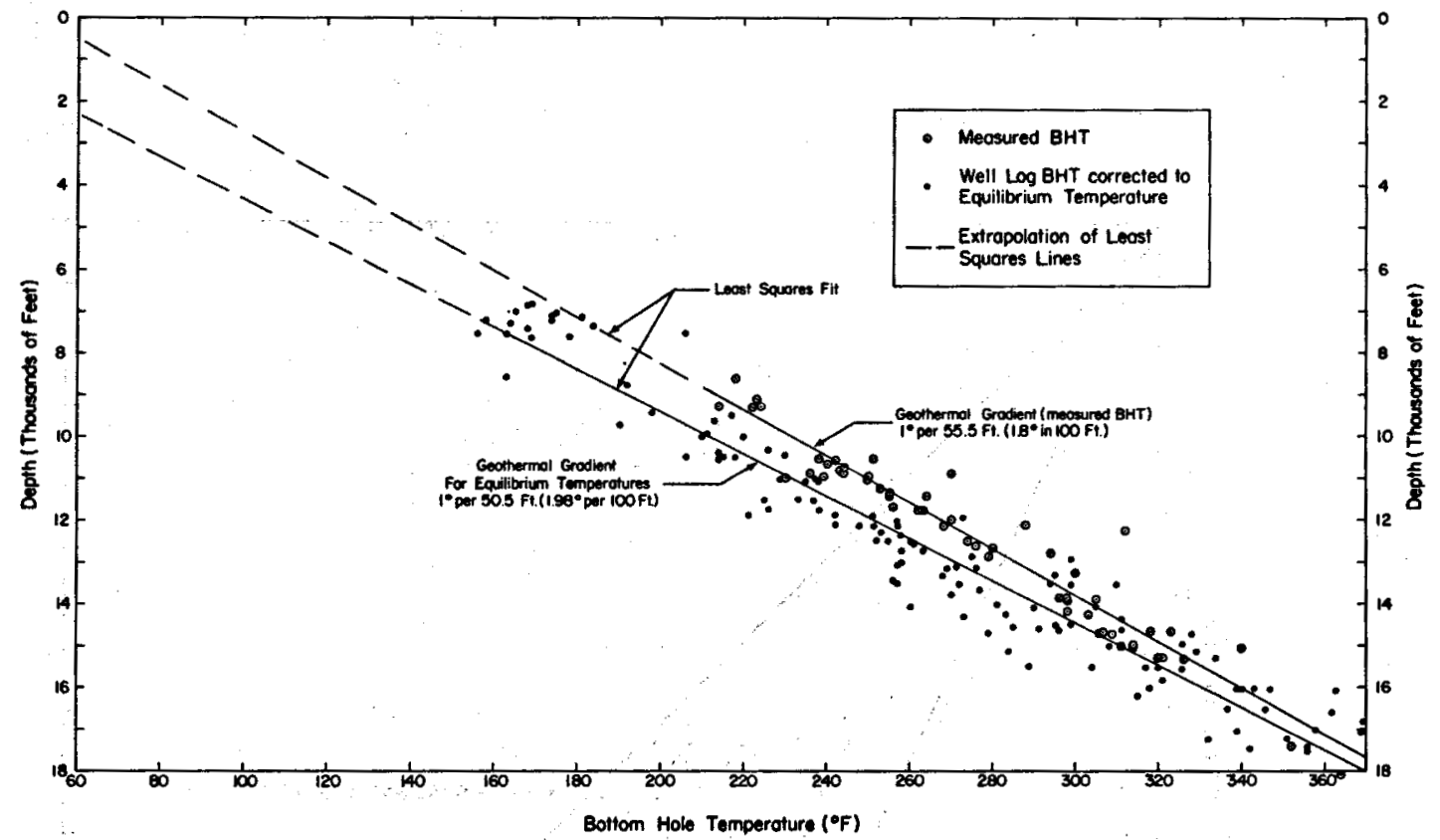

Figure 83. Comparison between measured bottom hole temperatures (BHT) and equilibrium temperatures calculated from well logs, Brazoria County, Texas.

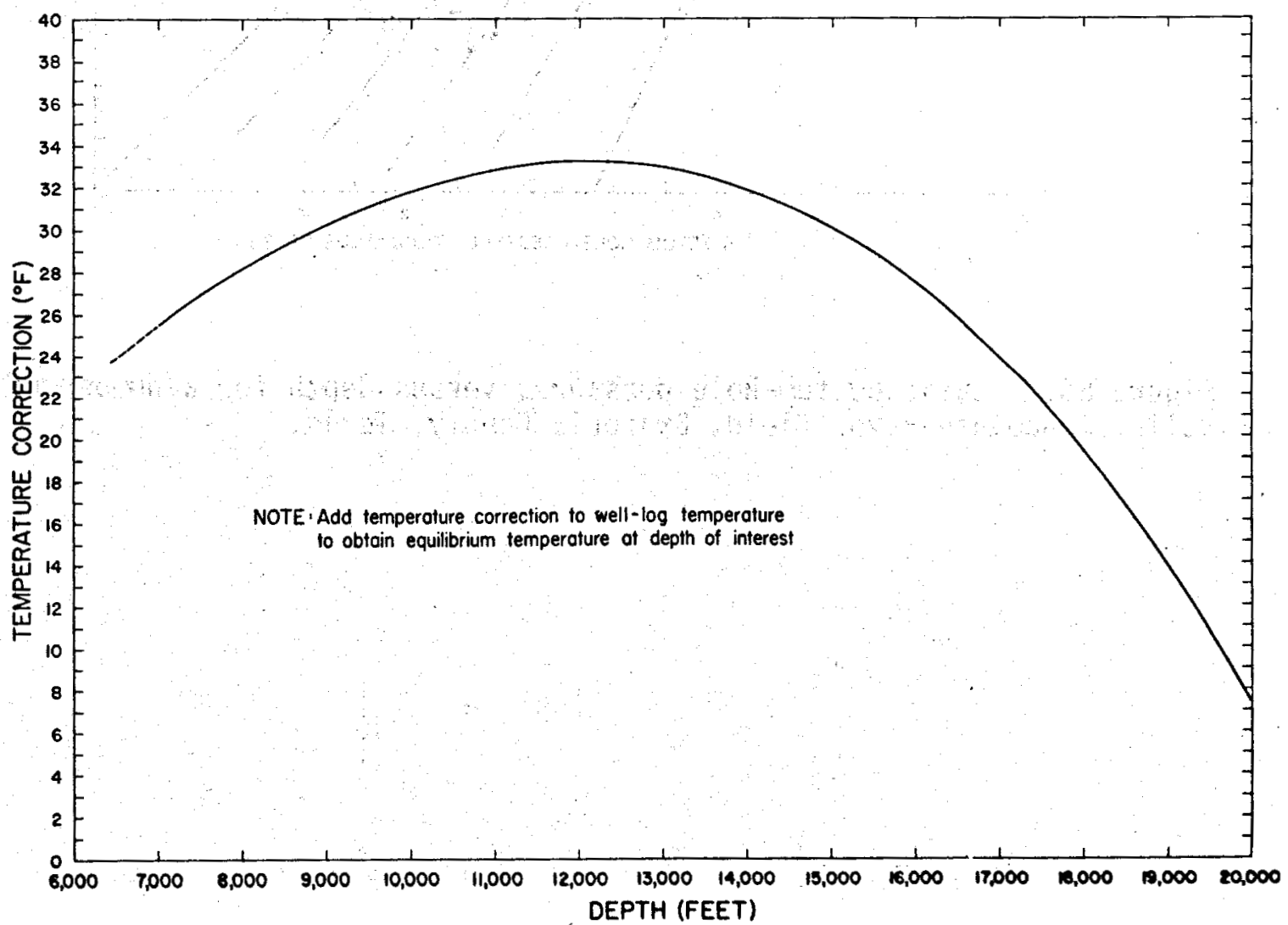

Figure 84. Temperature corrections as a function of depth for adjusting well-log temperatures to approximate equilibrium temperatures. 


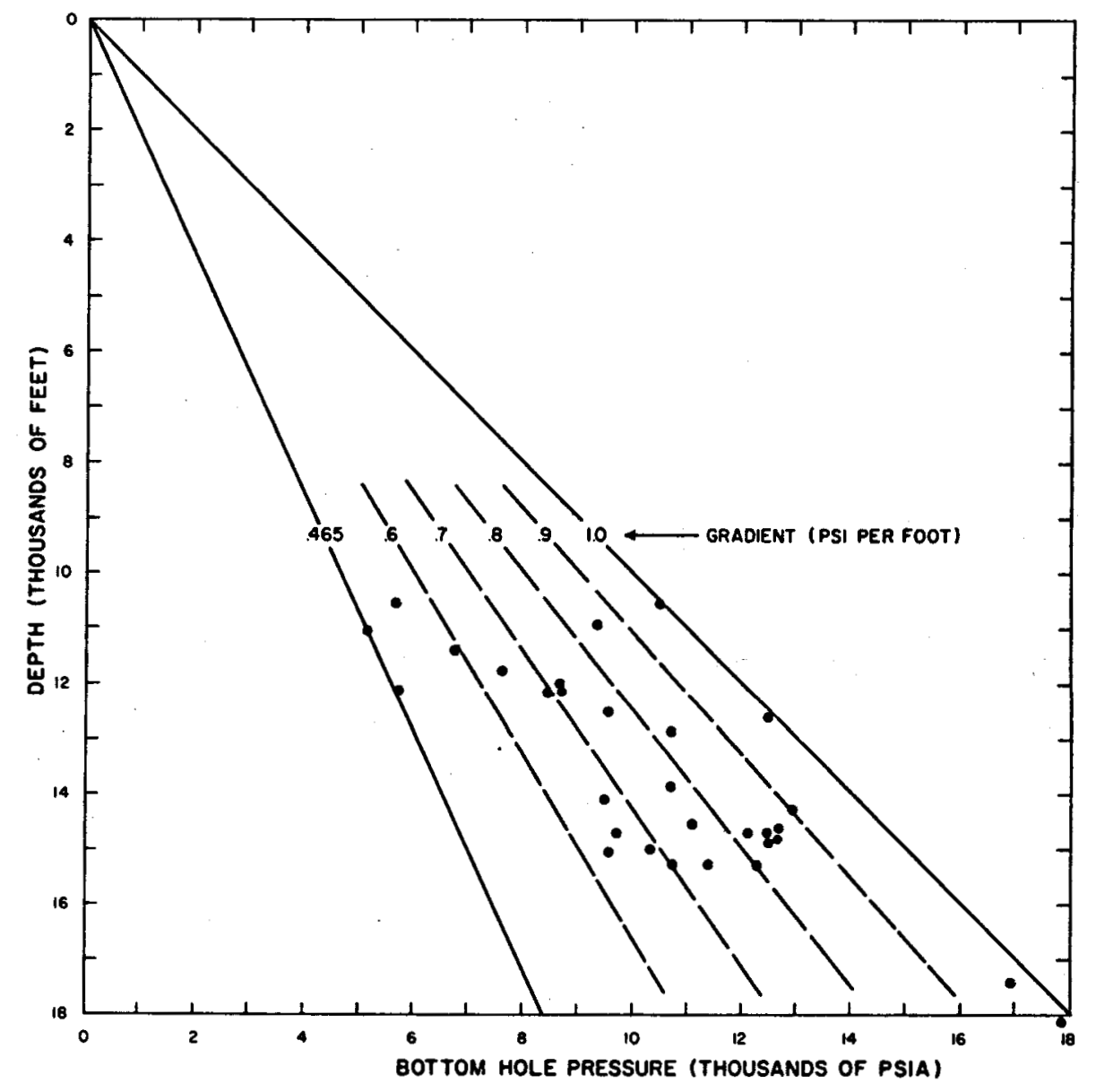

Figure 85. Static bottom-hole pressures versus depth for a number of wells, Chocolate Bayou field, Brazoria County, Texas. 


\section{Reservoir Pressure Decline and Hydrocarbon Production Histories}

Deliverability of hydrocarbons is typically high during the early life of geopressured reservoirs, but drops sharply as reservoir pressures decline.

Pressure decline and hydrocarbon production behavior of geopressured reservoirs in the Gulf Coast area are dependent upon many complex interacting factors. These factors include intrinsic physical properties of the reservoir rock, geological environment, location of faults, dynamic driving forces acting on fluids, well completion techniques, economics, and management policy. The list could be expanded to include virtually every phase of petroleum technology. Here, it is sufficient to state that the behavior of each reservoir is generally unique and unpredictable. Normal trends of well performance, however, can be predicted for gas-condensate production from geopressured reservoirs. Typically, deliverability is high during the early life of these wells, then drops sharply when semi-steady-state conditions are achieved. Deliverability is reduced greatly over the life of the wells as reservoir pressures decline, although many wells are still producing after 10 or 12 years.

Most wells that were drilled in Brazoria County produced gas and condensate; $a$ few produced oil; and, of course, many wells turned out to be dry holes as far as hydrocarbon production was concerned.

Pressure decline and production curves for several wells are discussed below. Wells were selected to illustrate the diverse behavior of reservoirs near the Austin Bayou Prospect (fig. 86).

The Phillips No. 1 Gardiner, South Chocolate Bayou field, Brazoria County, Texas-This well was drilled in 1964 to a total depth of 13,500 feet and produced gas and oil from a 14-foot interval $(11,772$ to 11,786 feet) in the lower Weiting sandstone. Early history of the well is marked by a rapid decline in bottom-hole pressure trom 7,589 to 4,823 psia in less than 12 months (fig. 87). Original geopressure gradient ( $0.644 \mathrm{psi} / \mathrm{foot}) \mathrm{de}$ clined to the hydropressure gradient level $(0.465 \mathrm{psi} / \mathrm{foot})$ in less than 10 months. Initial bottom-hole temperature of $260^{\circ} \mathrm{F}$ declined somewhat for the first few months, then increased to a maximum value of $263^{\circ} \mathrm{F}$ before declining gradually back to $260^{\circ} \mathrm{F}$ after a period of 28 months.
Annual gas and oil production peaked during the early life of the well at $1,644 \mathrm{MMCF}$ (million cubic feet) and 167,000 barrels, respectively (fig. 88). The well produced for only four months in 1964; hence, low production values are recorded for that year. After 16 months the annual gas and oil production declined to $33 \mathrm{MMCF}$ and 91,700 barrels, respectively. At this point the well was reclassified from a gas well to an oil well by the Texas Railroad Commission. Thereafter, production from the well was recorded as casinghead gas and oil. Currently, after 12 years, the well is producing at an annual rate of about 20 MMCF of casinghead gas and 2,250 barrels of oil.

The Phillips No. 1 Houston "JJ," South Chocolate Bayou field, Brazoria County, Texas-This well was drilled to a total depth of 17,020 feet and was completed as a gas producer in 1965. Production was from the "S" sandstone through perforations in the depth interval of 15,187 to 15,332 feet. Bottom-hole temperature was $321^{\circ} \mathrm{F}$ at 15,244 feet. Bottom-hole pressure at a depth of 15,244 feet decreased from the initial 11,375 psia to 5,599 psia during the first year (fig. 89). Four-and-one-half years later the well was producing 95 percent salt water and the bottom-hole pressure was 4,272 psia. Initial geopressure gradient of $0.746 \mathrm{psi} /$ foot declined to the hydropressure gradient level $(0.465 \mathrm{psi} / \mathrm{foot})$ in a period of 6 months and reached a value of $0.28 \mathrm{psi} /$ foot when the well went to salt water. At this point (1970) the well was recompleted into the lower Weiting sandstone and produced gas and condensate from perforations in the depth interval of 14,613 to 14,741 feet (fig. 90 ).

Initial gas and condensate production from the " $S$ " sandstone was 2,259 MMCF and 32,523 barrels, respectively, during 1965. In 1967, the well produced 290 MMCF of gas and 173 barrels of condensate. Production increased again before the well went to salt water in 1970 (fig. 90). Production from the lower Weiting sandstone continued for three years until the well died in 1973 and was plugged and abandoned in 1974. 
The Phillips No. 1 Houston "FF", South Chocolate Bayou field, Brazoria County, Texas-The No. 1 Houston "FF" was drilled to a total depth of 17,201 feet; the well was completed in 1964. The Patrick sandstone was tested in the depth interval 16,776 to 16,870 feet. Bottom-hole temperature was $338^{\circ} \mathrm{F}$ and bottom-hole pressure was 10,095 psia at a depth of 16,700 feet. Apparently the production test was unsuccessful since no production from the Patrick sandstone was recorded.

Initial production was from the " $S$ " sandstone from the depth interval of 15,238 to 15,386 feet. Reservoir temperature was $318^{\circ} \mathrm{F}$ and the 24 -hour shut-in pressure was 12,273 psia at a depth of 15,293 feet. A few weeks later the temperature was $326^{\circ} \mathrm{F}$ when measured at a depth of 15,312 feet after a shut-in period of 48 hours. Thereafter, temperature decreased over a period of several months and stabilized and remained constant at $322^{\circ} \mathrm{F}$ for several years (fig. 91).

Bottom-hole pressures measured at a depth of 15,293 feet in the " $S$ " sandstone declined in a period of about 17 months from 12,273 psia in August 1964 to 5,215 psia in January 1966 (fig. 91). At that time much of the driving force provided by gas compressibility had been expended; thereafter, pressures declined at a much slower rate and finally stabilized at about 3,000 psia from 1971 to 1973.

Maximum annual gas production from the " $S$ " sandstone was 2,342 MMCF in 1965 and declined to about 66 MMCF in 1973. Production from this well was increased dramatically in 1974 by perforating the sandstone interval from 13,788 to 13,824 feet (fig. 92). In 1976, production was down again and the Banfield sandstone (depth unspecified) was perforated in an effort to increase production.

A plot of bottom-hole pressures, corrected for gas compressibility $Z$, versus cumulative production from the " $S$ " sandstone, fails to give a straight-line relationship (fig. 93). Volume of original gas in place G can be calculated when a linear relationship exists, but in this case, $G$ is estimated by extrapolation of the curve to a zero value of $\mathrm{P} / \mathrm{Z}$.

The General Crude Oil Co., No. 3 Houston Farms Dev. Co., South Chocolate Bayou field, Brazoria County, Texas-This well was completed in December 1960 to a total depth of 13,472 feet and produced gas and condensate from the 8-foot-thick Frio " $P$ " sandstone in the depth interval 12,510 to 12,518 feet. Production did not commence until July 1964 (fig. 94). In 1965, the annual production was 791 MMCF of gas and 35,728 barrels of condensate. Production decline curves are not as steep as most of the wells described previously and are also relatively free of rapid fluctuations over the 12 years of production history. The well was still producing in 1976 at annual rates of about $122 \mathrm{MMCF}$ of gas and 1,350 barrels of condensate. Bottom-hole pressure and temperature values of $9,087 \mathrm{psi}$ and $275^{\circ} \mathrm{F}$, respectively, were recorded in 1961 at a depth of 12,505 feet. In summary, this thin sandstone produced over 5 billion cubic feet of gas and about 190,000 barrels of condensate over a period of $12 \frac{1}{2}$ years.

The Phillips No. 2 Houston " $M$," Chocolate Bayou field, Brazoria County, Texas-The Houston " $M$ "' No. 2 had a relatively weak production history caused partly by the close proximity of a fault which restricted the area of drainage. The well was completed in September 1956 and produced gas and condensate from the Rycade sandstone between depths of 11,396 and 11,404 feet. Production curves and well-log responses through the production zone are shown in figure 95. After producing for $7 \frac{1}{3}$ years the well was shut in during 1964 and plugged in 1965. 


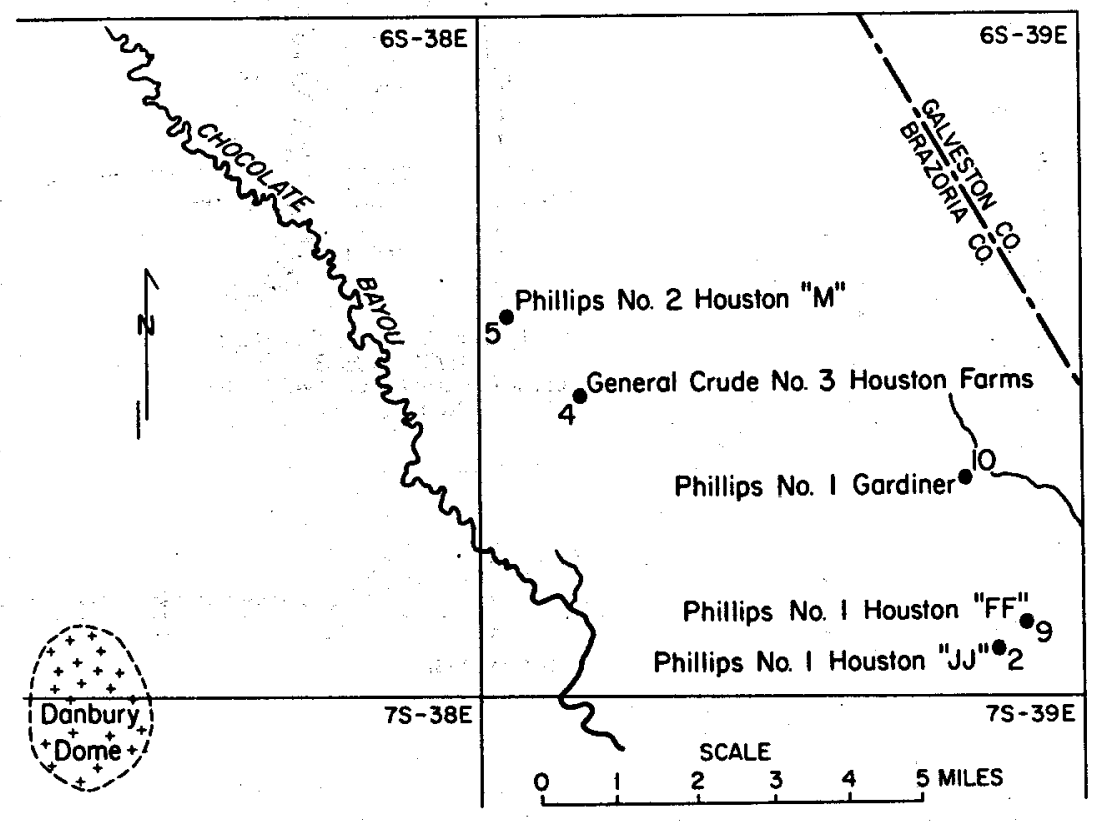

Figure 86. Location of wells, Chocolate Bayou field, selected to illustrate pressure decline and production behavior of reservoirs near Austin Bayou Prospect.

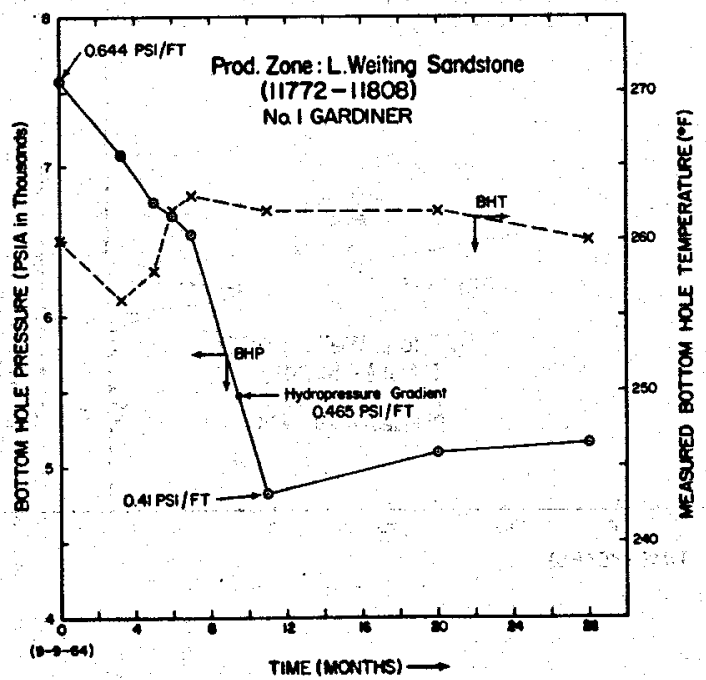

Figure 87. Early history of bottom-hole pressures and temperatures in Phillips No. 1 Gardiner, Chocolate Bayou field, Brazoria County, Texas. 


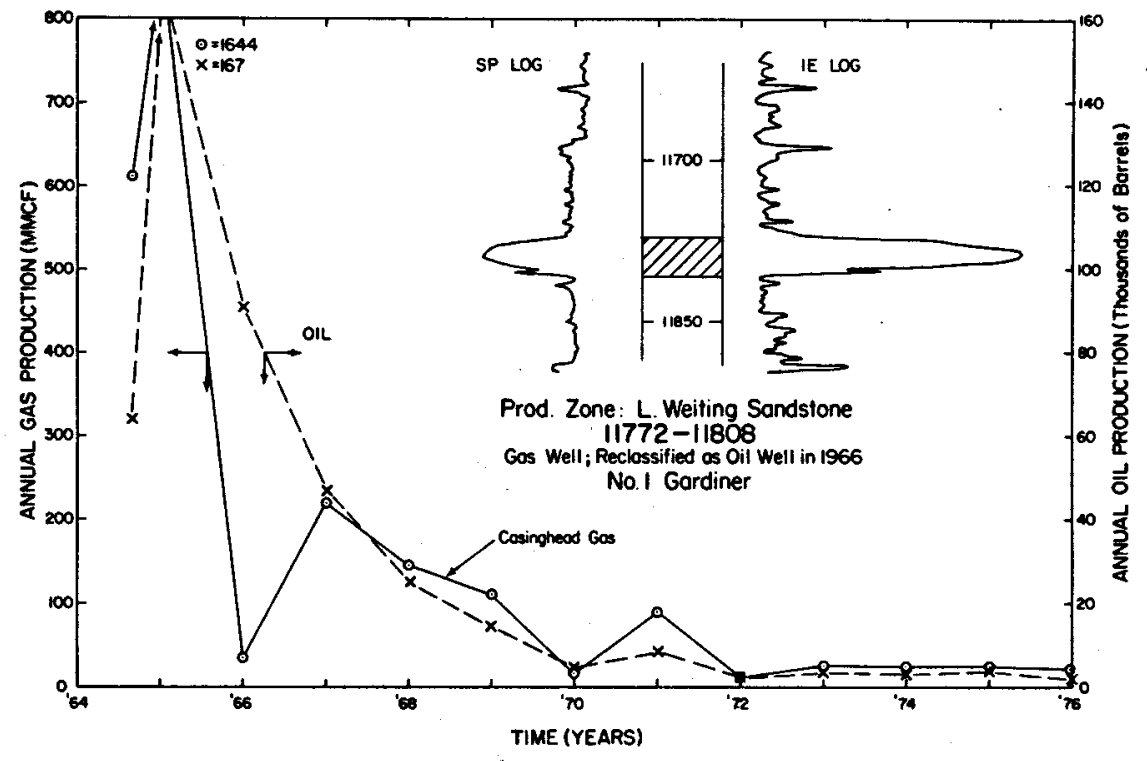

Figure 88. Production history of Phillips No. 1 Gardiner, Chocolate Bayou field, Brazoria County, Texas.

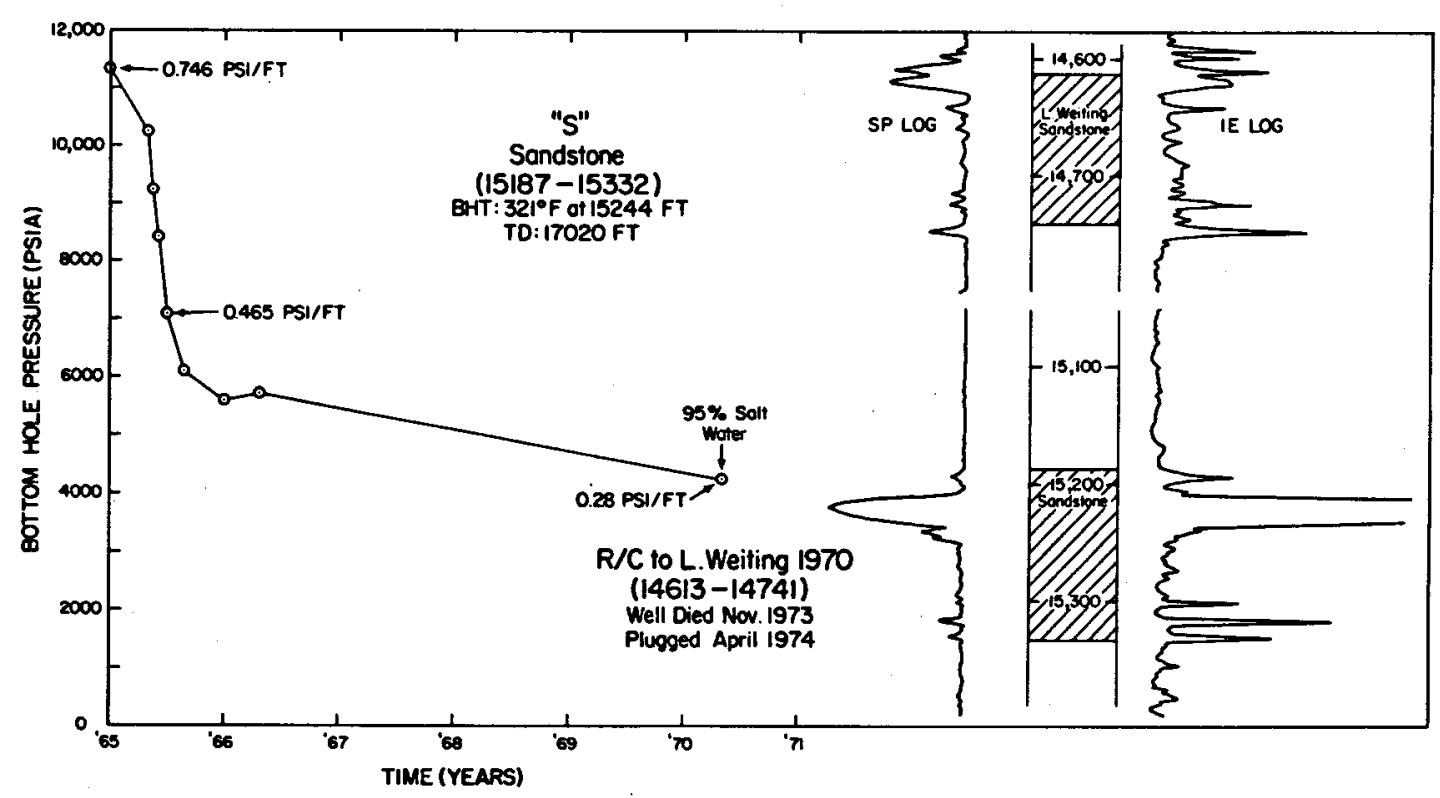

Figure 89. History of decline in bottom-hole pressure for No. 1 Houston "JJ," Chocolate Bayou field, Brazoria County, Texas. 


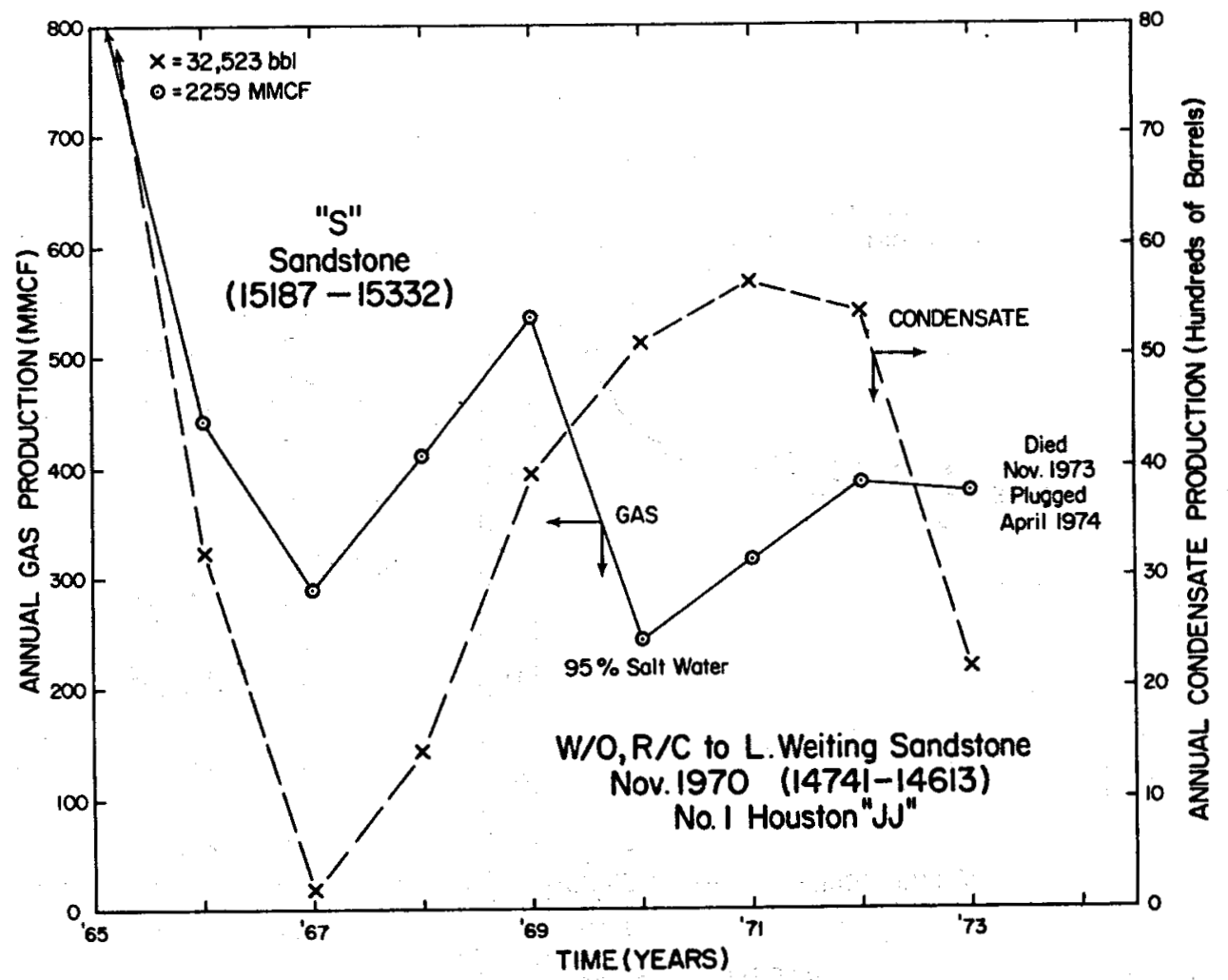

Figure 90. Production history of Phillips No. 1 Houston "JJ," Chocolate Bayou field, Brazoria County, Texas.

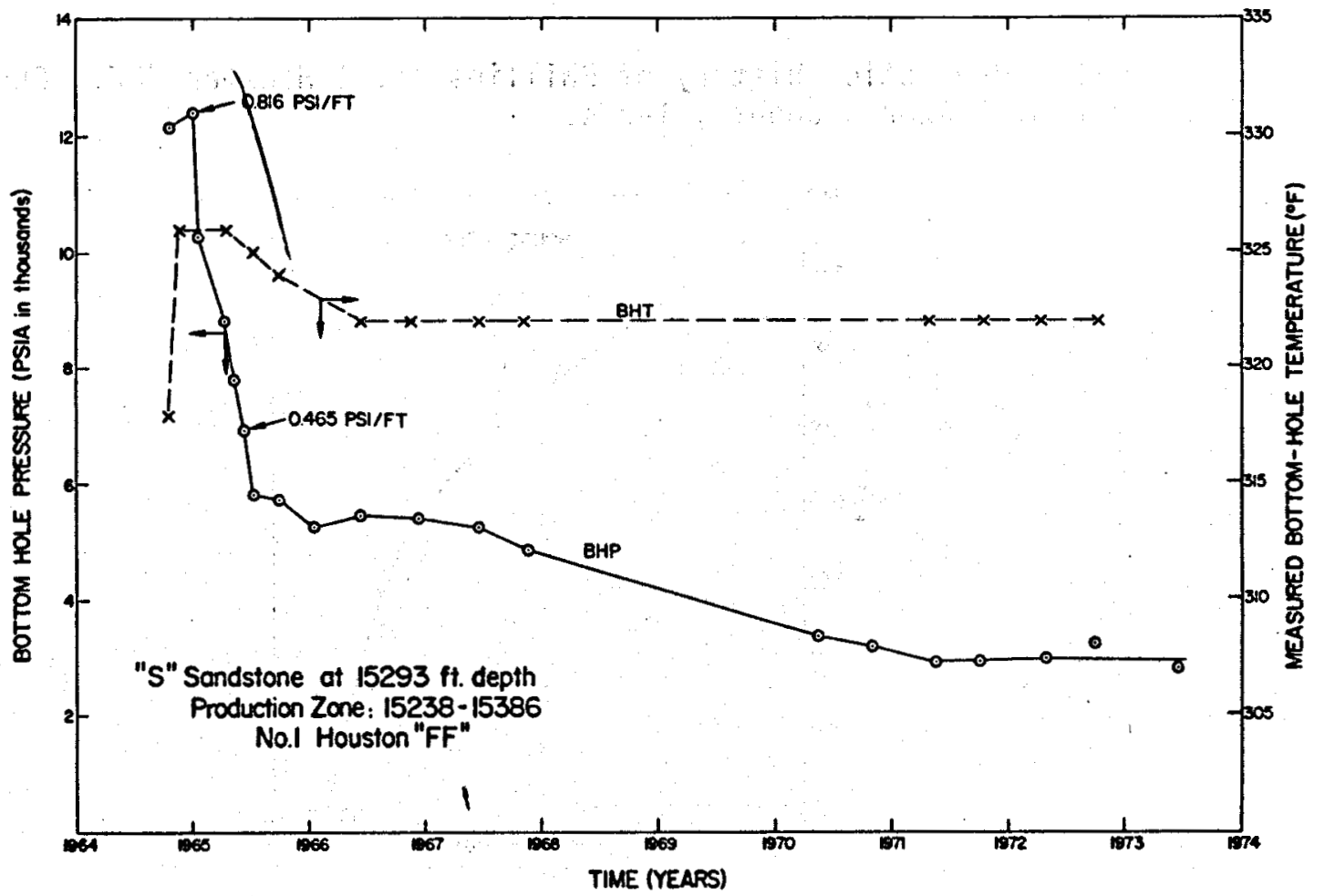

Figure 91. History of decline in bottom-hole pressure and temperature for Phillips No. 1 Houston "FF," Chocolate Bayou field, Brazoria County, Texas. 

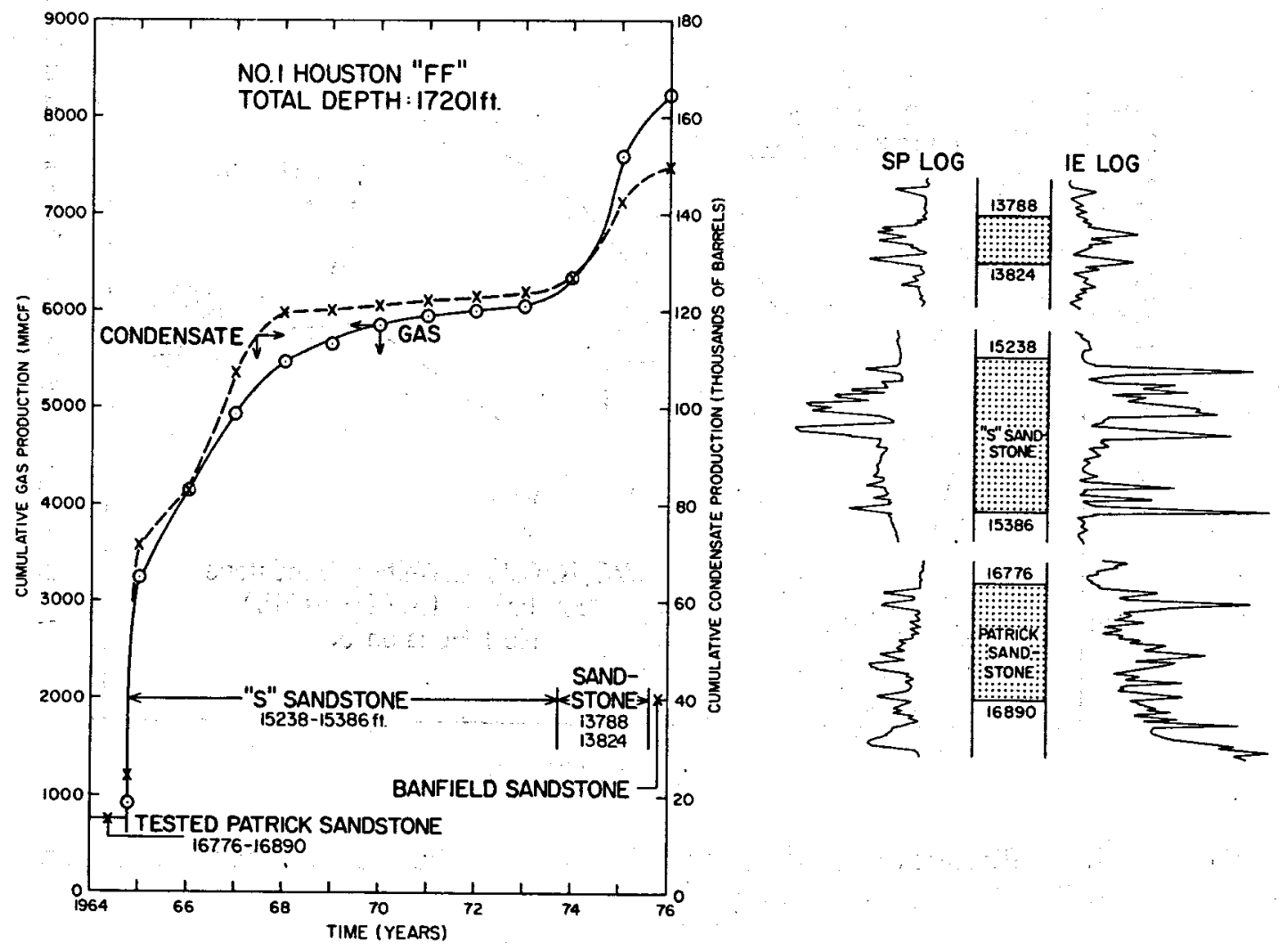

Figure 92. Production history of Phillips No. 1 Houston "FF," Chocolate Bayou field, Brazoria County, Texas.

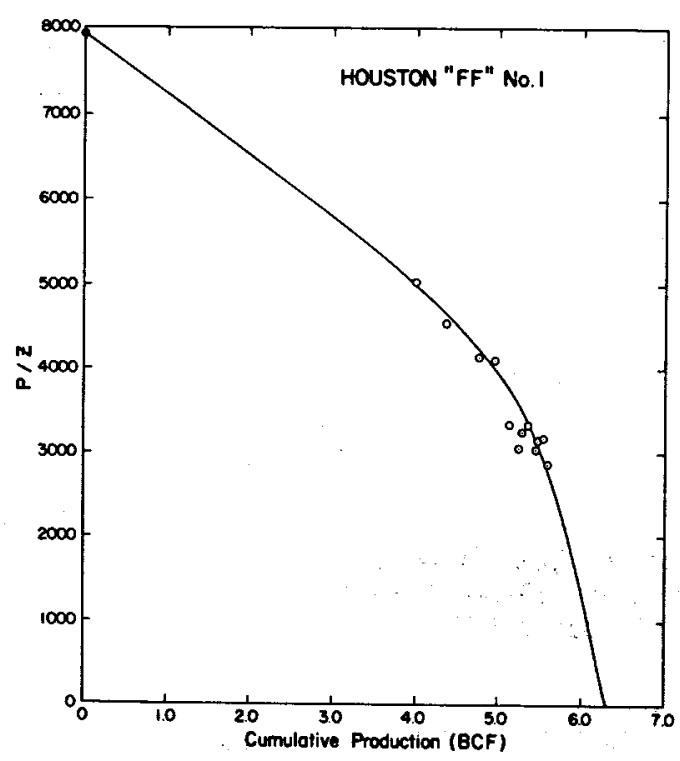

Figure 93. $P / Z$ versus cumulative production from the " $S$ " sandstone, Phillips No. 1 Houston "FF," Chocolate Bayou field, Brazoria County, Texas (Farina, 1976). 


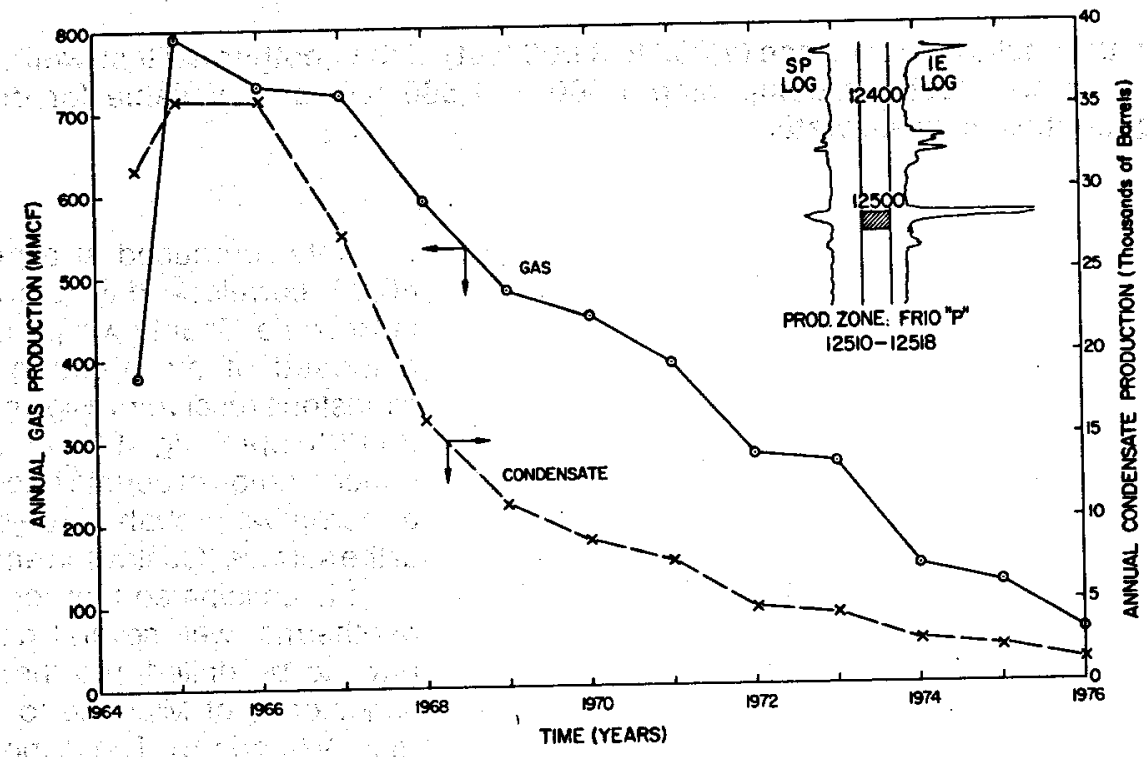

Figure 94. Production history of Phillips No. 3 Houston Farms Development Company, Chocolate Bayou field, Brazoria County, Texas.

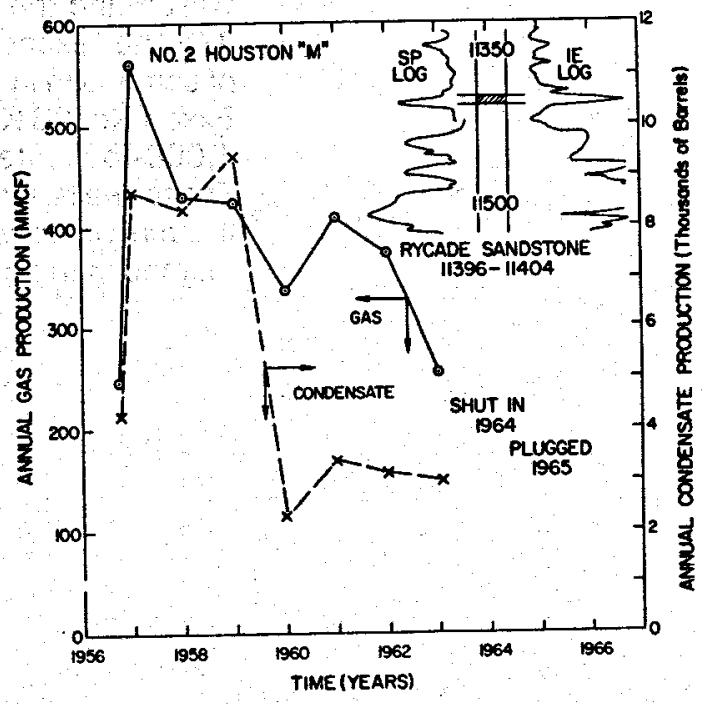

Figure 95. Production history of Phillips No. 2 Houston "M," Chocolate Bayou field, Brazoria County, Texas. 


\section{Disposal of Geothermal Waste Water}

In the shallow subsurface $(2,000$ to 3,000 feet $)$ of the geothermal test-well site area, porous sandstone sections comprising 1,300 to 1,500 feet are available for disposal of huge quantities of waste water.

Water produced at a rate of 20,000 to 40,000 barrels per day from a geothermal well in Brazoria County will probably have to be disposed of by injection into shallower sandstone reservoirs. High salinity $(40,000$ to $85,000 \mathrm{ppm}$, fig. 96) and possible high concentration of certain trace elements, such as boron, will probably prohibit water disposal at the surface (Gustavson and Kreitler, 1976).

It is anticipated that for each producing geothermal well several disposal wells will have to be drilled into the shallower, thick sandstones of Miocene to Pleistocene age (figs. 97 and 98). The disposal interval must be located beneath the deepest freshwater zones and above the shallowest oil and gas zones. Thus, in the area of the test well site (fig. 97) the disposal interval will be between the depths of 2,000 and 7,000 feet (fig: 98 ). From existing well control, it is estimated that in this 5,000-foot interval there will be 1,500 to 1,800 feet of sandstone suitable for injection of the geothermal water.

Two saltwater disposal wells occur in the area of the test well site, the Texaco No. 3B Wilson and the Exxon No. 2B Korenek (fig. 97). The Texaco No. 3BWilson has 1,300 feet of sandstone in a 3,500-foot interval, and the Exxon No. 2B Korenek has 1,500 feet over a 4,000-foot interval in the injection zone. These wells indicate that disposal of geothermal waste water by injection is a plausible method in the geothermal test well site area. 


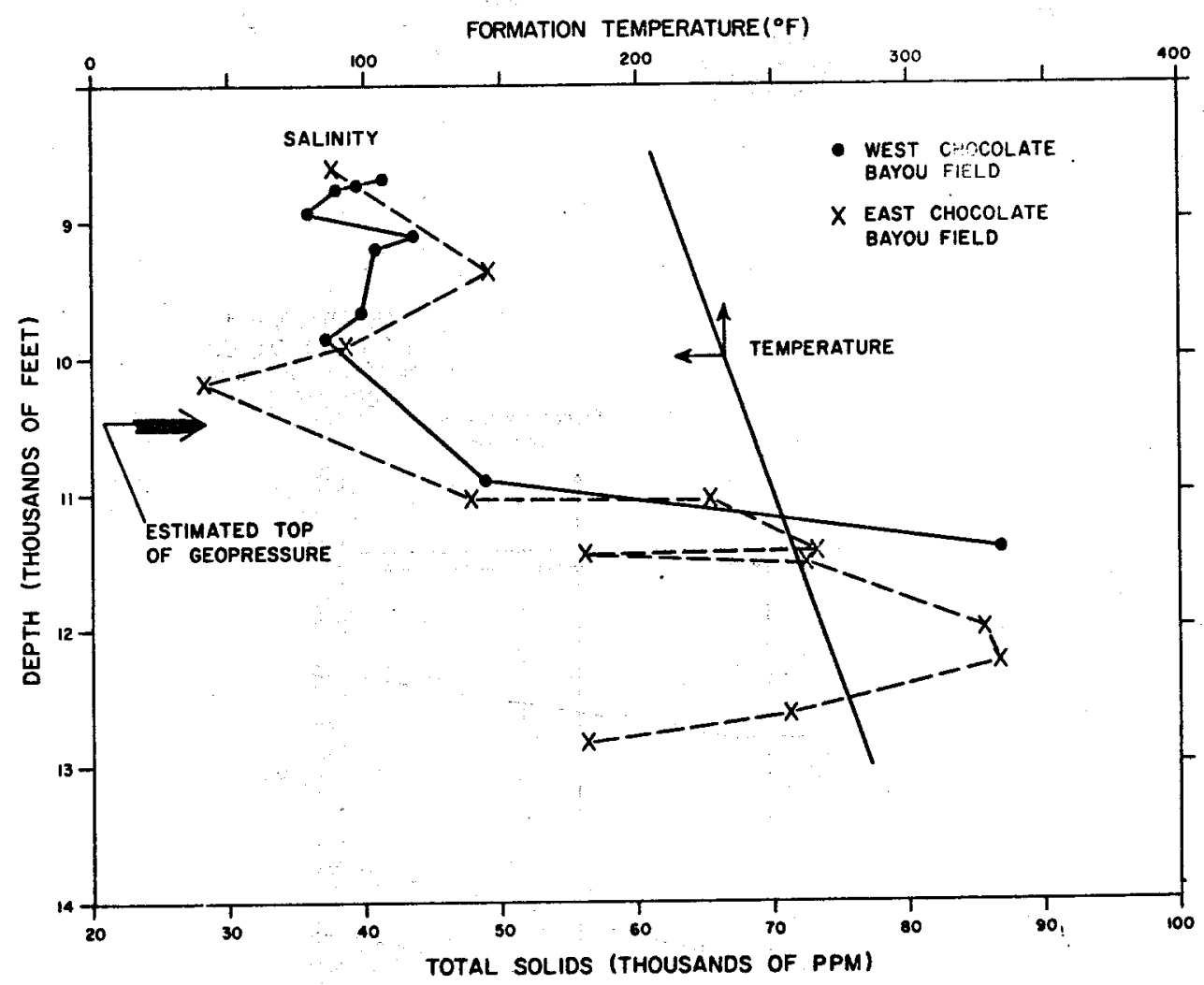

Figure 96. Salinity and temperature of formation waters, Chocolate Bayou field, Brazoria County, Texas.

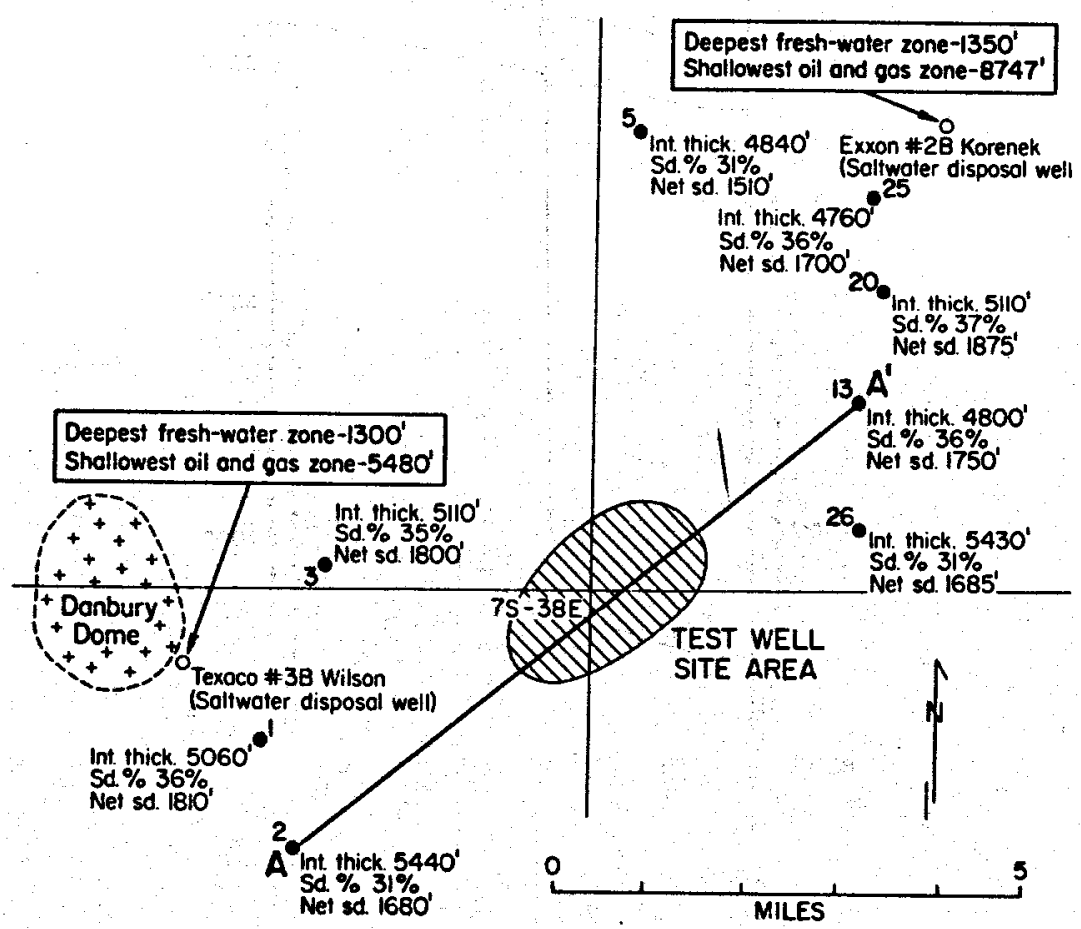

Figure 97. Thickness of sandstone suitable for disposal of geothermal waste water in shallow subsurface near proposed test well site, and location of section $A A^{\prime}$ shown on figure 98 . 
A

HUMBLE

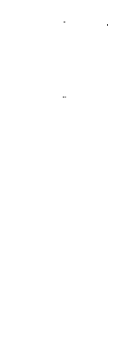

7S-38E-2

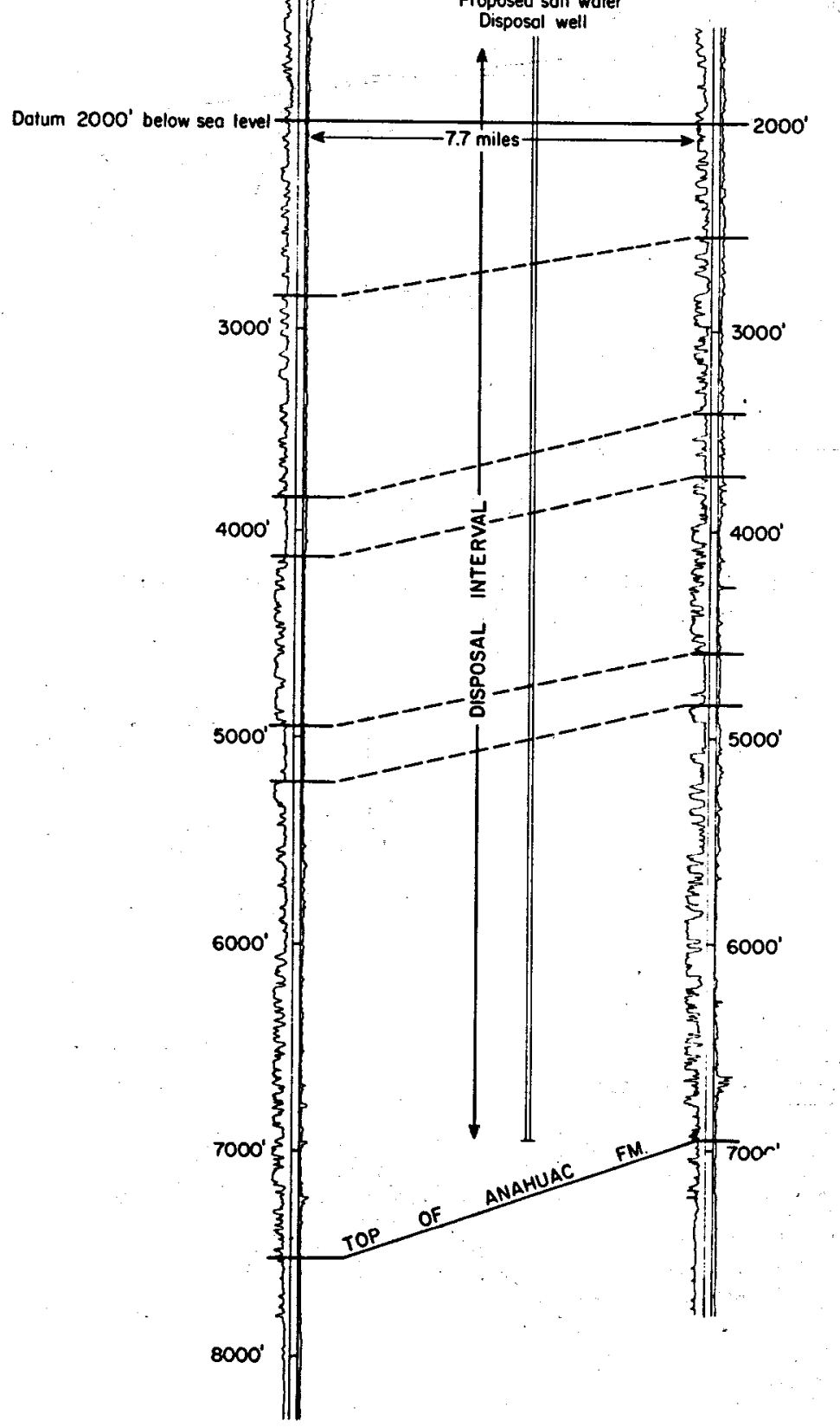

TEXAS CO. and

FT. BEND OIL CO.

No. 2 Houston Forms

$6 S-39 E-8$ 


\section{Predicted Reservoir Performance}

More than 10 billion barrels of water in place in the prospective sandstone reservoirs of the Austin Bayou Prospect contain potential electrical energy of 1,733 $\mathrm{MW}-\mathrm{yr}$ and $\mathbf{4 0 0}$ billion cubic feet of methane in solution.

Geological analysis indicates that the proposed test well in the Austin Bayou Prospect will drain many sandstone units in an area of approximately 16 square miles: The thickness of these sandstones is 840 feet and is the sum of all sandstone units indicated by the interpolated spontaneous-potential $\log$ of the test well for zones $A, B, C, D, E$, and $F$ (fig. 99). An average porosity of 20 percent or more is predicted for 250 feet of the total sandstone; the remaining 560 feet has a porosity that varies between 5 and 20 percent and averages 15 percent. The total bulk volume of all of the sandstone units is 360 billion cubic feet, and the total pore volume is 60 billion cubic feet. Provided that all pore space is filled with water, the aquifer will contain more than 10 billion barrels of water; if the water contains 40 cubic feet of methane per barrel, as illustrated earlier, then the total gas resource should be 426 billion cubic feet in place.

House, Johnson, and Towse (1975) estimate the potential electrical energy of deep $(16,000$ feet) geopressured geothermal reservoirs at $300^{\circ} \mathrm{F}$ to be $49.1 \times 10^{-11} \mathrm{MW}$-yr per pound of reservoir water in place. Based on this estimate, the total electrical energy potential of water contained by reservoirs in the Austin Bayou Prospect is 1,733 MW-yr. To obtain the available electrical energy, the in-place potential must be multiplied by a recovery factor, which is the traction of in-place water that can be produced at the surface. The recovery factor depends on a number of variables, such as reservoir driving forces, rock and fluid compressibilities, shale water influx, changes in reservoir characteristics as a function of pressure decline, effects of free gas and gas in solution, production rate, production method, and possible reinjection of produced water into the producing formations. Many of these variables can be evaluated only after appropriate production tests are made and adequate depletion history is available.

Simulation studies of geopressured reservoirs have been conducted by Garg, Pritchett, Rice, and Riney (1977). They have concluded that without reinjection only 10 percent of the in-place methane will be produced (fig. 100). The total flow rate and methane flow rate will decrease rapidly by this method (figs. 101 and 102), but there will be little decline in the fluid temperature (fig. 103).

On the other hand, if a substantial portion of the water is reinjected into the producing reservoir to maintain reservoir pressure and fluid flow rates, more than 90 percent of the gas can be extracted. By using the reinjection method, higher reservoir pressure and total fluid flow rates can be maintained for a longer period of time. Total fluid flow rate will increase slightly after 20 years (fig. 101), but the methane flow rate will continue to decline as a result of dilution by injected water (fig. 102). The reservoir simulation model of Garg and others predicts that fluid temperatures will remain relatively constant at approximately $300^{\circ} \mathrm{F}$ for 15 to 20 years with reinjection and will then decline to less than $200^{\circ} \mathrm{F}$ after 55 years (fig. 103). The surface water in excess of that which can be reinjected is estimated to peak after 8 years of production at 94 million barrels per well pair (fig. 104). The amount of excess water declines to a break-even point in 39 years, after which time there will be a water deficit.

The relationship between the water flow rate and sandstone thickness (fig. 105) for the test well (fig. 99) has been computed from equation (7), given 5 to 25 millidarcys permeability and a constant drawdown pressure of 1,000 psi. Other values for the equation are:

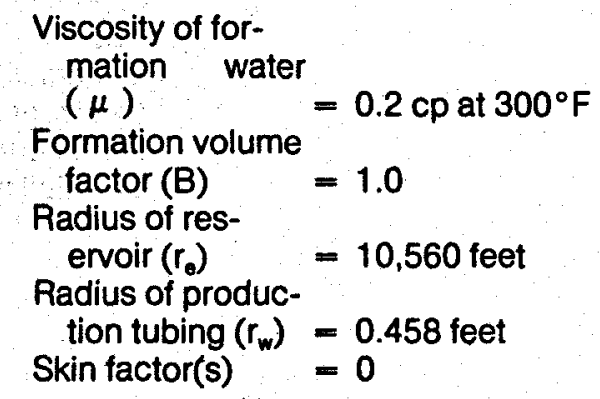

If all the sandstone units in the test well (840 feet) are perforated, adequate flow rate is possible with permeability as low as 5 millidarcys and a drawdown pressure of 1,000 psi (fig. 105). If the drawdown pressure is doubled, the flow rate is also doubled, with 
the other parameters remaining constant. If the permeability of any sandstone unit or zone is known, then the flow rate can be determined from figure 105. For example, if the 230 feet of sandstone in zone E were produced at a drawdown pressure of 1,000 psi and assumed permeability of 15 millidarcys, 13,140 barrels per day would be produced.

Dewatering of shales may have a significant influence on the maintenance of reservoir pressure while zone $E$ is produced. Pressure decline curves based on a reservoir simulation model (Knapp and Elemo, personal communication) show that the bottom-hole flowing pressure will decrease by 2,138 psi in 20 years when only the sandstone compressibility is taken into account (fig. 106). However, the pressure will decrease by only 848 psi when the maximum possible shale dewatering effects are added. Reservoir parameters used in the simulation program for zone $E$ are:

\begin{tabular}{|c|c|}
\hline $\begin{array}{l}\text { Single well } \\
\text { drainage area }\end{array}$ & 16 square miles \\
\hline $\begin{array}{l}\text { Depth } \\
\text { Initial bottom- }\end{array}$ & $15,300-15,900$ feet \\
\hline $\begin{array}{l}\text { hole pressure } \\
\text { Bottom-hole draw- } \\
\text { down pressure }\end{array}$ & $10,318 \mathrm{psi}$ \\
\hline Fluid flow rate & $13,140 \mathrm{~B} / \mathrm{D}$ \\
\hline $\begin{array}{l}\text { Water salinity } \\
\text { Temperature }\end{array}$ & $\begin{array}{l}45,000 \mathrm{ppm} \\
325^{\circ} \mathrm{F}\end{array}$ \\
\hline Sandstone & \\
\hline Thickness & 230 feet \\
\hline Porosity & 20 percent \\
\hline $\begin{array}{l}\text { (horizontal) } \\
\text { Matrix com- } \\
\text { pressibility }\end{array}$ & $1.21 \times 10^{-5} \mathrm{psi}^{-1}$ \\
\hline Shale & \\
\hline $\begin{array}{l}\text { Thickness } \\
\text { Porosity } \\
\text { Permeability }\end{array}$ & $\begin{array}{l}310 \text { feet } \\
16.5 \text { percent }\end{array}$ \\
\hline (horizontal) & 0 \\
\hline $\begin{array}{l}\text { Matrix com- } \\
\text { pressibility }\end{array}$ & $2 \times 10^{-5} \cdot \mathrm{psi}^{-1}$ \\
\hline
\end{tabular}




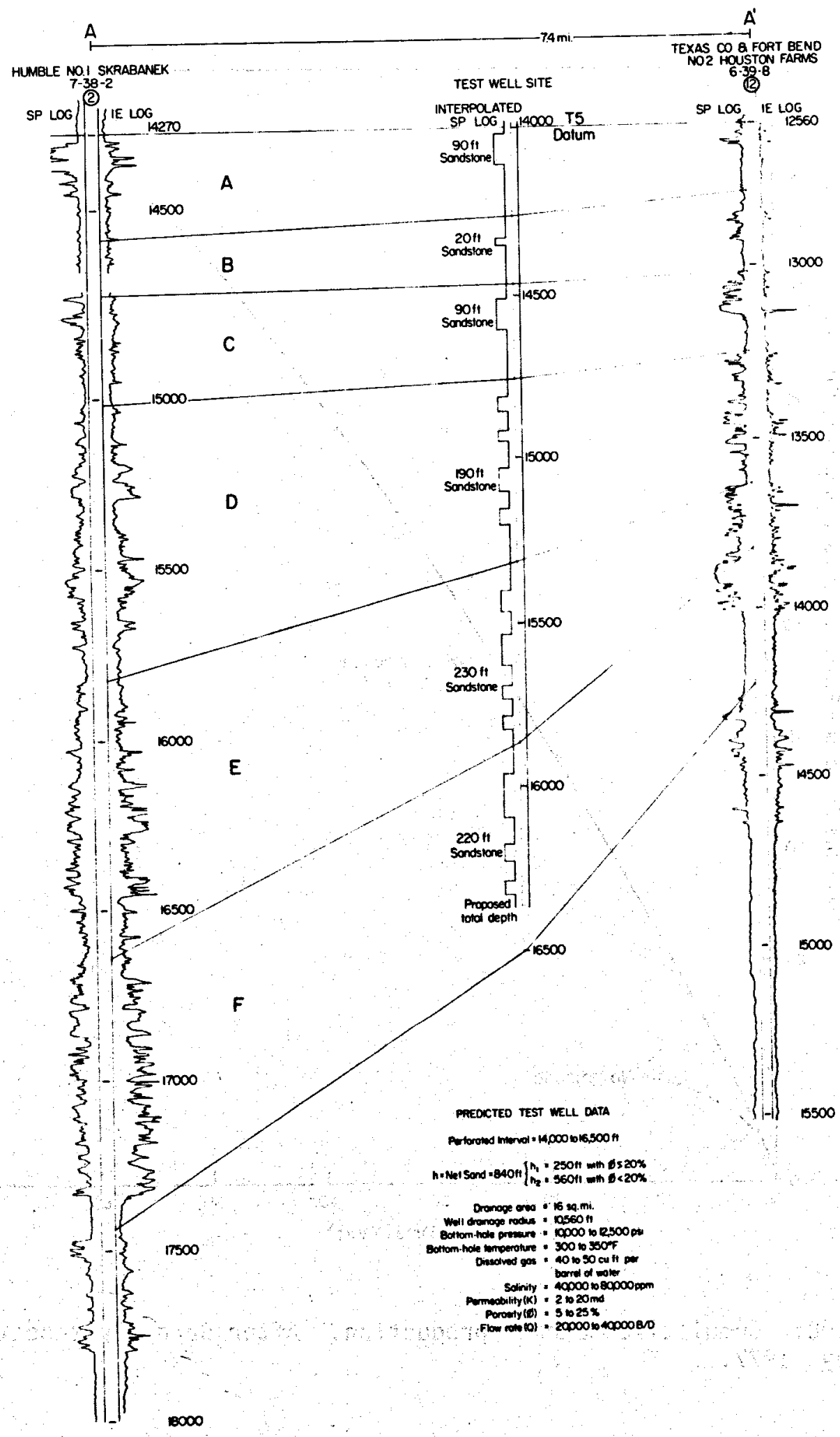

Figure 99. Expected sandstone distribution from an SP log created for the test well site by interpolation from existing control wells. 


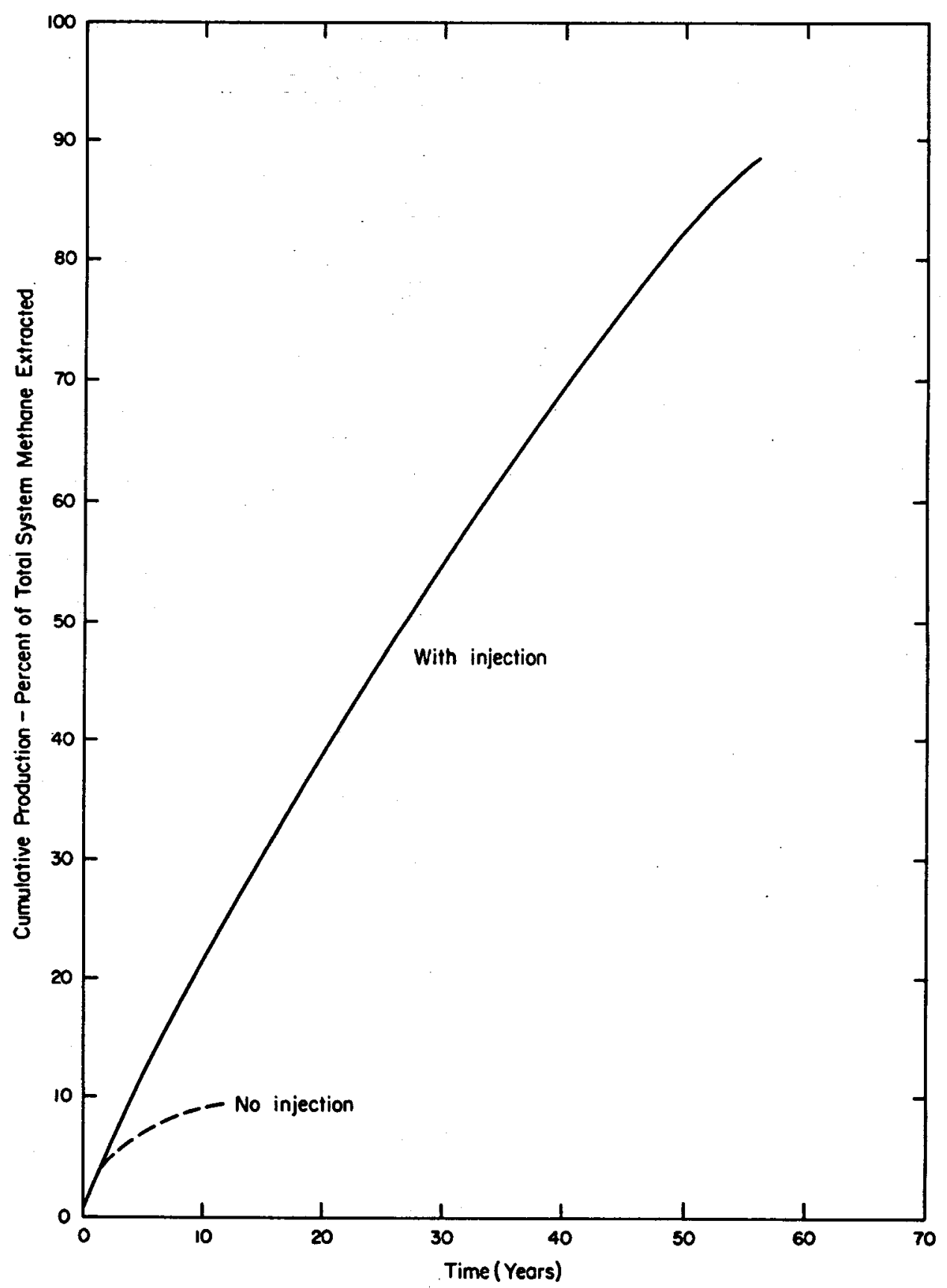

Figure 100. Cumulative methane production. After Garg, Pritchett, Rice, and Riney, 1977. 


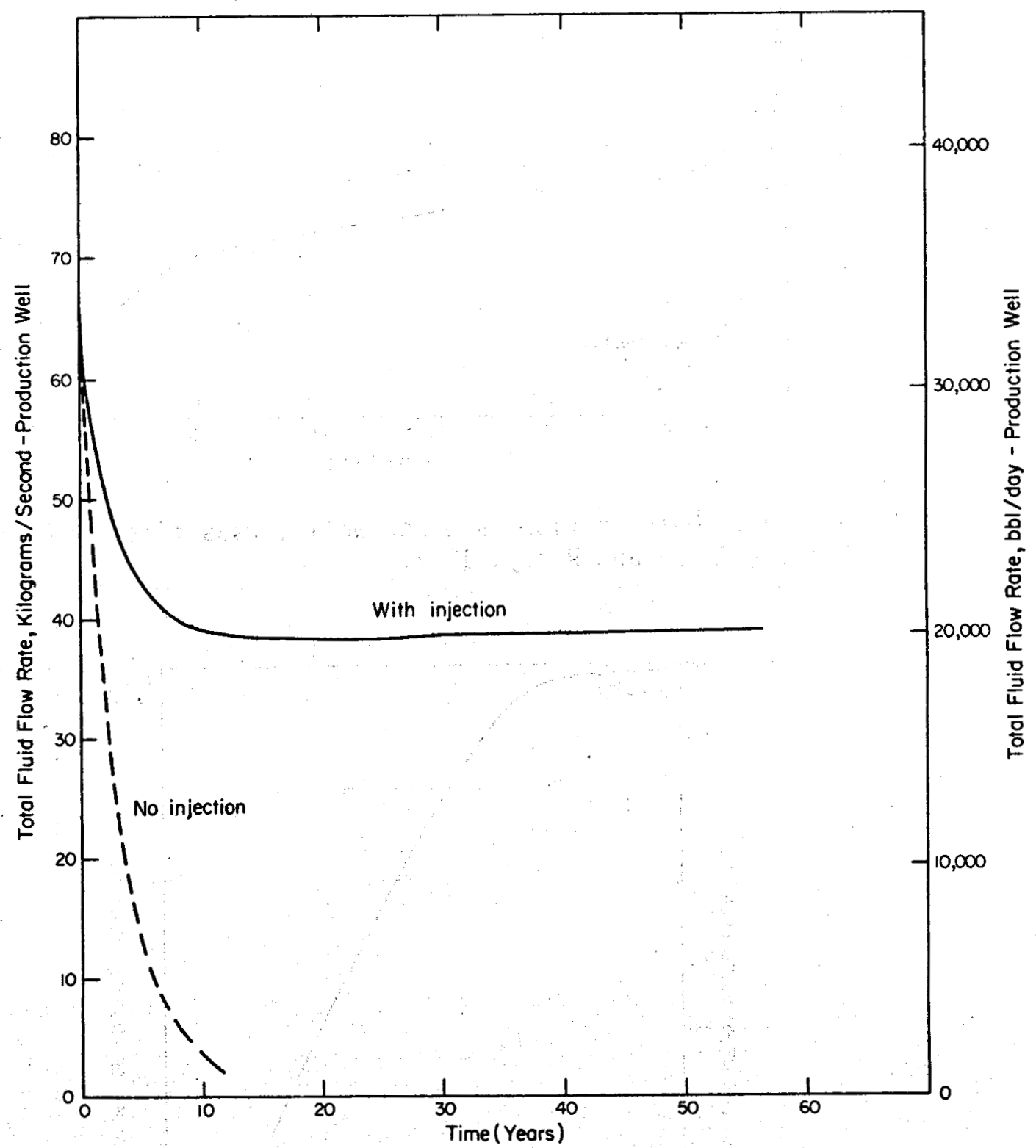

Figure 101. Total flow rate versus time per well (water plus methane). After Garg, Pritchett, Rice, and Riney, 1977. 


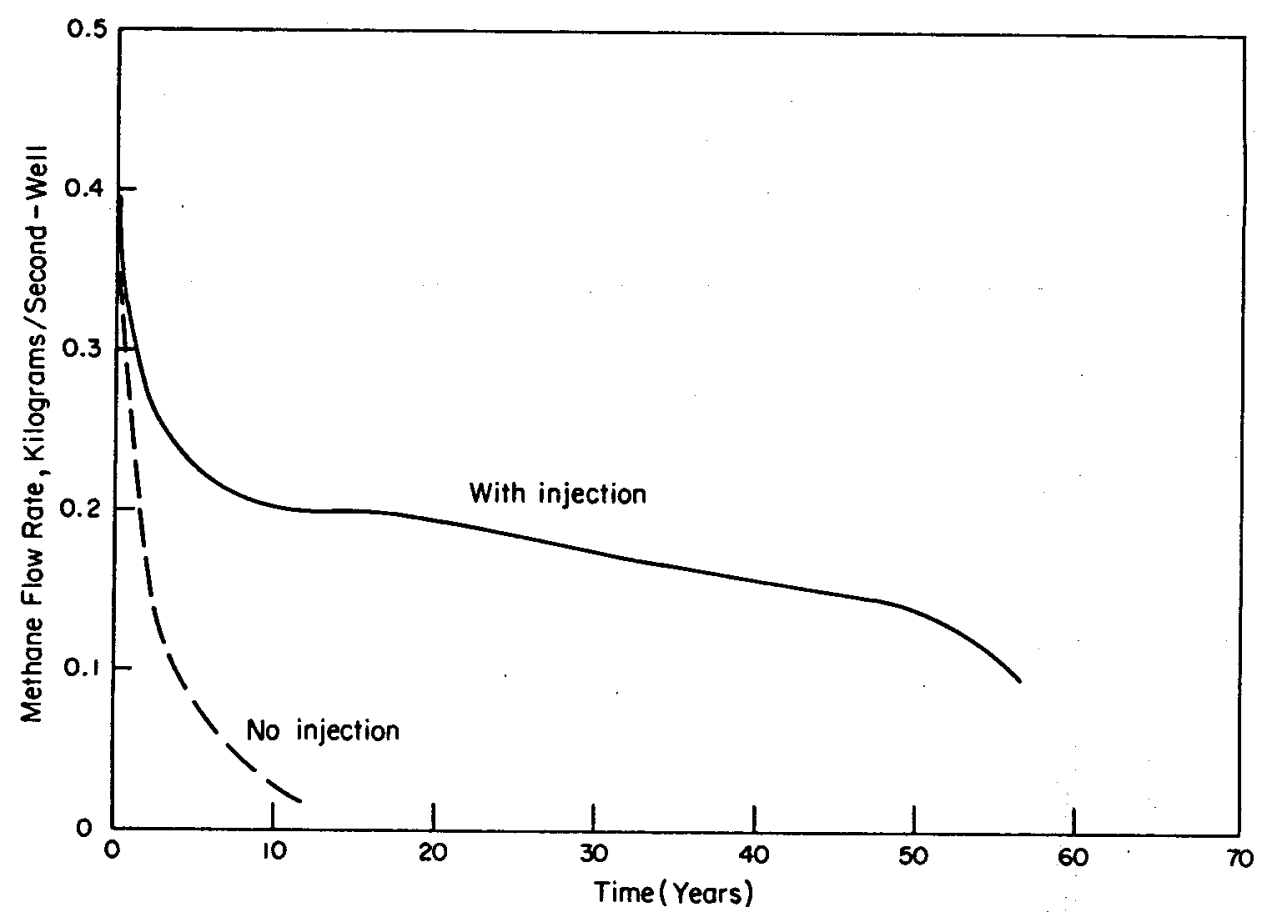

Figure 102. Methane flow rate per well versus time. After Garg, Pritchett, Rice, and Riney, 1977.

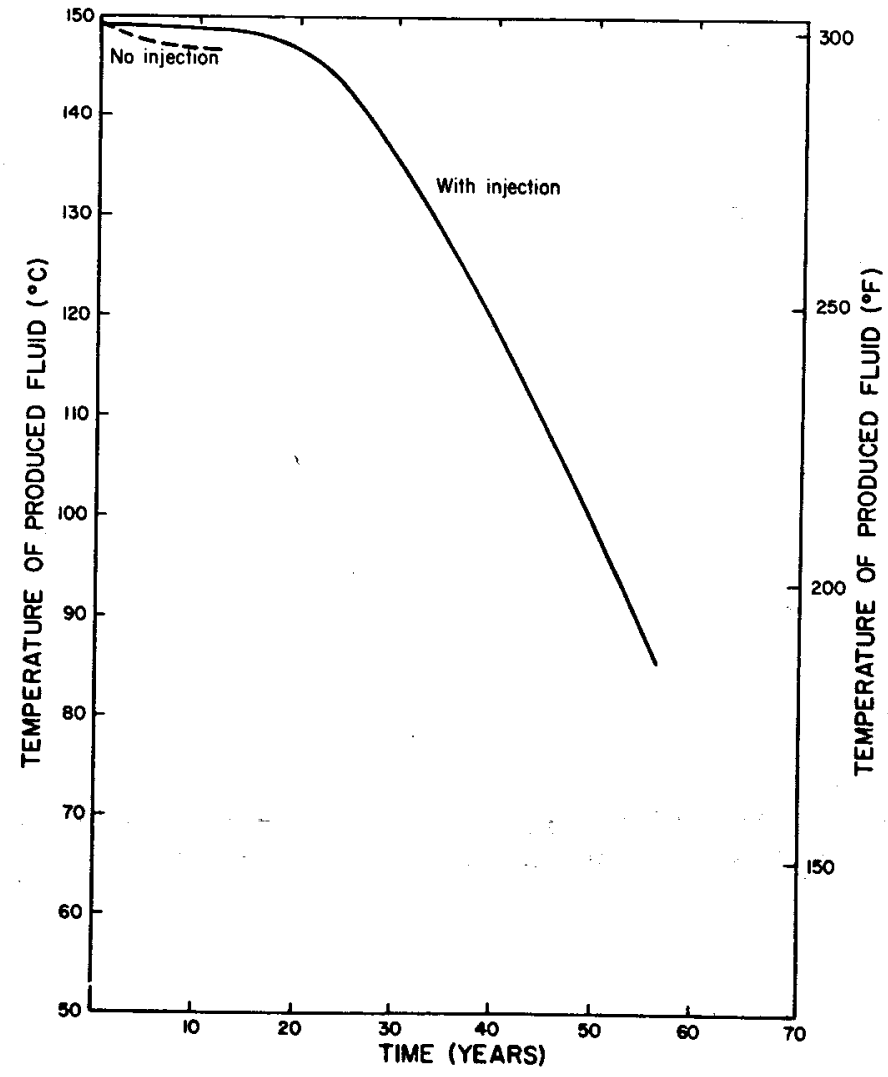

Figure 103. Temperature of produced field. After Garg, Pritchett, Rice, and Riney, 1977. 


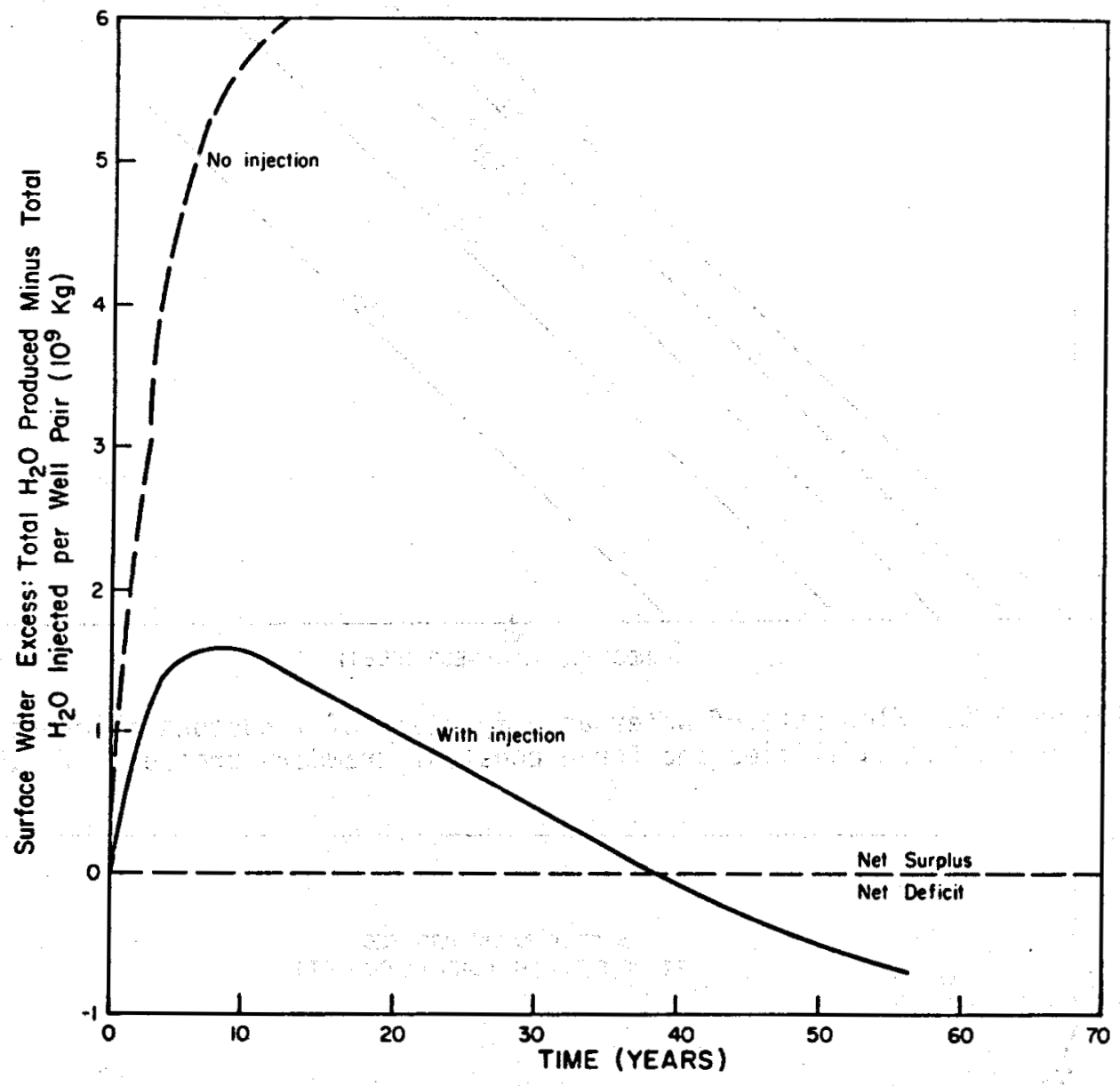

Figure 104. Surface water excess inventory per well pair versus time. After Garg, Pritchett, Rice, and Riney, 1977. 


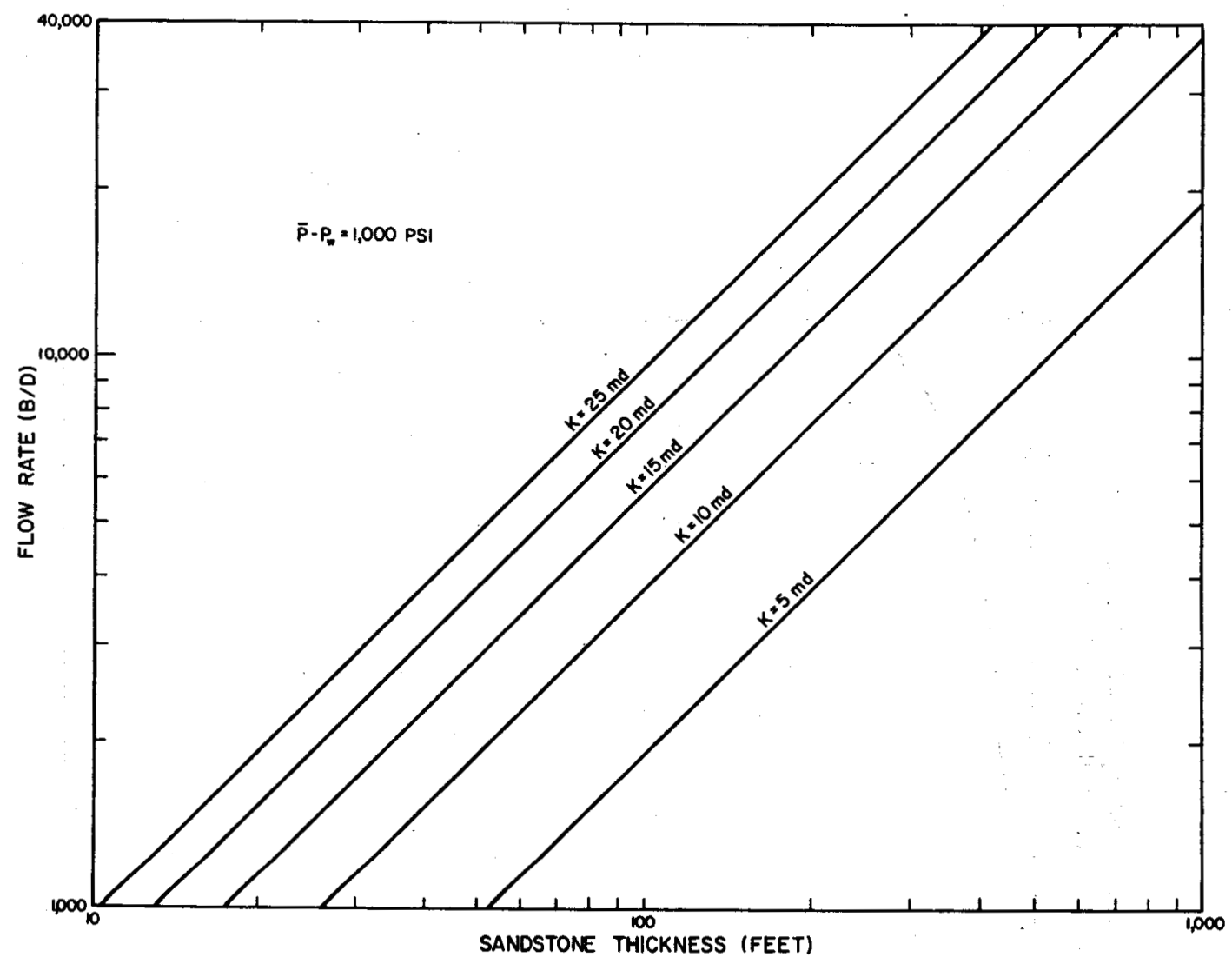

Figure 105. Flow rate of water as a function of sandstone thickness for different permeabilities and for a constant drawdown pressure of 1,000 psi.

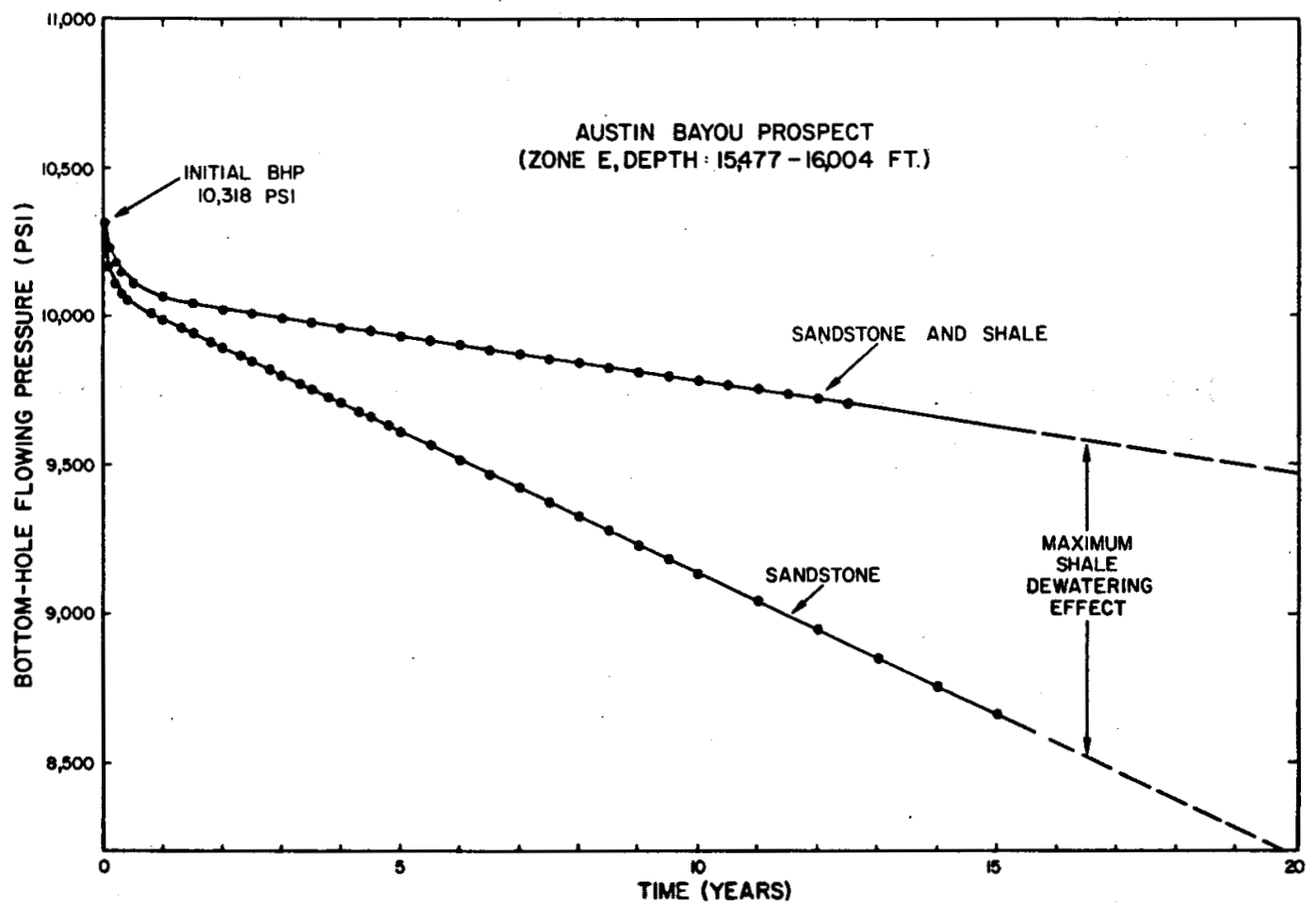

Figure 106. Predicted bottom-hole flowing pressure versus time. After Knapp and Elemo, 1977. 


\section{Acknowledgments}

Many companies have provided various types of subsurface data for this study. These companies are gratefully acknowledged:

\begin{tabular}{|c|c|}
\hline Allied Chemical & McCulloch Oil Corporation \\
\hline Amoco Production & George Mitchell and \\
\hline Company & Associates \\
\hline Atlantic Richfield & Mobil Oil Company \\
\hline Company & Monsanto Chemical \\
\hline Cities Service Company & Company \\
\hline Coastal States Gas & Robert Mosbacher \\
\hline Company & Oleum \\
\hline Cockrell Corporation & Oxy Petroleum, Inc. \\
\hline Continental Oil Company & Pennzoil Producing \\
\hline Dow Chemical, USA & Company \\
\hline Exxon Company, USA & Phillips Petroleum \\
\hline General Crude Oil & Company \\
\hline Company & Shell Oil Company \\
\hline Gulf Oil Company, USA & Tenneco Oil Company \\
\hline Michel T. Halbouty & Texaco, Inc. \\
\hline Houston Oil and Minerals & Texas Eastern \\
\hline Hunt Oil Company & Transmission Corp. \\
\hline & Texas Gas \\
\hline & \\
\hline
\end{tabular}

Sincere appreciation is expressed to the following individuals who provided special assistance:

C. R. Burnette, Tenneco Oil Company

C. W. Dye, General Crude Oil Company

W. A. Fowler, Phillips Petroleum Company

W. E. Galloway, Bureau of Economic Geology

H. L. Johnson, Teledyne Exploration Company

L. G. Kessler II, Phillips Petroleum Company

J. W. Macon, Cartographic Section, Bureau of Economic Geology

R. L. Nicholas, Shell Oil Company

D. C. Ratcliff, Well Sample and Core Library, Bureau of Economic Geology

Funding for the regional assessment of the Frio Formation along the Lower and Middle Texas Gulf Coast was provided by the U.S. Atomic Energy Commission through the Lawrence Livermore Laboratory, Livermore, California, and the Center for Energy Studies of The University of Texas at Austin. Subsequent funding for the study of the remainder of the Frio, Vicksburg, and Wilcox Formations has been provided by the U.S. Energy Research and Development Administration (ERDA), Washington, D.C. Funding for the detailed investigations leading to selection of a test site has also been from ERDA. 
Bebout, D. G. 1976, Subsurface techniques for locating and evaluating geopressured geothermal reservoirs along the Texas Gulf Coast, in Dorfman, M. H., and Deller, R. W., eds., Proceedings, Second geopressured geothermal energy conference: Univ. Texas, Austin, Center for Energy Studies, $44 \mathrm{p}$.

Agagu, O.K., and Dorfman, M. H., 1975, Geothermal resources - Frio Formation, Middle Texas Gulf Coast: Univ. Texas, Austin, Bur. Econ. Geology Geol. Circ. 75-8, 43 p.

Dorfman, M. H., and Agagu, O. K., 1975, Geothermal resources-Frio Formation, South Texas: Univ. Texas, Austin, Bur. Econ. Geology Geol. Circ. 75-1, $36 \mathrm{p}$.

Loucks, R. G., Bosch, S. C., and Dorfman, M. H., 1976, Geothermal resources-Frio Formation, Upper Texas Gulf Coast: Univ. Texas, Austin, Bur. Econ. Geology Geol. Circ. 76-3, $47 \mathrm{p}$.

Bosch, S. C., 1975, Depositional pattern in the growth-faulted Frio Formation (Oligocene) McAllen-Pharr field, South Texas: Univ. Texas, Austin, M.A. thesis, $139 \mathrm{p}$

Boyd, D. R., and Dyer, B. F., 1964, Frio barrier bar system of South Texas: Gulf Coast Assoc. Geol. Socs. Trans., v. 14, p. 309-322.

Brill, J. P., and Beggs, H. D., 1975, Two phase flow in pipes: Univ. Tulsa, Okla.

Bruce, C. H., 1973, Pressured shale and related sediment deformation: Mechanism for development of regional contemporaneous faults: Am. Assoc. Petr. Geologists Bull., v. 57 , p. 878-886.

Campbell, F. F., 1941, Deep correlation reflections near Hoskins Mound Salt Dome: Geophysics, v. 6, p. 259-263.

Casse, J. and Ramey, J. Jr., 1976. The effect of temperature and confining pressure on single phase flow in consolidated rocks, SPE \# 5877 presented at 46th Annual California Regional Meeting of the SPE(AIME) Long Beach, Calif., April, 1976, Soc. Petr. Eng.

Culberson, O. L. and McKetta, J. J., 1951, Phase equilibria in hydrocarbon-water systems III-the solubility of methane in water at pressures to 10,000 psia: Trans. Amer. Inst. Mining Eng., v. 192, p. 223-226.
Dodson, C. R. and Standing, M. B., 1944, Pressure volume-temperature and solubility relations for natural gas-water mixtures: Drill. and Prod. Prac., Amer. Petr. Inst., p. 173-179.

Edwards, M. B., 1976, Growth faults in Upper Triassic deltaic sediments, Svalbard: Am. Assoc. Petr. Geologists Bull., v. 60, p. 341-355.

Farina, John R., 1976, Review well performance-Chocolate Bayou Field; relation deliverability to potential water production rates: Special report, Sneider and Maeckel Associates, Houston, Texas, $25 \mathrm{p}$.

Fisher, W. L., 1969, Facies characterization of Gulf Coast Basin delta systems, with holocene analogues: Gulf Coast Assoc. Geol. Socs. Trans., v. 19, p. $239-$ 261.

Folk, R. L., 1968, Petrology of sedimentary rocks: Hemphill's, Austin, Texas, $170 \mathrm{p}$.

Fowler, W. A., 1970. Pressures, hydrocarbon accumulation, and salinities Chocolate Bayou field, Brazoria County, Texas: Jour. Petr. Tech., v. 22, p. $411-423$

Frazier, D. E., 1974, Depositional-episodes: their relationship to the Quarternary stratigraphic framework in the northwestern portion of the Gulf Basin: Univ. Texas, Austin, Bur. Econ. Geology Geol. Circ. 74-1, 28 p.

Galloway, W. E., 1977, Catahoula Formation of the Texas Coastal Plain - depositional systems, mineralogy, structural development, ground-water flow history, and uranium distribution: Univ. Texas, Austin, Bur. Econ. Geol. Rept. Invest. 87.

Garg, S. K., Pritchett, J. W., Rice, M. H., Riney, T. D., 1977, U.S. Gulf Coast geopressured geothermal reservoir simulation: work performed under U.S. Energy Research and Dev. Adm. contract $E(40-1)-5040$ for the Univ. Texas, Austin.

Grim, R. E., 1962, Applied clay technology: McGraw-Hill Book Co., Inc., New York, N.Y., $422 \mathrm{p}$.

Gustavson, T. C. and Kreitler, C. W., 1976, Geothermal resources of the Texas Gulf Coast-environmental concerns arising from the production and disposal of geothermal waters: Univ. Texas, Austin, Bur. Econ. Geology Geol. Circ. 76-7, $35 \mathrm{p}$. 
Hardin, G. C., Jr,; 1961, Subsurface geology, in Geology of Houston and vicinity, Texas: Houston Geological Society, Academic and Library Committee, p. 21-26.

Horner, D. R., 1951, Pressure build-up in wells, in Proc. Third World Petr. Cong.: E. J. Brill, Leiden II, Ger., p. 503.

House, P. A., Johnson, P. M., and Towse, D. F., 1975, Potential power generation and gas production from Gulf Coast geopressured reservoirs: Lawrence Livermore Laboratory, Univ. Calif., Livermore, $40 \mathrm{p}$.

Hsu, K. J., 1977, Studies of Ventura field, California, II, in Lithology, compaction, and permeability of sands: Am. Assoc: Petr. Geologists Bull., v. 61, p. 169191.

Kehle, R. O. 1971, Geothermal survey of North America: 1971 annual progress report: unpublished report, Research Committee, Am. Assoc. Petr. Geologists, Tulsa, Okla., 31 p.

Knapp, R. M., and Elemo, R. O., 1977, personal communication.

Lindquist, S. J., 1976, Sandstone diagenesis and reservoir quality. Frio Formation (Oligocene), South Texas: Univ. Texas, Austin, MA thesis, $147 \mathrm{p}$.

Matthews, C. S. and Russell, D. G., 1967, Pressure buildup and flow tests in wells, in Henry L. Doherty Monograph Series, v. 1: SPE (AIME), New York, N.Y., p. 147-149.

McLatchie, A. S., Hemstock, R. A., and Young, J. W., 1958, The effective compressibility of reservoir rock and its effect on permeability: SPE Trans. (AIME), v. 213, p. 386-388.
Odeh, A. S. and Jones, L. G., 1965, Pressure drawdown analysis, variablerate case: Trans. SPE (AIME), v. 234, p. $960-964$.

Podio, A. L., Gray, K. E., Isokrari, O. F., Knapp, R. M., Silberberg, I. H., and Thompson, T. W., 1976, Reservoir research and technology, in Proc., Second geopressure geothermal energy conference: Univ. Texas, Austin, Center for Energy Studies, v. 3, pt. 1, p. 54-56.

Rose, W.; 1949, Theoretical generalizations leading to the evaluation of relative permeability: SPE Trans (AIME), v. 179, p. 111-126.

Schmidt, G. W., 1973, Interstitial water composition and geochemistry of deep Gulf Coast shales and sandstones: Am. Assoc. Petr. Geologists Bull., v. 57, p. 321-337.

Seglund, J. A., 1974, Collapse-fault systems of Louisiana Gulf Coast: Am. Assoc. Petr. Geologists Bull., v. 58, p. 2389-2397.

Swanson, R. K., Oetking, P., Osaba, J. S., and Hagens, R. C., 1976, Development of an assessment methodology for geopressured zones of the Upper Gulf Coast based on a study of abnormally pressured gas fields in South Texas: Southwest Research Institute, San Antonio, Texas, ERDA Contract No. $E(11-1)-2687,75 p$. 


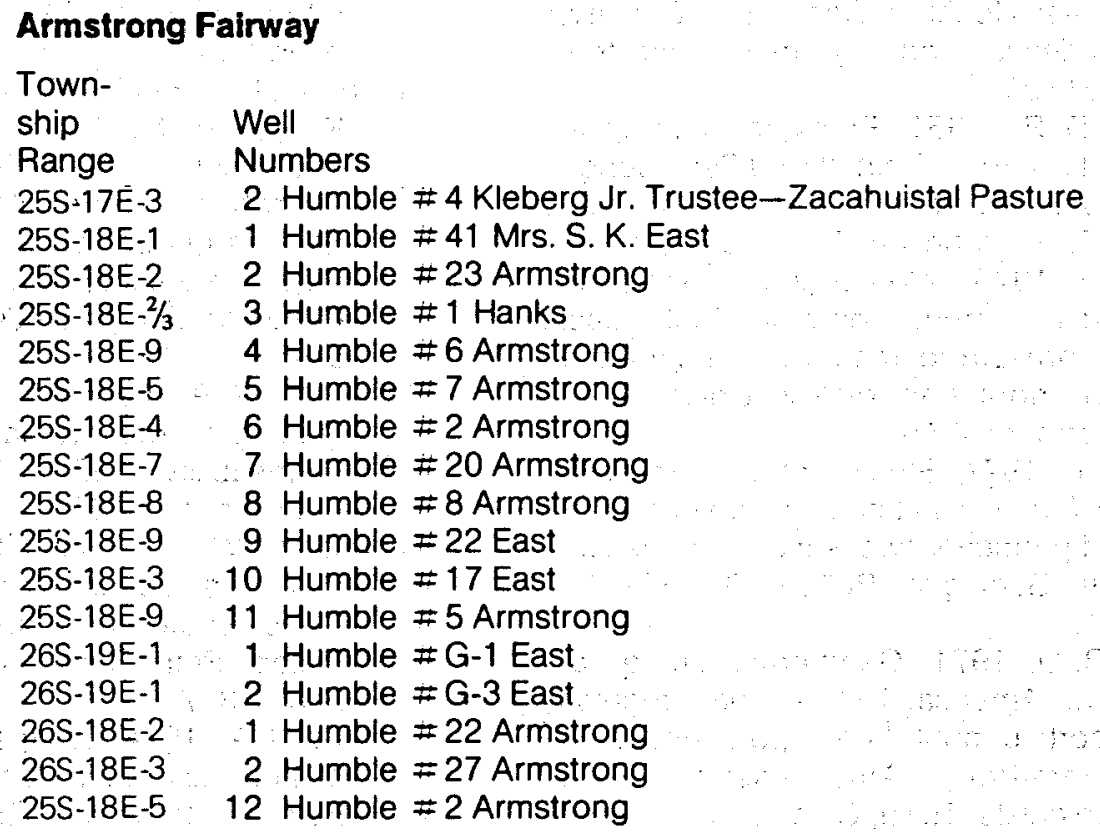

\section{Austin Bayou Prospect}

$5 \mathrm{~S}-39 \mathrm{E}-8$

$5 \mathrm{~S}-39 \mathrm{E}-8$

$5 \mathrm{~S}-39 \mathrm{E}-8$

$5 S-40 E-7$

$5 S-40 E-8$

$5 S-40 E-8$

$5 \mathrm{~S}-40 \mathrm{E}-8$

5 S- $40 \mathrm{E}-9$

$5 S-40 E-9$

6S-37E-6

6S-37E-8

6S-37E-8

$6 \mathrm{~S}-37 \mathrm{E}-8$

$6 S-37 \mathrm{E}-8$

6S-37E-9

6S-37E-9

$6 \mathrm{~S}-38 \mathrm{E}-1$

$6 \mathrm{~S}-38 \mathrm{E}-1$

$6 \mathrm{~S}-38 \mathrm{E}-1$

$6 \mathrm{~S}-38 \mathrm{E}-1$

$6 \mathrm{~S}-38 \mathrm{E}-1$

$6 \mathrm{~S}-38 \mathrm{E}-2$

$6 \mathrm{~S}-38 \mathrm{E}-6$

$6 \mathrm{~S}-38 \mathrm{E}-6$

$6 S-38 E-8$

$6 \mathrm{~S}-38 \mathrm{E}-8$

$6 \mathrm{~S}-39 \mathrm{E}-1$

$6 \mathrm{~S}-39 \mathrm{E}-1$

6S-39E-1

$6 \mathrm{~S}-39 \mathrm{E}-1$

$6 S-39 E-1$
3 Superior Oil Co. $=1$ Conklin

4 Superior Oil \& Pan Am Petr. Corp. 1 Winton Gas Unit

5 Superior Oil \& Pan Am Petr. Corp. $=1$ Winton Gas Unit

12 J. W. Mecom et al. = B-13 Maco Stewart

6 Placid Oil et al. $=1-1 \mathrm{C}$. S. Thompson et al.

7 Placid Oil Co. $=1$ Crane Gas

9 J.W. Mecom $\# 4$ Ervin-Bishop

3 Rowan Oil \& Texas Gulf Prod. Co. $\neq 1$ Corine Scott

$13 \mathrm{H}$. L. Hunt $=1$ R. R. Flaniken

2 Union Texas Petr. Co. $\# 1$ J. T. Garrett

1 Davis Oil Co. \#1 R. J. Lostracco

3 General Crude $\neq 1$ A. K. Lostracco

4 Carlisle Blalock $\neq 1$ L. H. Turner

5 Slick Oil Co. $1 \mathrm{~L}$. Conklin

6 The Texas Co. $1 \mathrm{~S}$. L. Reeves

7 Cooper Petr. Co. $\# 1$ B. W. Turner

1 Brown \& McKenzie, Inc. \#1 Clark Est.

8 Union of Texas Petr. \#1 E. L. Summer

9 North Central $\# 1$ Hubbard

10 Texkan $\# 1 \mathrm{M}$. K. Lorenz

11 Tex. Eastern Trans. Corp. \# 4-1 North Rowan Gas

6 Midland Prod. Corp. 1 E. W. Wissner

5 Ada Oil Co. \#1 M. F. Baugh

7 Pan Am Oil \# 1 Callahan

3 Stanolind Oil \& Gas Co. \#1 S. D. Hawley

4 Stanolind Oil \& Gas Co. \#2 S. D. Hawley

1 The Texas Co. B-1 J. W. Harris

14 M.P.S. Prod. Co. \#1 M. T. Chapman et al.

15 The Texas Co. \#1 Joe Tocker O/A

16 The Texas Co. \#1 W. E. Eggers Gas

18 The Texas Co. \#1 Kainer 
6S-39E-2

$6 S-39 E-2$

6S-39E-2

6S-39E-3

6S-39E-3

6S-39E-3

6S-39E-3

$6 \mathrm{~S}-39 \mathrm{E}-4$

6S-39E-4

6S-39E-5

6S-39E-5

$6 \mathrm{~S}-39 \mathrm{E}-5$

$6 \mathrm{~S}-39 \mathrm{E}-5$

$6 \mathrm{~S}-39 \mathrm{E}-5$

6S-39E-5

6S-39E-5

6S-39E-5

6S-39E-5

6S-39E-6

6S-39E-6

6S-39E-6

6S-39E-6

6S-39E-7

$6 \mathrm{~S}-39 \mathrm{E}-7$

6S-39E-7

6S-39E-7

6S-39E-7

6S-39E-7

6S-39E-7

6S-39E-7

$6 \mathrm{~S}-39 \mathrm{E}-8$

$6 S-39 E-8$

6S-39E-8

6S-39E-8

$6 \mathrm{~S}-40 \mathrm{E}-1$

6S-40E-1

6S-40E-1

$6 \mathrm{~S}-40 \mathrm{E}-2$

6S-40E-2

$6 \mathrm{~S}-40 \mathrm{E}-2$

6S-40E-2

6S-40E-2

6S-40E-3

6S-40E-3

6S-40E-3

6S-40E-3

6S-40E-3

6S-40E-3

6S-40E-4

6S-40E-4

6S-40E-4

$6 S-40 E-4$

6S-40E-4

6S-40E-4

6S-40E-4

6S-40E-4

6S-40E-4

$6 S-40 E-4$
19 Phillips Petr. Co. \# 1 Robnett

35. Ambassador \#1 F. E. Perkins

36 Phillips Petr. Co. \# 1 Kentzelman

29 Burns Trust No. Two \#1 Triangle

30 Burns Trust No. Two \#1 Potter

31 B. B. \& B. \#1 F. Truska

32 Quintana \# 1 Herring

4 General Crude Oil Co. \# 3 Houston Frm.

5 Phillips Petr. Co. \# M-2 Houston Frm.

6 Phillips Petr. Co. \#2-A Schenck

7 Phillips Petr. Co. \# T-1 Houston Frm.

8 Phillips Petr. Co. \#1 Gunderson

20 Phillips Petr. Co. \# S-1 Houston Frm. Dev.

22 Phillips Petr. Co. \#2 Gewil

25 Phillos Petr. Co. \# F-3 Houston Frm:

27 Phillips Petr. Co. \#2 Rekdahl

28 Phillips Petr. Co. \#2 Gunderson

37. Wynn Crosby \#1 Wilson

3 Phillips Petr. Co. \# U-1 Houston

17 Texas Eastern Trans. Corp. \# 1 NANA

21 Phillips Petr. Co. \#A-1 Mcllveine

38 The Texas Go. \#1 J. W. Harris et al.

2 Phillips Petr. Co. \# JJ-I Houston Frm.

9 Phillips Petr. Co. \#FF-1 Houston Frm.

10 Phillips Petr. Co \# 1 Mcllveine

11 Phillips Petr. Co. \# EE-1 Houston Frm.

23 The Superior Oil Co. $\# 1$ Houston Frm. Dev.

24 Phillips Petr. Co. \# Z-1. Houston Frm.

39 Phillips Petr. Co. \# $B$ Youston Frm.

41 Phillips Petr. Co. \#NN Houston Frm.

12 Phillips Petr. Co. \#X-1 Nouston Frm.

13 The Texas Co. \& Ft. Bend Oil Co. $\$ 2$ Houston Frm.

Dev. Co.

26 Monsanto Chem. Co. \#2 Houston Frm.

40 General Crude Oil Co. \# 1 Persimmon Bayou Tract 151

4. Tex. Eastern Trans. Corp. \# 1-1 Hitchcock Gas Unit

5 J.S. Michael \#1 T. A. Newman

19 Placid Oil Co. \# 1 Camp Wallace Co.

1 Hassie Hunt Trust Co. \#1 Ben Sass

6 . Hassie Hunt Trust \& Phillips \# A-1 Brıster

20 Hassie Hunt Trust \# 3 Green et al.

21 Placid Oil Co. \# 1 L. G. Lobit et.al.

22 Hassie Hunt Trust \# 1 S. H. Green et al.

7 Hassie Hunt Trust \# 1-A Tacquard et al.

8 Phillips Petr. Co. \# B-2 Pabst

9 Del Mar Petr., Inc. \#1 J. M. Harris

10 Del Mar Petr., Inc. \# 1 W. N. Zinn

23 Hassie Hunt Trust $\# 2 \mathrm{H}$. Sayko et al.

24 Tex. Eastern Trans. Corp. \# 1-1 N. D. Newton

11. Buttes Gas \& Oil Co. \#2 A. B. Marshall

12 E. L. Cox \# 1 Halls Bayou Ranch

13 Phillips Petr. Co. \#A-1 Christensen

25 General Crude Oil Co. \# 1 Reitmeyer-Brisco

26 Nor-Am Expl. Co. \# 1 Lucille Konzack

27 Buttes Gas \& Oil Co, \# 1 A. B. Marshall

28 Phillips Petr. Co. \# 1 Lauzon

29 E. L. Cox \& R. McFarland \# 1 Terrell

30 Phillips Petr. Co. \# 1 Hulen.

31 General Crude Oil Co. \#1 T. Hulen 
$6 \mathrm{~S}-40 \mathrm{E}-4$

$6 \mathrm{~S}-40 \mathrm{E}-5$

6S-40E-5

6S-40E-5

6S-40E-5

$6 S-40 E-5$

6S-40E-6

$6 \mathrm{~S}-40 \mathrm{E}-7$

6S-40E-7

$6 S-40 E-8$

6S-40E-8

$6 S-40 E-9$

$6 S-40 E-9$

6S-40E-9

7S-36E-7

7S-36E-8

7S-37E- 1

7S-37E-1

7S-37E-1

7S-37E-1

7S-37E-2

7S-37E-2

7S-37E-4

7S-37E-5

7S-37E-5

7S-37E-5

7S-37E-6

7S-37E-7

7S-37E-9

7S-38E-2

7S-38E-2

7S-38E-2

7S-38E-2

7S-38E-3

7S-38E-3

7S-38E-3

7S-38E-4

7S-39E-1

7S-39E-1

7S-39E-1

7S-39E-1

7S-39E-1

7S-39E-1

7S-39E-2

7S-39E-6

7S-39E-6

7S-39E-6

7S-39E-9

7S-40E-1

$7 \mathrm{~S}-40 \mathrm{E}-4$

7S-40E-9

8S-36E-1

8S-36E-1

8S-36E-1

8S-36E-1

8S-36E-2

8S-36E-2

8S-36E-6
39 Sinclair Oil \& Gas Co. \#1 A. B. Marshall

$14 \mathrm{~J}$. W. Mecom \#1 J. A. Roos Trustee

15 Phillips Petr. Co. \#A-2 Tacouard

16 Phillips Petr. Co. \# 3 O'Daniel

32 Phillips Petr. Co. \# A Evans

33 Tex. Eastern Trans. Corp. \# 3 Craig

2 Tex. Eastern Trans. Corp. \#1 S. L. Henck

17. Sun Oil Co. \#1 Wangemann

34 Pure Oil Co. \#1 Houston Frm.

3 Mobil Oil Co. \# 1 Halls Bayou

35 Sun Oil Co. \#1 Craig et al.

18 Buttes Gas \& Oil Co. \# 3 A. B. Marshall

36 Phillips (T. O. Payne) \# 1 Griffith East.

37 Phillips Petr. Co. \# GG-1 Houston

3 Slick Oil $\# 1$ W. B. Munson

2 F. A. Gallery \# A-1 H. C. Munson

5 Royal Resources Corp. \# 1 Minni Warner Mettler Trust

8 Cregg \& Hunt et al. \#1 G. C. Cannon

11 Holmes Drilling Co. \#1 H. Moore

12 Patrick Petr. Co. \#1S. Moller

13 Michael \# 1 Moore

14 Texkan-Slick \# 1 W. N. Moore

1 Monsanto Co. \& Pan Am Petr. Co. \#1 Stasny

2 Humble Oil \& Refg. Co. \# A-2 Lee Oil Unit

10 Cities Services Oil Co. \#1 Murray

18 Davis Oil Co. \#1 Galaznik

3 Pano Tech. Expl. Corp. \# 1 Jaminson

4 Dillard \& Waltermire \#1 J. O. Webb

9 Humble Oil \& Rfg. Co. \# 3 South Angleton G. U.

1 Union of Calif. \# 1 Houston Frm.

2 Humble Oil \& Rfg. Co. \# 1 J. M. Skrabanek

3 Midwest \# 1 Houston Frm.

4 Gulf Oil Corp. \#1 R. W. Vieman

5 Texaco Inc. \#1 S. Tex. Devl. Co. NCT-1

6 Mitchell \#1 Novak

7 M. L. Halbouty \# 1 Otto Schenk et al.

9 Lario Oil \& Gas Co. \& Felmont Oil Corp. \#1 E. D. Bieri

1 Union Oil Co. of Calif. \# 1 Houston Frm.

2 Phillips Petr. \# LL-1 Houston Frm.

3 Midwest Oil Corp. et al. \#1 Houston Frm.

5 Stanolind Oil \& Gas Co. \# D-1 Houston Frm.

7 General Crude Oil Co. \# 1 Martin

9 General Crude Oil Co. \#5 T. Martin Fee

8 General Crude Oil Co. \# 2 Martin

4 Sun Oil Co. \#1 Houston Frm.

6 General Crude Oil Co. \#1 Shell Point

10 General Crude Oil Co. \# 3 Martin

11 Texaco \#1 Hoskins Mound Fee

3 McCulloch Oil Corp. \#1 Labit

1 Phillips Petr. Co. \# BB-1 Houston Frm.

2 Phillips Petr. Co. \# 1 St. Lease 51,000 Blk 32

1 Mobil Oil Co. \#1 St. Retrieve Frm. Tr. 1

5 Mobil Oil Co. \#1 Smith et al.

9 Mobil Oil Co. \# 1 Brock

10 Mobil Oil Co. \#1 Williams

2 Humble \#1 Ward-Byers

8 Austal Oil Co. Inc. \#1 D. C. Bintliff

6 Humble Oil \& Rfg. \#1 Tract 5 
8S-37E-2/3

8S-37E-3

8S-37E-3

8S-37E-3

8S-37E-5

8S-37E-6

8S-37E-9

8S-37E-9

$8 \mathrm{~S}-38 \mathrm{E}-2$

8S-38E-2

8S-38E-7

8S-38E-7

8S-39E-1

8S-39E-2

8S-39E-2

9S-36E-1

9S-37E-1

9S-37E-2

9S-37E-2

9S-37E-3

9S-37E-3

9S-37E-3

9S-37E-3

9S-37E-3
1 Humble \#1 St. Retrieve Frm. \#4

2 Humble Oil \& Rfg. Co. \#1 A. B. Williamson

3 Socony Mobil Corp. \& Texkan Oil Co. \#2-A Retrieve Frm. Tract 2-2

6. Texkan Oil Co. \#1 Retrieve St. Prison Frm.

4 Continental Oil Co. \#1 White Frost

5 Brazos Oil \& Gas Co. \& E. Cockrell Jr. \#1

8 Brazos Oil \& Gas Co. \#1 Clemens St. Frm. Tract 1-A

9 Socony Mobil Oil Co. Trunkline \# $1 \mathrm{H}$. McNeil

5 Texaco, Inc. \#2 Hoskins Mound Fee NCT-1

3 Mobil Oil Corp. \#1 Danby

1 Tenneco Oil Co. \# 1 Am. Fletcher Nat'i Bank

4 Brazos Oil \& Gas Co. \# 1 Henderson

3 Texaco, Inc. \# 1 Tarpon Mound Fee

1 Gulf Oil Corp. \#2 Tex. St. Lease 53034

2 Gulf Oil Corp. \# 1 Tex. St. Lease 53034

1 Mobil Oil Co. \# 3 Tex. St. Lease 49016 Tract 7

4 Dow \# 1 Freeport Sulphur

5 Gulf Oil Corp. \#1 L. B. Hervey

6 Gulf Oil Corp. \# 1-1 Jones Creek

7 J. E. Gulbault \# 1 J. H. Dingle

8 Socony Mobil Oil Co. \& Trunkline \# 1. J. H. Dingle

9 Gulf Oil Corp. \#1 S. S. Perry

10 Gulf Oil Corp. \#2 S. S. Perry

11 Gulf Oil Corp. \# 1 Caldral

\section{Corpus Christi Fairway}

17S-22E-1

$17 \mathrm{~S}-22 \mathrm{E}-2$

$17 \mathrm{~S}-22 \mathrm{E}-3$

$17 \mathrm{~S}-22 \mathrm{E}-4$

$17 \mathrm{~S}-22 \mathrm{E}-6$

$17 \mathrm{~S}-22 \mathrm{E}-7$

$17 \mathrm{~S}-22 \mathrm{E}-8$

17S-22E-9

$17 \mathrm{~S}-22 \mathrm{E}-1$

17S-23E-1

17S-23E-1

17S-23E-3

17S-23E-4

17S-23E-5

$17 \mathrm{~S}-23 \mathrm{E}-8$

17S-23E-8

17S-23E-8

17S-24E-1

$17 \mathrm{~S}-24 \mathrm{E}-2$

$17 \mathrm{~S}-24 \mathrm{E}-3$

$17 \mathrm{~S}-24 \mathrm{E}-5$

17S-24E-6

17S-24E-8

17S-24E-9

17S-24E-9

18S-22E-1

18S-22E-1

$18 \mathrm{~S}-22 \mathrm{E}-2$

$18 \mathrm{~S}-22 \mathrm{E}-3$

$18 \mathrm{~S}-22 \mathrm{E}-3$

18S-22E-6
1 Hamon \#2 Harvey

2 Hamon \# 1 Dillon

4 Royal \# 1 Schmidt

5 Lawbar \#1 Hunt-Dugat

8 Union Texas \# 1 Jones

9 American Petrofina \#1 Green Estates

10 The Texas Co. \# 1 Green Estate

11 Republic \& Forest \#1 Florerke

12. Conroe, Feldman \& Del Mar \# 1 Hunt

1 Pennzoil \#1 Grant

2 Wagner (Bass) \# 1 Atlantic-Porterfield Est.

4. Pan Am \# 1 Bakers Mortage

5 Hamon \& Sinclair \# 1 Guettler

6 Tenneco \# 1 McCampbell

8 Midwest \# 1-A McCampbell

7. Union of California \# 1 Coward

9 Midwest \# 5 McCampbell

1- Amerada \# 1 St. Tr. 198 " G".

2 Midwest St. Tr. 218

3 Halbouty \#1 Hepworth

4 Cities Service \# 1-B St. Tr. 260

5 Richardson \& Bass \#1 St. Tr. 264

6 Sunray \# 1 St. Tr. 258

7 Getty \#1 St. Tr. 275

8 Shell \#1 St. Tr. 277

10 Cities Service \#5 St. Tr. 9

13 Cities Service \#1 St. Tr. 15

2 British American \#1 St. Tr. 12

16 Cities Service \#1 St. Tr. 40

15 Forest \& Mobil \# 7 St. Tr. 786

18 Cities Service \#1 St. Tr. 21 
18S-22E-7

18S-22E-8

18S-22E-8

18S-22E-8

18S-22E-9

18S-23E-1

18S-23E-3

18S-23E-4

18S-23E-6

18S-23E-6

18S-23E-6

18S-23E-9

18S-24E-3

19S-22E-4

19S-22E-7

19S-22E-9

19S-22E-9

19S-23E-1

19S-23E-2

19S-23E-3

19S-23E-3

19S-23E-4

19S-23E-7

19S-23E-7

19S-23E-9

19S-24E-3

19S-24E-4

19S-24E-4

19S-24E-5

19S-24E-5

19S-24E-7

19S-24E-9
4 Atlantic Richfield $=1$ St. Tr. 34

6 Atlantic Refining $=1$ St. Tr. 36

7 Gulf $\# 2$ St. Tr. 47

8 Cities Service \& Sunray $=1$ St. Tr. 52

9 Cities Service 1-B St. Tr. 72

1 King Resources $\neq 1$ St. Tr. 336

2 Arnold D. Morgan $=1-A$ Welder

8 Renwar \# 1 Hogg Estate

5 Shell $\neq 1$ St. Tr. 349

10 Shell 4 St. Tr. 392

11 Shell 1 St. Tr. 346

13 Atlantic Richfield \& Tidewater $=1$ St. Tr. 471

1 McMoran $=2$ St. Tr. 312

2 Atlantic 1 Pearce

23 Humble $=4$ " $F$ " St. Tr. BI

4 J. P. Driscoll et al. $=1$ Smith et al.

5 Marion $=1$ Peterson

1 Atlantic Richfield $=1$ St. Tr. 432

2 Tenneco $=1$ St. Tr. 458

12 Atlantic Richfield $=4$ St. Tr. 470

9 Cities Service $=1$ St. Tr. 84

4 Getty $=1$ St. Tr. 41

7 Shell $=1$ St. Tr. 899

6 Cities Service $=1$ St. Tr. 773

8 Humble $=1$ St. Tr. 52

1 Sun \& Seaboard $=1$ St. Tr. 882

5 Shell $=1$ St. Tr. 896

3 Shell $\# 1$ St. Tr. 891

8 Humble $=1$ St. Tr. 772

2 Gulf $=1$-B St. Tr. 772

6 Union of California $=1$ St. Tr. $775-\mathrm{L}$

7 Zapata $=1$ St. Tr. 773-L

\section{Matagorda Fairway}

10S-34E-8

Magnolia $=1$ Le Tulle

$10 \mathrm{~S}-34 \mathrm{E}-8$

Falcon Seaboard $=1$ Le Tulle

10S-34E-9

10S-34E-9

10S-34E-9

Falcon Seaboard $=A-1$ Baer Ranch

Falcon Seaboard $=A-3$ Baer Ranch

11S-34E-3

Falcon Seaboard $=A-4$ Baer Ranch

$11 \mathrm{~S}-34 \mathrm{E}-3$

$11 \mathrm{~S}-34 \mathrm{E}-3$

$11 \mathrm{~S}-34 \mathrm{E}-3$

Falcon Seaboard $=A-2$ Baer Ranch

Falcon Seaboard $=$ A-5 Baer Ranch

Falcon Seaboard $=$ A-5 Baer Ranch

11S-34E-3

Ethyl = 1 Baer Ranch

Ethyl $=1-A$ Baer Ranch 